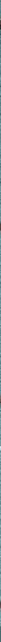

\title{
BETWEEN \\ CONSTANTINOPLE, \\ THE PAPACY AND \\ THE CALIPHATE
}

THE MELKITE CHURCH IN THE

ISLAMICATE WORLD, 634-969

Krzysztof Kościelniak

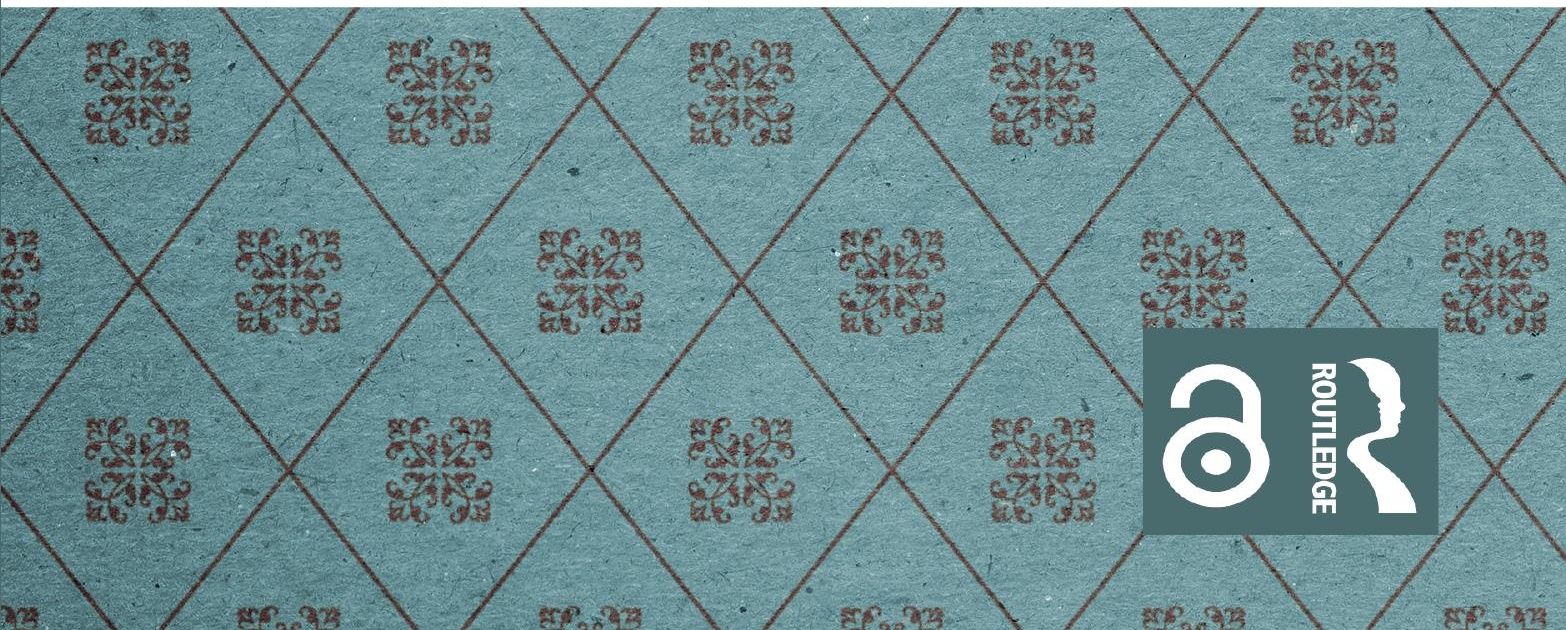




\section{Between Constantinople, the Papacy and the Caliphate}

This volume examines the Melkite Church from the Arab invasion of Syria in 634 until 969. The Melkite Patriarchates were established in Antioch, Jerusalem, and Alexandria and, following the Arab campaigns in Syria and Egypt, they all came under the new Muslim state. Over the next decades the Melkite church underwent a process of gradual marginalization, moving from the privileged position of the state confession to becoming one of the religious minorities of the Caliphate. This transition took place in the context of theological and political interactions with the Byzantine Empire, the Patriarchate of Constantinople, the Papacy, and, over time, with the reborn Roman Empire in the West. Exploring the various processes within the Melkite church this volume also examines Caliphate-Byzantine interactions, the cultural and religious influences of Constantinople, the synthesis of Greek, Arab, and Syriac elements, the process of Arabization of communities, and Melkite relations with distant Rome.

Krzysztof Kościelniak is Professor of the History of the Middle East, Jagiellonian University, Krakow, Poland. 


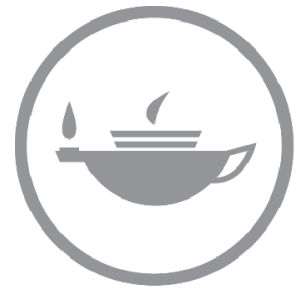

Taylor \& Francis
Taylor \& Francis Group http://taylorandfrancis.com 


\section{Between Constantinople, the Papacy and the Caliphate}

The Melkite Church in the Islamicate World, 634-969

Krzysztof Kościelniak 
First published 2022

by Routledge

4 Park Square, Milton Park, Abingdon, Oxon OX14 4RN

and by Routledge

605 Third Avenue, New York, NY 10158

Routledge is an imprint of the Taylor \& Francis Group, an informa business

(C) 2022 Krzysztof Kościelniak

The right of Krzysztof Kościelniak to be identified as author of this work has been asserted in accordance with sections 77 and 78 of the Copyright, Designs and Patents Act 1988.

The Open Access version of this book, available at www.taylorfrancis.com, has been made available under a Creative Commons Attribution-Non Commercial-No Derivatives 4.0 license.

Trademark notice: Product or corporate names may be trademarks or registered trademarks, and are used only for identification and explanation without intent to infringe.

British Library Cataloguing-in-Publication Data

A catalogue record for this book is available from the British Library

Library of Congress Cataloguing-in-Publication Data

Names: Kościelniak, Krzysztof, author.

Title: Between Constantinople, the papacy and the caliphate : the Melkite Church in the Islamicate world, 634-969 /

Krzysztof Kościelniak.

Description: Abingdon, Oxon ; New York : Routledge, 2022. | Includes bibliographical references and index. |

Identifiers: LCCN 2021057727 (print) | LCCN 2021057728 (ebook)

Subjects: LCSH: Catholic Church. Patriarchate of Antioch (Melchite) | Constantinople (Ecumenical patriarchate) | Catholic Church--Relations--Islam. | Christianity and other religions--Islam. | Byzantine Empire--Relations.

Classification: LCC BX4711.322 .K67 2022 (print) | LCC BX4711.322 (ebook) | DDC 275.6/02--dc23/eng/20220124

LC record available at https://lccn.loc.gov/2021057727

LC ebook record available at https://lccn.loc.gov/2021057728

ISBN: 978-1-032-18132-5 (hbk)

ISBN: 978-1-032-18133-2 (pbk)

ISBN: 978-1-003-25300-6 (ebk)

DOI: $10.4324 / 9781003253006$

Typeset in Times New Roman

by MPS Limited, Dehradun 


\section{Contents}

List of Figures viii

List of Maps ix

1 Introduction 1

1.1 Explanations related to the scope of research 2

1.1.1 The context of Muslim, Byzantine, and Western interactions 5

1.2 Case studies and primary and secondary sources 7

2 The development of the Melkite Church until the Arab conquests

2.1 The genesis of the Melkite Church 19

2.1.1 The etymology, meaning, and history of the name "Melkites" 20

2.1.1.1 The "Melkites" and the Roman Catholic Church 22

2.1.2 The place of the Melkite rite among oriental liturgies 23

2.2 The condition of the Melkite Church until the Arab conquests 26

2.2.1 The patriarchate of Antioch 27

2.2.2 The patriarchate of Alexandria 39

2.2.3 The patriarchate of Jerusalem 45

3 The situation of the Melkite Church in the first centuries of Islam (634-750)

3.1 The Melkite Church and the Arab conquests 50 
3.1.1 The Melkites and the defeat of Byzantium in Syria and Palestine 51

3.1.2 The fall of Byzantine Egypt and uncoordinated Melkite interactions 56

3.2 New rules of functioning of the Melkite patriarchates 59

3.2.1 Political ramifications for the Melkites and other Christian denominations 59

3.2.2 Ambivalence: two types of treatment of the Melkites 62

3.2.3 Negotiation of theories with practice: theological and legal conditions of Melkite existence 67

3.2.4 Fiscalism as the engine of Islamizing Christians? 72

3.2.5 Restrictions on the functioning of Melkites in the public space 73

3.3 The condition of the Melkite communities and institutions 75

3.3.1 The patriarchate of Antioch 75

3.3.2 The patriarchate of Alexandria 85

3.3.3 The patriarchate of Jerusalem 91

3.4 Melkite monasteries and theology 95

3.4.1 The condition of Melkite monasteries 95

3.4.2 Melkite "neo-martyrs" and theology in the context of Early Christian-Muslim polemics 102

3.4.3 The Melkite communities in Persia and Central Asia 109

3.4.4 Sabaites - the Melkites in Rome? 112

4 Melkites in the centralized and disintegrating Abbāsid Caliphate, 750-969

4.1 The Abbāsid sine wave: double standards of the treatment of Christians 115

4.2 The Melkite communities in a new crucible of interaction 121

4.2.1 The patriarchate of Antioch 121

4.2.2 The patriarchate of Alexandria 130

4.2.3 The patriarchate of Jerusalem 133

4.2.4 Melkites east of the Euphrates 139 
4.3 Melkite monasticism and literature 141

4.3.1 The condition of the Melkite monasteries 141

4.3.2 Between Greek and Arabic: Melkite theology and historiography 144

4.3.3 Melkite-Muslim polemics and public discussions 152

5 Conclusions

5.1 The "Starting Point" 634-the legacy of controversy 160

5.2 The early Islamic state and Umayyad period of Melkite-Muslim interaction, 634-750 160

5.3 The Melkite patriarchates in the Abbasid Caliphate, 750-969 163

6 List of Melkite patriarchs, 634-969

6.1 Patriarchs of Antioch 167

6.2 Patriarchs of Alexandria 168

6.3 Patriarchs of Jerusalem 168

Bibliography

170

Index of Geographical Names $\quad 212$

Index of Persons

216 


\section{Figures}

3.1 The remains of the magnificent Melkite St Sergius cathedral in Sergiopolis (today Resafa).

(C) Kościelniak Krzysztof

3.2 Umayyad Mosque in Damascus - the former Melkite Cathedral of St John the Baptist.

(C) Kościelniak Krzysztof

3.3 Fragment of the walls of the Umayyad mosque in Damascus, in which the local Christians recognize the damaged image of Jesus.

(C) Kościelniak Krzysztof

3.4 Monastery complex of Saint Simeon Stylites (Qal'at Sim'ān): basilica. (C) Kościelniak Krzysztof

4.1 Ruins of the church in Bosra.

(C) Kościelniak Krzysztof

4.2 Basilica of St Sergius in Sergiopolis_-Rușāfa.

(C) Kościelniak Krzysztof

4.3 Part of the Simeon Stylites Basilica.

(C) Kościelniak Krzysztof 


\section{Maps}

2.1 Pillar of the Jerusalem patriarchate: the most important monasteries in the Palestinian desert between Jerusalem and the Dead Sea

2.2 Patriarchates after the Council of Chalcedon (451)

3.1 The patriarchate of Antioch according to Notitia of Anastasius I

4.1 Byzantine-Arab border around 960 


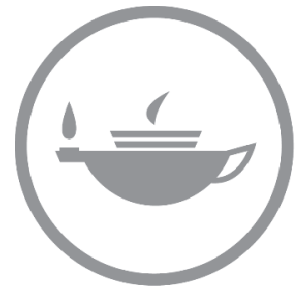

Taylor \& Francis
Taylor \& Francis Group http://taylorandfrancis.com 


\section{Introduction}

For many reasons, the history of the Melkite Church in the Middle Ages deserves a special study. First, this Church in Syria and Palestine gathered the vast majority of Christians in this region. Second, the Melkites were the representatives of Chalcedonian Christology who had relations with Constantinople and Rome as "Catholic" communities (in the sense of broadly defined orthodoxy). Third, until the Arab invasion of Syria (i.e. until 634), the Melkites tried several times, with the support of Byzantium, by more or less effective methods, to bring about a reconciliation of the "Monophysite" and "Nestorian" communities conflicted with them. Fourth, the unique position of the Melkites means that they cannot be synonymous with "Greek Orthodox" (Monferrer-Sala 2012: 445). Nevertheless, these communities have often been influenced by the Patriarchate of Constantinople and the Greek liturgy. Perhaps for this reason some historians equate the Melkites with the Greek Orthodox Church (Kilpatrick 2017: 222; 2019: 33-61). This monograph does not follow such identification. In fact, three Melkite patriarchates were simply "Chalcedonian churches" on specific intercultural crossroads. Finally, as a result of the ties with the Byzantine emperor, the Melkite communities suffered the most under Arab rule, as Muslims constantly suspected them of spying and favouring Constantinople.

Without a hint of exaggeration, the history of the Melkite Church of this period reflects most Muslim-Christian and intra-Christian problems in the Middle East and Central Asia, such as the caliphate-Byzantine interactions, the overwhelming cultural and religious influences of Constantinople, the synthesis of Greek, Arab and Syriac elements, processes of Arabization of communities, literary involvement, inter-confessional rivalries, religious and political persecutions, and relations with distant Rome. That is why Melkite communities in the complex reality of the mediaeval Middle East are worth exploring as a special example of multilateral acculturation and interaction.
Highly interactive position of the Melkites 


\section{Introduction}

\subsection{Explanations related to the scope of research}

Explanation of the title

\footnotetext{
"Nestorianism" and "Monophysitism" "common names" or "inappropriate labels"?
}

Among the many methodological and substantive issues that are discussed in this introduction, we should start with the explanations regarding the title of the work, Between Constantinople, the Papacy and the Caliphate: The Melkite Church in the Islamicate World, 634-969.

The key term "Melkite Church" refers to the communities of Antioch, Jerusalem, and Alexandria, which, in terms of traditional Byzantine influences, had a partial, nominal relationship with the emperor, but due to separation from Constantinople, were more or less independent in the Muslim world. More detailed considerations on the origin and complexity of the term "Melkites" is provided in Section 2.1.1. It should only be mentioned here that the case of the Melkites is a specific, one-of-a-kind Chalcedonian orthodoxy encompassing Greek, Arab, and Syriac cultures, which became Semitic Orthodoxy with time. That is why Maḥbūb b. Qunsțanțīn al-Mambiğī (died 945) described the Melkites as "Christians amongst the Arabs" al-nasārā min al-'arab or "Arabs who wrote in Greek"-'āmmat al'arab allad̄ina kānū bi-l-Ša'm wa-Süriyā kānat hutūtuhum bi-lyūnāniyyah (Agapius 1910: 457, 498).

Discussing the term "Melkites," one cannot lose sight of the "common names" of other Christian groups created in the time of Christological disputes, such as "Jacobites" or al-ya qübiyyah (Agapius 1910: 458-460) and "Nestorians" or Nasturīyūn. Contemporary scholars are particularly critical of adopting a polemical attitude, especially in works with scientific ambition, because there is no single unified perspective of orthodoxy and heterdoxy in Christianity. This is especially inadequate in the context of contemporary dialogue. Names such as "Jacobite Church" or "Nestorian Church" are more and more often perceived by researchers as "both inappropriate and misleading" (Brock 1996: 23). In fact, both names were coined by the Melkites. The name "Jacobites" in Melkite society traditionally referred to the followers of the tradition of Jacob Baradaeus (died 578). In turn, the Melkites branded members of the Church of the East as "Nestorians" on account of its refusal to anathematize Patriarch Nestorius (c. 386-450).

If these terms appear in this book they are certainly not used as "inappropriate labels." They also have nothing to do with the "stigmatisation" of other non-Chalcedonian Christian denominations. Nevertheless, an attempt to use the modern nomenclature of non-Chalcedonian communities such as "the Syrian Orthodox Church," "Syriac Orthodox patriarchate of Antioch and All the East," "Holy Apostolic Catholic Assyrian Church of the East," etc. in a book on the Middle Ages seems somewhat awkward, not because of a lack of an ecumenical attitude. Quite simply, the 
vocabulary of these churches has evolved. There are a number of synonyms that could be confusing.

Still, in the period of Melkite history under analysis, these names functioned as contextual, specific mediaeval "proper names" (although built on prejudices) and appear as such in Melkite sources. So they are used in quotation marks as the standard designation for these two ancient oriental communities, without any polemical undertones. On the other hand, it is very interesting that the name "Melkites" coined by their "monophysical" opponents was accepted by the Melkites themselves as a proper name.

It seems that all rehabilitation positive shifts in the connotations of some names, and above all, removing prejudices, overinterpretation or even distortions means more than just removing historical names - especially when the terms "Nestorian" or "Monophysite" are used in quotation marks as evidence of reserve against old meanings. For example, in referring to the so-called "Nestorianism" or "Monophysitism," it seems to be more important to no longer describe them as heresies but rather as two possible interpretations. Much more vital is the recognition that the adherents of "Nestorian" interpretation did not tear the hypostatic union apart but only emphasized the personal unity of Christ. Much more crucial is the indisputability of the Anaphora of the Apostles Addai and Mari. And it is much more fundamental to understand where the controversy came from and how to correct its negative effects (e.g. misapprehensions arise from different construals of the terms of East Syriac theological thought. The Christology of the Church of the East uses the term kyana or "nature," which in fact is the equivalent

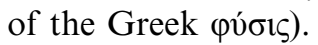

Speaking of the delicate issue of terminology in the era of Christological disputes, the problematic adjective "Catholic" appears. Most generally, "Catholic" has two essential meanings. In late antiquity, it was applied to the "Christian" church, which is (or at least was once) seen (by most Christians) as the one "body" of all believers (and hence "universal"). With time, when such a loosely understood "Catholicity" encountered the divisions, the adjective "Catholic" itself became the name of one of the denominations of Christianity. In other words, "Catholic" is associated with broadly defined orthodoxy or it is related to the historic doctrine and practice of the Western Church. From this first point of view, the definition of the Melkite communities as "Catholic" is perfectly appropriate and ecumenical. Nevertheless, the reason behind the confusion is that all of the three main branches of Christianity in the East (the Eastern Orthodox Church, the Oriental Orthodox Church, and the Church of the East) have always identified themselves as "Catholic." Moreover, they have continued to consider

The problematic adjective "Catholic" 


\section{Introduction}

themselves uniquely orthodox and Catholic. Nevertheless, in the era of Christological controversies, this fundamental agreement between Rome, Constantinople, and the Melkites excluded the followers of "Nestorianism" and "Monophysitism" from the framework of "Catholicism." The contemporary dialogue has shown how many simplifications and reductive perspectives there were. All this combined with the contemporary tendency to reduce the term "Catholic" only to the Roman Church explains why the term tends to be rather restricted or dropped altogether.

Cultural and religious spaces of Melkite patriarchates
Melkite patriarchates of Antioch, Jerusalem, and Alexandria functioned in three main cultural spaces. The Greek and Syriac elements dominated in the first two patriarchates, while the Greek and probably Coptic elements prevailed in Alexandria. Scholars, however, due to lack of sufficient sources, have a problem establishing to what extent the Coptic Melkite rite existed before the 5th century. Anyway, it was the Copts who stopped identifying with the Melkites at the time when the term "Melkites" itself was first coined. For this reason, the book does not deal with the phenomenon of the Arabized Copts, which was a process parallel to the Arabization of the Greeks and Syriac Christians. Hence, in terms of cultural interaction within the Melkite Church, the most visible features were the Greek and Syriac elements, which were Arabized after the Muslim conquests. So, when it comes to Syrians at this period, we mainly mean so-called Syriac Christians, that is, those who were related to the Aramaic elements before they started using Levantine Arabic.

The title of this monograph uses the term "the Islamicate world." The terminological distinction between "Islamic" or "Muslim" world and "Islamicate" world is that the latter adjective refers to regions nominally ruled by Muslims but still with a Christian majority. The terms "Islamic" or "Muslim" are restricted to Islam in the proper, religious sense. Thus, culturally speaking, the discussed period in the Middle East (634-969) was not a purely Islamic "world" because the most diverse interactions created a complex, pluralistic culture of the region with, for example, distinct Melkite (as well as "Nestorian," "Monophysical," Jewish, etc.) features. This clarification is very important because the Melkites (like other Christians) at this time were affected by Islamization. This phenomenon took various courses and varied over time. Generally speaking, these centuries saw the systematic change of the religious landscape of the Middle East.

Another problem is that sometimes in the eyes of the "Monophysites" all the inhabitants of the Byzantine Empire were Melkites. Moreover, Melkites quite often emigrated from the Middle East. Thus, according to the title, the reader will read about the history of the Chalcedonian Orthodoxy patriarchates of the East, which-under the Muslim 
rule-were under the strong influence of Arab culture. The work, therefore, presents the history of the Melkites cultivating their Greek, Syriac, and Arab heritage, affected by both Hellenization and Arabization, situated at the crossroads of the caliphate and Byzantineand relatively often Western-influences.

Next, it should be explained why the period 634-969 of the history of the Melkite Church was chosen. These dates were not selected by chance. They mark the first part of the "Islamic Golden Age." It is true that this age is not clearly indicated. For some, it selecting the period 634-969 was the period of the establishment of the first Islamic state from 622 to the siege of Baghdad in 1258. According to others, the Islamic Golden Age refers to the time between the reign of Hārūn ar-Rašīd (786-809) and 1492 with the completion of the Christian Reconquista of the Emirate of Granada. When accepting the first option, it is worth remembering that the Melkites were incorporated into the Muslim world in 634 (hence the initial time period). The year 969 marks the end of the splendour of the Abbasid caliphate with the conquest of Egypt and then Palestine by the Shi'ite Fatimids. Thus, the Melkite patriarchates of Alexandria and Jerusalem found themselves outside the symbolic power of the Sunni caliph of Baghdad. The year 969 is also the date when Antioch was recaptured by Byzantium. Until 1084, significant areas of the Melkite patriarchate of Antioch were subject to Constantinople. Both dates are important points of reference in the history of the Melkites. The Arab conquest of Syria started the process of destruction and degradation of Byzantine culture in the Middle East. In turn, the arrival of the Fatimides started a style of government and relations between Constantinople and the Christians, which was different from that which took place during the times of politically pluralist Arab domination. In turn, after 969, the Melkite patriarchate of Antioch found a living continuation in a new Byzantine form. Since 634, Antioch, Alexandria, and Jerusalem passed from hand to hand between various Muslim states. Only the capture of these centres by Sultan Selim I (1512-1520), the founder of the Ottoman Empire, during the war campaign in 1516-1517, started a new era for Syria, Palestine, and Egypt, and thus for the Melkite Church.

\subsubsection{The context of Muslim, Byzantine, and Western interactions}

The Melkites were closer to Byzantium than to Rome. It is worth emphasizing, however, that the Melkite patriarchates operated relatively independently in their contact with Constantinople, and much less frequently with Rome. One can even speak more of a 
partnership if one takes into account the practice of Byzantine Caesaropapism (the relationship between emperors and the patriarchs of Constantinople) or later Roman centralism (the relationship between the papacy and Uniate patriarchs). Although Melkite contact with Western Christianity was less frequent, it was nevertheless significant. These were cases of an open approach of individual churches towards each other. It is worth recalling at least the community of Melkite migrants from Palestine to Rome (Sabaites), the involvement of some popes in the disputes with support of Monotheletism, Syrian popes in Rome after the Muslim conquests such as John V (685-686), Sergius I (786-701), Constantine (708-715), and Gregory III (731-741), or the involvement of Charlemagne in Eastern politics.

It is this weave of interactions between the caliphate, Byzantium, and Rome that explains part of the title Between Constantinople, the Papacy and the Caliphate.

Type of presentation The work is not focussed only on chronicling the facts from the history of the Melkite Church, which if detached from numerous contexts may be incomprehensible to the reader. The author tries to synchronize the events of the general history of the region and the processes taking place in the Islamic world while simultaneously presenting the history of the Melkites. A natural consequence of discussing these "contexts" is the inclusion of some extracts from the history of the region and interpretations of historians on particular historical realities. Of course, they are strongly related to the condition of Melkite communities. All this is done in order to observe how the Melkites adapt to the dynamically changing reality of the Middle East. It is difficult for the author to judge to what extent this book will meet the reader's expectations in this regard.

The purpose of this book is to show the history of the Melkite Church in one of its most fateful periods. The synthesis presented herein, like other publications of this type, was created on the basis of historical facts (i.e. the analysis of sources) and historiographic facts (i.e. findings that are the product of the critical research of historians). Thus, by using sources and older and newer studies on the history of the Melkites, the author tries to present the history of the Melkite Church in a comprehensive manner, of course taking into account the human handicap of synthesizing such extensive thematic ranges. Syntheses are always burdened with such a controversial selection of representative facts for the explanation of particular phenomena or trends. The synthesis cannot represent the entire range of details about the mediaeval interactions of the Melkite Church. Therefore, the criteria for selection of some facts and topics can also be discussed endlessly. 


\subsection{Case studies and primary and secondary sources}

Here two problems are addressed: the relatively small number of Some critical remarks Melkite sources and of topoi in mediaeval texts. Contemporary critical research into both mediaeval Christian and Muslim historiography focusses on the capture of various topoi and later interpolations and contamination. History is built on facts and interpretations. Topoi research is largely about discovering the meanings of certain realities for a particular community. Paradoxically, in many cases what is true for some historians may be a legend for others. The question remains as to what extent the facts of the epoch's events can be recreated and whether the facts were always secondary to the topoi. Even if some authors see many topoi before the facts in mediaeval chronicles and other sources, they eventually return over and over again to reinterpreting these texts for want of others. It is just that the resource base is seriously limited.

In this situation, it requires numerous searches in various Christian and Muslim sources, sometimes even painstaking work to find scattered crumbs of information on various topics related to the political, religious, and church situation of the Melkites. The paradox in researching the history of the mediaeval Melkite Church is that despite the fact that the works of three Arabic-speaking Melkite historians have reached us, the history of this Church is much less known to us than the fate of the Syriac Orthodox Church (called the "Jacobite Church" in the mediaeval period) or the "Nestorians" (Troupeau 1999: 325). This is revealed, for example, by the difficulties in recreating the chronology of the patriarchs of all three Melkite patriarchates: Antioch, Jerusalem, and Alexandria (Grumel 1958: 442-444, 446-448, 451-452; 1962: 264-267; Maséro 1923: 361-379; Karalevskij 1924: 697-700; Chaine 1925: 254-256; Fortescue 1910: 355-364; Dowling 1913: 164-177). Without a shred of exaggeration, it can be said that our knowledge of the history of this community is largely fragmented, and the patriarchal lists contain many blank spots, which is simply unthinkable for the papacy in the same period.

We have a great deal of studies and detailed research on the Melkites. However, a certain insufficiency is felt in this context as well. The classic, unfinished history of the Melkite Church, dating back more than a hundred years, was written by Cyrille Karalevskij (Кирилл Королевский), who was in fact, Jean François Joseph Charon (1878-1959), a French Catholic clergyman of the oriental rite (Karalevskij 1910-1911). In turn, the article by this author, entitled Antioch in DHGE (Karalevskij 1924: 563-703), is quite an outdated study, though there are parts that inspire reflection. Back to the history of Karalevskij: the first volume of this work is devoted to the period from the 5th to the 19th centuries; the second volume covers

The state of research 


\section{Introduction}

the history from 1831 to about 1905; and the third volume focusses on the institutions of the Melkite Church and contains an abundant bibliography on the Melkites. Nevertheless, this research is criticized today and is sometimes referred to as "unbelievably shoddy and polemical" history (Samn 2010).

A more recent work on the Melkites is the publication written by a Melkite-Catholic Bishop Agnātiyus Dīk (1926-2013) from the perspective of Greek Catholics (Dick 1994, English version: Dick 2004). Many topics were covered in this 233-page publication, such as the division within the Melkite Church, the difficulties suffered under Islamic rule, the historical development of the doctrine and Melkite iconography, architecture, and writers (seven chapters: history [1], doctrine [2], an anthology of Melkite literature [3], sacred art [4], spiritual life [5], community profile [6], and ecclesial organization [7]). Due to its introductory nature, however, the book does not strictly cover the mediaeval period.

Much information on the Melkite Church from 634 to 1515 is outlined by Yūsuf Nașrallāh (1911-1993) and Rašì̄d Ḥaddād (born 1929) in their monumental study of the Melkite literature (Nasrallah, Haddad 1979; 1996a, 1996b). For a better understanding of the MuslimMelkite mediaeval interactions, it is necessary to take into account the Melkites' view of the Muslim-Melkite relations, such as Al- 'Alāqāt almasīhìya al-islāmìya fì Sūrīya 'abr al-tārīh (Dīk 2013) or Muğādalat Abì-Qurra ma'a al-mutakallimīn al-Muslimīn fì mağlis al-Halïfa alMa'mūn (Dīk 1999) by the aforementioned Ag̀nātịus Dīk (1926-). In turn, the work of the Archbishop of Athens and All Greece,

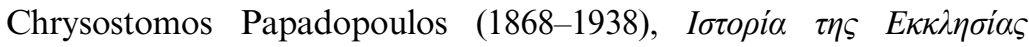
$A \lambda \varepsilon \xi \dot{\alpha}^{\alpha} v \delta \rho \varepsilon l \alpha \varsigma(62-1934)$ is also very helpful, although it is not free from controversial elements when it comes to the Coptic vision of the history of the patriarchate of Alexandria (Papadopoulos 2009).

Many fresh and original interpretations and discussions of the condition of Melkites in the Middle Ages have provided us quite a lot of insightful research in recent decades. These studies particularly reveal, in a particular way, the problems of reading mediaeval Christian and Muslim sources together with determining the scope of their topoi and facts. A lot of interesting research on the Melkites in the period 634-750 was carried out by Sidney Harrison Griffith (1938-). The author focusses primarily on the Melkite contribution to the shaping of Arab orthodoxy in the context of interreligious polemics (Griffith 2001: 9-55; 2006: 174-204; 2013: 413-443); Mathilde Boudier describes the condition of the Melkite Church in the 9th century in Syria by analysing unpublished documents on the conflict between Metropolitan Bishop David of Damascus and Simeon of Antioch (Boudier 2018: 45-80); Vassilios Christides examines the decline of the Melkite Church in early Islamic Egypt 
(Christides 2016: 1-11; 2017: 1-13); Hilary Kilpatrick (1946-) presents Melkite monasteries in the eyes of Muslims from the Diyārāt books, which are valuable sources for research of Arab Christianity during the Abbasid period (Kilpatrick 2003: 19-37). Phil Booth analyses in detail the last years of Cyrus, patriarch of Alexandria (Booth 2016: 509-558); Juan Signes Codoñer (1964-) looks at the Melkites' attitude to icon worship during the Iconoclastic period (Codoñer 2013: 135-187); Mika Levy-Rubin shows the reorganization of the patriarchate of Jerusalem during the early Muslim period (Levy-Rubin 2003: 197-226) and tensions between ideology and practice using the example of 'Umar II's giyār edict (Levy-Rubin 2016: 157-172). In turn, Ken Parry presents a topic almost shrouded in mystery of the early presence of Melkite communities in Central Asia (Parry 2012: 91-108), Alexander Treiger examines the beginnings of the Greco-Syro-Arabic Melkite translation movement in Antioch (Treiger 2020: 1-27), and Kate Leeming explores the development of the Arab Melkite religious writings, especially prayer texts, in the context of the interaction between the Mount Sinai and Mār Sābā monasteries (Leeming 2003: 239-246). Robert Turnbull distinguishes many families of texts, according to the similarities between their types and content among the surviving Arab gospel lectionaries in the Mount Sinai monastery (Turnbull 2019: 131-166). Daniel Galadza traces the process of Byzantinization in postByzantine Jerusalem (Galadza 2013: 75-94; 2018). Another interesting perspective is offered by the monograph of Vincent Déroche who, analysing some crises in Christianity, such as Christological disputes, iconoclasm, and the Photoian schism, shows the formation of the Melkite position and the identity of Orthodoxy in general long before 1054. These crises paradoxically protected the Melkites from marginalization and peripheralization (Deroche 2010). Juan Pedro Monferrer-Sala examines the formation of an ethnolinguistic identity of the Melkite communities in the Middle East (Monferrer-Sala 2012: 445-471). In turn, Christian Sahner explains the phenomenon of so-called "neo-martyrs" in the lands of Islam, including Christians from many oriental communities, among them a relatively large group of Melkite martyrs (Sahner 2018; 2020: 389-412). Daniel Sahas demonstrates the oriental character of the Byzantine-Islamic relations which were linked with the Melkites (Sahas 2013: 384-404) and provides many interesting explanations for the phenomena associated with the Melkites, such as the role of the patriarch of Jerusalem, Sophronius (Sahas 1999: 79-97; 2006: 33-44; 2009: 120-127), and "the art and non-art" of Byzantine polemics (Sahas 1990: 55-73). Luke Yarbrough critically answers the question of whether 'Umar b. 'Abd al-'Azīz issued an edict concerning nonMuslim (including Melkite) officials (Yarbrough 2016: 173-206) and 
the publication of Robert Coates-Stephens sheds a lot of light on the problem of the presence of monks from the Palestinian Saba Monastery in Rome, where a church, also dedicated to the saint Saba, was built (Coates-Stephens 2007: 223-256).

Valuable information about Melkite writers during the period under discussion was published by Georg Graf (1875-1955) in his classic work on Christian Arabic literature (Graf 1947: 3-72). Additionally, there are some studies in the form of essential overviews of the Melkite Church and its history in the context of oriental Christianity and Islam (i.e. Doucellier 1996; 1971; Musset 1948: 201-204, 251-256, 379-386; Hajjar 1962: 85-92, 114-122; Vailhé 1908: 1399-1412; Pargoire 1908: 786-801; Janin 1955: 146-171; Faivre 1914: 335-369; Amann 1924: 997-1010).

As we are collecting the pieces of evidence relevant to the material facts, we should summarize the basic sources for the history of the Melkite Church. Although we have three main chronicles by Melkite writers, the primary sources for some aspects of the history of this community are smaller or larger references scattered in dozens of Arabic Muslim, Syriac, Greek, and Latin works. In this discussion, these sources are very often used once, twice, or several times. Therefore, the relatively long list of sources in the bibliography should not be surprising (the situation is similar in the case of auxiliary works). In these circumstances, it is difficult to go into all the sources. Certainly, a critical review is required for the Melkite chronicles. On the other hand, the assessment of the other sources must necessarily be limited to selected works (the criterion of this choice will always remain somewhat controversial).

Melkite sources

Three Melkite historians allow us to partially reconstruct the history of the Melkite Church up to 969. Among them are Agapius, the Melkite bishop of Mambī̄̆ (Maḥbūb b. Qunsțanțīn al-Mambiğ̄i, died in 945). He left behind a universal history-Kitāb al- 'Unwān (Agapius 1910: 562-691; 1911: 459-591; 1912: 396-547; 1915: 5-144). Although this work does not add any new facts to universal history, it is nevertheless one of the most important sources of information about the organization of the early-mediaeval Melkite Church, which we do not find elsewhere. The surviving manuscripts usually follow a two-part chronological division. The most famous manuscripts of this chronicle are Bodl.arab.christ.Nicoll 51, $1^{\circ}$ (Hunt 478); Sin.arab. $5801^{\circ}$-989); 456, fol. 103-164v-13th century; Nasrallah 80 oriental Christianity-17th century; Saint-Sépulcre arab. 93-18th century; and Orientale 3-16th or 17th century (Nasrallah, Haddad 1979: 52).

Another, much more useful source for researching the early history of the Melkite Church is the chronicles of Sa 'îd b. Bitrīiq, or Eutychius of Alexandria, the Melkite patriarch of Alexandria (933-940). There are two forms of writing the Arabic name of 
Patriarch Eutychius. In fact, the two forms Sa ${ }^{\prime} \mathrm{i} d \mathrm{~b}$. Bițrīq and Sa 'īd b. Bațrīq are used interchangeably (Graf 1947, vol. 2: 32; Nasrallah, Haddad 1979: 23: Bițrīq, 25: Batrīq). Eutychius' work, entitled Kitāb al-tārīh al-mağmū' 'ala l-tāhqūq wa l-tașdīq and called Naẓm algawhar by later copyists, was dedicated to the brother of $\mathrm{Sa}{ }^{\prime} \overline{\mathrm{i}} \mathrm{b}$. Bitrīiq, a doctor named 'Īsa (Eutychius 1909). Sa'īd b. Bițrīq was sometimes classified in Arabic literature as șahab al-tārīh, that is, considered to be an outstanding expert in history. Eutychius' annals cite numerous facts from the history of the Church and world history. In accordance with the historiographic principle prevailing at the time, the author narrates events from the creation of the world, and discusses the birth of the Church and the heresies that emerged. This work has limited value, because Eutychius of Alexandria often drew information from questionable sources and legends. But alongside the unreliable accounts, we find facts in his chronicles that have been confirmed by other mediaeval historians. The chronicles of Sa ${ }^{1} \bar{d} \mathrm{~b}$. Bitrīq are retained in two recessions: the Alexandrian, which is considered to be the work of Bitrīq, and the Antiochian version, which is a more expanded version, including additions to unknown Melkite chroniclers and apologists between the 11th and 14th centuries. It is assumed that essentially the concept and core of the chronicles are certainly derived from Sa $\overline{1} \mathbf{1} \mathrm{b}$. Bițīq, who began his work as a chronicler before becoming Eutychius, patriarch of Alexandria. The chronicles is a "child of his time," that is, a universal chronicle, written in Arabic in the spirit of the Christian predecessors long before the Eutychius of Alexandria era. Parts of his chronicles relating to the time of Islam depend on the Muslim sources. They reveal a confessionalism, especially in the accounts of the succession of bishops and patriarchs, and especially when Melkite Orthodoxy is discussed (Breydy 1983; Michaelidis 1934: 7-27, 209-38, 344-65).

Undoubtedly, the most critical and solid history of the Melkite Church was written by Yahyā b. Sa īid of Antioch (Yahyā al-Anțakī) in the 11th century (about 980-1066). He was a harsh critic of the chronicles of $\mathrm{Sa}^{\text {'ì }} \mathrm{d} \mathrm{b}$. Bițrīq, and he also undertook to supplement and continue them (Yahya ibn Sa'id 1924: 705-833). The value of Yahya al-Anțakìs chronicle is immense. This is the only extremely reliable source for researching the turbulent history of the Melkite Church in the years 937-1033. Thanks to it, we can reconstruct the lists of patriarchs, learn about the course of the persecution of Christians during the reign of Caliph al-Hākim (996-1021) and learn about the activities and organizational problems of the Melkite Church. Paradoxically, we are unable to establish the dates of this great historian's birth and death. It is assumed that he was born between the years 975 and 980 . The date of his death is even more obscure and varies depending on the researchers: the period between 
1034 and 1066 is assumed. The latter date is the most widely accepted today (Lawrence 1991: 2213; Forsyth 1977; Graf 1947: 49-50; Nasrallah, Haddad 1983: 167-175).

Newly discovered manuscripts, such as the texts published by Mathilde Boudier related to the conflict between Metropolitan Bishop David of Damascus and Simeon of Antioch are a very important supplement to deepening the knowledge of Melkite communities in the early Middle Ages (David de Damas 2018: 60-70; Boudier 2018: 45-80).

When it comes to source texts, apart from the aforementioned chronicles, of invaluable help to historians is the anthology of sources of Arabic Orthodox literature by Samuel Noble and Alexander Treigeris (Anonymous 2014), written with the cooperation of Mark N. Swanson, John C. Lamoreaux, Krisztina Szilágyi, Sidney Harrison Griffith, Nikolaj Serikof, and Ioana Feodorov. The collections contain many previously unpublished works in an original thematic and chronological order. Of course, the publication only refers to the Melkite authors active in the period from 634 to 969 (Anonymous 2014: 40-59; Theodore Abu Qurra 2014: 60-89; Hagiography 2014: 112-135; Agapius 1910: 562-691; 1911: 459-591; 1912: 396-547; 1915 : 5-144).

General remarks on theological sources

Byzantine sources
Historians have many other documents of Melkite authors at their disposal. Some authors believe they are of less value than the chronicles, since they are mainly theological texts. Others believe that excessive pessimism in this area should be avoided. Nevertheless, these works are a valuable supplement to the chronicles and testify to the vitality and problems of the Melkite Church in the Islamic world. It is, therefore, worth mentioning at least the writings of St John of Damascus (died 749), author of many polemical texts against heterodox Christianity and Islam (Joannes Damascenus 1864a: 1421-1432; 1864b: 1135-1502; 1864c: 529-676; 1864d: 677-780; 1864e: 789-1228; Jean Damascène 1992; Johannes von Damaskos 1969-2013) and the works of Anastasius Sinaita (died after 700) which explore Christian (Melkite) dogma, ritual, and lifestyle (Anastasius 1865: 1-1288, 1389-1397; 2006). The author was one of the brave Melkite writers who undertook a critical reflection on key church issues. As a result, his works were later commented, corrected, or even censored (Sakkos 1964; Noret 2003: 7745-7781; Uthemann 2015: 774-810). In addition, the successively discovered and published manuscripts allow us to better identify many personalities of the Melkite Church or expand our knowledge about them (Ibrāhīm ibn Yūḥannā al-Anțākī 1952: 20-29; Boudier 2018: 45-80).

Byzantine sources are also useful for presenting the history of the Melkite Church, due to the connections between the Melkites and Constantinople (orientation in numerous Byzantine sources is 
facilitated by Karagiannopoulos and Weiss (1982); for more on the sources of the Arab-Byzantine conflict, see Cameron and Conrad 1992). The connection of the Melkites with the Byzantine Empire is evidenced by numerous church documents that were published in collections (see synodal and conciliar documents). These connections are also visible in Byzantine chronicles. One of the most important Greek works of this type is the Chronography of St Theophanes the Confessor (c. 758-817), a Byzantine theologian and chronicler (Theophanes 1883, 1885). This chronicle consists of two parts, the first of which shows a chronological history (annals) and the second contains chronological tables, though they are not precise. The work of Theophanes is a continuation of the chronicle of George Synkellos (died after 810). There are some indications that the author also used a collection of excerpts from other authors (Theodorus Lector [6th century], Socrates Scholasticus [c. 380-after 439], Salminius Hermias Sozomenus [c. 400-c. 450], and Theodoret of Cyrus [c. 393-c. 458/466]). According to some researchers (Mango 1978: 9-18), Theophanes contributed little to the creation of the chronicle that bears his name. However, Chronographia, created in the period 810-814, is an important source about the reign of Emperor Heraclius (610-641) and his successors. It also contains a lot of information about the situation of Christians during the Umayyad reign and in the early Abbāsid period (until 813). The chronography has the form of annals covering the history from 284 to the assumption of power by Emperor Leo V (813-820). Theophanes was a staunch opponent of iconoclasm, so he was not very objective when it came to certain subjects. On the other hand, his annals are based on authentic sources; therefore, they are of prime importance to the historians of Byzantium in the 7th and 8th centuries. Still, despite some its imperfections, this work is vital in the research on the Arab world (Conard 1990: 1-45).

Historia syntomos, breviarium of Patriarch Nikephoros I of Constantinople (c. 758-828) covers the period between AD 602 and AD 769. The author used the chronicle by Trajan the Patrician (VII/VIII) and some of the same sources, missing today, which explored the above-mentioned Theophanes. Although Nikephoros' work is much less extensive and has fewer details, it provides a good comparative source and, in some aspects, it is more objective (Nicephorus 1863: 683-994). Unfortunately, Nikephoros' chronographic calculations are full of errors, so they are difficult to use.

Some interesting information about the political and religious contexts for the existence of the Melkite Church can be found in the writings of the Byzantine emperor Leo VI (886-912), known as the

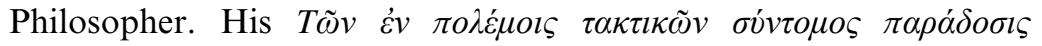
("Short instruction of the tactics of war," or Tactica) shows the 


\section{4}

Introduction

broadly understood organization and war experiences of the empire in the confrontation with, for example, Arab enemies (Leo VI Sapiens 1863b: 669-1116). In turn, his Epistola ad Omarum Saracenum de fidei Christianae veritate \& Saracenorum erroribus shows a peculiar apologetic paradox. The text presents the Byzantine critical approach to the Islamic world in which the Melkites lived (Leo VI Sapiens 1863a: 315-324).

Among the numerous works of Emperor Constantine VII Porphyrogenitus (913-959), the treatise De administrando imperio was fairly useful for this analysis (Constantinus Porphyrogenitus 1864: 158-422). It contains a lot of information on Byzantine diplomacy and the organization of foreign peoples. De administrando imperio, although not free from unfounded claims, is a priceless source for the history of the 10th century Byzantium, along with information about neighbouring peoples.

This research also marginally refers to other Byzantine works: the treatise Adversus Constantinum Caballinum (against Constantine V Kopronymos) - wrongly assigned to John of Damascus (Adversus Constantinum Caballinum 1864: 309-344) - Vita Sancti Demetriani (Vita Demetriani 1907: 217-237), etc. In turn, the following Greek authors are helpful in portraying the historical background of the Melkite Church before the 7th century: Procopius of Caesarea (c. 500-c. after 565), a scholar from Palaestina Prima (Procopius 2008), John Malalas (491-578), a Greek chronicler from Antioch (Ioannis 2000) and others (von Skythopolis 1939; Sozomen 1890; Epiphanius 1916: 828-868).

Synodal, council and papal documents and collections of other ecclesial sources

Coptic sources
An important group of sources for this study are also Greek and Latin documents of councils and synods of Church in the East and West. Above all, the Sacrorum conciliorum nova et amplissima collectio, Mansi's edition, is a priceless, classic collection of church documents, because it contains not only conciliar decrees but also a large amount of material related to various synods and councils. Moreover, various types of information of direct and indirect importance for the history of the Melkite Church can also be found in Liber Pontificalis (Liber Pontificalis 1886-1957).

Critical editions of sources for individual councils or collections of papal writings are also tremendously helpful. The stories of the councils written from sources are also very useful in historical research (Hefele 1907-1952). Moreover, the Pilgrims provide very interesting information in their travel descriptions.

Coptic sources are also of great importance, especially the major historical work of the Coptic Orthodox Church of Alexandria, The History of the Patriarchs of Alexandria, written in Arabic (Muqqaffa 1904, 1907, 1910a-1910c). According to many researchers, this history was wrongly attributed to the Coptic bishop of Hermopolis 
(Ašmunain), Severus (Sāwīrus b. al-Muqqaffa' [955-987]). For many decades, there has been a discussion about the compilatory character of this work and its authorship. The History of the Patriarchs of Alexandria is a fundamental reference for the history of the Coptic Church and the official history of the Alexandrian patriarchate. The work outlines 75 biographies of patriarchs up to 1243 written by various authors (Heijer 1989; 1990: 107-113; Martin 1985: 15-36).

In turn, John of Nikiû (7th century), a Coptic bishop of Nikiû (or Pashati, now Zawyat Razin in the Nile Delta) who worked at the end of the 7th century, left us an interesting Chronicle of the World (Jean de Nikioû 1883), which is an important source for researching the rule of Emperor Heraclius (610-641), the Byzantine presence in Egypt and its conquest by Caliph 'Umar (634-644) in the years 639 to 641 . This chronicle was probably written in Coptic, though some authors argue that it was originally written mostly in Greek. It has survived to today in the Arabic and Ethiopian versions (HowardJohnston 2010: 181-189; Suermann 2002a: 167-186).

The fundamental importance of Syriac sources cannot be overestimated. First, the history of Dionysius of Tel-Mahrē (died 845), patriarch of the Syriac Orthodox Church ("Jacobite Church") from 818 until his death in 845 (Dionysius of Tel-Mahree 1993), was used. Undoubtedly the most valuable source is the monumental chronicle of Michael the Syrian (1126-1199), patriarch of the Syriac Orthodox Church from 1166 to 1199 (Michael le Syrien 1899, 1901, 1905, 1910). This work spans the history of the world from creation to 1196 and contains many citations, copies, and summaries of the works of his predecessors. Michael was a great historian and narrator. Each page of his chronicle was divided into three parts. The first, left column informed the reader about natural events, such as solar eclipses, earthquakes, and cataclysms. The middle column included the events of universal history, while the third dealt with church life (manuscripts with only two columns have also survived). As the patriarch, Michael was invited by Byzantine emperor, Manuel I Comnenos (1118-1180) to negotiate a reunion of the churches. But Michael, who did not trust the Greeks, refused. This chronicle contains some information on the relationship between the "Jacobites" (Syriac "Monophysites") and the Melkites (Weltecke 2003; Tubach 1993: 1467-1471).

Bishop Bar Hebraeus, or Gregory Abū al-Farağ (1226-1286) also left a very valuable historical work. The author came from Little Armenia (Armenia Minor). He took refuge with his family in Antioch, when escaping from the Mongols. At the age of 17, he became a hermit; at the age of 20 he was consecrated bishop, and when he reached the age of 26, he became an archbishop. From 1264 he was the "Jacobite" patriarch. Bar Hebraeus visited the libraries of 
Latin sources

Muslim sources
Syria and Armenia, thus collecting an invaluable range of sources. He wrote many works, among which the following are most important for this study: the great universal history called Chronography (Chronicon Syriacum), from the creation of the world to 1286 (Bar-Hebraeus 1890), and the Church history Chronicon Ecclesiasticum, describing the history of the "Jacobite" Church from Aaron to his contemporaries (Bar-Hebraeus 1874).

In principle, the great Syriac historiography ("Jacobite") ended in the 13th century with the works of Bar Hebraeus. Until the 20th century, it no longer had representatives of the rank of Michael the Syrian or Bar Hebraeus. Among the Syrian "Nestorian" writings, the chronicle of Mārī b. Sulāymān (13th century) deserves our attention (Mārī b. Sulāymān 1896-1899).

The so-called Latin world had been interacting with the Melkites since antiquity. One of the most spectacular interactions with the Melkites in the early mediaeval period was the contact between Charlemagne (742-814) and the West with Jerusalem. This is reported by various sources (e.g. Chuonradus Constantiensis 1841: 430-436), among which the most informative is Einhard's Vita Karoli Magni (Einhard 1911), considered one of the most precious historical accounts of the early Middle Ages (Innes 1996-1997: 265-282; Hodgkin 1897: 222).

The Muslim sources used in this book are not only of unequal historical value, but also relate to the main topic to varying degrees. In fact, these are usually short, laconic references to the condition of the Melkite community (Nasrallah 1978: 108-112). Among them, the works of chroniclers undoubtedly have the greatest merit. On the other hand, the writings of theologians allow us to restore the status of Christians in the lands of Islam. Only the chronicles are discussed below, and other sources - those less helpful to understanding the history of the Melkites - are only mentioned.

A historian of Persian origin, 'Aḥmad b. Yahyaa al-Balādurī (died 892), was primarily concerned with describing the expansion of Islam. He spent most of his life at court in Baghdad and Syria. His main work, Kitāb futūh al-Buldān ("Book of the Conquests of Lands"), describes the first years of the Arab expansion (from Arabia west to Egypt, North Africa, and Spain, and east to Mesopotamia, Persia, and Sind) and the level of civilization in the countries occupied by Arabs (Balādhurī 1866, 1916).

Undoubtedly, one of the most valuable sources is the chronicle of Ibn al-Ațìr (1160-1233), Al-Kämil fi 'al-Tārīh ("The Complete History") (Ațīr 2001). Although al-Kämil is often considered a valuable work, especially for the Crusades period, which was contemporary for the author, in fact the work is one of the monumental books on universal history. The Umayyad and Abbasid section also 
provides some information about the Melkites. The historian is highly esteemed for his objectivity and wealth of information. alKämil, however, often largely draws on Al-Ṭabarī.

Since the name of the eminent historian and theologian from northern Persia, Muḥammad b. Ğarīr al-Ṭabarī (839-923), was recalled, it is worth presenting his most famous historical work, Tārīh al-rusul wa- " l-mulük ("The History of the Prophets and Kings"), in which he recounts the events from the creation of the world to the present day of the author (Tabarī, The history vol. 1-39, 1985-2007). The work contains relatively many references to the Melkites. In his chronicle, Al-Ṭabarī discussed each year in turn, recording the most important events.

Several Muslim works are useful in pinpointing the locations and fleshing out descriptions of many Melkite sites and buildings. The works of the encyclopaedist Abū'l-Hasan 'Alī b. al-Ḥusain alMas' ūdī (c. writing 895-957) are valuable sources. Especially the treatise Murūğ al-d̆ahab wa-ma 'ädin al-ğauhar ("Meadows of Gold and Mines of Gems") was used for this research. The treatise contains a lot of information about the geography and history of various peoples (Mas'ūdī Pellat 1979; Mas 'ūdī Meynard and Courteille, vol. $1-9,1861-1877)$. The second valuable work by this author is Kitāa alTanbīh a- 'l-išrāf ("Book of Admonition and Revision"), in which alMas' ūdī corrected and supplemented his previous study (Maçoudi 1896). In fact, it is an abridged Murüğ al-dahab; however, it contains new material on the Byzantines. This author's interest was indeed "humanistic," as he devoted much attention to non-Muslim culture (Shboul 1978; Khalidi 1975).

In turn, the traditions collected by 'Alī b. al-Hasan b. Hibat Allāh b. 'Abd Allāh b. al-Ḥusain Abū 'l-Qāsim al-Šāfi 'ī al-Dimašqī, known better today as Ibn 'Asākir (1105-1175) are one of the most important sources on the takeover of the basilica of St. John the Baptist by Caliph Walīd I. His massive Ta'rīh madinnat Dimašq, however, is a historical work helpful for our understanding of the first five centuries of Islamic history and the transformation of Melkite Damascus into a Muslim city (Ibn Asākir 1959).

All kinds of information that directly or indirectly refers to the Melkites or sometimes generally to the condition of Christians in the Middle East, seemingly quite minor but also important in some way, are scattered in numerous works by Muslim authors, such as Abū'l Qāsim 'Abd ar-Raḥman bin 'Abdullah bin 'Abd al-Ḥakam (803-871), historian (Ibn 'Abd al-Ḥakam 1922); Mālik b. Anas (711-795), a theologian and lawyer (Mālik 1951: vol. 1-2); Muḥammad b. Idrīs al-Šāfi '̄i (767-820), a theologian (Šāfi '̂̀ 1961); Abū 'Īsā Muḥammad b. Hārūn al-Warrāq (died 861), an Arab skeptic scholar and critic of religion (Warrāq 1992); Abū Bakr 
Muḥammad b. Yaḥyā b. al-'Abbās al-Ṣūlī (c. 870-c. 948), a historian (Șūlī 1946, 1950); 'Amr b. Baḥr al-Ğāhị (c. 776-869), a scholar (Ğāḥiz 1926); Abū Muhammad 'Abdallah b. Muhammad b. 'Umayr Maḥfūz al-Madini al-Balawī (10th century), a biographer of Ahmad b. Țūlūn (868-884), the founder of the Tulunid dynasty that ruled Egypt and Syria between 868 and 905 (Balawī 1939); Muhammad b. Abī-Nașr al-Ḥumaydī (11th century), an author of a biographical dictionary of rulers, scholars, and poets ( $\check{G} a \underline{d} w a t$ almuqtabis fì ta'rīh 'ulamä' al-Andalus ("Firebrand for the Seeker of Illumination about the Scholars of al Andalus") (Salimi 2014); and Abū Manșūr al-Ta ālibī (961-1038), an anthologist and collector of epigrams (al-Ta àlibī 1885).

The consequence of using various sources is that one must synchronize different chronologies. All dates are based on the current modern Western calendar. It does not seem necessary to provide dates in different time systems, which could not help, but would rather complicate and obscure the chronology of events. In order to visualize the complicated world of Eastern dating in various sources, it is worth giving two examples.

In the Eastern Empire, the chronology began with the creation of the world, which was measured in various ways. The most widespread calendars were the Alexandrian Era from 5492 BC and the Byzantine Era, which began in 5508 BC (Grumel 1958, 85-97, 111-128). Byzantine historians themselves had problems with the proper application of this dating. For example, Theophanes, while describing the events in his Chronographia, gives both the year according to the Alexandrian era and the relevant indication. However, due to an incorrect distribution of material for the period from 6102 (i.e. 609-610) to 6256 (i.e. 772-773), the dating is inaccurate.

On the other hand, the Muslim chronology based on the lunar year begins with the departure of Muhammad from Mecca for Medina (Hijra), which, according to the Christian calendar falls on 15 July 622. In each 30-year cycle calculated from the Hijra, ordinary years are 354 days and 11 years are 355 days, so the Islamic year is not the same as the Christian year. These "missing" 11 days in a lunar year in relation to the solar year result in an additional lunar year every 33 lunar years. In other words, after 33 solar years we have 34 lunar years (Kościelniak 2013: 21-60). 


\section{The development of the Melkite Church until the Arab conquests}

The information relating to the origins and condition of the Melkite communities before the rise of Islam will allow us to understand the first Melkite-Muslim interaction (the "starting point" of the research) in 634. They constitute a very important historical context placed in the perspective of the doctrinal disputes of the ancient church, which gave rise to the Melkite patriarchates. It is most fascinating how the oldest heritage of the metropolises of Antioch, Alexandria, and Jerusalem, which turned into patriarchates, forms part of the common heritage of all communities separated later. Many transformations, from the diverse episcopate, through the metropolitan system, to the exarchate, in the context of doctrinal disputes resulted in the formation of separate patriarchal institutions. The official orthodox position and validity with the support of the emperor was finally reserved in Byzantium exclusively for the Melkite patriarchs.

From the Melkites' standpoint, the ancient Church overcame Gnosticism and Arianism without long-standing divisions (4th century). Soon, however, there were lasting rifts in Christianity related to the discussion of the nature of Christ. They also led not only to the crystallization of the name "Melkites" but also to the separation between the conflicted churches. The discussions were mainly related to the resolutions of the Councils of Ephesus (431) and Chalcedon (451).

\subsection{The genesis of the Melkite Church}

Looking for the genesis of the Melkite Church, one should take into account not only the etymology and meaning of the name Melkite Church, but above all, the outline of its history up to the first half of the 7 th century, that is, the Muslim conquests. Without this information, it is impossible to understand the remarkable situation of this Church in the early Middle Ages, which could be dated from 634 to 969 for the Melkite communities. 


\subsubsection{The etymology, meaning, and history of the name "Melkites"}

Etymology and meanings of the name "Melkites"
More than 1,500 years have passed since the first use of term "Melkites," but this name became extremely popular and permanently entered the literature and practice of life. The followers of the Council of Chalcedon in the ancient patriarchates of Antioch,

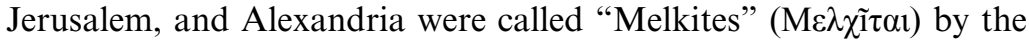
Copts, and their "monophysical" opponents were called "Jacobites."

"Monophysites" used the term "Melkites" to denote the Christians who sided with the Byzantine emperor. The name was derived from the ملكي (malkāyâ) meaning "imperial" and the Arabic word meaning "royal," and by extension, "imperial" from مل malik — "king" (Macke 1993: 413; Valognes 1994: 285-286; Madey 1998: 206). This term has an equivalent Greek word $\beta \alpha \sigma \lambda$ cús. It was first used by the "monophysical" Copts in AD 460 to denote "Catholics" who were faithful to Timothy III Salophakiolos (460-475, 477-482), the Orthodox patriarch and protégé of the Byzantine emperor Leo I (457-474) in Alexandria (Sacra Congregazione 1932: 134). On the other hand, it is worth remembering that the religious divisions did not correspond exactly to the national divisions, because "Monophysitism" also had its followers in Greek cities. Nevertheless, in Syria and northern Mesopotamia, "Monophysitism" was embraced better than the dogmas of Chalcedon, which is why Syriac Christians called the supporters of orthodoxy "Melkites" as "people of the emperor" (Wipszycka 1994: 248). In Syria, this name was adopted permanently after the Muslim conquests. In the sources related to the "Nestorian" patriarch Timothy I of Seleucia-Ctesiphon (780-823), the term "Melkites" appears relatively frequently (Dib 1930: 157; Parlato 1969: 27; Przekop 1984: 179).

Since at that time the Byzantine emperor made claims for the care and support of "Christian righteousness," supporters of the Chalcedonian Orthodoxy were simply called "the supporters of the king." However, it should not, as already mentioned, be uncritically referred to as the "Greek Orthodox Church." The Melkites were simply not always in favour of the religious policies of the Byzantine emperors. In fact, the so-called "Melkite Church" was also formed from anti-Monothelite Syrian, Palestinian and Egyptian Chalcedonian groups. The policy of the Byzantine emperors, especially of Justinian I (527-565), was aimed at closely linking religion and the state (Procopius 1962-1964; Prokopios 2010; Ioannis 2000; Theophanes 1885). Obviously, not all heterodox movements met with the acceptance of the authorities, because they were perceived as a threat to Greek domination in the East. Justinian I played a decisive role in the ongoing doctrinal dispute between the "right-faith" option 
and the "Monophysites" (Cassetti 1958; Bréhier 1948: 437-482; Capizzi 1994). The imperial decree of 543 (or 544), by which he wished to persuade the "Monophysites" to accept the decisions of the Council of Chalcedon, became a pledge of a long and insurmountable dispute. The fifth ecumenical council called by Justinian in 553 in Constantinople also failed to bring about reconciliation, and the administrative persecution of the "Jacobites" and Copts sealed the split. All of Chalcedon and Byzantium later came to be called "Melkites." In the 9th century, in the Middle East there were two groups referred to as "Melkites." The first group was the "Melkite Maximites," from the name of St Maxim the Confessor (died 662), who ultimately adopted the Byzantine Imperial liturgical tradition. The second community was the "Melkite Maronites," who continued their Syriac liturgical tradition (Dib 1930: 146; Przekop 1984: 179; Duchesne 1925: 66-67).

During the Umayyad caliphate, the Christians who accepted the teachings of the Sixth Ecumenical Council of the Imperial Byzantine Church in 681 were finally identified as "Melkites" (Monferrer-Sala 2012: 445; 449-450). Despite the tightening ties with Constantinople, the Melkite patriarchates almost always tried to emphasize their individuality, even if often only symbolically. It is significant that the term al-rūm (pl. al-arwām) was used to denote the Romans and Byzantines belonging to the Greek Orthodox Church and that mal (a) kī/milki referred to Arabic-speaking Christian Chalcedonians living in the territories of Dār al-Islām (Monferrer-Sala 2012: 450; Nasrallah 1974: 496).

Therefore, the name "Melkites" was later widely adopted by Muslim Arabs. The Melkites, who had a privileged position in the empire during the Greek rule, did not always enjoy a friendly welcome from the new authorities. For Muslims, the term "Melkites" usually meant a simplified reality: Christians faithful to Byzantium, that is, the communal subject, from the caliphate's point of view, to the usually hostile great power from outside. The Muslims suspected Christians previously associated with the Greeks of maintaining contact and conspiring with Byzantium. In this context, the name "Melkites" became extremely handy and reflected the essence of Muslim thinking about Christians that belonged to the circle of Greek (Western) culture.

Nonetheless, the Muslim perception of the Melkites as partners in relations with Constantinople was not unfounded. The continuation of the ties was evidenced by the fact that they agreed to replace the Antiochian rite and liturgy with the Byzantine tradition at the turn of the 11th and 12th centuries. This was the result of a long process, however (Galadza 2013: 75-94; Galadza 2018). In other words, this

The term "Melkites" after the Muslim conquests 
explains why the Melkite patriarchates, despite their willingness to assert their independence, entered the world of the Byzantine rite (Duchesne 1925: 66-67; Sacra Congregazione 1932: 134-151).

\subsubsection{The "Melkites" and the Roman Catholic Church}

There is therefore no doubt that between 634 and 969 the Melkite patriarchates were part of the "Catholic" Church in the broad sense of Chalcedonian orthodoxy. Some authors interpret the history of the Melkite community as always having more or less loose relations with Rome even after the Great East-West Schism (1054). For example, Yūsuf Nașrallāh (1911-1993) stressed that some Melkites maintained contact with Rome until the 16th century (Nasrallah 1976a: 43-44; Nasrallah, Haddad 1981: 76). However, there is a debate if "portraying Antioch as having always been pro-Roman is more the Greek Catholic foundational myth" or a well-documented reality (Samn 2010). Back to the etymology, taking into account mediaeval sources, one may observe that the term "Melkite" was often used in premodern Arabic by "Catholic"/Orthodox (before 1054) and Orthodox authors (before 1724). This term was supposed to distinguish the adherents of orthodoxy from Christian heterodox groups, who also defined themselves with the adjective "Orthodox" (e.g. Syriac "Monophysites" from the Syriac Orthodox Church were informally called the "Jacobites" by Greeks). Whatever the interpretation of this controversial period of the schism for Antioch, there is the open question of whether the term "Melkites" was also applied before 1054 by non-Chalcedonian authors in the Middle East to Christians subordinate to the papacy and patriarchy of Constantinople. After the Melkite community split in 1724, when some Melkites signed a union with Rome, the term "Melkites" became unpopular among those Melkites who did not intend to build a lasting relationship with the papacy. In reality, the Arab-speaking Orthodox Chalcedonian Christians were sometimes imprecisely called Greek Orthodox. On the other hand, the name "Melkite" was well assimilated by the Melkite Catholics (also quite often wrongly called Greek Catholics).

Over time, also among Western Christians, the name "Melkites" meant the Arab followers of Christian Orthodoxy in the frame of the patriarchates of Antioch, Alexandria and Jerusalem (Treiger 2019: 7-37). It is a separate issue how the Melkite patriarchates of Antioch, Alexandria and Jerusalem were drawn into the drama of the East-West Schism (Haddad 1965) and the conversion of Eastern Orthodox Christians to the Union in the 17th and 18th centuries (Haddad 1990).

The modern meaning of the term "Melkites"
The name "Melkites" survived subsequent epochs - the times of the Crusaders, Turkish domination and colonialism - although the original linking of this group of Christians with Byzantium had no 
political basis, especially after the fall of Constantinople in 1453. Since 1724 there have been two Melkite Churches: Catholic, linked with Rome, and Orthodox, as independent patriarchates. It has already been mentioned that after the dissolution of the Melkite community (into the Melkite Catholic and the Melkite Orthodox), the term "Melkites" became unpopular among Arabic-speaking Orthodox who remained faithful to the Greek Orthodox patriarchate of Constantinople.

Thus, the term "Melkites" has now become imprecise owing to a kind of duality of the historical identity of the Melkite Church. In this situation, many Western authors limit their use of this name only to the Melkite community associated with Rome (Madey 1998: 206).

\subsubsection{The place of the Melkite rite among oriental liturgies}

Since antiquity, the Christian East was characterized by a variety of The origin of the rites liturgical practices and forms of cults, ceremonies and worships, which are called rites. The richness of the rites grew systematically with the development of the Church, its models and traditions. The foundation of the diversity of the rite of the Mass was liturgies shaped by the theological centres of Alexandria, Antioch, and Jerusalem. Centuries later, Constantinople merged them with its buoyant and lavish Byzantine liturgy.

Ancient Alexandria boasted a form of liturgy known as the Liturgy of Saint Mark (St Mark is credited with apostolic activity in Egypt). This rite, originally performed in Greek, became common in towns and villages. However, soon the Coptic language began to dominate in Christian worship in small settlements, especially in Upper Egypt.

When "Monophysitism," which was strongly associated with the Coptic minority in Egypt, was condemned, there was a split in the Alexandrian rite: a small, Hellenized group of Christians faithful to the decrees of the Council of Chalcedon, or Melkites, remained with the Alexandrian rite in Greek. Over time, this rite assimilated many elements of the Byzantine liturgy. The Copts, on the other hand, used the Alexandrian rite in the Coptic style, which was further modified in the following centuries (Burmester 1967).

From Egypt, Christianity spread to Nubia and further to Ethiopia. The evangelization of these countries was the work of "monophysical" missionaries from Egypt. So it is not surprising that it was they who brought Alexandrian liturgy to Abyssinia. Obviously, this

Origin of the Melkite rite in Alexandria 


\section{4}

The development of the Melkite Church

Origin of the Melkite rite of Antioch

The Antiochian rite as the basis for other rites

Great influence of the Byzantine rite

Eastern liturgical rites liturgy was performed in Ge'ez and over time it was also significantly modified (Hammerschmidt 1961).

Two centres of ancient Christianity participated in shaping the Antiochian liturgy, also known as the Syriac rite: Antioch and Jerusalem. In Jerusalem, the liturgy of St James was practiced and other forms of the Mass were possibly also celebrated in Greek and sometimes also in Aramaic. Greek and Syriac were also used in the Antiochian liturgy. After the Council of Chalcedon, the Syriac "Monophysites" known as "Jacobites" adopted only the Syriac language in their rite. Greek remained in Melkite use in both Jerusalem and Antioch. As a result of strong ties with Constantinople, as has already been mentioned, the Melkites adopted the Byzantine liturgy. With time, after the Muslim conquests, as a result of a strong process of Arabization, they started celebrating mass in Arabic.

Originating in the Antiochian tradition, the "Jacobite" rite took on a new shape in the use of Syrian Catholics, that is, some "Jacobites" who signed the union with Rome. The Maronite Church, which comes from the Antiochian Church (never separated but in full communion with Rome since the Middle Ages), also has its rite nowadays which is a compilation of Syriac Antiochian and Roman elements (Hayek 1964). The Syriac language was also used in other Churches: the "Nestorian Church" and the Syro-Malabar Church in India originated from it (Vellian 1970) as well as the Chaldeans, or "Nestorians-Uniates," who were in union with Rome. The Armenian Apostolic Church has its original liturgy, the roots of which can be traced back to the influences of Antioch and Caesarea in Cappadocia (Baumstark 1953: 256-258). The "Nestorian" and Malancara rite, both celebrated in Syriac, also derive from the Antiochian liturgy (Pallikunnil 2017).

The liturgy that played the greatest role in the East was the Byzantine rite, which developed under the influence of the traditions of Antioch, Caesarea in Cappadocia and the liturgy of StBasil. This rite also significantly evolved throughout history from the 4th to the 10th century and was translated into various languages: Arabic, Georgian, and Slavic. It was the Melkites of Syria, Palestine and Egypt that, from the Middle Ages onwards, used the Byzantine liturgy, which was slightly modified, and most of all translated from Greek into Arabic and sometimes into Syriac. In this way, one could speak of an "Arabized" Greek liturgy (Tannous 2017: 151-180; Leeming 2003: 239-246; Couturier 1930; Brock 1972: 119-130).

Finally, it is worth comparing the place and types of Melkite rites with Christian oriental rites (Tables based on Gatti, Karalevskij, Janin 1942: XVI-XVII; Janin 1955; Hanssens 1932; Raes 1962). 
1 List of Eastern liturgical rites:

\begin{tabular}{lll}
\hline Rite family & Name of the rite & Individual rite \\
\hline Antiochian & West Syriac & a "Jacobite" \\
& & b Maronite \\
& East Syriac & c Malankara \\
& a "Nestorian" \\
& b Chaldean \\
Alexandrian & Coptic & a Coptic \\
& Ethiopian (Ge'ez) & b Coptic Catholic \\
& & a Ethiopian \\
Byzantine & see detailed Table 2.D & \\
\hline
\end{tabular}

2 The place of Melkite rites within the oriental liturgies of individual patriarchates (rites related to melkites are marked in bold)

\section{A Antiochian rite}

\begin{tabular}{|c|c|}
\hline Name of rite & Liturgical language \\
\hline $\begin{array}{l}1 \text { "Monophysical" of Syria and } \\
\text { Mesopotamia ("Jacobite" currently } \\
\text { within the Syriac Orthodox Church) }\end{array}$ & West Syriac, Arabic \\
\hline $\begin{array}{l}2 \text { "Monophysical" of India (Malankara, } \\
\text { currently within Syriac Orthodox } \\
\text { Church of India) }\end{array}$ & East Syriac, Malayalam \\
\hline $\begin{array}{l}3 \text { Melkite Syriac Antiochian } \\
\text { (Orthodox Catholic until the end } \\
\text { of the 11th century, when it was replaced } \\
\text { by the Byzantine rite) }\end{array}$ & Greek, West Syriac, Arabic \\
\hline 4 Maronite & West Syriac, Arabic \\
\hline
\end{tabular}

\section{B Alexandrian rite}

\begin{tabular}{lll}
\hline Name of rite & Version & Liturgical language \\
\hline $\begin{array}{l}\text { Melkite traditional (Orthodox } \\
\text { Catholic: until the end of the }\end{array}$ & Alexandrian & Greek, Coptic [?] \\
$\begin{array}{l}\text { 11th century, when it was } \\
\text { replaced by the Byzantine rite) }\end{array}$ & & \\
$2 \begin{array}{l}\text { "Monophysical" Copte (currently } \\
\text { within the Coptic Orthodox Church } \\
\text { of Alexandria) }\end{array}$ & Alexandrian & Coptic, Greek \\
$\begin{array}{l}\text { "Monophysical" Ethiopian } \\
\text { (currently within the Ethiopian }\end{array}$ & Ethiopian & Ge'ez \\
$\begin{array}{l}\text { Orthodox Tewahedo Church) } \\
\text { Ethiopian Catholic }\end{array}$ & Ethiopian & Ge'ez \\
\hline
\end{tabular}


C Persian-Chalean rite (Ktezyfon-development of the Antiochian rite)

\begin{tabular}{|c|c|}
\hline Name of rite & Liturgical language \\
\hline $\begin{array}{l}1 \text { "Nestorian" (currently within the Church of } \\
\text { the East) }\end{array}$ & East Syriac \\
\hline 2 Chaldean Catholic & East Syriac, Arabic \\
\hline 3 Malabar Catholic & East Syriac \\
\hline
\end{tabular}

D Byzantine rite (Constantinople—development of the Antiochian rite)

\begin{tabular}{ll}
\hline Name of rite & Liturgical language \\
\hline 1 Old Byzantine (used in Constantinople and & Greek \\
Cappadocia from the 8th to the 10th century) & \\
2 Old Georgian & Georgian \\
3 Old Kiev & Old Church Slavonic \\
4 Old Byzantine Melkite & West Syriac, Arabic \\
5 Traditional of Sicily and Calabria & Greek \\
6 Old Russian & Old Church Slavonic \\
7 Greek Catholic & Old Church Slavonic \\
8 Romanian (Transylvania, Moldova, Bukovina, & Romanian \\
Bessarabia) & \\
9 Georgian & Georgian \\
10 Greek & Greek \\
11 Italo-Albanian Unite & Greek \\
12 Albanian & Albanian \\
13 Bulgarian & Old Church Slavonic, \\
14 Melkite Catholic & Bulgarian \\
\hline
\end{tabular}

To sum up, the Melkite rites are classified as Byzantine liturgy. The Byzantine rite occurred in the areas of the former political and missionary influence of Constantinople. It was represented by five main liturgical languages: Greek (in Hellenized regions), Old Church Slavonic (in Russia, Serbia, and Bulgaria), Romanian (in Romania), and Arabic among the Melkites (Orthodox and Catholics) who lived in Syria, Egypt, and others region of the Middle East.

\subsection{The condition of the Melkite Church until the Arab conquests}

The condition of the Chalcedonian option, that is, the Antiochian, Alexandrian, and Jerusalem patriarchates, helps us to understand the problems of these communities after the Arab conquests. For three reasons, this discussion is only a sketch which avoids an exhaustive 
account of the history of these patriarchates. Firstly, it should be remembered that describing the Orthodox Church with the adjective "Melkite" (as an opposition to so-called "Monophysitism"!) is related to the period after 451. Secondly, in accordance within the research period, it is appropriate to focus on the epoch from 634 to 969. Finally, it must be admitted that the patristic period of the Eastern Churches has been thoroughly researched.

\subsubsection{The patriarchate of Antioch}

The Antiochian patriarchate rightly takes pride in its ancient and apostolic origins. This church is mentioned in the Acts of the Apostles (11, 11-27; 14, 21, 26; 15, 22-23, 30-35; 18, 22; Acts 11:26: "The disciples were first called Christians in Antioch"), and Eusebius of Caesarea in his history claims that the community of Christians in Antioch was founded by St Peter (died between 64 and 68) before it became the Roman bishopric (Eusebius 1999: III: 36). Antioch was of great importance to early Christianity, even greater than that of Jerusalem, especially in the development of theology and the number of Christians (Zetterholm 2003; Slee 2003; Drijvers 1984).

The history of the Antiochian hierarchs is extremely interesting and colourful. This episcopal see had a list of great thinkers, saints, men of action and relentless defenders of the faith, as well as heresiarchs (Downey 1961). Due to the fact that this book deals with the Melkites from the 7 th to the beginning of the 16th century, this review of the Antiochian hierarchy is limited to presenting the most prominent and well-known bishops from the period preceding our research. This presentation will show the heritage of the Antiochian patriarchate at the time of the Muslim conquest.

The Melkites of Antioch have always been proud of the tradition of martyrs, which was also remembered during the Muslim persecution. In the first three centuries after Christ, Antiochian patriarchate was marked by many persecutions. The list of patriarchs from this period indicates that most of them won the crown of martyrdom. For example, during the reign of Nero (54-68), St Evodius was martyred. At the beginning of the 2nd century, during the reign of Emperor Trajan (98-117), St Ignatius the Bishop was killed (70-107), torn apart by wild animals, most likely consecrated by St Peter (died between 64 and 68) or St Paul (5-c. 64/67). Interestingly, this saint testified to the exceptional position of the successors of St Peter and the primacy of the bishop of Rome (literally "presides the charity," see the famous and

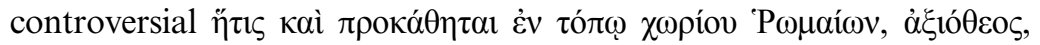

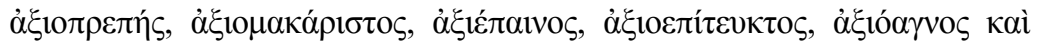

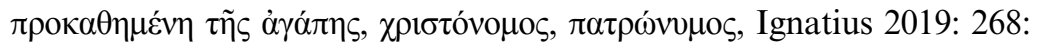
Prologue). This testimony was invoked by the Melkite supporters of the

Apostolic origin of patriarchate

Martyrs of Antioch 


\section{8}

The development of the Melkite Church

union with Rome. Saint Ignatius of Antioch enjoyed exceptional veneration among Syrian Christians of both the Syriac and Greek cultures in the following centuries. This is evidenced, for example, by the fact that "Jacobite" patriarchs very often took the name of Ignatius during their consecration (Bomes 1976; Paulsen 1979; Bosio, Covolo, Maritano 1990: 88-106; Pettersen 1990: 335-350).

This persecution went beyond the hierarchy. Since the reign of Nero, Antioch had thousands of lay martyrs. Tradition mentions, for example, 11,000 martyrs: soldiers who accepted the Christian faith during the reign of Emperor Trajan. For this act, they were sentenced to exile to Armenia, where they were murdered during the reign of another Roman emperor: Hadrian (117-138).

Initially, until AD 135, the bishops of Antioch came from Christians of Jewish origin. The last Judeo-Christian hierarch was Jude.

Antioch: the centre of theological thought
Tradition of the heterodox movements: Paul of Samosata (260-270)
For centuries, the Melkites drew on the wealth of ancient thinkers of Antioch because this metropolis became one of the most important centres of Christian learning and orthodoxy (Vailhé 1912: 109-125). It is worth mentioning the most famous authors. Saint Theophilus from the 2nd century became known as a great erudite and thinker who passionately fought against the pagan ideas and heretical teachings of the Syrian Gnostics. Saint Babylas (237-253) became famous for stubbornly refusing entrance to the church to the Emperor Philip the Arab (244-249), until the ruler repented for his crimes (this happened much earlier than St Ambrose of Milan [Pohlsander 1980: 463-473]). Saint Babylas was martyred during the reign of Emperor Decius (249-251), but the exact date is unknown due to ambiguities in Eusebius of Caesarea (Eusebius 1999: VI: 39). Melkites celebrated his liturgical feast day on 4 September (Eparchy of Newton 2020). Among the Antiochian bishop/theologians, Lucian of Antioch, a martyr (c. 240-312), who was murdered in Nicomedia a year before the Edict of Milan entered into force (313), had a significant place. This great biblical scholar devoted an in-depth study to the Gospel and the Septuagint. The theory that he was a student of Paul of Samosata, the precursor of "Nestorianism," has already been challenged, although traces of Arianism can be found among his students. Antiochian theology played a large role in the process of crystallizing of the Christian doctrine. Diodore of Tarsus (378-390), a strong supporter of the orthodoxy of Nicaea and founder of one of the most influential centres of Christian theology in the early church (Abramowski 1955-1956: 252-287), was also a teacher of St John Chrysostom (c. 350-407) and an author of the greatest homily of the Greek Church (Baur 1929-1930).

On the other hand, this patriarchate had a long tradition of heterodox movements. One of the first heresiarchs was Paul of Samosata (260-270), a bishop who owed his career to Zenobia, Queen of Palmyra (died c. 274). He was probably the first, long before 
Nestorius (c. 383-451), to lay the foundations for the doctrine of the dual nature of Christ (Millar 1971: 1-17). It was Paul of Samosata

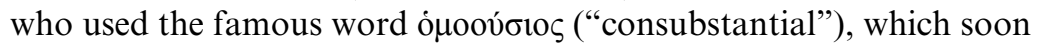
became one of the most prominent terms in Trinitarian discussions. Two Antiochian synods $(264,269)$ dealt with the removal of Paul from Samosata from the bishop's seat (Eusebius 1999: VII: 30). His doctrine was described as Monarchianism, a kind of nontrinitarism based on adoptionism (Galtier 1933: 87-88; Grillmeier 1979: 287-289, 418-422; Ortiz de Urbina 1964: 94-100).

Antioch found itself in a complicated situation during the Arianism era. Arius (256-336) proclaimed an explanation according to which Christ-Logos is not eternal and all-powerful like God the Father, but was created by Him out of nothing before the creation of the world. According to these views, Christ was only elevated to the dignity of the Son of God after his resurrection, in recognition of his mission (Stead 1964: 16-31; Möennich 1950: 378-412). The first council of Nicaea (325) strongly condemned Arianism. Antioch was represented at this assembly by a large delegation of bishops (Devreesse 1945: 1-16, 124-128; Grotz 1964).

The Nicene rejection of Arianism resulted in the formation of three theological parties in Antioch. The first, which could be called the "Eusebian party," officially-for fear of Emperor Constantine - did not oppose the decisions of the council, but consistently continued to develop a teaching contrary to the Nicene credo. This group was associated with Eusebius of Nicomedia (died c. 341), who was of great importance at the ruler's court (this bishop baptized the emperor himself in 337) and led the campaign against St Athanasius (c. 295-373), a defender of Orthodoxy (Luibheid 1976: 3-23).

The second group of Antiochians, centred around St Eustatius of Antioch (c. 320-c. 337), fearlessly supported the Nicene Creed and all the canons of the Council. This bishop was an enemy of Arianism and was the first to opt for the expression, " $\Lambda$ ó $\gamma \circ \varsigma-\alpha \nu \theta \rho \omega \pi \circ \varsigma$ " instead of " $\Lambda$ ó Mary. It is difficult to agree with those who suggested that Eustatius was a continuator of the teachings of Paul of Samosata and a predecessor of Nestorius (c. 383-451), because the analysis of the texts of this anti-Arian bishop, despite the inaccuracy in the use of the term communicatio idiomatum, points to his complete orthodoxy (Spanneut 1948). He paid for the defence of orthodoxy by being unfairly accused and exiled to Thrace.

Finally, the third group consisted of faithful Christians who, while recognizing the decisions of the Council of Nicaea, were also obeying the decisions of their bishops. This caused a kind of ambivalence; as it is difficult to find church writers in the 4th century who did not include any trace of Arianism in their texts (Biriukov 2016). 
The 4th century passed in an atmosphere of constant struggle between the supporters of orthodoxy and of heterodoxy. Despite this split, Antioch had great ecclesial authority. Besides, the Council of Nicaea confirmed the supremacy of the Antiochian patriarch over the Churches of Syria, Palestine, Cyprus, Arabia, Mesopotamia, Persia, and India. In the early days, the Churches of Caesarea, Edessa, Nisibis, Seleucia-Ctesiphon, and the distant Malabar also desired close ties with Antioch. In the period from the 4th to the 7th century, the Antiochian patriarchate comprised 11 provinces (metropolises) and 127 dioceses (Devreesse 1945: 305-312).

The first permanent division of the patriarchate: Nestorianism
In the following century, paradoxically when Arianism was fundamentally overcome and began to die out, there was the first permanent split within the Church, a division that arose in the patriarchate of Antioch and left its deepest mark there. The teaching of Nestorius (380-451) became the source of the controversy, as he developed the thesis about two persons in Christ. He began his arguments by ques-

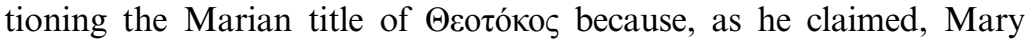

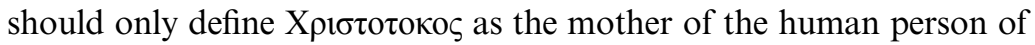
Christ. The turmoil that arose over this teaching awakened the old antagonism and created a new one between the patriarchal schools of Antioch, Alexandria, Rome, and Constantinople. In order to restore religious peace in the country, Emperor Theodosius II (402-450) called a council to Ephesus (431), where "Nestorianism" was condemned. A dogma was also formulated about the existence of two natures in Christ - divine and human - but one divine person, which also justifies the title of the Mother of God for Mary (Wessel 2004: 182-296; Chadwick 1951: 145-164; Jugie 1912; Loofs 1914; Camelot 1951: 213-242; Seleznyov 2010: 165-190).

For many decades, there has been a debate as to whether the theology of the Church of the East is really "Nestorian." Nowadays historians of dogma are of the opinion that Nestorius was, at least to some extent, misunderstood and that he did not in fact express the views that were later attributed to him. He was unjustly banished from his capital and his followers persecuted. The whole dispute over

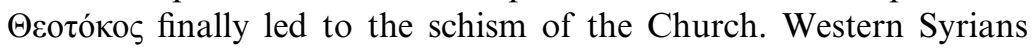
subjected to Antioch eventually adopted the Orthodox (Melkite) Christology of the Council of Ephesus and rejected Nestorius' interpretation. In the East, in the Persian Empire, the opposite was done: The teaching of Nestorius was accepted and the council was rejected. It should be remembered that in the Church of the East, theology was much less developed and the "Nestorians" fleeing from Byzantium had a great influence on this community in terms of Christology and Mariology, especially after the Byzantine emperor closed the Edessa school (Kościelniak 2020a: 80-81).

It is very problematic to use the attribution of "Nestorianism" to 
the theology of the Church of the East, considering that the term "Nestorianism" is understood differently. It seems better to speak of certain "Nestorian" tendencies, and it is even more correct to stress the influence of Antiochian theology as represented by Theodore of Mopsuestia (392-428) and his disciple Nestorius (428-431) on the Church of the East. The official doctrine known as "Nestorian" was adopted by this Church in 484/485, hence its popular name: the "Nestorian Church." Interestingly, Nestorius himself never had any ties to the Persian Church, did not know the Syriac language, and did not preach all the teachings attributed to him as "heretical" (Kościelniak 2020a: 82).

However, the solemn condemnation of "Nestorianism" at the Council did not cause it to fade away with time, as was the case of Arianism. After the closing of the last "Nestorian" institution in the empire - the school in Edessa - this branch of Christianity continued to develop in Persia, in the areas of the former Chaldea (therefore, the "Nestorians" were also called the Chaldeans). The "Nestorians" developed their own rite and adopted the Chaldean language in the liturgy. From Persia, "Nestorianism" passed to India (6th century), China (7th century) and the Turkish and Mongolian tribes in the 10th century (Wessel 2004; Tang 2002; Chung-Hang Chiu 1987; A Nestorian Collection 1972; Yoshiro 1951; Pelliot 1914: 623-644; 1973; Latourette 1929; Vine 1937; Cordier 1917: 49-113; Moule 1940; Hickley 1980). Thus, the first serious and permanent diminution of the influence of the Orthodox (Melkite) Antiochian patriarchate took place.

"Nestorianism" did not mean the end of Antioch's troubles in Christological disputes. A substantial part of the Christians of the Antiochian patriarchate, following the example of Alexandria, adopted "Monophysitism," which is nowadays considered "the final product" of the Alexandrian school (Che 2015: 269). According to "Monophysites," Christ as God has two natures ( $\varphi v ́ \sigma \iota)$ ), divine and human, but does not exist in two natures, because divine nature has completely absorbed human beings. This teaching was preached by Eutyches Presbyter (c. 380-c. 456), an archimandrite of one of the monasteries in Constantinople, who wished to overcome the erroneous theses of "Nestorianism." What was supposed to be a defence of orthodox science has become a new error. No wonder, then, that Eutyches' views were condemned by the patriarch of Constantinople, Flavian (446-449) and Pope Leo I the Great (440-446) in the famous dogmatic letter on the two natures of Christ, Tomus ad Flavianum (Tomus ad Flavianum 1846; Chadwick 1955: 17-34). The patriarch of Antioch, Domnus (441-450), also supported the anti-"monophysical" activities. After the short-term success of "Monophysites" on the so-called "Robber Council" (latrocinium Ephesinum - the Second Council of Ephesus 449) not recognized by the Pope, "Monophysitism" was soon rejected by the

The decisive division: Melkites and "Monophysitism" (the "Jacobite" Church) 
Council of Chalcedon (451), which adopted the theses of Pope Leo I as a model form of Orthodox Christology (Abramowski 1955-1956: 252-287; Weijenberg 1976: 353-398; Šagi-Bunić 1969; Stellers 1953: 158-181; Devreesse 1945: 136-140; Ortiz de Urbina 1953: 233-240; Downey 1961: 461-462; Carrière 1979: 338-357).

The mere condemnation of "Monophysitism," as in the case of "Nestorianism," did not bring the expected results. Eutyches Presbyter found supporters for his claims among the clergy of the Alexandrian and Antiochian patriarchates. However, it is difficult to determine how many, as some researchers claim that this doctrinal dispute was one of the attempts to free Syria and Egypt from the rule of Constantinople. It is possible that "Monophysitism" overlapped the movement of rebirth of Eastern cultures, directed against the domination of Greek civilization. Attempts to separate the eastern provinces from the Byzantine Empire which used religious motives influenced the position of some emperors who were looking for a dogmatic compromise. A classic example of such pragmatics was the

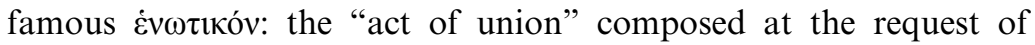
Emperor Zeno (474-491) by the patriarch of Constantinople, Acatius (471-489) and Peter III of Alexandria (477-489), patriarch of Alexandria (died 477). Henotikon, devoid of contentious topics between the followers of Chalcedonian Orthodoxy ("Catholics") and "Monophysites," was close to orthodoxy, but theological silences and the ideas of Caesaropapism were dangerous. This resulted in a protracted conflict with the papacy (Anecdota Monophysitarum 2001: 636-654; Kötter 2013; Chesnut 1976; Salaville 1918: 225-265; 1920: 49-68; Townsend 1936: 78-86). In turn, another attempt to solve the problem, the persecution of "Monophysites," undertaken by Emperor Justinian (527-565), only deepened the resistance of the inhabitants of the East to Greek culture and in the next century made it easier for Muslims to conquer the Byzantine world. The last attempt to reconcile "Catholics" with "Monophysites" before early Arab conquests, undertaken by Emperor Heraclius (c. 610-641) in an administrative way with the help of Ekthesis edict, failed (more about this below).

The consolidation of divisions: three cultural environments of Melkite-Monophysite interactions
As a consequence, the Melkites constantly confronted the followers of "Monophysitism" in three cultural milieus. The first cultural circle was the Christians of Syriac culture, that is, the community organized by Jacob Baradaeus (c. 500-578) known from Greek sources as B ماريفي (البرادعي). The Melkites interacted less often with the "Nestorians" of the East-Syriac tradition in Mesopotamia, although the "Nestorian" patriarch was the most influential Christian leader in the caliphate during the early Abbāsid period. These relations were closely related to the turbulent political history of Byzantine expansion towards 
Armenia. Its inclusion in the empire meant that the Armenians were one of the strongest ethnic groups in the Byzantium. At the end of the 6th century, a major part of the so-called Greater Armenia remained in the Byzantine Empire. The Arab conquests in the 7th century resulted in the loss of many of these lands, but part of Armenia was still under Constantinople. At the end of the 9th century, Byzantium regained much of Armenia, and in the middle of the 11th century all of it was in Byzantine hands. Finally, the third circle of the Melkite-"monophysical" confrontation was the Coptic culture in Egypt. Christians who were faithful to the Chalcedonian Orthodoxy probably suffered the greatest losses there, and the Melkite patriarchate of Alexandria became extremely weak after the conquests, when the Copts took over many of the Melkite Churches.

Anastasius' (491-518) long rule at the turn of the 5th and 6th centuries was very turbulent. This - perhaps the most critical-time in the history of the later Roman Empire was marked by internal and external conflicts, religious disputes, and financial and administrative chaos. (Charanis 1939). From 451 to the death of Emperor Anastasius I Dicorus in 518, the "monophysical" doctrine was officially proclaimed by several patriarchs of Antioch, among whom the most prominent personality was undoubtedly Severus (512-518), who was forced to leave Antioch (the arrival of this patriarch in Egypt is celebrated by the Coptic Church). In just a few years of his ministry, he managed to establish a large "monophysical" hierarchy. However, during the reign of Justinian I (518-527), who was "basically a supporter" of the teachings of the Council of Chalcedon, the imperial administration successfully imposed an official interpretation of the Church in the cities. The expression "basically a supporter" was used because the emperor in the 530s was unsure whether to firmly adopt the Chalcedonian dogma with the Western Church (Rome), or to seek compromise with the "Monophysites" who were so strong in the patriarchate of Alexandria. Without a doubt, his wife Theodora (died 548) played a great role in this dilemma. She had both sympathy for the "Monophysites" and a certain influence on Justinian. That is why the emperor changed his position several times. Nevertheless, Justinian's brutal methods and his interventions in the appointments of bishops, shattered the chances of an agreement leading to the final separation between these Christian communities. On the orders of Justinian, almost all "Monophysical" bishops were expelled from episcopal sees and imprisoned. The "Monophysical" hierarchy was on the brink of extinction. Twentyfive years after Severus' expulsion from Antioch, the "Monophysite" hierarchy was saved by Empress Theodora, who, in "Jacobite" tradition, is considered to be a "Believing Queen" and protectress of "Monophysite" church (Harvey 2010: 209-234). Her policy led first

The Melkite problem: parallel church hierarchies and the process of consolidating "Monophysitism" 


\section{4}

The development of the Melkite Church

to the ordination of two "Monophysite" bishops in 542 and then to rebuilding of the structures of the "Jacobite" church (Pazdernik 1994: 256-281). One of the hierarchies that particularly contributed to the development of this community was the aforementioned Jacob Baradaeus, a fearless supporter of "Monophysitism," who created a solid structure of the so-called "Jacobite Church." Jacob Baradaeus, from 527 to his ordination as bishop of Edessa, stayed at the college in Nisibis, where he received careful education. As a bishop, he recreated the "Monophysite" hierarchy by ordaining about 30 bishops. He led the life of a "nomad bishop." Dressed in rags, not only because of poverty, but also for fear of Byzantine soldiers, he walked across the desert areas of Syria and Cappadocia. He did not have a permanent residence. His lifestyle and travels are reminiscent of the apostolic journeys of St Paul (Vita Baradaei, Land 1875, 364-385). It is doubtful, however, whether he visited as many lands of Asia Minor and Egypt as is claimed in the extensive and legendary literature on his exploits. He was most active in Syria (Honigmann 1951: 142-154; Roey 1953: 339-360; Vööbus 1973: 17-26; Bundy 1978: 45-86; Devreesse 1945: 75-92; Kościelniak 2000a: 94-95).

Considering the solidification of "Monophysitism" and a serious rupture in the community of Eastern Christians, the mentioned attempt of Heraclius to reconcile the Melkites with the "Monophysites" deserves closer attention. The endeavours of this emperor reveal both theological ingenuity and his political realism. Finally, Monotheletism, as discussed below, shows the extraordinary complexity of the interactions between the East and the West and the individual Melkite patriarchates (in the eyes of "Monophysites," as the follower the Council of Chalcedon, Rome was also seen as one of actors of the "Melkite camp"!). However, since the 5th century, "Monophysitism" was not only a simple protest against the Chalcedonians but it also became a developed doctrine (Che 2015: 279).

A missed opportunity for reconciliation? Defeat of the Melkite Ekthesis in the context of the Arab conquest
The rulers of the Byzantine Empire were, therefore, keenly interested in the dispute between the Melkites and the "Monophysites." It is worth stressing one more time that although the emperor officially supported the Council of Chalcedon, in the later period, the Byzantine rulers alternately supported both sides of the dispute, depending on the beliefs of the current emperor. However, the fighting in the 6th century weakened the state, which became especially dangerous in the face of the Byzantine-Sasanian War of 602-628 (e.g. Egyptian "Monophysites" did not want to support the Byzantine imperial forces). This is why Emperor Heraclius decided to ease the fierce dispute and to compromise (he could not even have guessed how helpful it would be to reconcile Melkites with "Monophysites" in the face of the Arab invasion of Syria and Egypt in 634-641!). Heraclius managed to convince the patriarch of 
Constantinople, Sergius I (610-638), to work out a position acceptable to the Melkites and the "Monophysites." The task was made easier by the fact that the patriarch was also in favour of reconciliation at heart, as he himself came from a family of Syrian "Monophysites." Sergius figured out the compromise doctrine. With the help of an Alexandrian "Monophysite," he proposed a formula for "one" action in Jesus, referring to a fragment of Paul's letter to the Philippians (Phil. 2:13). That was the origin of the doctrine that accepts only one divine-human will. According to this explanation, there are two natures in Jesus: divine and human (the diophysical

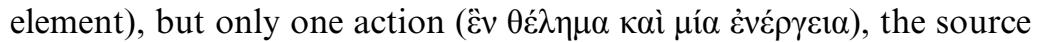
of which is not nature but a person (Monoenergism, the "monophysical" element).

In 633, the patriarch of Alexandria, Cyrus, adopted this doctrine and lectured it systematically, as presented in the famous letter Psephos. Soon he began to forcefully impose this creed on his opponents while sending a letter to Pope Honorius in which he showed the positive effects of reconciliation with the "Monophysites." The Pope, who did not understand the nuances and intricacies of the doctrinal Christological discussions in the East, recognized a new formula for theological reconciliation. However, the patriarch of Jerusalem, Sophronius, the opponent of Sergius, joined the matter by sending a letter to Rome, outlining the dangerous theology of the existence of two actions in Jesus. In this situation, the Pope asked the patriarch of Constantinople to end the dispute. In 638, two years after the Byzantine defeat at the Battle of the Arabs on the Yarmouk River, Emperor Heraclius issued an edict known as the Ekthesis, in which he officially endorsed Monotheletism (Sophronius, Allen 2009; Hovorun 2008: 103-162; Sahas 2009: 120-127).

However, as Phil Booth points out, referring to the chronicle of John of Nikiû, which is one of the most important sources for this period, it should be remembered that the version we have is far from the original. Moreover, the author shows the apologetic nature of many narratives, and the sometimes contradictory information contained therein, which should force us to carefully form our conclusions. It must be assumed that the political alliances that took advantage of the Christological dispute on the eve of the Arab conquests were much more complex, diverse, and ephemeral than it is believed. In-depth analyses of historical sources indicate that these conflicts were not based on simple personal rivalries or solely on a blind pursuit of power. They also resulted from economic reasons, fiscalism, and the defence strategy of the empire-probably taking into account possible religious problems that would result from the re-admission to the communion of Christians previously perceived as heretics. The 730s provide a veritable tangle of polemics and 
Maronites among

Melkites, or the followers of Monotheletism? apologetic arguments that are currently difficult to interpret. In any case, the last years of Patriarch Cyrus, who-according to the classic version of John of Nikiû - was also responsible for the fall of Byzantine Egypt, in fact indicated much more than the rise and fall of various emperors in the turbulent months of 641 (Booth 2016: 539).

The Ekthesis edict, however, also caused serious and long-lasting tensions between Byzantium and Rome. After 11 years of turmoil, Pope Martin I convened the Lateran Synod in 649, which condemned the doctrine of Monotheletism as unorthodox. In response to this act, the Exarch of Ravenna (governor of the Byzantine province established in 584) entered Rome in 653. Monotheletism was officially condemned only about 150 years later at the Third Council of Constantinople in 680-681.

A large number of historical sources indicate that Monotheletism was the official teaching of the Maronite Church, as representatives of this church did not participate in the Third Council of Constantinople (Sophronius 2009; Hovorun 2008: 103-162; Sahas 2009: 120-127). Maronite historians and theologians themselves strongly deny this, stressing that the Maronite Church had no theological problems entering into a union with Rome in the Middle Ages, which consequently brought the teaching of this community completely in line with the Roman Catholic interpretation. The documented Maronite historiography, which started in the 15th century with Ğibrāyīl b. al-Qilā i (1447-1516), strongly stressed the "Eternal Orthodoxy" of the Maronite Church (Douaihy 1993: 167-192). Nevertheless, there have been disputes over the very foundation of the Maronite Church. There are basically four main interpretations. Sceptics say that the establishment of the Maronite church is related to the union with Rome and that its previous history is unclear. Others see its roots in a monastic Monotheletic origin, relying on information from Eutychius of Alexandria and William of Tyre (1127-1135). Still other scholars strongly maintain that the Maronite Church certainly has Chalcedonian monastic roots, as the community was shaped after a fundamental wave of Christological controversy. If this theory were to be accepted, the Melkite origin of the Maronite Christians from the patriarchate of Antioch would have to be automatically recognized. Finally, some authors essentially in the past quite radically attributed the apostolic origin of the patriarchate of Antioch exclusively to the Maronite Church (Rouhana 1988-1989: 215-259; Suermann 2002b: 146). Considering the fact that for several decades some Maronite historians (such as Karam Rizk) have been suspending their judgment regarding the Monotheletism of the Maronite Church (Suermann 2002b: 147), this topic will not be elaborated on. It seems that various sources and later interpretations allow us to assume that the Maronite 
community - like churches in various regions - experienced a tension between the Chalcedonian Orthodoxy and other Christologies. Nevertheless, we are not able to accurately recreate the course of these tensions, or the extent of the controversy and individual polemical stages up to the 11 th century.

In hindsight, the Monergism was a failed attempt to reconcile the Melkites with the "Monophysites," and indeed was a by-product of the split caused by the Chalcedonian definition of faith. The painful divisions between the Melkite and "monophysical" communities in Egypt, Syria and Palestine have not been resolved. Moreover, in addition to orthodoxy and "Monophysitism," there are some indications that a new interpretation of Monotheletism became popular among a certain group of Christians of the patriarchate of Antioch (the disputed case of the Maronites in Lebanon). On the other hand, this ancient division originated from various tensions and crises in the relations between Rome and Constantinople (Ohme 2008: 308-34; 2015: 27-61; Winkelmann 1979: 161-82; 2001). All this, in the context of the Arab invasion, weakened the position of Christianity in the Middle East and was one of the reasons for its systematic decline.

Since the Arab conquests have been mentioned, it is worth looking at the condition of Christianity among the Arabs. In the first centuries of Christianity, the Arabs not only inhabited the Arabian Peninsula, but were also present in the Roman zone known as Limes Arabicum (Dussaud 1955: 21-47) and in the Syrian Desert sometimes described by historians as the Syro-Mesopotamian region (Dussaud 1955: 71-118). Chronologically, Christianity began reaching the Arabs in the 2nd century and was strengthened in the 3rd and expanded considerably in the 4th and 5 th centuries, covering a large geographical area: the Roman province of Arabia and the border areas with Persia as far as Yemen and South Arabia. Christianity reached many nomadic tribes (Ryckmans 1956; Shahid 1971; 1984; 1888; 1989; Kościelniak 2000a; Nau 1933; Devreesse 1942: 263-307; Charles 1936; Müller 1967). Mediaeval scholar Amr b. Baḥr al-Ǧāḥiz attested to a significant number of Christians among pre-Islamic Arabs. He states that Christianity spread among most Arabs, with the exception of the northern Arab tribal group Mudar. However, the Mudar themselves who live in al-Hirā are Christians. In addition, according to al-Ğāhiz, Christianity was adopted by the kings of the following Arab tribes: Laḩm, Gassān, Nağran, Qudā'a, Tayy, and numerous other clans and tribes (Ğạhiz 1926: 15). It is worth remembering that recent research indicates a privileged position of the elite over a group ("tribe") in the pre-Muslim Arab world. They played an important role not only in political alliances with Rome (Byzantium) or Persia, but also influenced the religious spaces of

The geography of Arab Christianity in the 6th century 
particular Arab communities (Fisher 2018: 489-521; 2014a: 273-292; 2014b: 279-295).

Al-Hārit b. Ğabala (c. 528-569), one of the most eminent rulers of the Arabian state of Gassānids, is mainly known for his connections with the Byzantine Empire (although it seems he was related to the Monophysite church). The archenemy of this Gassānid ruler was the Arabic, (and probably "Nestorian") Lahmid king Al-Mundir III (c. 505-554) with whom Al-Hārit b. Ğabala has been in conflict for at least 25 years. This war changed the position of the conflicting kingdoms in favour of Al-Hārit and his successors (Turek 2019: 73-95). Pro-Byzantine sentyment of Al-Hārit b. Ğabala and proSasanian orientation of Al-Mundir III is well testified by Procopius of Caesarea (Procopius 2008: 1.17.45-48; 2.16.5; 2.28.12-14; 8.11.10). There are some indications that these kingdoms have for many decades established a very deep aversion to each other, regardless of the policy of the great powers that supported them. This is evidenced by the conflict of AD 546, when both Al-Hārit and Al-Mundir III "waged a war against each other by themselves, unaided either by the Romans or the Persians" according to Procopius' account (Procopius 2008: 2.28.12).

Melkites among Arabs

The situation on the eve of the Arab conquests
Christianity among Arabs before the rise of Islam was relatively well organized. Individual churches had their own hierarchy, metropolises, bishoprics, and sometimes monastic communities. The divisions associated with the Trinitarian disputes were undoubtedly the weakness of this Christianity. Arab Christians in the Persian sphere of influence belonged primarily to the "Nestorian Church." In turn, "Monophysitism" spread among Arabs in Syria and Mesopotamia, as well as in southern Arabia in the sphere of Aksum influence. It is difficult to say to what extent the Arabs belonged to the Melkite Church, especially since, as mentioned, the Byzantine emperors interchangeably supported the Chalcedonian confession of faith and the theological positions of the "Monophysites" (Trimingham 1979: 125-307). It is believed that the Arabs belonging to the Melkite Church lived mainly in Syria, Palestine, and the Byzantine-Persian borderlands, but Bishop Silvanus, who was sent by Emperor Anastasius I Dicorus to the kingdom of Himyar in 512, was connected with "Monophysitism" (Shahid 1989: 401-402). The condition of the Melkites among the Arabs is difficult to describe unequivocally because not a single Christian Arabic manuscript from before Muhammad's activity has survived, which could show the theological activity or the liturgical life of the Arab Melkites (Kościelniak 2004: 69-76; 2003: 329-342; Graf 1944: vol. 1: 27-51).

The golden age of the Antioch patriarchate ended in the 6th century, when it finally fell into three independent organizational units: the "Nestorian," beyond the borders of the Empire, the 
"Monophysical" ("Jacobite") persecuted by the Byzantines in Syria, and the Melkite, that is, those faithful to the Chalcedonian Orthodoxy and the emperor. Since the council of Ephesus, the dividing line between the East and the West, the Semites and the Greeks, was permanently drawn. The only positive aspect of religious disputes was the incredible development of theology which shows rich Christological terminology (Šagi-Bunić 1962: 499-514; Camelot 1962; Sellers 1954).

Regarding the proportion of the divided Christians, there was a "balance of power" on both sides-both Orthodoxy and "Monophysitism" had around 50\% of followers (Kościelniak 2000b: 41). Culturally, however, the cities were more Greek, while in the villages the Syrian element dominated. The beginning of the 7 th century also saw the decline of the coastal area and the Bedouinization of Syria (Kennedy 1985: 181). Due to internal divisions and the Muslim conquest of Syria, patriarchate of Antioch systematically fell into decline in the following periods. As time passed, fewer and fewer sources about Christian Antioch appeared. The former glory and authority of this patriarchate are gone.

\subsubsection{The patriarchate of Alexandria}

It is well known that Alexandria, founded in $332 \mathrm{BC}$ by Alexander the Great (356-323 BC), was one of the most significant centres of Hellenistic culture (the capital of Egypt from AD 311). Greeks,

The grounding of Christianity in Alexandria Egyptians (Copts), and Jews were the most numerous groups among the multilingual population. The city grew extremely quickly, becoming the largest Mediterranean city in the Ptolemaic period and a thriving centre of economic, political, and cultural life.

According to a tradition dating back to the 4th century, the founder of the bishopric in Alexandria was to be St Mark the Evangelist (5-68). However, the life of this saint is little known to us due to the fragmentary nature of the sources (Eusebius 1999: II: 24.1). It is known that he was a companion of St Peter (died around 64). However, whether he was the first bishop and founder of the Church in Alexandria is difficult to say. Unfortunately, the information from the apostolic writings is so sparse and challenging to systematize that the larger history of Mark is full of assumptions and not certain facts. It is interesting that his activities were not mentioned by St Clement of Alexandria (c. 150-c. 215) or Origen (c. 184-c. 253). The sources are almost silent about 2nd-century Alexandrian Christianity. The History of the Patriarchs of Alexandria only lists the dates of the consecration and death of the ten patriarchs from 68 to 188, without giving any information about them until the contemporary of Origen, the 12th patriarch-Saint Demetrius I 
The Melkite and Coptic traditions of martyrdom

The formation of the patriarchate
(188-231) — during whose rule the first state-organized persecution of Egyptian Christians took place (Muqqaffa' 1904: 1: 51-56).

Both the Melkite and Coptic traditions refer to many Alexandrian martyrs of the first centuries AD. The persecution of Christians in Alexandria was repeated with some regularity (e.g. during the reigns of the emperors Nero [54-68], Septimius Severus [193-211], Decius [249-251], Valerian [253-260], and Diocletian [284-305]). Christians did not receive a status similar to the Jews, who were exempt from burning incense in front of the imperial statue. Hence, the situation of Egyptian Christianity during the first three centuries resembled a sinusoid; periodic persecution was intertwined with times of respite and relative tolerance (Milne 1924: 69-72; Jouguet 1947; Healy 1905). The bloodiest persecution took place during the reign of Diocletian. The prisons were full of Christians, and the accounts of their martyrdom in Eusebius (Eusebius, Maier 1999: VIII) and in The History of the Patriarchs of Alexandria (Muqqaffa' 1904: 1: 119-136) reveal shocking, sophisticated torture techniques. It is difficult to list all the martyrs of this persecution here. Many of them are spoken of by the Coptic synaxaria and the lives of the saints. While it is possible to argue over the enormous numbers of victims given by various church sources (some even cite 140,000-800,000 martyrs), there is no doubt that the period of persecution had a strong impact on the life and mind of the Copts, so much that they chose to adopt a calendar according to the era of the martyrs (Anno Martyrii), which for them has almost the same meaning as the chronology of the birth of Jesus Christ (Anno Domini) (Papaconstantinou 2006: 65-86; Atiya 1978: 28; Grigss 1990).

It was mentioned that the first bishop who was relatively well known from the sources was St Demetrius I. In time, the Alexandrian bishops gained many powers over the surrounding bishops, and then over all of Egypt and the surrounding regions. Alexandria's domination in the area was facilitated by the tradition of the apostolic origin of the bishopric, the existence of a missionary base in Alexandria, the extensive theological activity of many Alexandrian bishops, and the political and administrative importance of the city and a significant percentage of Christians. By the 3rd century, the bishop of Alexandria had great prerogatives over all of Egypt: he had the right to consecrate or remove from office all the bishops of the country on the Nile, convene synods, and interfere in the disciplinary affairs of the entire Egyptian Church (Attila 2001). These rights were confirmed by the Council of Nicaea, but they only became the "Patriarchal privileges" in the 6th century. At the Council of Chalcedon (canon 28), Alexandria lost its second place (after Rome) to Constantinople. Popes Leo the Great (440-461) in 452, Nicolas the Great (858-867) in 866, and Leo IX (1049-1045) in 1052 opposed Chalcedon's decisions regarding the order of patriarchal capitals, opting for the Nice arrangements. It was 
only at the Council of Lateran IV (1215) that the facts were approved, granting Constantinople a place before Alexandria. Going back to the pre-Chalcedonian period, in the 4th century, the Alexandrian patriarchy covered all of Egypt, Thebaid, Libya, and Pentapolis with nine metropolises and 100 bishoprics (Kościelniak 2004).

One of the greatest gifts of the Egyptian Church to all Christianity is

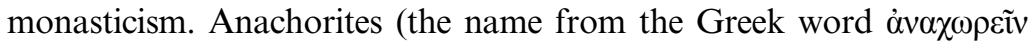
[to move away]), or hermits living far from people, devoting themselves to prayer, mortification and work, set a new example of Christian perfection. In the times of persecution of Christians, the number of people open to this path of holiness increased greatly. The most famous ones, who also created the spiritual and organizational foundations of the monastic movement in Egypt, were St Paul of Thebes (c. 227 c. 341), St Anthony the Great (251-356), St Ammonas (4th century), and Macarius of Egypt (300-391). Hermit life was mainly developing in the Arab deserts (Egypt). Relatively quickly, anachoreticism turned into coenobitism or Coenobitic monasticism (from the Old Greek word

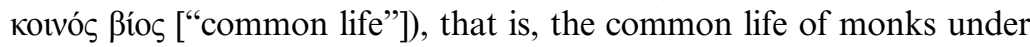
the leadership of an abbot according to a specific rule. Such a form of hermitic life was initiated by the aforementioned St Anthony the Great, but its creators were St Pachomius the Great (c. 292-348) and St Basil the Great (330-379), who noticed the spiritual and material benefits of living together with hermits. However, Egyptian monasticism had many ideological faces (Goehring 1999: 196-220). The idea of religious life quickly spread to Palestine and Syria, mainly thanks to St Hilarion the Great (291-371). Monasteries were then founded in Armenia, Persia, and Mesopotamia. It is estimated that around the middle of the 5th century there were 80,000 monks of the Basilian rule and about 50,000 the monks of the Pachomian rule. The monastic life was soon regarded as the higher form of realizing the Christian vocation. From the 4th century on, monasteries in the East played an extremely important role, so much so that it is impossible to understand what the Oriental Churches were and are today without taking into account their importance (Wipszycka 1986: 17-47; Bacht 1956; Kłoczowski 1964: 56-61; Sastre Santos 1997: 69-75).

The importance of the Church of Alexandria in antiquity stretched far beyond Egypt as early as the 3rd century. The research undertaken by many theologians played a leading role in the history of Trinitarian and Christological doctrine at the first general councils in Nicaea and Ephesus. The activities of the patriarchs, especially St Athanasius of Alexandria (328-373) contributed to the popularity of the patriarchy. In turn, thanks to St Demetrius, the exegetical traditions of Alexandria were formed, which, with some simplification, were called the "Alexandrian school" until recently. (Bardy 1937: 65-90; 1942: 80-109; Van den Broek 1996). On the other hand, one

The high position of the Church of Alexandria in antiquity 


\section{2}

The development of the Melkite Church

should rather stress the theological tradition of Alexandria, because in the field of patristic exegesis there has been recent criticism of the Myth of the so-called Alexandrian-Antiochian Schools of Interpretation (Slade 2019: 155-176). In turn, St Dionysius the Great (247-264), a disciple of Origen, played an important role in theological disputes, combating the errors of Sabellianism, modalism and Epicurean materialism (Baumkamp 2014: 65-66; Colson 1924: 364-377). Saints Alexander I of Alexandria (c. 318-c. 328) and Athanasius of Alexandria (328-373) became famous as staunch opponents of Arianism (Rolandus 1977; Lamiński 1969; Gaudel 1929: 524-539; Bernard 1952) and St Theophilus (385-412) fought paganism in Egypt (Leppin 2003). Finally, St Cyril of Alexandria (412-444) became famous for his texts against "Nestorianism," thus creating one of the most outstanding theological systems among the Greek Church Fathers. Perhaps the greatest merits in the field of Christology were achieved by St Cyril, who explained that the hypostatic union in Jesus Christ does not consist in "indwelling" God in man, but in the real union of two natures in the person of the Son of God (Liébaert 1951: 159-174; 1970: 27-48; 1977: 49-62).

The drama of division: "Monophysitism"

Melkites and "Monophysites": the double hierarchy of the Alexandrian patriarchate
Under Patriarch Dioscorus I (444-451), there was an expansion of "Monophysitism" in Alexandria. Dioscorus himself, as an archdeacon, accompanied his predecessor Cyril of Alexandria to the Council of Ephesus in 431. Adopting from his bishop the aversion to the "Nestorian" concept of the existence of two natures and two persons in Christ, he fell to the other extreme, knowing the doctrine of the miaphysitism or theory of "one nature of the Word of God

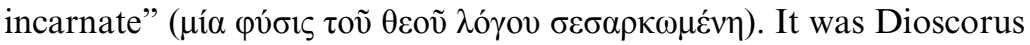
who led the aforementioned Ephesinum latrocinium in 449, violently rehabilitating the creator of Eutyches' "Monophysitism." However, two years later he was removed from office at the third session of the Council of Chalcedon (451) and sentenced to exile by Emperor Marcian (450-457). The Coptic Church declared him a saint (Lebon 1946: 515-528).

After Dioscorus was removed, the patriarch's throne in Alexandria was taken over by a supporter of orthodoxy: Patriarch Proterius of Alexandria (451-457). Most of the Coptic clergy, however, opposed the provisions of Chalcedon, which sometimes were interpreted as part of an expression of increasing Egyptian nationalism towards the imperial policies of Byzantium. Consequently, two hierarchies arose in the Church of Alexandria. The first, Melkite, or "royal" (Greek) hierarchy with strong ties to Constantinople, firmly adhered to the orthodoxy formulated at the Council of Chalcedon. The second, native hierarchy was strongly associated with Egyptian nationalism; therefore, it was also referred to as Coptic ("Monophysite"). Initially, the Byzantine secular 
authorities did not treat these differences seriously. But in reality, this separation was deeper than what Constantinople believed. It manifested in the brutal murder of Patriarch Proterius of Alexandria in the absence of a Greek garrison in the city. After many disputes, Emperor Zeno realized that there was no hope of defeating the Alexandrian "Monophysites" by force. It was then that people started looking for a solution to religious problems with the help of the above-mentioned Henoticon. However, by avoiding difficult issues in principle, this "act of union" did not represent the true position of both sides, and, in addition, Rome joined in, imposing an excommunication on one of the main initiators of Henoticon, Acatius. Nevertheless, until 518 the pact constituted a pattern of agreement to which the opposing parties alluded.

During the reigns of the emperors Justin (518-527) and Justinian (527-565), the conflict escalated, because these rulers strongly (although paradoxically not always consistently) supported the Chalcedonian option. The Egypt of this period was marked by great administrative disorganization, exacerbated by religious differences. Both sides strengthened their positions: the Melkites had the support of the imperial army, while the Coptic "Monophysites" had their own troops of monks. Justinian, wishing to facilitate the control of the situation in the Egypt, divided it into two provinces: Lower Egypt (the delta and Alexandria) and Upper Egypt (Tebaida). In fact, this decision contributed to an even greater disagreement, additionally stirring up a spirit of rivalry between the prefects. The Copts' hostility to the Melkites is illustrated by the fact that the emperor was forced to send soldiers to the Melkite patriarch of Alexandria, Apollinarius (551-570). He was guarded like a prefect by an army unit. This patriarch was given the right to collect direct taxes for the maintenance of churches. It is easy to imagine the reluctance of the Copts who had to pay taxes for the Melkite clergy. The apogee of this policy was the massacre of Egyptian "Monophysites," carried out on the orders of Apollinarius, who wanted to appease the protesting Copts (Milne 1924: 108-111; Evans 1996; Mazal 2001; Meier 2004; Haase 1993; Moorhead 1994; Boojama 1981: 202-209; Amelotti 2001: 469-491; Winkelmann 1979: 161-182).

On the other hand, Justinian contributed to the expansion of some monasteries. During the Melkite-"Monophysite" unrest, Empress Theodora, Justinian's wife, secretly professed "Monophysitism," defending it with all possible means. In fact, Justinian and Theodora's relations with the "Monophysites" were highly peculiar. In this religious confusion, Justinian himself, at the end of his life, turned to the "monophysical" sect of aftartodokets, who proclaimed

Escalation of the Melkite-Coptic conflict during the reign of the emperor Justinian 
The situation of the Melkite Church of Alexandria on the eve of the Muslim conquest that the body of Christ was not subject to decay and was immortal (Széll 2013: 1-8; Evans 2002; Harvey 2010: 209-234; Che 2015: 280).

From the later point of view of the Melkites, Alexandria fought much worse than Antioch against "the wave of Monophysitism." The division of this ancient patriarchy was more dramatic than in Syria. The "Monophysite" Copts, joined by the Ethiopians, constituted the overwhelming majority. The Melkite patriarchate had no chance of development, and its activity has been minimized over time. It was increasingly overshadowed by the rising authority of Constantinople that patronized it. On the other hand, the Melkite patriarchate of Alexandria was systematically weakened by the ambitions of the Copts, who were more and more distant from the Greeks and totally devoted to their "Monophysite" patriarch. These factors significantly weakened it after the Muslim conquests. This was the price of the Melkite Church of Alexandria for its allegiance to the resolutions of the Council of Chalcedon (Vries 1964: 437).

Thus, we come to the central figure of 634 , or "the starting point" of our history of Melkites in Egypt, that is, the usually negatively assessed activity of the Patriarch of Cyrus, one of the creators of Monotheletism. This patriarch — as already mentioned — was a supporter of "the monoenergist plan" suggested by Sergius, the Patriarch of Constantinople. The double failure of Cyrus was an unsuccessful attempt to unite the Miaphysites and the Chalcedonians around Monoenergism, which evolved into Monotheletism (Bronwen 2010: 321-322), and certain humiliating stipulations, to which he subscribed as the prefect and entrusted with the conduct of the war (Butler 1978: 234). Cyrus also signed a final peace treaty with Arabs that surrendered Alexandria and Egypt on 8 November 641 before his death in 642 (Butler 1978: 254).

In his detailed analyses of the whole context of Cyrus' activities (634-641), Phil Booth poses fundamental questions about the value and the way of reading the sources from this time, especially the chronicles of John of Nikiû (Jean de Nikioû 1883). Chapters 116-120 are particularly important, as they describe the months from the death of Heraclius to the ascension of Constantine III (from January to November 641), which were accompanied by political and religious events with significant political and religious consequences. For centuries, historians have regarded these turbulent years as a period of exceptional factionalism between the descendants of Heraclius' two wives, Fabia Eudokia (610-612) and Martina (613-641). However, it is worth noting that these rivalries were accompanied by polemical and apologetic texts, which were included in later chronicles. Hence, factionalism was far more ingrained than blind ambition, family pride, or moral disapproval. It seems that the two sides represented in the sources also had different strategies on 
the two pressing issues of the period, namely their defence policy towards the Arab conquests and their positions on the opponents of the Chalcedonian doctrine (Booth 2016: 510).

\subsubsection{The patriarchate of Jerusalem}

In the 1st century, the Judeo-Christian Church in Palestine consisted of a number of communities that were difficult to define precisely. From the outset, however, these local churches regarded Jerusalem as their centre and point of reference. Tradition considers James the Just, the first bishop of Jerusalem, to have been martyred around AD 62/69. The serious destruction of Jerusalem following the Jewish uprisings against Rome in the late 1 st and early 2 nd century brought the importance of this city into decline. The city felt particularly painful consequences after the suppression of the Bar Kokhba uprising (132-136). Jerusalem was practically demolished and the Roman city of Aelia Capitolina was built in its place, which the Jews were forbidden to enter under the penalty of death. This ban was not lifted until 333. However, starting from the end of the 3rd century, the city began to lose its strategic importance and the Romans withdrew their troops from it (Mor 2016: 468-485).

The persecution of the followers of Judaism also affected the Christian community, as it had Aramaic (Judeo-Christian) roots, and the Romans did not always understand the distinctions of Jewish parties. The serious weakening of Jerusalem's position also echoed among Christians. Gradually, Jerusalem's position was overshadowed by other Christian centres, notably Constantinople, Antioch, Alexandria, and Rome.

However, the tolerance for Christians during reign Constantine the Great (306-337) increased pilgrimage movement to Jerusalem. As a city closely related to the activities and death of Jesus, it acquired a special cult status. For this reason, in 325, the First Council of Nicaea granted the bishops of Jerusalem the honourable title, but not the status of a metropolis (then the highest rank in the Church "it may appear astonishing that in the earliest times it [Jerusalem] was only a suffragan see to the great Church of Cæsarea" (The First Council of Nice 2020: VII).

While the date 395 is usually given as the beginning of the Byzantine Empire, historians disagree on the exact starting date of the Byzantine period in Roman history. Many believe that the first "Byzantine emperor" was Constantine I (reigned 306-337), who moved the imperial capital from Nicomedia to Constantinople in 330 (Leszka, Wolińska 2011: 31-32). It is debatable whether this decision was the foundation of the new state. This decision could be seen as part of the process of marginalization of Rome that had already

Byzantine Era: expansion of basilicas 
46 The development of the Melkite Church

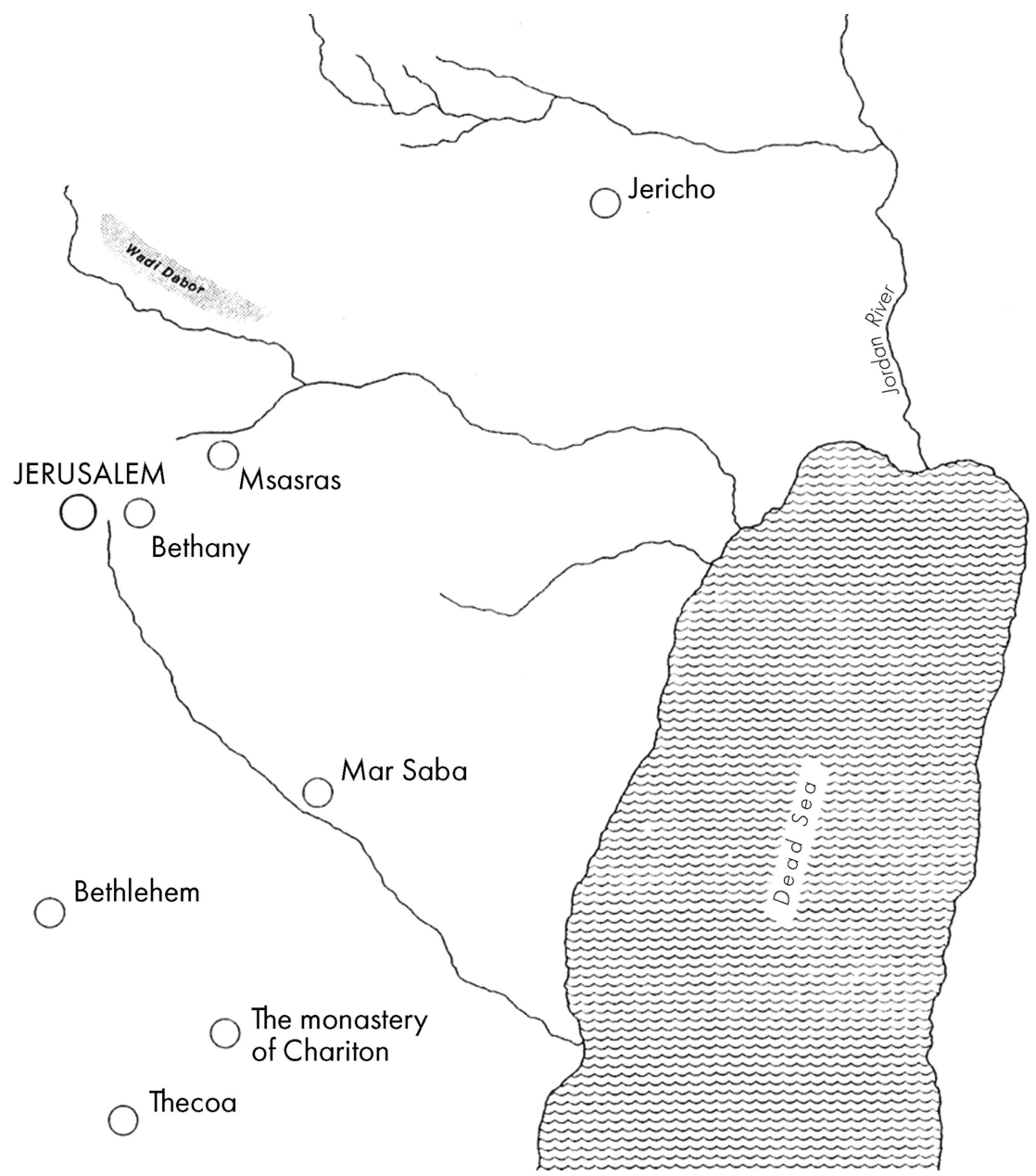

Map 2.1 Pillar of the Jerusalem patriarchate: The most important monasteries in the Palestinian desert between Jerusalem and the Dead Sea.

begun because the city ceased to be the capital during the reign of Diocletian (284-305). However, adopting an earlier date for the rise of the Byzantine Empire seems more appropriate for Jerusalem.

Starting in the year 324, during the reign of Constantine the Great (307-337), Jerusalem became the most important religious centre of the empire. At that time, the construction of numerous churches and other buildings began, the Basilica of the Holy Sepulchre was erected and defensive walls were most likely built then. Crowds of pilgrims began to come to the city, and many monasteries were built in the vicinity (the monasteries of St Euthymius, St Theodosius, and St Sheba). This investment meant much more than tangible buildings. There emerged a 
new Christian paradigm of Christian pilgrimage and a new territorial concept of the empire as a particularly privileged place (Elsner 2000: 181-195; Onişor 2013: 183-198). In turn, the reign of Justinian I the Great (527-565) brought new religious projects, such as the church called Nea, which was established in honour of the Blessed Virgin Mary.

It has already been mentioned that until the middle of the 5th century, Jerusalem was only an ordinary bishopric belonging to the patriarchate of Antioch, and was subordinate to the metropolis of Caesarea Maritima. No wonder, then, that as the religious importance of this city increased, Jerusalem began to apply for a patriarchy status. The history of the Jerusalem patriarchy is marked by a specific ambivalence. On the one hand, Jerusalem had always been proud of its apostolic origin, while on the other hand, it was elevated to the rank of patriarchy relatively late: at the Council of Chalcedon (451). However, until its rank was raised in the early Byzantine period, it had been a small provincial city for three centuries. As such, it could not gain recognition for a long time, even though its apostolic origin was beyond any doubt (Vailhé 1910: 325-336).

The first bishop to have metropolitan claims citing the apostolic succession of his capital was St Cyril of Jerusalem (c. 350-386). Sozomen described the dispute between this saint and Acatius, the bishop of Caesarea (died 366), about the metropolitan rights. Cyril justified his claim by stating that he was "the representative of the apostolic throne" (Sozomen 1890: 274-276). Although the bishop of Jerusalem had been under the authority of the metropolis of Caesarea since Council of Nicaea, he enjoyed exceptional dignity as a guardian of the Holy City (Wipszycka 1994: 71-72, 240). Finally, at the Council of Chalcedon, at which Jerusalem and Antioch concluded pro bono pacis, "the city of Christ's resurrection" was proclaimed as a patriarchate. The only, extremely suggestive argument that Juvenal of Jerusalem (422-458) had at his disposal was that Church had arisen in this Holy City. This bishop had stubbornly and for a long time fought for this position of Jerusalem. In 449, he supported Dioscorus I, patriarch of Alexandria, and obtained from Emperor Theodosius II, who sympathized with "Monophysites," the supremacy over the bishoprics in Phoenicia and Arabia. As a result of the Chalcedonian Agreement, Phoenicia and Arabia returned to Antioch, while Jerusalem received three Roman provinces.

Jerusalem had also been involved in "monophysical" disputes. Juvenal, who ultimately opted for the Chalcedonian Christology, Conflicts with was expelled from Jerusalem shortly after the council by the "Monophysites" and took refuge in Constantinople. His place was taken by the Coptic monk Theodosius of Jerusalem (451-453). Juvenal returned to Jerusalem only after the military intervention

The small city with great ambitions and claims

Rise of the patriarchate 


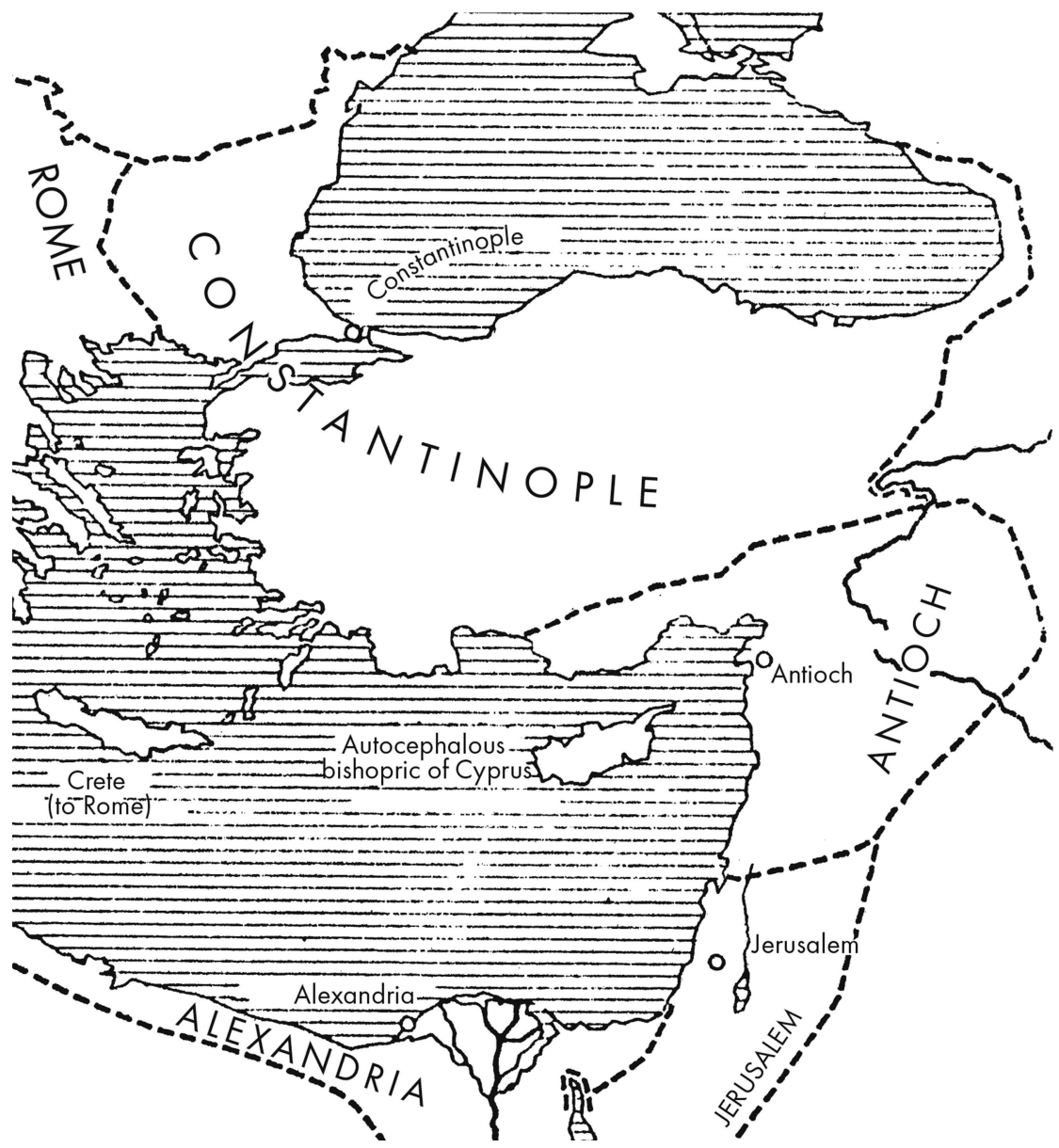

Map 2.2 Patriarchates after the Council of Chalcedon (451).

Consequences of the Persian invasion in 614 of the emperor in 457. It was then that he was re-recognized as patriarch by Pope Leo I the Great (Honigmann 1950: 209-279).

Although Jerusalem had become an arena for fighting between the Melkites and the "Monophysites," the hierarchy had not been split in this patriarchy. This was due to the fact that the patriarchy arose very late, and it was the council that condemned "Monophysitism." Moreover, in terms of territory, it was the smallest of all patriarchates, and it was relatively easy to introduce a uniform denomination within its borders. Thus, the Jerusalem patriarchate had a one-man cast: a patriarch usually faithful to the Chalcedonian Orthodoxy Catholic ("Melkite faith").

One of the greatest tragedies was experienced by Christian Jerusalem in AD 614. Chosroes II (591-628) destroyed Jerusalem, 
especially Christian sanctuaries, killed thousands of Christians and captured the Melkite Patriarch of Jerusalem, Zacharias (from 609 to 632), other Christians, and the relics of the Holy Cross. The basilica of the Holy Sepulchre was burnt and demolished (Ben-Ami, Tchekhanovets, Bijovsky 2010: 204-221; Foss 1975: 721-747; Foss 2003: 149-170; Maksymiuk 2017: 109-125). In the event of the abduction of Patriarch Zacharias, St Modestus of Jerusalem (632-634) became the new leader (as locum tenens) of the Melkite Church of Jerusalem. This extraordinary person came from Cappadocia, but as a young man he was a slave in Egypt. Modestus succeeded in becoming an ascetic on Mount Sinai. Then he became hegumen (abbot) in the monastery of St Theodosius near Bethlehem. In 614, after the conquest of Jerusalem by the Sassanids, he became the administrator of the Jerusalem patriarchate in place of Zacharias, who was captured and deported to Persia. He rebuilt many churches, and renovated abandoned monasteries in the desert. In fact, he was the deputy of the absent patriarch, and Modestus of Jerusalem was not elected patriarch until the return of the relics of Holy Cross in 630 . He died shortly afterwards, in 634 or 630 (Wilkinson 2002: 15-16; Esbroeck 1984: 107-108). 


\section{The situation of the Melkite Church in the first centuries of Islam (634-750)}

Phenomenon of Arab conquests
Celebration of Pyrrhic victory and the first disregarded signal
The rapid Arab conquests are among the most astonishing phenomena in history. At every step, their pace, scope, and great disproportion between the means used and the spectacular successes achieved are surprising. From 634 until the end of the 7th century, they systematically succeeded in conquering vast areas. The mighty powers of Byzantium and Persia with their regular army were losing battle after battle to the Arabs. Muslims travelled thousands of kilometres in small groups, surprising their enemies with successful actions of their troops and took advantage of the dissatisfaction of local Christians with Byzantine policy (Donner 1981; Glubb 1963; Hill 1975: 32-43). Only a few decades passed from the time of the war with Byzantium and Persia to the establishment of a stable and strong Muslim state. The Melkite Church in the Middle East was put to a new historical test (Bousquet 1956: 37-52).

\subsection{The Melkite Church and the Arab conquests}

After exhausting battles with the Sassanids, arrangements with the defeated Persians guaranteed Byzantium the restoration of the borders from 591, which were favourable to Constantinople, and the return of the relics of the Holy Cross. Emperor Heraclius (c. 610-641) regained the most sacred symbol of Christianity and transported it first to Constantinople (14 September 629) and then to Jerusalem. Here we begin to have some chronological problems. It is possible that Heraclius appointed Modestos as Melkite patriarch of Jerusalem on the very day of the return of the Holy Cross to Jerusalem, namely on Palm Friday (21 March) in the year 630 (Theophanes 1885: 204-205; Esbroeck 1984: 107-108). The emperor, in the company of his wife Martina, re-deposited the Christians' most holy relics in Jerusalem, where they remained for only five years (Garitte 1960: 50-54; Histoire d'Héraclius 1904: 69-70; Wojciechowski 2003, 16-17; Frolow 1953, 88-105). This event is known in many traditions as the Restitutio Sanctae Crucis (Drijvers 2002, 175-190). No-one realized DOI: $10.4324 / 9781003253006-3$ 
then that the confrontation of these two empires, disastrous for Byzantium, and then for Persia, prepared the entry of new conquerors into the territory of the Middle East and Africa: the Arabs (Fiey1987: 96-103; Baynes 1913: 659-666).

However, at this time, when Heraclius was already triumphant over the Persians in the year 629, the imperial court was informed of an attack by an Arab group on the frontiers of the empire in a region east of the southern shores of the Dead Sea. This event went down in history as Ma'rakah Mu'ta on the al-Baqā border. In fact, it was a skirmish between the Arab forces created by Muhammad and the Byzantine troops along with their allied Arab Christian Ghassanid vassals. The attack did not arouse much interest among the Byzantines. This skirmish appeared to resemble one of many less significant Bedouin attacks for which the region had been famous for centuries. How unpredictable the vagaries of history are! The aforementioned attacks began a systematic struggle between the Muslim world and the Byzantine Empire until the fall of Constantinople in 1453, which systematically changed the contexts of the existence of the Melkites.

\subsubsection{The Melkites and the defeat of Byzantium in Syria and Palestine}

The reconstruction of the events of the Syrian conquest is still full of chronological ambiguities. An attempt to recreate it on the basis of Arabic chronicles meets with serious reservations. Based on the late compilations of great historiographers, inconsistent dating is revealed, a small set of literary topoi-which the authors used to construct a large number of battles - is uncovered and the tendency for more and more details to appear in later sources is observed.

Therefore, it seems more appropriate to use the term "the Syrian/ Mesopotamian campaign of 634-637," within which many uncertain events might have taken place. This campaign, however, had specific consequences and an important meaning. It is of course necessary to show the traditional Muslim point of view while discussing this campaign. A critical evaluation of the Muslim sources leads to a more general description as an element of the campaign (634-637) cannot be unambiguously evaluated. Nevertheless, specific studies of the early Islamic sources lead to the conclusion that it is certainly easier to interpret the functions of particular topoi than to determine the facts about the early conquest (Kościelniak 2020b: 24-40).

In 634, Arab troops led by Yazīd b. Abī Sufyān (d. 639) invaded Palestine. On 4 February in Datin, their meeting with Greek forces was hastily arranged by the Byzantine commander $d u x$ and candidatus Sergius. The Byzantines were defeated, and the victorious

Problems with reconstructing the conquest of Syria

The first contact between the Melkites and the Muslim army in 634 
Arabs began plundering the country. It was perhaps the first Melkite experience with a Muslim Arab army. However, it was an experience with the invader resulting in material losses. The Melkites, who had to bear the new costs of the invasion, did not realize that with the arrival of the Arabs, the era of the Muslim Middle East began. At this stage, none of the Melkites considered the beliefs of the invaders and only concerned themselves with labelling them heretics or ungodly Saracens. This was expressed in the synodal letter of Sophronius (c. 560-638), the patriarch of Jerusalem. The opinion of this hierarch is of particular importance because it dates back exactly to the year 634 . The patriarch is full of hope in defeating the enemy and asks God the Almighty to support the Byzantine emperor in the fight so that the ruler can "break the arrogance of the barbarians" or "break the arrogance of the Saracens." These enemies "have risen unexpectedly against us [Melkites, Greeks]" showing a "cruel and animal manner [of] thinking" and "evil and heretical audacity" plundering everything (Sophronius 1863: 3197). The testimony breathes conviction into the great abilities of the emperor who defeated the Sassanids so spectacularly. It talks about stopping the Arab invasion in the same way, although Sophronius gives no details about the invasion itself, except the general statement that Arabs "plunder everything" (Schönborn 1972: 89-90; Sahas 2006: 34-35).

However, the hopes placed by the Melkites in the power of the Byzantine Empire were crushed. Greeks began frantic preparations to recapture the lost lands. The Byzantine troops transferred to Hawrān (southern Syria) to protect the extremely strategic route to the north, but they were unable to stop the Arab victorious march, the reason being the Muslim troops from Iraq, led by Hālid b. alWalīd (d. 642) and Abū 'Ubayd (d. 634), which rushed to help Yazīd b. Abī Sufyān (Ațīr 2001: 252-255; Balādhurī=Beladsori 1866: 110-112; Tabari1991a). The Muslims soon became the owners of central Syria. The Arab troops struck the imperial army, and in the Battle of Ağnādayn on 30 July 634 they achieved a great victory over the Byzantines. Greek troops withdrew from Damascus in an attempt to save Homs and Antioch (Goeje 1900, Kaegi 1992a: 265-280).

In the context of the Arab exploration of the region, Sophronius also took up the subject of the Saracen invasion in his Christmas sermon in 634. The patriarch stressed that "the army of the godless Saracens has captured the divine Bethlehem" and "bars our passage there, threatening slaughter and destruction." Melkite patriarch of Jerusalem was convinced that if Christians were to live as it is pleasing to God, they "would rejoice over the fall of the Saracen enemy" (Sophronius 1863: 3201-3212). Thus, the first meetings with Muslim Arabs were marked by the fear of the Melkites, who 
perceived the invaders as barbarians (Sahas 2006: 34-35). Arabs were initially seen as plunderers and believed to have ties to the Jews. The Melkite interpretation of the Arab invasion at this stage was dominated by the theme of divine punishment for the sins of Christians (Guenther 1999: 363-378).

It is significant that Islamic sources mention Christian Arab tribes that fought on the side of the Byzantines. During this early period of conquest, Muslim Arabs fought against the Arab Christians, and treated them harshly (Qāộ̄ 2016: 89).

Arab forces continued their expansion. The momentary control of the situation by the Greeks after the victory over part of the Muslim units (the battle near Güta in the spring of 635) did not change the balance of power in the region. Soon, after a six-month siege, in September of the same year, the army of the caliph entered Damascus. Abandoned by the imperial army, the city's population surrendered. The terms of this first and such a significant surrender became a model for the future for Muslims on how to make deals with other conquered cities. The content of this pact was passed on to us by 'Ahmad b. Yahyā al-Balādurī. Notwithstanding the critical remarks on the topoi of such messages, it is basically an account of the earliest agreement of this kind, and therefore, due to "the pioneering nature of this treatise," it is worth quoting in full: "In the name of Allah, the Beneficent, the Merciful. This is given by Khalid bin Al Waleed [sic] to the people of Damascus. When the Muslims enter, they (the people) shall have safety for themselves, their property, their temples and the walls of their city, of which nothing shall be destroyed. They have this guarantee on behalf of Allah, the Messenger of Allah, the caliph and the Muslims, from whom they shall receive nothing but good so long as they pay the Jizya" (Balāduri=Beladsori 1866: 121; English translation: Hitti 1964: 130).

The Byzantine emperor Heraclius realized the drama of the situation and sent his army to the Homs area. The defeat at Leba in July prompted the Arabs to leave Damascus. Muslim troops near the confluence of the Jordan and Yarmūk rivers defeated the imperial troops in the famous battle, one of the most decisive ones (for more see: Bailey 2004: 17-22). The Byzantine army was scattered, and Heraclius himself, who was waiting in Antioch for the outcome of the battle, hastily left for Anatolia. Thus, in July 636, Byzantium lost one of its most beautiful provinces, which it never managed to fully regain. "Peace be with you Syria - what a beautiful land you will be for your enemy!": such words were allegedly uttered by Emperor Heraclius when he left this rich province forever (Balādhurī 1996: 1; Nicolle 2009: 51).

A lot of explanations have already been made about the collapse of the Byzantine defence of Palestine and Syria against the Arab

"Final farewell to Syria" and the first official contact between the Melkite elites and the Muslim rulers 
invasion. Usually, the weakening condition of the empire is emphasized, exemplified by financial problems, exhaustion after the war with the Sassanids and military, ethnic, and religious miscalculations (Kaegi 1992b). It is possible that the resistance to Monotheletism in the Jerusalem patriarchate was also the reason why Heraclius failed to defend this region. It is known how much Constantinople was concerned with this attempt (the compromise formula of Monotheletism) to reconcile "Monophysites" with Chalcedonian Orthodoxy (Sahas 1999: 96-97).

Finally, Arabs became the lords of Syria. Damascus capitulated a second time, and neither city offered serious resistance to paying the tribute. Caliph 'Umar I (634-644) personally came to take possession of the conquered countries. He travelled to Jerusalem in a Bedouin dress on a camel, where he was received by the Melkite Patriarch Sophronius. The bishop of Jerusalem, surprised by the poor clothes and the crude behaviour of Caliph 'Umar I, apparently remarked about him in Greek to the servant: "Really, this one is the abomination of desolation spoken of by the prophet Daniel standing here in a holy place" (Theophanes 1885: 212). It is possible that this information given by Theophanes retrospectively presents a certain Byzantine and Melkite topoi. It is also probable that this fragment shows the differences in the cultural level between the invaders and the defeated. The Melkites, though defeated militarily, were wealthier and more economically developed.

On the other hand, there are also interpretations of Sophronius' diplomacy as "not simply protecting the city physically." Sophronius was supposed to protect Jerusalem from becoming a Jewish city (Sahas 1999: 85; Sahas 2006: 33-44).

Melkite leader: negotiator with the caliph?
Regardless of the biting remarks of Sophronius to Caliph 'Umar (which are historically questionable), it is significant that the Muslim historiography ascribes to this patriarch the negotiations of the status of Christians in Jerusalem. For centuries, 'Umar's assurance of security for Christians from Aelii (Jerusalem) or al- 'Uhda al- 'Umariyya has attracted the attention of historians with different views on their authenticity for centuries (Munshar 2012; Awaisi 2000: 47-49). It is difficult to say in what measure Sophronius actually negotiated the conditions for the functioning of Christians in the new reality. As the head of the local church, he most likely met with the caliph, but some information provided by Muslim sources contains traces of later solutions. For example, Sophronius was to invite the caliph to pray there, but 'Umar refused because he feared that he would threaten the church's status as a Christian temple (this information appears to be of late origin when it refers to a law developed by Muslim schools in the 8th century). More important than the facts of this event 


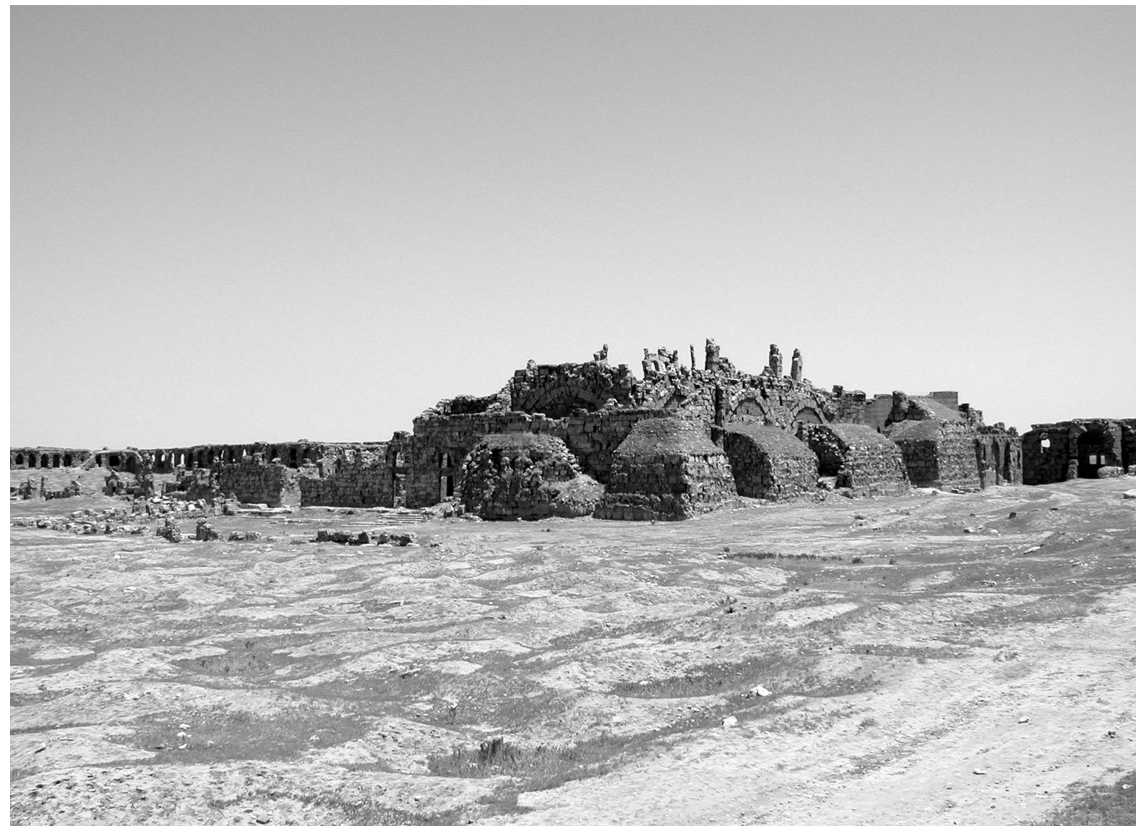

Figure 3.1 The remains of the magnificent Melkite St Sergius cathedral in Sergiopolis (today Resafa). It probably became the most important pilgrimage centre (after Jerusalem) in the Byzantine Orient (5th-7th centuries) favoured by the local Arabs, especially the Gassanids (the author's private collection).

is the significance of 'Umar's Assurance for Muslim historiography (Wāqid al-Wāqidī, al-Balādurūi, Ibn al-Ațīr). Various versions of this assertion (al-Ya'qūbī, Eutychius of Alexandria, al-Ṭabarī) do not make it easier to establish the degree of authenticity. Debatable arguments are used quite often in endless discussions. For example, considering Kitāb al-Futūh aš-Šàm as the oldest testimony of this encounter contrasts with the opinion of Western historians, who consider the work to be a later text falsely attributed to 'Umar b. Wāqid al-Wāqidī (c. 747-823), dating it to around the time of the Crusades; some scholars believe a small portion of the text may be traced back to al-Wāqidī (Landau-Tasseron 2000).

Contemporary research also excludes the possibility of finding the origin of the Pact of 'Umar in the event of 'Umar's Assurance from 637. Today scholars commonly accept that the 'Umar Pact is apocryphal because the content of this text responds to the social and political problems that arose between Christians and their Muslim rulers in the middle ages. However, although the Pact of 'Umar was probably written around 200 years later, such traditions are interesting because they link the figure of the Melkite Patriarch 
Consequences of the Muslim conquest of Syria for divided Christians

Poor protection of one of the richest provinces of the empire

The successes of the Muslim army and the controversial Melkite patriarch
Sophronius with the negotiation of the law that involved all Christian denominations (also "Monophysitism" and "Nestorianism").

It is significant that it was from Jerusalem that 'Umar I issued instructions on the relief of the last Greek troops. The Melkites witnessed the effective cleansing of the area of the remains of Byzantine troops. Only Caesarea resisted until 640. By the caliph's voice, management of the newly conquered territories was entrusted in 639 to Mu'āwiya b. Abī Sufyān (661-680). The conquest of Syria was the first great success of the Muslims. This led to a break in the land route connecting Egypt with other provinces of the empire. In terms of confession, the different Churches found themselves under the rule of new masters who were not interested in the dogmatic differences between Christians. The long-term consequences of the Muslim conquest of Syria also contributed to the victory of the Arab cultural element in Asia Minor (Constantelos 1972: 325-357; Ahrweiler 1962: 1-32).

\subsubsection{The fall of Byzantine Egypt and uncoordinated Melkite interactions}

Since the earliest times, Egypt had appeared to be a unique country. It was an inexhaustible granary, an entryway to other areas of Africa, a cultural and scientific base and a producer of high-class material goods. The Byzantines, like all previous occupiers, used the wealthy country as much as possible, the more so because, in addition to economic benefits, it had an extremely strategic position in the foreign policy of Constantinople. Even so, Egypt was not sufficiently prepared to repel the Arab invasion at the time of the war in Syria (Kaegi 1982: 111-115). The Greeks made insufficient safeguards, and therefore Egypt immediately fell into the hands of the Muslims. The Arab conquest of the country on the Nile was not accidental, but took the form of a systematic war (In studies on the conquest of Egypt, Butler 1978 is still very helpful).

The icon of the Muslim conquest of Egypt was the cunning 'Amr b. al- 'As al-Sahmī (c. 573-664), who, thanks to the famous meanders of his correspondence with the caliph, was able to fulfil his desire to conquer the country on the Nile. This clever commander had been on many trade trips to Egypt in his youth. Working in caravans taught him all of the most important routes and cities in this country. The conquest of the Pelusium (al-Faramā') opened a series of Arab victories on Egyptian soil. Quickly another attack on the Babylon Fortress (today Coptic Cairo) followed. During this siege in AD 640, a strengthened Muslim force (but still half the size of the Greek forces) completely defeated the Byzantine army at the Battle of Heliopolis, known today as 'Ayn Šams (Tabarī 1989: vol. 13). 
After this severe defeat, the viceroy and Melkite patriarch of Egypt, Cyrus (631-642), unsuccessfully tried to bribe the besiegers. In the end, he was forced to negotiate and talk with the Arab emissary, Ubadah b. al-Ṣāmit (d. 665), who was a companion of Muhammad and a respectable leader of the Ansar tribes' confederation. As in all deals with the conquered population, here too, the Muslims were firmly set on three conditions: either the defeated accept Islam, pay a large ransom or they would continue the fight to the end so that God would decide on whose side he was. Cyrus chose to pay tribute and went to Alexandria to present the terms to Heraclius. Basileus was so indignant at the patriarch's conduct that he accused his governor, the bishop, of treason and banished him (Theophanes 1885: 212).

On 6 April 641, the Babylon fortress fell after the murderous siege, and on 13 May, the inhabitants of the city of Nikiû (Naqyūs) were captured and slaughtered (Balādhuri=Beladsori 1866: 213). Almost the entire delta was in Muslim hands with the exception of the fortified metropolis of Alexandria, which was guarded by a military garrison of 50,000 soldiers. The first Arab attack was repulsed with the help of catapults that were modern at the time (Jean de Nikioû 1883: 450). In this situation, 'Amr b. al-'Āṣ al-Sahmī withdrew from the siege of this fortified city and began the pacification of Upper Egypt.

Events took a turn for the worse after the death of Emperor Heraclius in February 641. In Byzantium, his grandson Constans II (641-668) took power. This inexperienced young man fell victim to the insidious policy of Patriarch Cyrus, whom he restored to favour. Cyrus, expecting to be able to govern the country regardless of whether Egypt was ruled by the Greeks or the Arabs, sought at all cost to sign an agreement with the Arabs. Writing about three centuries later, Agapius, the Melkite bishop of Mambīğ, described in more detail the controversial policy of Cyrus from Alexandria. According to this account, Cyrus was to leave Alexandria and come to the Arab camp. He stood before 'Amr b. al-'Āṣ al-Sahmī and announced that the agreement they had concluded was not broken because of him, but because of the intervention of Emperor Heraclius. He asked him to restore peace on the terms of the first treaty. 'Amr b. al-'Ạs al-Sahmī replied to Cyrus that he did not intend to grant his request. "I don't trust you," he supposedly answered, "because you tricked me the first time. Besides, you are asking for the impossible, because we have just conquered all of Egypt and we will never leave it." So, Cyrus would return to Alexandria, having gained nothing (Agapius 1912: 474).

The treaty signed on 8 November 641 between the Byzantine emperor, who was represented by the previously compromised Cyrus,

The controversial "success" of the Melkite patriarch and the loss of Egypt by the Byzantine Empire 
and 'Umar handed over Egypt to the Muslims. Under the contract, Cyrus agreed to a tax of two dinars per person, and a land tax to be paid in kind. Moreover, Cyrus assured the Arabs that he would not allow the return of the Byzantine army, which had evacuated Alexandria in September 642. 'Amr b. al-'Āṣ al-Sahmī triumphed. He promptly sent information about his success to Medina (Jean de Nikioû 1883: 463). It is worth remembering that in our attempts to reconstruct the events of the first half of the 7th century in Egypt, we rely heavily on the chronicles of John of Nikiû (Jean de Nikioû 1883). Nevertheless, modern scholars are critical of the only surviving version, as the original text was composed in Coptic, but has survived only in the 17 th-century Ethiopian translation from a lost Arabic abbreviated manuscript (Booth 2016: 510).

During the Muslim conquest, remembering the Byzantine persecution, the Copts did not engage on the side of the Greeks. Perhaps this was the will of the "monophysical" hierarchy of Egypt. Ibn 'Abd al-Hakam (803-871) states in his Futūh miṣr wa'l magrab wa'l andalus ("The Conquest of Egypt and North Africa and Andalusia") that the Coptic bishop of Alexandria encouraged Egyptian Christians to be passive towards the Arab conquest of Egypt (Ibn 'Abd al-Hakam 1922: 58-59; Coptic sources on the conquest of Arab Egypt are presented by Amélineau [1899]).

While the "Monophysite" Copts gained tolerance, the rules of the Egyptian administration did not change economically, as the Arabs used the highly profitable Byzantine tax system. By the end of 645, the city's inhabitants overthrew the Muslim rule. The Byzantine Empire rushed to their aid by sending 300 ships under the command of General Manuel, of Armenian origin (7th century). Alexandria was in possession of the Byzantine Empire, and the Greeks made forays into the depths of Egypt (Balādhuri=Beladsori 1866: 221). However, luck did not favour the imperial troops this time either. At the Battle of Nikiû, the Arabs dealt a severe defeat to the Byzantines. At the beginning of 646, Alexandria fell into Arab hands for the second time - this time forever. The new city administrators demolished the fortified walls so that the events of 645 would not be repeated in future.

Consequences of Egypt's separation from Byzantium for the Melkites
The conquest of Egypt had serious consequences for Byzantium and the Melkite Church. First, the fall of Egypt practically left the Byzantine provinces of North Africa undefended. Second, the Greeks lost an extremely wealthy province that was the state's granary and source of great income. Finally, in the ecclesial aspect, the Melkites remained practically without support from the emperor. They had to come to terms with many unfavourable actions of the Coptic Church. 


\subsection{New rules of functioning of the Melkite patriarchates}

A consequence of the Arab conquest of Syria and Egypt was the inclusion of Antioch, Jerusalem, and Alexandria into a foreign Muslim empire. Apart from the recovery of Antioch by the Byzantine Empire in 969-1084 and the period of the Crusades, the Muslim annexation was an act of forever separating the three ancient patriarchates from the Christian world. The gradual process of the Melkites losing the status of the dominant confession in the Levant began. To this day, it is a painful element of the collective memory of this community. This is all the more understandable when we consider how deeply rooted Melkite Christianity was in Syria and Lebanon. It was perfectly evidenced by the extensive research by Metri Haji-Athanasiou, who published his work in ten volumes (Athanasiou 1977-2002: 1-9/2).

\subsubsection{Political ramifications for the Melkites and other Christian denominations}

During the first years after the Arab conquests, the "Monophysites" and "Nestorians" did not suffer losses as a result of the change of government in the Levant. However, this cannot exactly be said about the Melkites. While there had been several massacres of Christians and damage to churches during the Syria and Palestine conquest, there was no indication of any restrictions or the persecution that would follow. The Melkites, however, who had a privileged position in the empire during the Greek rule, were not received favourably by the new authorities. Their situation became very awkward and often tragic. The Muslim authorities consistently suspected them of being in contact and conspiring with Byzantium, and the Melkites living in the more central regions paid dearly for Byzantine victories (Troupeau 1999: 325). On the other hand, in the 1st-century Hijra, Muslims usually did not forcibly convert defeated peoples to Islam, as shown by reports on the termination of hostilities (Hill 1971: 34-52). Islam quickly found itself in a paradoxical situation: conversions reduced the number of taxpayers (Edde, Micheau, Picard 1997; Ducellier 1996).

Although in principle Muslims were not forcing conquered nations to convert to Islam in the first period of their reign, there were some attempts to convert Christians according to Melkite historians Yūsuf Nașrallāh (1911-1993) and Rašīd Haddād (1929-). These researchers rely on the fact that several centuries after these events, one of the icons of Muslim thought, Ibn Haldūn (1332-1406), mentioned that Caliph 'Umar sent the Prophet's companions to explain al-Qur'ān to

The weakened Melkites: the development of the "Jacobite" and "Nestorian" Church

The first examples of Islamization of Christians 
Melkite religious buildings in the 1st-century Hijra

New social realities of the Melkites

\section{0}

The situation of the Melkite Church

the Syrians. Since Christians were also among some of the tribes of Arab nomads, Arabs were advised to see them as Muslims. AlBalādurī (died 892) states that Caliph 'Umar wished the Tagglib (which was probably the largest and most powerful of the Arab Christian tribes at the advent of Islam) do not to baptize their children again (Nasrallah, Haddad 1996: 40).

Acts of surrender between Muslim conquerors and individual cities usually guaranteed Christians the possession of churches. Many sanctuaries and monasteries remained in the hands of the Melkites (Nasrallah 1985: 1-2: 37-58, 3-4: 264-276). The great flourishing of the sanctuaries that took place in Apamea and Antioch in the 6th century ceased in the 7 th century. It seems that this was not caused directly by prohibition of the new government, but resulted from the general, difficult political situation after the Byzantine-Persian struggle. In any case, new churches were built in Damascus. Religious buildings were also erected in Southern Syria: in Dayr Ayyūb, a trace of the lintel from 641 remained; in Kāfir, the sanctuary of St Gregory in 652; and in 668 the consecration of St Elias in Ormān. In 662/663 the Christians of Mādabā dedicated a mosaic to the Virgin Mary in the church devoted to her. Churches also appeared in new Muslim-funded cities, such as Bassora and Fuștat (Michael le Syrien 1901: 2: 476; Fiey 1993: 970-974).

Melkite Christians in the 7th century constituted the vast majority in Syrian cities. Muslims at that time primarily occupied houses and neighbourhoods abandoned by those who remained in the Byzantine military service (Nasrallah, Haddad 1996: 41). Arabs, settling the captured cities, were not always happy to live in a new place. Often, as nomads who were taught to live in large, open spaces, they felt locked in an urban setting (Nallino 1950: 113; Sauvaget 1967: 1-49).

The forms of public life had undergone some modification. The entire civil administration was preserved, and the defeated population had its tribunals and municipal institutions, in which Greek was mostly spoken. A certain innovation in relation to the Byzantine times was the disappearance of the Melkite preference. Each Christian community was under the sovereign rule of its own religious leaders. Paradoxically, the Muslims gave the "Jacobites" autonomy that they had not enjoyed in Byzantine times. It is estimated that at the end of the 7th century (at the end of the 1st century of the Hijra), Muslims accounted for approximately 200,000 of the four million people in Syria. Generally speaking, in the Umayyad era, despite the restrictions imposed on the "People of the Book," Christians took part in political and cultural life, as evidenced by the fact that the caliph's palace was open to both Christian and Muslim poets (Lammens 1921a: 120-122). The best example is the Christian (Melkite?) poet al-Ahțal al-Tagglibī (c. 640-before 710), the panegyrist 
to the court of the Umayyad Caliph 'Abd al-Malik b. Marwān (685-705). In his three main qașīdas, we observe a role in giving and affirming the Umayyad legitimacy of power. It is quite a peculiar situation when a Christian portrays the caliph as a brave warrior, leading war steeds in military campaigns against Christian Byzantium. It cannot be ruled out that the apotheosis of Abd alMalik is a "counterweight" to his defeat with the Byzantines during the Second Fitna in 680-692 (Pinckney 2016: 150).

After 661, power in the Muslim state was taken over by the governor of Syria, Mu'āwiya b. Abi Sufyān (661-680), the founder of the Umayyad dynasty, which represented Sunni Islam. The Sunnis recognized the caliph as the head of state, supreme judge, and chief, with great religious authority. The caliphs, in the name of God, were to see to the proper application of tradition (sunna), power ( $\mathrm{hukm}$ ), Qur'ānanic punishments ( $h u d \bar{u} d)$, prescriptions (farā'iḍ), and law $(h u q \bar{u} q)$. The caliph, however, did not have the divine authority to make laws or to pronounce them. He headed the Muslim umma as the supreme spiritual and secular headship. According to the unanimous opinion of Sunni theologians, he was ultimately responsible only to God. This implied the necessity of absolute obedience of the faithful to the caliphs. It was believed that those who disobeyed them would suffer punishment in this life and in the future (Crone, Hinds 2003; Lammens 1930; Arnold 2000; Busse 1969; Nagel 1981: vol. 1-2). Christians were necessarily included in such a system, being limited by both the power of the caliph and legislation related to the Pact of 'Umar.

However, initially it was not a very painful change for the Melkites. The Umayyad caliphs abolished many of the traditional Bedouin modes of government, freeing the state from archaic tribal organization. In this way, on the earlier Byzantine foundation, a new state was created, where Melkites experienced in bureaucracy worked in administration. Initially, there were even paradoxical situations. For example, in Syria the Byzantine fiscal system was preserved, in which the majority of officials were Melkites. In the first years, Greek and Byzantine coins with the image of the cross were still used in the administration. When Mu'āwiya minted gold and silver coins without a cross in AD 660, the local people refused to use them (Diehl, Marçais 1936: 201-202; Caetani 1912: 453; Nasrallah, Haddad 1996: 43; Karalevskij 1924: 595).

In Egypt, it turned out relatively quickly that the new masters were not more favourable to the Coptic Church than the Byzantines in terms of fiscal oppression. The Arabs did not directly take over the Byzantine tax system (Hussein 1982: 16). The Arabs demanded high wages for their relative tolerance. The above-mentioned negotiations of Cyrus in Babylon in fact contained the foundations of the Muslim

The caliph's prerogatives and Christians
Christians and the fiscalism of the caliphs 
tax system in Egypt and, for this reason, it should be called the "treaty of Misr" (Morimoto 1979: 96; more details 71-99). Taxes were imposed on Christians: the common one called a tribute, and jizya, or poll tax. The latter had to be paid by all those who were able to work. Soon after the conquest of Egypt in 641, the governor, 'Amr b. al-'Aș al-Sahmī, obtained a staggering sum of 200 million gold dinars from taxes imposed on Christians. His successor increased this incredible amount by two million (Atiya 1978: 71-72). Although the migration of the rural population was caused by many factors (Hussein 1982: 159), the Muslim system of taxes also played a role in this process. These were the phenomena inherent in the transformation of the Muslim community from a "Bedouin-type society" to "the empire society" (Lapidus 1982: 49-72). Egypt, which until the time of the Muslim conquest had been the richest province of the Byzantine Empire, also became a source of great income for the new lords. The Umayyad caliphs and then the Abbāsid caliphs ruled the country through prefects and financial authorizing officers who were directly subordinate to them. To prevent Egypt from becoming independent, the prefects were changed every two years.

This was the reason why Egypt was governed by about 100 prefects during the 226 years from the conquest to the advent of the Tulunid dynasty. In his short period of administration, each of the prefects sought to collect the highest taxes from the Copts to meet the caliph's growing needs and to accumulate wealth. This policy had disastrous consequences for the Coptic Church and especially for the faint Melkite community. The fiscalism of Egypt's administrators relied on continued tax increases; for example, in the years 705-868, the rates of the poll tax and the land tax were doubled five times. No wonder the Copts protected themselves from oppression by converting to Islam or by leaving the villages where they were registered, moving to other areas where no-one knew them. The extent of the problem is evidenced by the fact that as early as AD 715 the obligation to have a special passport was imposed on Christians wishing to move, with a penalty of 10 dinars for failing to have one, and in 723 the Copts were forced-under the penalty of amputation-to wear a lead seal around their necks and a tattooed lion on their hand (Troupeau 1999: 357; Morimoto 1981; Gascou 1983: 97-109; Kościelniak 2002a: 203).

\subsubsection{Ambivalence: two types of treatment of the Melkites}

The world of two pragmatists
Various options began to clash over the attitude towards Christians in Islam. First of all, Muslims adhered to the principle of tolerance. This was due to several reasons. First, Christians paid huge amounts of tax, which gave Arab conquerors quite a comfortable income. Second, during this period, Muslims were in the minority and 
culturally inferior to the well-educated Syrians. Finally, during the period of the intensive expansion of the empire under the rule of $\mathrm{Mu}$ 'âwiya, the Arabs were interested in peace in the provinces under their administration. It is, therefore, not surprising that $\mathrm{Mu}$ 'āwiya relied mainly on the Syrians. The Arab chronicles of this period praise the loyalty that the people of Syria felt for him (Ṭabarī 1987). On the other hand, the belief in the uniqueness and universal nature of Islam stimulated Muslims to spread their religion. Thus, it cannot be said without qualification that the Muslims of the 1st century of the Hijra did not undertake any Islamization campaigns. In some cases, local Muslim authorities favoured conversion to Islam. During the reign of Caliph al-Hišām (724-743), some cities, such as Homs, were partially Islamized. Even then, the more fanatical Muslims demanded a ban on public displays of crosses (Michael le Syrien 1901: 2: 431-432).

As for the territories of the patriarchy of Jerusalem, it is difficult to establish the dates and pace of the Islamization process in the early Muslim period. We have no evidence of massive Islamization in this region during the 7 th and 8 th centuries. From Muslim sources it is clear that Muslims had been present in large numbers in Samaria since the 10th century. Basically, researchers distinguish three sources of systematic Islamization of Palestine. First, it was the result of the immigration of Arab Muslims from the Arabian Peninsula, but much less so than in the case of Egypt (Levtzion 1990: 296-298). Second, the Palestinian borderlands were inhabited by Arab Bedouins from the Banū Laḩm, Banū Ğudām, and Banū 'Āmilah tribes, who professed Christianity (in some part the Melkite orthodoxy) and converted to Islam after the Arab conquests (Levy-Rubin 2000: 261). Finally, a proportion of the Muslim population descended from the Samaritans who converted to Islam in the early Muslim period, largely as a result of difficult economic conditions (Levy-Rubin 2000: 267).

Thus, in the 7th century, there was essentially no spirit of disagreement between Arab Christians and Muslims. For example, the Caliph Mu'āwiya b. Abī Sufyān (661-680) was a tolerant and liberal ruler. In 661, he announced the rise of the caliphate in Jerusalem in the presence of a large number of Arabs. Then he prayed in churches: on Golgotha and under the invocation of the Blessed Virgin Mary (Bagatti 1968, 115-116).

The period of relative tolerance towards the Melkites lasted until the end of the 7th century (Karalevskij 1924: 594). The growing hostility between Byzantium and the caliphate during the reign of Justinian II Rinotmetos (685-695; 705-711) also resulted in tightening the policy of the Muslim authorities towards the Melkites who

Some examples of the early manifestations of intolerance towards Melkites: 'Abd alMalik and al-Walīd I usually were considered to be supporters of Basileus by Muslims. 
On the Arab side, the Caliph 'Abd al-Malik b. Marwān (685-705) reigned and entrusted the provincial administration to two Arab commanders. They were al-Hağğāğ b. Yūsuf (c. 661-714), who ruled Persia and Arabia, and Muhammad b. Marwān b. al-Hakam (died 720), the caliph's brother, who ruled over Mesopotamia, Armenia, and Afghanistan. That is why Muhammad b. Marwān became famous for his cruel methods of returning Arab Christians from the Tagilibit clan to Islam. It was on his order that $\mathrm{Mu}$ ad, the Taglib leader, was burnt to death after refusing to convert to Islam (Michael le Syrien 1901: 2: 431-432; Gilman, Klimkeit 2016: 88; Gil 1992: 134-135). For the same reason, many other martyrs of the Melkite and "monophysical" denomination, mentioned by Bar Hebraeus and Michael the Syrian, also died (Bar-Hebraeus 1890: 121; Michael le Syrien 1901: 2: 431-432). Taking into account a context wider than the Melkite Church, that is, the condition of all the Christians of the Levant, it is worth noting that al-Hağğāğ b. Yūsuf made life difficult for the "Monophysite" Christians in Armenia, where the local Church had been without metropolitan bishops for 18 years. Also at this time, the Coptic Church in Egypt suffered persecution (Muqqaffa' 1910a: 3, 67-68). 'Abd al-Malik b. Marwān even ordered the crosses to be removed from public view and introduced many other anti-Christian laws (Michael le Syrien 1901: 2: 475).

In 705, the Caliph al-Walīd I (705-715) ascended the throne. As the Arab historian al-Mas 'ūdī reports, he exercised power in a way unknown to his predecessors, and was extremely autocratic and fanatical: "he was a ruthless despot, brutal and unjust" (Les praires d'or Meynard, Courteille, vol. 5: 361). He forcefully introduced his father's administrative reform, ultimately replacing Greek with Arabic in offices and official letters (Michael le Syrien 1901: 3: 481). Only the numbers were Greek (Theophanes 1885: 240). The caliph adopted a policy of persecution. During this period, the Melkites also lost St John's Basilica in Damascus to the Muslims (for details see Section 2.3.1).

A special case of the Ğarāğima
While discussing Melkite-Muslim relations, one cannot overlook the special case of frontier Christians, whom Arab historians call Ğarāğima. They came from the city of Ğurğūma, in Amanus (Ğabal Lukkām) and the vicinity of Antioch (the area between Bayās and Būqā). Syriac historiography describes them as Gargūmaye $(\kappa, \pi \ddot{i})$. Since the 19th century, scholars have believed that the Christians of Sarāğima were the people that Byzantine sources call the Mardaites. Rather, they now see them as indefinite Christians; we do not know whether they were "Monophysites" or Monotheletes who gained a semi-independent status in the early caliphate. They certainly played an important role in the wars between the caliphate and Byzantium. Greek sources confirm that the reign of Caliph 
Mu'āwiya b. Abī Sufyān (661-680), Emperor Constantine IV (668-685) used the Mardaites (Ğarăğima?) to destabilize the frontiers of Arab Syria. Historians have established that after the Muslim conquest of Syria, many of them emigrated to the territory of Byzantium. Nevertheless, many remained in northern and central Syria. Their status was an exception to the rule. The Garāğima could not only preserve their Christian faith, but did not pay the giziyya (a per capita yearly taxation on non-Muslims) or participate in military expeditions in the Muslim forces (Canard 1965: 468-469; Chalhoub 1999: 91-95).

The case of the Garāğima is all the more unique when taking into account the development of Muslim law, which gradually began to require Christians to distinguish themselves from Muslims with their clothing or special signs. The Ğarăğima were relieved of this obligation because they agreed to spy for the Muslims. Due to the failure to fulfil this obligation, the Caliph al-Walīd I (705-715) sent a punitive expedition against them in 708. However, after conquering the fortress, Hurğūma prevented the slaughter of Christians and allowed them to dress as Muslims. Ğarăğima were also allowed to participate in military expeditions and had the right to some loot. We do not know why these Christians were treated in a special way by the Umayyads (Ferré 1988: 72-73).

The Ğarăğima have disappeared very mysteriously from the history of the region. One of the few traces that still exist today is the name of one of the districts of Hama, hayy al-ğaräğima. Unfortunately, nothing is known about the Garāğima after the mid-9th century. Some historians find this "disappearance" a "disturbing" fact (Cahen 1970: 248). One of the explanations is based on the hypothesis of the old assimilation of the local Ğarăğima community with Shi'ite immigrants of the Nuayris Ismaili movement (Cahen 1970: 243-249). On the other hand, it is interesting that many modern Maronites derive their origin from the Ğarăğima/Mardaites, as evidenced by some oral traditions (Moosa 1969: 597-608).

The policy of Caliph Sulaymān (715-717), brother of al-Walīd I, shows the great religious commitment of this ruler to Islam. There have been dismissals of Christian officials from the administration. The aversion to Christians in certain Muslim circles continued to deepen. Caliph 'Umar II (717-720) introduced two new laws to the detriment of Christians: a ban on a Christian bearing witness against a Muslim and a ban on praying out loud and using knockers (Michael le Syrien 1901: 2: 489; Caetani 1912: 1243; Zayāt 1949: 161-251). Mika Rubin analysed two policies, that is the policy of "Umar II and the policy of the 8th century, which established and assigned limitations for the "People of the Book" to "Umar I (634-644). Despite the variety of measures that were used, their goal

Melkites in the crucible of interreligious and interconfessional problems 
was one and the same: "showing humiliation": al-dull wa-al-ṣagiar (Levy-Rubin 2016: 166).

In turn, Caliph Yazīd II b. 'Abd al-Malik (720-724) favoured the "Jacobites," especially the "monophysical" Patriarch Elias I of Antioch (709-722), who paradoxically was born to a Chalcedonian family, but joined the non-Chalcedonian christology upon lecture the works of Severus the Great of Antioch (512-538). Theophanes, on the other hand, blamed the Jews for the rise of iconoclasm. According to this chronicler, a Jew from Laodicea was to prophesy Yazīd II that he would reign for 40 years if he destroyed the crosses and cast out the images from the churches (Theophanes 1885: 260). Yazid II was to implement the iconoclastic edict that strengthened the confessional denominational divisions (Muqqaffa' 1910: 3: 72-73; Michael le Syrien 1901: 2: 489). At that time, additional taxes were also imposed on monasteries and churches of all Christian denominations (Lammens 1921b, 115).

Opposite pole: the Caliph al-Hišām's openness to Christians

Paradoxes of Muslim-Melkite coexistence
The successor of the relentless Yazīd II, Caliph al-Hišām (724-743) repealed some discriminatory laws. Moreover, in the quiet of his palace he reportedly liked to listen to prayers and Christian readings (Abu Assab 2014: 28-30; Tritton 1930: 106). He was even rumoured to say to the "Jacobite" patriarch of Antioch, Athanasius III (724-740), that when Christians began night prayers, he experienced such peace that he forgot all the troubles of governing (Muqqaffa' 1910a: 3: 75).

The spirit of tolerance during the reign of Hišām b. 'Abd al-Malik can be illustrated by the example of Hālid b. 'Abdallāh al-Qasrī (the governor of Iraq 724-738, died 743/4) widely called Ibn alNașraniyyah - "the son of the Christian woman." The mother to this Umayyad governor of Mecca and Iraq was a Christian. AlQasrī built a church for her directly behind the mosque in Kufa. When the ablution fountain was made, it was blessed by a Christian priest by the will of the governor. Al-Qasrī was said to be motivated by the fact that the priest's prayer would be heard more than that of a Muslim. Then he reportedly said that the Christian religion had great value. He also favoured many Christians in the administration of the caliphate (Gabrieli 1935, 16; the author uses the information from the work of Abū l-Farağ 'Abd ar-Raḥmān b. 'Alī b. al-Ğawzī [1114-1116]).

In the religious interactions of the Umayyad era, it happened that both Christians and Muslims followed the cross at funerals (Lammens 1930: 336-337). Interestingly, until the 2nd century of the Hijra, Christian writers insisted on making the sign of the cross in dorso on official documents, as evidenced by bilingual documents from Egypt. Sometimes Muslim administrators stamped their seals next to the Christian holy sign (Lammens 1930: 366-367). Muslim 
authority more than once resolved disputes between Christian churches, which took place, for example, in the 8th century in Aleppo, where the governor had to intervene in a dispute between Melkites and Maronites (Michael le Syrien 1901: 2: 460).

In the hands of the Christians was trade, various branches of crafts, and the "liberal professions." It was not infrequent that they ran schools attended by Muslim children. Architects, engineers, and people of science and art came from the Christian community. However, initially, military service was forbidden to non-Arab Christians. With time, after the conquest of Spain and Anatolia, Christians were also employed in the Muslim army, and held various functions (Lammens 1921a: 117).

\subsubsection{Negotiation of theories with practice: theological and legal conditions of Melkite existence}

Although Islam and Christianity are both monotheistic religions, they offer different images of God. It is commonly known that the foundation of Christianity awakens opposition to Islam: the deity of Christ and the Trinitarian nature of God. However, neither Muslims nor Christians viewed each other solely through the prism of religious differences. Of course, the foundation of mediaeval societies was religion, but religious diversity was also confronted with the necessity to live in one country, with similarities and conflicts of interests and with sociological conditions. All this meant that the status of Christians in the Islamic world varied greatly depending on the era and region.

Generally speaking, the Qur'ān renders an ambivalent judgment about Christians and their religion. This can be seen by juxtaposing negative and positive statements about the followers of Christ.

Ambivalent judgments about Christians in the Qur'ān Positive examples include an excerpt from surah 5.82: "And you will find that the nearest in affection towards the believers are those who say, 'We are Christians.' That is because among them are priests and monks, and they are not arrogant." Alongside this kind of opinion, however, the Qur'ān also presents negative opinions about Christians: "O you who believe! Do not take the Jews and the Christians as allies; some of them are allies of one another. Whoever of you allies himself with them is one of them. God does not guide the wrongdoing people" (5.51). The holy book of Islam holds a negative opinion about the Christian clergy, simply saying, "O you who believe! Many of the rabbis and priests consume people's wealth illicitly, and hinder from God's path. Those who hoard gold and silver, and do not spend them in God's cause, inform them of a painful punishment" (9.34). There are other statements in the Qur'ān that are unfavourable towards Christianity. Christians are 
Muslim mediaeval tolerance of Christians-not the modern type

Tolerance for Christians and the caliph's fiscalism accused of falsifying the doctrine of God; the doctrine of the deity of Jesus Christ and the Holy Trinity is a great deception $(18,5)$, preached by unbelievers and idolaters $(5,17 ; 5,23 ; 9,30-31)$.

It was to the Christians as Ahl al-Kitäb ("People of the Book") that Muhammad addressed the proposal, "O People of the Book, come to terms common between us and you: that we worship none but God, and that we associate nothing with Him, and that none of us takes others as lords besides God" $(3,64)$. Christians did not endorse Muhammad's belief that Christianity, Judaism, and nascent Islam are essentially identical. Hence in the teachings of the Prophet there is an accusation against Christians that they departed from the true monotheistic meaning of the Gospel (Kościelniak 2000a: 140).

Although Christians enjoyed the tolerance of Muhammad and the Muslims, it meant a completely different reality than the modern concept of tolerance. Today it could be defined as "the relative tolerance" of Christians. It was based partially on the Qur'ān, which, though inconsistent in its statements, contains the phrase of Muhammad: "There is no compulsion in religion!" $(2,256)$. On the basis of this statement, Christians sought tolerance from Muslim rulers.

To this day, there has been a lively discussion on a very con-

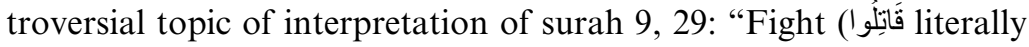
'kill') those who do not believe in God, nor in the Last Day, nor forbid what God and His Messenger have forbidden, nor abide by the religion of truth-from among those who received the Scripture - until they pay the due tax (الْجْزَيَّة, or a per capita yearly

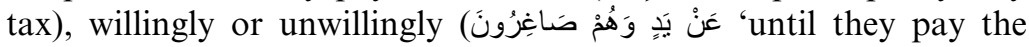
tribute with their own hand and are humiliated')." According to Józef Bielawski (1910-1997), the position of Islam is radical here, so this text contradicts and in fact abolishes all previous Qur'ānic dispositions which recommend a wait-and-see attitude towards polytheists and are tolerant towards the "People of the Book." In fact, the quoted passage makes no distinction between polytheists and nonMuslim monotheists until they are humiliated by tribute (Koran Bielawski 1986: 877).

Collecting large sums of money from Christians often meant that the Muslim rulers of Egypt were not interested in reducing their incomes by converting Christians to Islam. It is possible that the vision of fewer taxpayers encouraged a certain "tolerance" on the part of Muslims. Due to its ambiguity, the Qur'ân left great discretion in the treatment of conquered nations and Christians. Depending on the needs, Muslim rulers could refer either to the passages about tolerance of the "People of the Book" or to the idea of a war with pagans or hostility towards Christians.

In the first two centuries of the Hijra, Muslims systematically clarified the theory of Islam's superiority, thus claiming the right to 
exercise power over non-Muslims. "People of the Book," that is, addition to the problems discussed above Christians, Jews, and Zoroastrians, were referred to as "protégés" (ahl dhimmi). In return for paying special taxes on a regular basis and accepting fewer rights than those enjoyed by Muslims, "People of the Book" were guaranteed protection of life and property and the possibility of professing their religion (Le livre de l'impôt foncier, Abou Yousof Ya'koub 1921: 106-109). This is no place to outline the evolution of the status of "the people of the dhimma") and the problems arising from this practice (for more see Ferré 1988: 72-96; 1996: 82-83; Schacht 1952: 26; Tritton 1930: 5-17; Gardet 1962: 344-346; Abel 1970: 5-19; Abel 1945: 1-17; Fattal 1958: 18-20).

Without going into historical complexities, it is worth adding that the term dhimmi ("protected"), in relation to Christians, has not been precisely defined in Muslim legal treaties. Consequently, the Melkites experienced variety in the enforcement of the Umar Pact's requirements under different historical and geographical conditions.

The Qur'ān, as mentioned earlier, being inconsistent in its statements, could not exactly serve as the basis of agreements with the "People of the Book." Anyway, during the lifetime of Muhammad, the need to regulate the status of non-Muslims was not felt as much as it was during that of the Prophet's successors. Accurate theories about "protected people" were, therefore, developed much later, in situations that Muhammad could not have foreseen.

Muslim lawyers treated the agreements between the Muslim conquerors and the defeated Christian population as a kind of attachment to the jihad. This fact confirmed the close connection between the "holy war" with non-Muslims and the security of those among them who agreed to the terms of the dhimmi. According to Muslim lawyers, this "protection" made it possible for the defeated to see what a great honour it is to live in Muslim lands and what great benefits it brings to adopt Islam. Finally, it must not be forgotten that the finances of the Muslim state in the first centuries of Islam were essentially based on tax revenues levied on the Christians (and largely on the Melkites). Therefore, attempts were made to sanction this situation with a religious pretext as well (Morabia 1993: 265-479).

The policy towards non-Muslims developed in the 8th century was based on the decisions of 'Umar II, who gradually began to build an ideology of exaltation of Islam rather than of the superiority of the Arab conquerors. Moreover, over time, as Islamization progressed and taxes also had to be levied on an increasing proportion of the Muslim population, the concept of giyār ["differentiation"] became a

Melkites and the Pact of 'Umar: the stability of general principles and the variability of practical solutions 
Arab Christians as a subject of controversy

hallmark of non-Muslims in Islamic society for the centuries to follow (Levy-Rubin 2016: 168).

The Arabs who did not believe in the mission of Muhammad were an exceptionally difficult problem for the Islamic umma. Arab Christians belonged to three main denominations: "Nestorian," "monophysical," and Melkite. Although Muslim theologians and lawyers never defined Islam as an ethnic community, they nevertheless believed that Arabs should be Muslims. Muslim tradition confirms that Arabs, especially those living in the Arabian Peninsula who did not convert to Islam, suffered persecution under various historical circumstances (Tritton 1930: 90-92; Grunebaum 1962: 198) and that they were expelled from their homeland by Caliph 'Umar I (Mālik 1951: vol. 2: 892-893; Ibn Hišām, Saqqa, Abyārī, Šalabī 1955: vol. 2 : 356-358; Wensinck 1992: vol. 1: 361). Among the many hadiths on this subject, it is worth quoting the tradition from the collection of alMuslim (814-874) Ğihād, 63: "I will expel the Jews and the Christians from the Arabian Peninsula and will not leave any but Muslims."

Recently, there has been much debate about the authenticity of the tradition which ascribes to Muhammad the words about the need to expel the "People of the Book" from Arabia. The thesis of Henri Lammens (1862-1937) is debatable, namely whether the Jews of Wādī l-Qurā and the Christians of Nağrān, who were to be deported from Arabia to Syria and Mesopotamia, were to fall victim to the second caliph's extensive "nationalist" programme (Lammens 1921a: 362). It is known that this "programme" was not fully realized in the 1st century of the Hijra.

Thus, initially the principle of "protection" (dhimma) was more preferably applied to all but not Arabs, as the social/legal situation of any Arab should not be inferior to that of his Muslim Arab brothers (Tritton 1930: 89). With time, however, this belief lost its validity as the Christians of the Levant, including the Melkites, were Arabized. Nevertheless, according to lawyers, Arab apostates (who converted from Islam to, e.g. Christianity) had a choice only between Islam and the death penalty. The pragmatics of appreciation of the Arabic element was justified by the argument that God chose the Arabic language and with its help gave His revelation to mankind. Then it was concluded that an Arab could not be allowed to not see and respect supernatural qualities in this revelation (Abū Yūsuf Ya'qūb 1932: 131-133; Al-Māwardī 1909: 301; Fattal 1958: 74).

The Pact of 'Umar

For two centuries, the Pact of 'Umar has been the subject of intense research by Western scholars. This is not the place to summarize many of the findings. What is worth outlining here is the genesis and scope of this document according to the Muslim tradition. For many, even modern Muslims, the Pact of 'Umar was simply an answer to the question of Syrian Christians about their status in 
the Muslim state. The matter is completely different in the study of Western Orientalists. Determining the exact origins of the pact is extremely difficult, and perhaps those who say that it is impossible are right. This pact is rather the end product of the evolution of conditions to which "protégé" Christians had to submit. From all the surviving versions of this text, it is possible to extract the basic legal norms presented below, which were binding for all Christians.

A list of prohibitions and obligations for Christians from the Pact of 'Umar:

1. Obligation to host any traveling Muslim who asks for hospitality for up to three days.

2. Prohibition against using knockers (equivalent to bells) and saying prayers out loud.

3. Prohibition against building new churches.

4. Prohibition against publicly professing one's faith (processions, meetings, or prayers).

5. Prohibition against converting Muslims to Christianity.

6. Prohibition against studying the Qur'ān.

7. Prohibition against preventing people from converting to Islam and criticizing Islam.

8. Prohibition against wearing clothes like Muslims.

9. Prohibition against riding on a mount.

10. Obligation to wear the distinguishing sign.

11. Prohibition against using the saddle.

12. Obligation to respect and give way to Muslims.

13. Prohibition against building houses higher than Muslims.

14. Prohibition against carrying weapons.

15. Prohibition against having Muslim slaves.

16. Prohibition against owning slaves who previously belonged to Muslims.

17. Obligation to pay special taxes without any objection and to accept other humiliation from Muslims (Abū Yūsuf Ya'qūb 1932, 214; Tritton 1930: 63; Dennett 1950: 63; Fattal 1958: 60-69; Noth 1973: 282-314; Morabia 1993: 269).

There is no doubt that the conditions set out in the Pact of 'Umar do not correspond to the realities of the first half of the 7th century. Certainly the 7th-century Melkites could not be subject to all the restrictions mentioned in this document. Assigning many decrees restricting Christians to 'Umar I b. al-Hatțāb (634-644) was intended to lend credence to this practice as a tradition of managing the Muslim state, dating back to the times of the second caliph. Most likely, many of the restrictions listed in the Pact of 'Umar were applied during the times of the Umayyad Caliph 'Umar b. 'Abd 
al- 'Azīz (717-720), but the document as a whole was written several decades later. This is evidenced by the fact that the Christian obligation to wear distinctive signs was first introduced in the middle of the 8th century. On the other hand, since the oldest testimonies known to us, for example, from Abū Yūsuf Ya'qūb b. Ibrāhīm b. Habīb al-Kūfí (c. 729-798) attribute the authorship of the abovementioned restrictions to the Caliph 'Umar b. al-Hatțāb, this proves that the restrictions mentioned in the Pact of 'Umar were used at the end of the 8th century.

The Pact of 'Umar was finally issued at the beginning of the 9th century. Undoubtedly, it is a description of the actual state of Muslim-Christian relations around AD 800. Basically, in the form outlined above, it talked about the Melkites from the 9th century on. This apocryphal work was widely adopted by the Sunni Muslim world in the Middle Ages, when its authority was not questioned. Many Muslim authors believed that the failure to comply with those obligations, or a violation of even one of them, would automatically brand a Christian as a rebel who had broken the contract and was liable to the death penalty (Morabia 1993: 269; Fattal 1958: 60, 68; Tritton 1930: 12; Grunebaum 1962: 197).

The great tax paradox

Fiscalism as a source of Islamization

\subsubsection{Fiscalism as the engine of Islamizing Christians?}

It happened that the harsh treatment of Christians by governors of the Muslim state caused the displeasure of the caliph himself. The administrators, wanting to extract as much money as possible from the "protected" Christians, prevented them converting to Islam. A strange situation ensued. On the one hand, the "People of the Book" bent under the weight of the fiscal oppression of the Muslim state sometimes wanted to improve their fate by converting to Islam. The provincial administrators, however, were not interested in reducing their income by reducing the number of Christian taxpayers. In this way, paradoxically, it came to the point that some greedy Muslim governors inhibited the process of Islamization for financial reasons. Al-Tabarī noted that the caliph himself concerned about this awkward situation. 'Umar II was supposed to write to his governor in Egypt to report that "Muhammad was sent as a prophet, not a taxcollector or circumciser" (Crone, Hinds 2003: 79; Anjum 2012: 69).

The decreasing number of Christians meant that a smaller and smaller group had to bear the tax burden. For this reason, at the end of the 8th century, the Islamization of Christians as an economic and social process grew stronger (Ducellier 1996: 183-193; Le Coz 1995: 212-214). From time to time, Christian dissatisfaction found an outlet in rebellion. For example, in Egypt alone in the 8th century, there were six uprisings against the Muslim governments: three 
rebellions against the Umayyad administrators in 725, 739, and 750, and three during the reign of Abbāsid prefects in 752, 767, and 773 (Kościelniak 2002a: 203; Tritton 1930: 144; Dennett 1950: 87).

Mass conversions reduced the state's income. In this situation, Muslim lawyers were forced to develop new legal solutions for tax collection (Dennett 1950: 47-48; Morabia 1993: 488). Namely, a distinction was made between the lands conquered by force ('ard 'anwa) and territories that had capitulated ('ard sulh). Haraj was imposed on the first type, while the second group enjoyed considerable tax breaks. In practice, it meant nothing more than also collecting taxes from Christians converted to Islam (Abū Yūsuf Ya 'qūb 1932: 90-94; Māwardī 1909: 312). The new rules not only complicated the tax system and introduced new social distinctions, but also sparked numerous rebellions (Dennett 1950: 4, 38).

The situation of individual provinces of the caliphate was peculiar. Over time, the tax collection was adapted with varying intensity, somewhat differently in Syria, Egypt, or Lower Mesopotamia. This is evidenced, for example, by the legal treaties of Abū 'Ubayd al-Qāsim b. Sallām (c. 770-838) or Abū Yūsuf Ya qūb b. Ibrāhīm b. Ḥabīb al-Kūfì (c. 729-798) and Yahyā b. Âdam (died 818). Paying the land tax was the responsibility of every Christian owner, regardless of age, condition, or gender (Ibn Sallām 1935: 182, 277-279, 364, 379; Abū Yūsuf Ya qūb 1932: 61-65). The rates were often exorbitant. Basically, they depended on the will of individual administrators. This fiscal practice meant that the peasants sought protection from the richer. Thus, fiefs began to form (Cahen 1953: 25-52).

\subsubsection{Restrictions on the functioning of Melkites in the public space}

While Muslims guaranteed the existence and functioning of churches, they strongly opposed the building of new ones (Ibn Sallām 1935: 269; Abū Yūsuf Ya qūb 1932: 195). However, this law was not strictly

applied. Admittedly, this was very rare, but sometimes places of Christian cult were created in new cities. But in times of crises and economic and religious difficulties, there were plenty of opportunities for the profanation of churches. More than once, Muslims vented their anger by destroying or burning churches (Ferré 1988: 98-100; Morabia 1993: 280; Kościelniak 2002a, 196, 204, 206).

Muslims realized the power of Christian symbols. The Islamic tradition speaks of Muhammad, who had an aversion to the holy symbol of Christians. After the conquests, the manifestation of the cross was systematically limited. It was forbidden to exhibit it in places frequented by both Christians and Muslims. Such prohibitions

Prohibition on erecting new churches and Christian symbols 


\section{4}

The situation of the Melkite Church

were derived from the alleged utterance of Caliph 'Umar I (Ferré 1988: 100-101).

For example, Ibn Ḥabīb al-Kūfĩ lists Muslim ordinances on restrictions on the demonstration of Christian symbols. Crosses were allowed to be displayed outside the city without the use of flags and banners for one day of the year. The showing of the cross was forbidden inside the city, surrounded by Muslims and among mosques (Abū Yūsuf Ya qū in the East (equivalent to bells) - was basically subject to the same rigour as showing the cross (Ferré 1988: 101-102).

Obligation to wear distinguishing signs and other prohibitions

Prohibition of criticizing Islam and promoting anything against the religion
Muslim lawyers demanded other forms of stigmatizing "protégés." Christians were forbidden to carry weapons or ride a horse or any other animal that was considered noble. As early as the 8th century, special badges or clothing were introduced for Christians. Detailed legal provisions on this subject, however, only appeared during the reign of al-Mutawakkil (847-861). Most often, Christians differed in the colour of the fabric of their garment or turban. Typically, yellow was reserved for Jews, red for Sabeans and Samaritans, and blue for Christians (Tabarī 1991b). Another sign of belonging to a nonMuslim community was zunnār, a type of a cloth belt (Fattal 1958: 102) or a medallion seal worn around the neck in Upper Mesopotamia and Egypt. In particularly difficult times, when the "protégés" often escaped to avoid the fiscal oppression of the Muslim state, Christians were also stigmatized on their forehead, back, and hands (Ferré 1988: 89-91; Kościelniak 2002a: 203). It must be emphasized, however, that these practices were applied in a variety of ways depending on the region of the Muslim world and the historical circumstances (Morabia 1993: 280).

Severe punishments were also provided for those Christians who criticized Islam, the teachings of the Qur'ān or Muhammad. Spreading Christianity and inciting Muslims to apostasy, marriage between a Christian and a Muslim, spying on or helping traitors, criticism of the the Muslim community (Umma), and refusing to pay taxes were absolutely prohibited, usually under penalty of death (Abū Yūsuf Ya 'qūb 1932: 275, 294; Šāfi 'ì 1961: 4: 206, 250).

The status of Christians varied after the Muslim conquests, despite the Muslim guarantees. Periods of relative tolerance were replaced with times of trouble and vice versa. However, inconsistently, Christians were always charged with fees for the "protection" of the Muslim state. Certain professions that Islam prohibits Muslims from holding (banking or jewellery making) were allowed to be performed by Christians, as were breeding pigs or producing wine. Especially the latter two practicies had to be done 
in an almost hidden, or at least unobtrusive, way (Le Coz 1995: 200-205; Tritton 1930: 13).

When a "protégé" Christian fled to non-Islamic territories (dār alharb), he was treated as an apostate Muslim, except that if he was arrested, he could be made a slave. Severe penalties were meted out for failing to comply with even one of the provisions in the Pact of 'Umar. Some lawyers argued that such a Christian then only has a choice between accepting Islam and being killed.

It is true that all this burden of strict law was the fruit of the individual interpretations of Islamic theologians. However, they could always rely on the example of Muhammad, who dealt severely with those who opposed him or who did not agree with his ideas (Morabia 1993: 81).

\subsection{The condition of the Melkite communities and institutions}

It has already been mentioned that the Arab conquest of Syria and Egypt caused the separation of three Melkite patriarchates, Antioch, Jerusalem, and Alexandria, from the Byzantine Empire. The Arab-Byzantine wars coincided with the period of weakening of Constantinople by religious and political disputes. Divided Christianity in the territories occupied by Muslims almost everywhere had a double, and sometimes even triple, church hierarchy. The "Monophysites" had the opportunity to "react" to their antiByzantine sentiments. Michael the Syrian wrote with satisfaction that the memory of Chalcedon was erased from the Euphrates to the East (Michael le Syrien 1901: 2: 379).

\subsubsection{The patriarchate of Antioch}

The patriarchate of Antioch at the beginning of the 6th century, despite gaining autonomy by the Churches of Persia, Cyprus, and Jerusalem, still boasted a large number of bishoprics that could be recreated on the basis of Notitia Antiochena, dating from the first period of the reign of Patriarch Anastasius I of Antioch, that is, the years 561-571 70 and later 593-599. Robert Georges Joseph Devreesse (1894-1978), a scriptor in the Vatican Library, considered this document a forgery (Devreesse 1945), but Ernest Honigmann (1892-1954) strongly criticized this thesis (Honigmann 1947: 135-161). It follows from this document that this patriarchy was extremely resourceful in the bishoprics, as it consisted of 12 metropolises with suffragans, 5 metropolises without suffragans, 7 archbishoprics and 2 bishoprics with a privilege of exemption, and, most importantly, with 132 bishoprics.

Ecclesial organization of the patriarchate 
Table 3.1 Structure of the patriarchate of Antioch

\begin{tabular}{llr}
\hline Byzantine Province & Metropolitan bishopric & Number of dioceses \\
\hline Syria Prima & Antioch & 7 \\
Phenicia Prima & Tyr & 13 \\
Cylicia Prima & Tars & 7 \\
Osroene & Edessa & 11 \\
Syria Secunda & Apamea & 7 \\
Euphratesia Prima & Hieropolis & 9 \\
Arabia & Bosra & 19 \\
Cylicia Secunda & Anazarbos & 8 \\
Izauria & Seleucia & 24 \\
Phenicia Secunda & Damascus & 11 \\
Mesopotamia Prima & Amida & 8 \\
Euphratesia Secunda & Sergiopolis & 5 \\
Mesopotamia Secunda & Anastasiopolis & 3 \\
\hline
\end{tabular}

Thus, the patriarchate of Antioch included 158 bishoprics in total. There is no doubt that at the beginning of the 7th century, and especially later, after the Muslim conquest of Syria, this statistic was no longer valid, because the "Jacobite" hierarchy was developing parallel. In former Byzantine provinces, such as Osroene, Euphratesia Prima and Secunda, and Mesopotamia Prima and Secunda, "Monophysites" constituted the overwhelming majority, while Melkites were a minority. In turn, in provinces such as Cilicia Prima and Secunda, Syria Prima and Phenicia Secunda, there were both Melkites (approx. 50\%) and "Jacobites" (approx. 50\%). Finally, in the provinces of Cilicia Prima, Syria Secunda, Phenicia Prima, and Arabia, Melkites definitely prevailed over "Jacobites." When we exclude the bishoprics of Isauria and parts of Cilicia II, which were located on the Byzantine side after the Muslim conquests, we can estimate the number of Melkite bishoprics of the Antiochian patriarchate at about 60. Moreover, in the mid-8th century, part of the patriarchate of Antioch which remained in the Byzantine Empire was attached to the patriarchate of Constantinople by order of the emperor (24 bishoprics). These territories returned to the jurisdiction of Antioch after the Byzantines recaptured the city in 969. Incidentally, it is worth adding that Georgia also broke away from the Antiochian patriarchate. Its catholicos consecrated by the Patriarch of Antioch paid a fee for this until the 10th century, when the Melkite Patriarch John III (997-1021) renounced this contribution to the Melkite patriarchate of Jerusalem (Troupeau 1999: 326-327).

List of Melkite patriarchs of Antioch, 634-750
Reconstructing the list of the patriarchs of Antioch with the exact dates of their ministry between 634 and 750 is extremely difficult, debatable, and, in some cases, very controversial. Historians often base their work on laconic references, and have problems dating the years of the office of individual patriarchs. We have little 


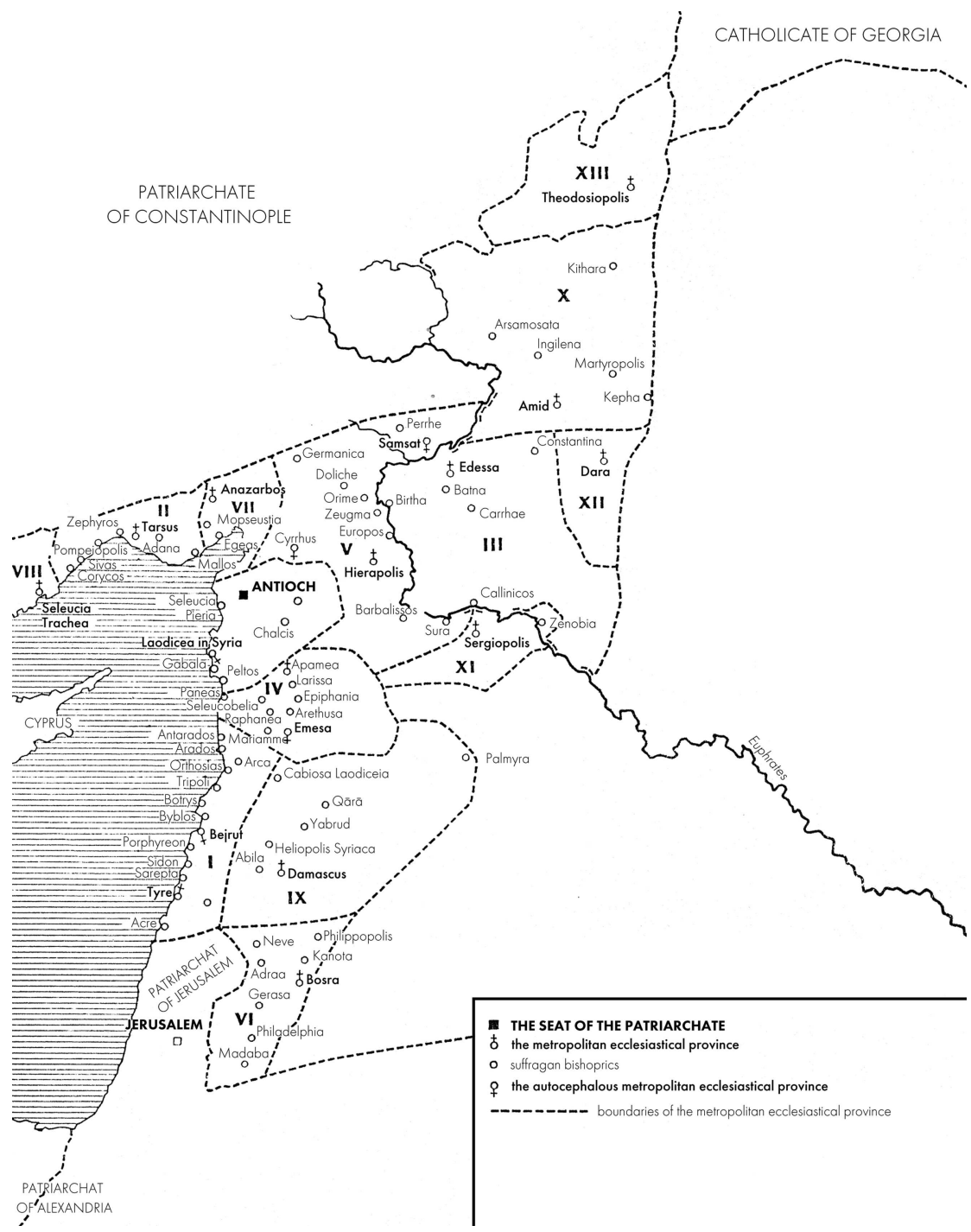

Map 3.1 The patriarchate of Antioch according to Notitia of Anastasius I.

information about most of the hierarchs of this period. There was also a long vacancy in the first half of the 8th century. For this reason, there are significant discrepancies among researchers. The list presented below can, therefore, be considered one of the possible suggestions. Thus, in this period, about eight or ten patriarchs could have sat on the patriarchal throne. The chronology of their ministry is as follows (Grumel 1958: 446-448; Karalevskij 1924: 697-700; Chaine 1925: 254-256): 
sede vacante

Macedonius

George I

Macarius

Theophanes

Thomas

George II

sede vacante

Stephen III or IV

Theophylact b. Qānbara
609-639

639/640-649 (?) 662(?)

(?)-(?) presumably 662-669

(?)-681 presumably 669-681

681-(?) presumably 681-684

(?)-685 (?) or Sebastian (687-690)

685 (?)-702 (?) presumably 691-702

702 (?)-742 (743?)

$742 / 743-744 / 745$ presumably $743-744$ 744-750
Monotheletism and other elements of the weakened position of the patriarchate

Patriarchs of Antioch residing in Constantinople
The Antiochian Melkites struggled not only with the "Monophysites" but also with the adherents of Monotheletism, which, as already mentioned, was the emperor's official attempt to reconcile two conflicting sides: the supporters of Chalcedonian Orthodoxy and the "Monophysites." This resulted in dangerous phrases about the one will of Christ, condemned both by Rome and by many Greek theologians. In the 7th century, representatives of both options were present on the Antiochian capital.

This apparently internal problem of the Christians resulted in various internal tensions that made the Melkite Church even weaker towards the new Muslim authorities (Hovorun 2008: 53-92). Moreover, the situation was complicated by the fact that the Antiochian patriarch was appointed by the emperor, which, with Antioch being part of the Arab Empire, created further problems.

When the patriarch of Melkite, Anastasius II (558-609), died in 609, the only resident patriarch in Antioch for many years was the "Jacobite" Patriarch Athanasius I (595-631). The Melkite patriarch's seat was vacant in the sense that the titular bishops of Antioch resided at the emperor's side in Constantinople. In 628[?], the first "Melkite Monotheletist" bishop Anastasius III (620-628[?]) was appointed to the seat of Antioch. During the Arab conquest of Syria, in August 635, the metropolitan of Melkite, whose name we unfortunately do not know, who had been residing there for six months, negotiated the terms of the Muslim takeover of Damascus (Karalevskij 1924, 592). After the Byzantines had left Antioch definitively, Emperor Heraclius appointed a new patriarch, Macedonius (639/640-649/662[?]). He was also a Monotheletist, like almost all bishops under his authority. Macedonius was condemned at the synod of Lateran (649). Two of his successors also professed Monotheletism: George I (7th century[?]-[?] presumably 662-669), who resided in Constantinople, and Macarius I ([?]-681 presumably 669-681). Nevertheless, Macarius I was accused of heresy and deposed from the episcopal see in AD 681 at the VI 
Ecumenical Council and replaced by Theophanes (681-[?] presumably 681-684), who signed the conciliar decrees (Eutychius 1909: 13, 127). The Council bluntly condemned the Melkite bishops favouring Monotheletism, saying that "the contriver of evil did not rest, finding an accomplice in the serpent and through him bringing upon human nature the poisoned dart of death, so too now he has found instruments suited to his own purpose-namely Theodore, who was bishop of Pharan, Sergius, Pyrrhus, ... Cyrus, who held the see of Alexandria and Macarius, who was recently bishop of Antioch, and his disciple Stephen - and has not been idle in raising through them obstacles of error against the full body of the church" (The Council of Constantinople 1990).

The next patriarchs Thomas ([?]-685[?] or perhaps Sebastian [687-690]) and George II (685[?]-702 presumably 691-702) were already firm supporters of the Chalcedonian doctrine (Synodus Constantinopolitana 1763: 345).

Rome tried to prevent the development of Monotheletism, as evidenced by the activities of Pope Martin I ([649-655], Epistolae et decreta 1763b: 827). The Bishop of Rome appointed two of his vicars for Antioch and Jerusalem. Of course, this mission was not an easy undertaking. Although they were unable to fulfil the task, it is seen by some modern authors as one of the earliest examples of Western Christianity's concern for the Christian communities under Muslim rule (Karalevskij 1924: 592; Richard 1990: 389).

After the death of George II in 702, the Antiochian patriarchal throne remained vacant for 40 years, that is until 742: the second year of the reign of Emperor Constantine V Kopronymos (741-775) Sede vacantein patriarchal throne of Antioch (Theophanes 1885: 270). In fact, the situation of the vacant capital of Antioch, claimed by the Byzantine emperor, had been connected with the Arab conquest of Syria. This condition was probably a consequence of the fears of the Caliph, 'Abd al-Malik b. Marwān (685-705), who looked unfavourably at the Melkites' close relations with Byzantium.

In addition, the rulers of Byzantium kept in Constantinople the titular patriarchs of Antioch. It seems that the metropolitan of Tyre had the powers of the Melkite patriarch of Antioch at that time. The matter was also complicated by the Arab-Byzantine wars of this period. In the second half of the 7 th century, Byzantium was only capable of pursuing a defensive policy. The Arabs not only attacked the imperial possessions in Asia, but also launched several naval attacks on Constantinople itself. The Byzantine emperor Leo III (717-741), the progenitor of the Syrian dynasty, recovered from this tragic situation. He finally repelled the Arab troops (Gibb 1958: 219-233; Lilie 1976). Understandably, in the atmosphere of these struggles, the Melkites, traditional supporters of the emperor, were

Rome and the Melkites 
One of the most painful Melkite losses: the confiscation of St John the Baptist basilica

\section{The situation of the Melkite Church}

marginalized, as were the Christians in Antioch who manifested their attachment to Byzantine theology after the Muslim conquests.

During this period, the Melkites suffered a great loss: the magnificent basilica in Damascus. In the Roman period, it was a temple dedicated to Jupiter. This monumental building was rebuilt into the basilica of St John the Baptist during the reign of Emperor Theodosius I (379-395). Mediaeval Melkite chroniclers praised its beauty and monumentality (Eutychius 1909: 42). However, in 705 Caliph al-Walīd I (705-715) recaptured the cathedral from the Melkites, turning it into a mosque.

One of the most important sources of the loss of this Melkite basilica of St John the Baptist is the tradition passed on by Ibn Asākir (Ibn Asākir 1959: 27-38). This author gives different versions of how Walīd I supposedly confiscated the Melkite Basilica and the

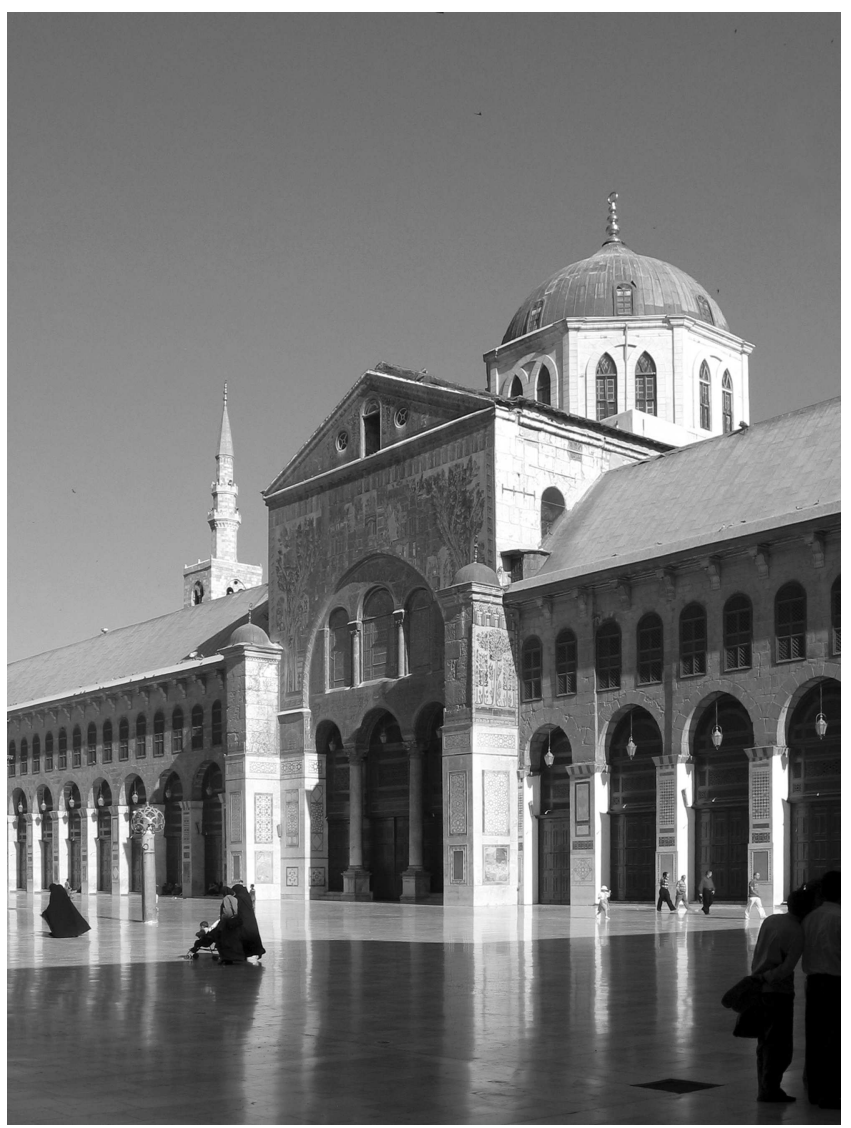

Figure 3.2 Umayyad Mosque in Damascus - the former Melkite cathedral of St John the Baptist (the author's private collection). 
Christian efforts to preserve it. One of them says that the Muslims did not have enough space to pray (Ibn Asākir 1959: 36, 60-61). However, many modern scholars consider the information of an alleged lack of space for prayer to be an insufficient explanation since the Muslims could have built a mosque elsewhere. It seems that the main reason for this action was to obscure Melkite Christian culture by a Muslim mosque (Nasrallah 1992: 139-144), as the Arab writer and geographer al-Muqaddasī (died 988) seems to attest (Al-Muqaddasi 1963: 173-174). There are some indications that the Melkites and the Muslims, for more than 70 years (from 635 to 706), shared the courtyard of the basilica of St John (Nasrallah 1992: 139-144; 1985: 1-2: 41-49; Dussaud 1955: 219-250; Sauvaget 1932: 13-15; Creswell 1958: 60-61). The Melkites and the Muslims worshipped there using the same temenos (Flood 2001: 2), but the mosque was next to the church. The mediaeval Arabic historians get their information from two different traditions. It is variously said that the church was appropriated either by force or by agreement. Some sources-for example, Bar Hebraeus-report that the Christians accepted the decision of Walīd I and took money or some new place as recompense. The attempt to verify the historicity of these explanations, even if dating from a hundred years ago, led to a critical conclusion. Some authors doubted that the Christians sold or changed the basilica. However, some traditions reported that Walid offered money to the Christians and that the information about the place in any other location of Damascus was added by later authors. If the Christians had agreed with the caliph's decision and had received compensation, they would not have had the right to complain to 'Umar II about the forced capture of St John church. The majority of authors, including Ibn Asākir, reported that the basilica had been taken without the Christians' consent. The poets in the Umayyad court, such as Hammām b. Ġālib al-Farazdaq (c. 640-c. 730), celebrated the seizure of this church in their poems (Ibn Asākir 1959: 42-43; Sauvaire 1894-1896: 192-193). In addition to these historic passages, some traditions say that Walìd I himself initiated the demolition by driving a golden spike into the church. A new mosque was built on the foundations of the St John basilica. (Creswell 1969, 151-96; Hillenbrand, Islamic Architecture, Edinburgh 1994: 68-72; Grabar 1973: 104-38; Finster 1970/1971: 83-141).

In the atmosphere of distrust of the Christians associated with Greek culture and tradition, the "Jacobites" gained a privileged position in Syria (Michael le Syrien 1901: 2: 480). Caliph Yazīd II

Tensions between Melkites and "Jacobites" (724-743) allowed the solemn ingress of the "monophysical" Patriarch Elias I of Antioch (709-722), which had not happened in Antioch since the Melkite Patriarch Severus the Great of Antioch (512-538), that is since the apogee of the Melkite-"Monophysite" 


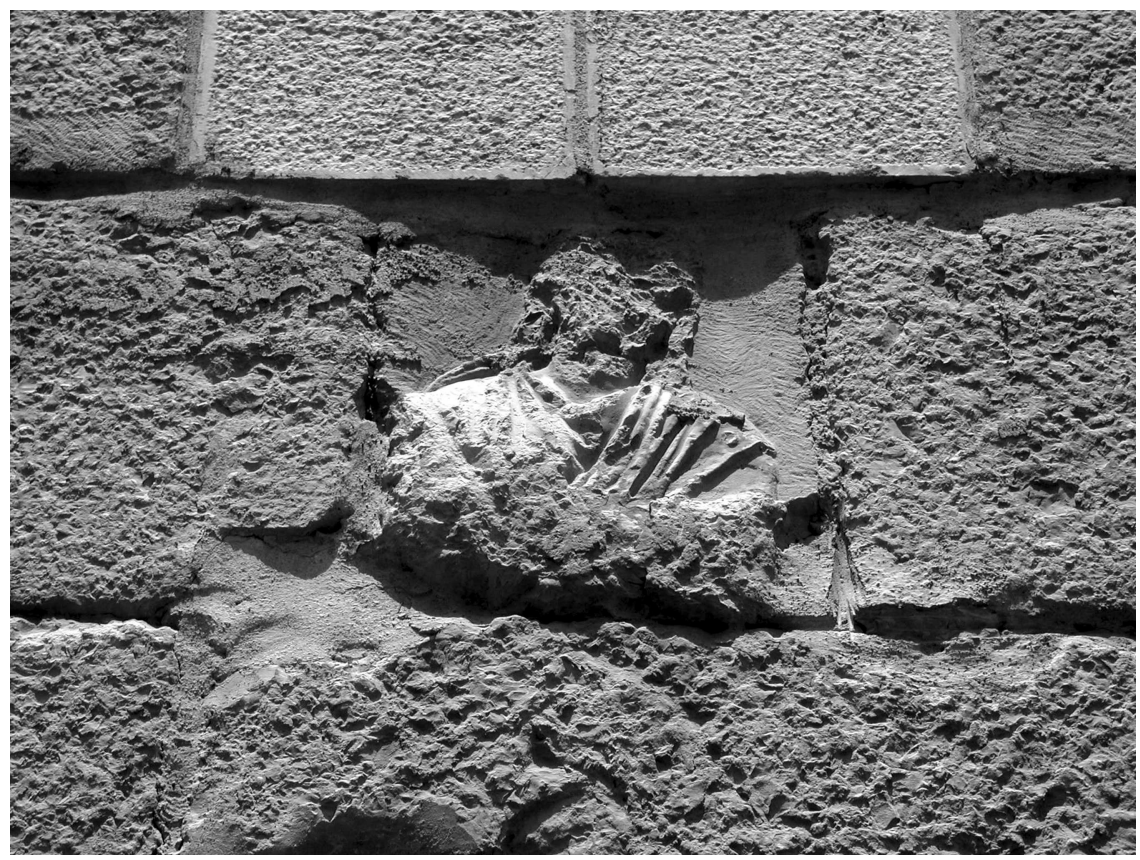

Figure 3.3 Fragment of the walls of the Umayyad mosque in Damascus, in which the local Christians recognize the damaged image of Jesus (the author's private collection).

controversies (Karalevskij 1924: 596). Despite great opposition from the Melkites, the "Jacobite" Patriarch Elias I of Antioch also built a great basilica in Antioch and a church in Sarmad (Michael le Syrien 1901: 2: 490-491; Bar-Hebraeus 1890: 298). The relationship between the Melkites and the Syrian and Egyptian "Monophysites" was difficult because the Arabs favoured the churches which were not linked with Byzantium. Muslim policy contributed to the deepening of differences between Christians (Nasrallah, Haddad 1996: 58-59).

The difficult situation of the Melkite hierarchy after $\mathbf{7 4 2}$
In 742, Caliph al-Hišām finally allowed the Melkite clergy to elect a patriarch on the condition that he would permanently reside in Antioch and have limited contact with the Byzantine emperor (Eutychius 1909: 46; Karalevskij 1924: 597; Nasrallah, Haddad 1996: 54). The Syrian monk, Stephen III (742/743-744/ 745 ), was then elected, but was quickly punished. The caliph ordered that he should have his tongue cut out for making incompetent statements. According to Theophanes (died 817), the patriarch of Melkite Stephen III sat in the Antiochian see for two years between 742 and 744. Peter, the metropolitan Melkite bishop of Damascus, also became a martyr for his polemics with Islam 
(Theophanes 1885: 270-271). These years, however, were a time of great dogmatic controversy, not only between Christians but also in Muslim-Christian polemics. The Melkites in this intellectual struggle were John of Damascus (died 749) and Theodore Abū Qurra (c. 740-820; I write about his activities in the next chapter).

After the death of Patriarch Stephen III, in the fourth year of the reign of Constantine V Kopronymos (741-775), Caliph Marwān II (744-750) recognized the election of the patriarch of the Melkite priest of Edessa, Theophylact b. Qānbarai (744-750), who we know was persecuted by Maronites (Michael le Syrien 1901: 2: 511; Theophanes 1885: 275). This patriarch assured Pope St Paul I (757-767) about good relations with Rome in a letter that unfortunately has not survived till today. We learn about its existence from a mention in the letter of Pope Hadrian I (772-795), addressed to Charlemagne (748-814), which is one of the few references to the patriarchs of Antioch of this era (Synodus Niceana 1767: 764). The historian Eutychius, the Melkite patriarch of Alexandria (933-940), stated that Theophylact ruled the Church of Antioch for 23 years (Eutychius 1909: 49), that is, until 767 or 768, but this does not seem convincing.

In addition to the problems discussed above, the patriarchy of Antioch was also shaken by the iconoclastic dispute. Iconoclasm divided the Byzantine Church (726-843) into two fiercely opposing parties for over a century, leading to a wave of rape and persecution on both sides. There was such a sharp division in society that this crisis became one of the most important turning points in the history of the Melkite Church. There is no room here to cover all aspects of this complex dispute. Nevertheless, the extent of the problem is evidenced by various contemporary Byzantine documents (Les Regestes 1936: 1-254). Many studies show the vitality of the cult of icons among Christians of various denominations in the Middle East, based on many sources from the periods of iconoclastic disputes (Teule 2007: 324-346; Griffith 2007: 347-380).

It is worth remembering that the classic explanation of the origins of iconoclasm refers precisely to the Melkite milieu in Syria, from where the Umayyads ruled the caliphate. Greek, Syrian, Arab, and Armenian sources refer to the alleged decision of Caliph Yazīd b. 'Abd al-Malik (c. 690/91-724), who was to be persuaded by a Jewish magician to issue a decree prohibiting the placing of images in churches and public places in the caliphate. In return, the mage would promise the caliph a long reign, though in fact Yazid II died shortly after the edict was issued. Nevertheless, the prohibition issued by the caliph on images was to provide Leo III, susceptible to the influence of "Saracens," a pattern for iconoclasm (Vasiliev 1956: 25-47). 
This extremely popular version of the genesis of iconoclasm (especially that it was significantly recorded at the Second Council of Nicaea in 787) was considered authentic for centuries. Some modern scholars have even given an approximate date for this edict of Yazīd II, that is, 721 (Crone 1980: 59-95; Griffith 1992: 121-38; 2007: 347-380; Gouillard 1968: 243-307; Anastos 1968: 5-41; Stein 1980; Grabar 1976: 112-162). However, the classical version has been recently criticized by some authors and denounced as a forgery. This story not only has a mythological element, but also seems to be eminently apologetic and polemical in nature by linking destructive iconoclasm to the Empire's archetypal enemies, the Arabs. Thus, instead of looking for internal causes, like the cause of the crisis, the lack of sources of iconoclasts prevents us from throwing the proper light on the subsequent "propaganda" of the followers of icons (Gero 1973: 59-84; Speck 1990; Grabar, 1977: 45-52). In the early stage of iconoclasm (726-730), John of Damascus wrote the defence of the cult of images, but he did not mention the edict of Caliph Yazīd II or any other Arabic sources (Griffith 1992: 104; 2007: 347-380). It is possible that iconoclasm could have occasionally been practiced by some Muslim officials, as evidenced by the statement of one of the bishops at the Second Council of Nicaea: "I was a child in Syria when the Saracen leader was destroying the images" (Concilium Nicaenum II 1767b: 200). However, the unreal meetings of rulers with heresiarchs and sometimes their polemists, or impersonating the names of caliphs and emperors was quite a common theme in Eastern literature. It was, in a way, a kind of framework on which various topics were presented: those important for a given community and those controversial. One example is the apocryphal correspondence between the Caliph 'Umar II (717-720) and Leo III (Gaudeul 1995; 1984: 109-157; Sourdel 1966: 1-33; Jeffery 1944: 269-332; Kościelniak 2002b: 97-105). In my opinion, however, the Muslim idea of tawhìd, hostile to portraying of any Sacrum on icons, was present in the Syrian Melkite milieu and it might just have awakened an aniconism from the old Judeo-Christian tradition.

Anyway, the fact is that in 726, Emperor Leo III Isaurian (717-741) issued an edict condemning the cult of images, which resulted in the destruction of priceless works of art. Iconoclasm reached its zenith during the reign of Leo III's son, Constantine V Kopronymos (741-775). On the one hand, it was associated with a specific ideology, while on the other hand it seems that the Byzantine emperors who supported the iconoclasts wanted to abolish the diversity of religious practices in the multinational state (Stein 1980; Menges 1938; Grabar 1984; Alexander 1958; Bréhier 1904; Ostrogorsky 1939). 
Finally, Antioch spoke out against the iconoclastic orders of the Byzantine emperor. The most prominent representative of theology in the 8th century in the Levant, John of Damascus, became famous as the greatest defender of the cult of images, not only in the Melkite patriarchates, but also in the entire Christian world (Oratio pro sacris imanigibus, PG 94, 1231-1420). The Old Testament prohibition of making images (Ex 20: 4; Dt 5: 8) applied only to representations of God the Father. On the other hand, he approved of the iconography of Christ, the Blessed Virgin Mary, and the saints, explaining that he did not worship the images as such but only the persons depicted in them (Louth 2003; Olewinski 2004; Baladi 1951: 13-25).

Nevertheless, the Melkites' attitude towards paintings during this period was not always unequivocal or firm. Juan Signes Codoñer (1964-) has analysed the sources on the cult of icons among the Melkites between 726 and 843 . Contrary to the common, and essentially unquestionable, belief that the Melkite Church was an unequivocal supporter of images, the author made important distinctions (Codoñer 2013: 135-187). In terms of the beliefs of the faithful of the Melkite Church and the lower clergy, one can speak of unequivocal support for the cult of holy icons. On the other hand, the assertion that the entire Melkite hierarchy was for or against iconoclasm raises serious reservations.

The attitude of the weak patriarchs of Antioch was determined by the political/ideological struggle in Constantinople. It seems that the Melkite hierarchs probably did not want to get involved in polemics and conflict which were not their own local problem. For this reason, Constantinople repeatedly used its position to create an image of unanimous support for the politics of the Byzantine Empire among the Melkite patriarchates. Antioch's cautious involvement in this conflict is illustrated, for example, by the fact that one of the most eminent Melkite theologians of the time, Theodore Abū Qurra, simply ignored the very existence of the Second Council of Nicaea. Nevertheless, it seems that historians do not yet have evidence of a direct introduction to the practice of iconoclasm in Syria (Codoñer 2013: 186-187; Agachi 2016: 259-268).

\subsubsection{The patriarchate of Alexandria}

Unfortunately, due to the acute lack of sources, it is impossible to answer many questions on the condition of the Melkite Church of Alexandria at this time. However, it does seem that the history of the

The Melkite patriarchs of Alexandria, 634-750 Melkite patriarchate of Alexandria was more dramatic than that of Antioch. The aforementioned Cyrus, the Melkite patriarch (631-642) who negotiated the surrender of Alexandria with 'Amr b. al- 'Ạs alSahmī in November of 642, died a few months later. He was succeeded by a certain Monotheletist deacon, Peter, who is referred to in 
the literature as Peter III (or Peter IV? [643/644-651 or 642-651]). When the Byzantine army left Egypt in AD 645, the Melkite patriarchal basilica fell into the hands of the Copts and the patriarch took refuge in Constantinople, where he was nominally bishop of the capital of St Mark and from where he tried to run his community (Theophanes 1885: 270; Jean de Nikioû 1883: 572; Nicephorus 1865: 920; Butler 1978: 508-526; Grumel 1958: 443).

The list of the Melkite patriarchs of Alexandria between 634 and 750 is as follows (Grumel 1958: 442-444; Maséro 1923: 361-379; Patriarchate of Alexandria 2011):

The collapse of the organizational structure of the Melkite patriarchate of Alexandria

A new tide in the Melkite-Coptic confrontation?
630 or $631-632$

Cyrus

$643 / 644-651$ or $642-651$

Peter III=Peter IV [?]

sede vacante

651-727 (questionable pontificates in

Constantinople [?]: Theodore II; Peter IV=Peter

V; Peter V = Peter VI; Theophylact; Onopsus

Cosmas I

Thus, in the period of 641-750, the Melkite patriarchate of Alexandria had only three patriarchs that were relatively well attested by historical sources. Nevertheless, the influence of Cyrus' successors in Egypt was far more marginal.

At the beginning of the 7th century, the patriarchate of Alexandria had nine provinces and hundreds of bishoprics. Table 3.2 shows the organization of the Melkite Church of Alexandria just before the Arab conquest.

This relatively well-developed and prospering organization of the Melkite patriarchate of Alexandria was destroyed by several factors: the emergence of a parallel, competing "monophysical" hierarchy, the Arab conquest and, with it, the departure of the Byzantines. We do not have enough information on how many dioceses survived the

Table 3.2 Structure of the Melkite patriarchate of Alexandria

\begin{tabular}{llc}
\hline Byzantine province & Metropolitan bishopric & Number of dioceses \\
\hline Egypt I (Aegyptus Primus) & Alexandria & 14 \\
Egypt II (Aegyptus & Cabasa & 8 \\
$\quad$ Secundus) & & \\
Augustamnica Prima & Pelusium & 15 \\
Augustamnica Secunda & Leontopolis & 8 \\
Arcadia & Oksyrynchos & 9 \\
Tebaida Prima & Antinoe & 9 \\
Tebaida Secunda & Ptolemais Hermiu & 14 \\
Libia Prima & Ptolemais & 2 \\
Libia Secunda & Darnis & 8 \\
\hline
\end{tabular}


Arab conquest. It is only known that less than 200 years later there were only about six of them (Troupeau 1999: 340).

It would seem that the dramatic Melkite-"Monophysite" rivalry in the eastern Byzantine provinces led to the insurmountable dislike of both groups. There are many indications, however, that these two Christian denominations were not always radically separated regionally and dogmatically. On the other hand, they were not permanently united. It was a kind of peaceful coexistence resulting from the necessity to regulate the relations between two communities living in the same area. For example, during the reign of the Chalcedonian Patriarch John the Merciful of Alexandria (c. 606-c. 616), "Monophysites" and Melkites not only did not take hostile action against each other, but some Copts also participated in the Melkite liturgy (Papadopoulos 2009: 457-458; Christides 2016: 7). This was probably due to the conciliatory attitude of Heraclius who, as has already been mentioned, tried to ensure the unity of the Empire by promoting a theological compromise in the form of Monotheletism.

However, John, bishop of Nikiû, revealed the disastrous policy of the Melkite Patriarch Cyrus towards the "monophysical" Coptic community (Jean de Nikioû 1883). It has already been mentioned that after 645 the Melkites lost their cathedral and that their patriarch resided in Constantinople. This is one of the interactions in postByzantine Egypt, which was a reaction to Cyrus' policy. History of the Patriarchs of the Coptic Church of Alexandria describes the persecution of Coptic Patriarch Benjamin I of Alexandria (623-662). Forced to flee, Benjamin kept to various corners of Egypt, finally settling in the remote "Monophysite" monastery in Upper Egypt. Moreover, immediately before the Arab conquest in 641, the majority the Coptic "Monophysite" bishops were also replaced by Melkite bishops (Muqqaffa' 1907: 2: 492, 493, 498).

Some scholars have assumed that due to the close ties of the Melkites to the Byzantine Empire, Muslim Arabs generally treated the Copts much better than the Melkites (Papadopoulos 2009: 471; Müller 1959a: 376). However, Vassilios Christides claims that the fast reorganization of the Coptic Church after the Arab conquest and the systematic decline of the Melkite patriarchate of Alexandria were not caused by the Arabs' preferential treatment of the Copts (Christides 2017: 4-5). It seems that the separation of the Melkites from the political and financial backbone of Byzantine played a significant role, but we must absolutely also mention the charismatic role of Copt leader Patriarch Benjamin I of Alexandria (623-662) who returned to Alexandria around 645, after the Arab conquest. His vigorous actions greatly strengthened the position of the Coptic Church, which increasingly ignored the presence of the Melkites (Müller 1959b: 323-347).

Muslim preference for Copts over Melkites? 
In fact, Muslim authorities also accepted the autonomies in the Coptic and Melkite jurisprudence because, in the 7th century, the Arabs were not interested in the Melkite-Coptic theological dispute. They simply took as a starting point the existence of two Christian communities that were equally subject to Muslim law (and later to the limits of the Pact of 'Umar). Copts and Melkites were treated very differently, as can be seen in the case of relationships at the highest levels of government. For example, 'Amr b. al- 'Ạs al-Sahmī received the Coptic Patriarch Benjamin I of Alexandria, recognizing him as the head of the "Monophysical" community of Egypt (Muqqaffa' 1907: 2: 496), while on the other hand, the suggestions that the governor considered Benjamin to be the representative of the entire Christian Egyptian nation seem to be exaggerated (Müller 1991: 376). At the same time, the Arabs did not ignore the structures of the Melkite Church, although it is difficult to agree without reservation with the opinion (Papadopoulos 2009: 503) that Arabs recognized the leadership of Patriarch Peter III ([Peter IV?] 643/644-651 or 642-651), who had left Alexandria and spent the rest of his term in Constantinople.

Despite the specific modus vivendi of the two Christian communities

Loss of churches by Melkites

The vacant throne of the patriarch of Alexandria and Patriarch Cosmas I in Egypt, Cyrus' policy and the emperor's standard favouring of the Melkites brought disastrous long-term results. When the Greeks left Egypt, the Melkites were left at the mercy of the Muslim rulers. It seems that the Melkites, who were used to being supported by the Byzantine authorities, found it difficult to forge new relationships with the Copts, which they had to work out without imposing anything.

The Copts took over most of the Melkite Churches. Some researchers suppose, however, that several churches were simply abandoned by the Greeks leaving Egypt (Christides 2017: 5). In any case, this loss was acute and testified to the structural decadence of the Melkite patriarchate. At the beginning of the 8th century, the situation was very serious (e.g. in Alexandria, the Melkites had only one church left). The state of affairs changed in 742 when Patriarch Cosmas I (727 [731?] or 742-768) was appointed to the patriarchal throne after more than 90 years of vacancy. He negotiated with Caliph Hišām b. 'Abd alMalik the request for the return of several churches, including the Kaisarion church. The patriarch also tried to recover the church in Mariut from the "Monophysites," but these efforts failed. The caliph ordered the prefect of Egypt, "Abd al-Malik, to conduct an investigation. The governor, in the presence of the Melkite Patriarch Cosmas and "monophysical" Patriarch Michael I (743-767), settled the dispute in favour of the Copts (Troupeau 1999: 341).

Practically, for 76 years, from the Arab conquest until 727, the reign of Caliph al-Hišām, Alexandria was also a vacant patriarchal capital (Eutychius 1909: 46). This does not mean that the Egyptian Melkites, who prided themselves on their apostolic origin and great historical 
importance of Alexandria, were completely absent from the life of the universal Church. We know the names of some priests who represented the Melkite communities of Egypt in place of the patriarch (their names, moreover, were introduced into certain lists of the patriarchs of Alexandria): Theodore, known from the synod in 655 (Grumel 1958: 443); Peter IV, who signed the documents of the Sixth Ecumenical Council in 681 (Subscriptiones 1765: 688); Theophylact, who participated in the synod in 695; Onopsus, who was elected patriarch, and immediately converted to "Monophysitism" around 711; or the little-known Eusebius (Grumel 1958: 443).

It is worth paying more attention to the reactivation of the Melkite patriarch residing in Alexandria in 727. Like in many other cases in the history of the Melkite Church in this period, the very appearance of Cosmas, patriarch of Alexandria, is shrouded in mystery. Historians usually assume that Cosmas began his service in 727 (Papadopoulos 2009: 506), although some sources suggest 731 (Eutychius 1909: 45). It is interesting that Cosmas was also supposed to be illiterate, and was probably a "needle maker in the market place" before his election (Muqqaffa'1910: 3: 105). At the time, however, illiteracy was not an unusual thing. Many of the Levant hierarchs of that time were illiterate, and the scribedeacons were authorized to make copies on their behalf (Christides 2017: 8; Papadopoulos 2009: 343). As a "goldsmith," working for the governor, he was said to obtain Muslim support for his candidacy. It was the governor of Egypt who helped him ascend to the patriarch's throne.

Historians stress that he was probably the last Melkite patriarch in the Middle Ages to commit himself to the idea of uniting conflicting Christian communities. Cosmas' activity coincided with the rule of Coptic Patriarch Michael I (743-767). Cosmas had also been highly respected by the Copts (Muqqaffa' 1910: 3: 113; Christides 2017: 8; Labib 1991: 1411). We do not know exactly why the attempts to reconcile the Melkites with the Copts failed. Critical analysis of sources does not help to explain this phenomenon in terms of national or racial divisions (the very concept of the nation is modern). Also, no convincing arguments for any specific sociopolitical cause were found (Christides 2017: 10; Wipszycka 1992: 83-128).

Although Melkite intellectual circles suffered a serious crisis after the departure of the Greeks, the Melkite patriarchate of Alexandria continued its intellectual tradition for nearly a hundred years after Melkite intellectuals of Egypt the Arab conquest. Especially in the field of medicine, the work of John Philoponus (c.490-c.570) was continued (he was known among Arabs as Yahyā al-Naḥawī). The apostate 'Abd al-Malik b. Abğar al-Kinānī (at the turn of the 7 th and 8 th centuries), who converted to 


\section{0}

The situation of the Melkite Church

Islam from Christianity, was a continuator of Greek thought, and spread medical science in the Arab world (Klein-Franke 1982: 30; Leclerc 1876: 38, 56).

The process of Arabization

Without the shock of iconoclasm
Arabization affected the Melkites of all three patriarchates. It seems that it was more intensive in Egypt, because Melkites were in the minority there, and the Coptic culture was not an attractive alternative for them. The Caliph Abd al-Malik banned the use of Greek in official correspondence. Research indicates that the first Greek-Arabic bilingual documents date back to 643, and the last can be traced back to 719 . The last administrative papyrus written in Greek is dated 709 (Anawati 1990: 243).

In turn, in the patriarchate of Antioch, the oldest Christian bilingual document (Greek-Arabic), containing Psalm 78 from Qubbat al-Hazna (Dome of the Treasury, Damascus), suggests that the Eucharist in the Orthodox Antiochian rite in Damascus at the end of the 7th century was celebrated to both Greek and Arabic Melkites (Violet 1901: 429-430). These Arabic-speaking Melkites were probably migrants, that is, Arabs belonging to tribes which had settled in Syria some centuries before the Muslim conquest of the Levant (Nau 1933: 40-85; Monferrer-Sala 2012: 454). In the 7th century, however, the process of Arabization was rather superficial, as evidenced by the manuscript of Qubbat al-Hazna, in which Greek rather than Arabic characters were used to write the Arabic text. Nevertheless, the Arabization of the Melkites was an ongoing process that began at the end of the 7th century with a linguistic form called Nabatî Arabic, which is assumed to be the "precursor" of the neo-Arabic language (Corriente 2007: 319). However, one more century had to pass before the Melkite structures and hierarchy were Arabized (Samir 1987: 439-441), as demonstrated by the entire corpus of anonymous translations from Greek into Arabic made in the 8th and 9th centuries in Syria and Palestine (for more on this subject, see Sections 3.4.2 and 4.3.2).

Since most of Egypt's Christians were Copts and the Byzantine Empire had no influence there after the Arab conquests, the iconoclastic crisis did not affect the country on the Nile. The iconoclastic crisis in the Byzantine Empire was not reproduced among Egyptian Christians, either Copts or Melkites. On the contrary, the ecclesiastical authorities of all Christian denominations in the Middle East and Africa, while systematically learning about the dramatic course of iconoclasm in Byzantium, avoided such internal confrontation. In this way, they wanted to preserve the unity of their communities and avoid being weakened in the eyes of the Muslim authorities. Basically, the bishops allowed for the cult of icons, but it was by no means exhibited. It is possible that such an approach was due to the precaution against Muslim iconophobia (Codoñer 2013: 136). 


\subsubsection{The patriarchate of Jerusalem}

Palestine, conquered by Muslims, gradually began to change its Christian character. The ties with Byzantium were replaced by ties with the new centres of power: with Damascus, and, after the fall of the Umayyads, with Baghdad (Gil 1996: 1-37). This process unfolded progressively but calmly, "in small steps." Like many other cities in Little Asia, Jerusalem in the first century after the Arab conquest retained its former Christian character with strong Greek accents. Traditionally, this small patriarch consisted of three metropolises and about 68 bishoprics (Troupeau 1999: 341).

The Arab conquest seriously disturbed the structure of the patriarchy. The number of Melkites decreased considerably. Due to financial shortages and the direct patronage of the Byzantine Emperor, the traditional structure of the patriarchate was replaced with a new organizational model. Many titular bishops were appointed, who resided at the patriarchal court. In addition, 25 active autocephalous archbishops were appointed to care for the most venerable and known holy places to Christians. The Melkite patriarchate of Jerusalem was determined to maintain its position as the guardian of the holy places of Palestine, that is, to pursue the mission for which it was established under the new circumstances (LevyRubin 2003: 197-226).

The reconstruction of the chronology of the patriarchs of Jerusalem in the period $634-750$ poses many problems due to either the lack of sources or ambiguities. Nevertheless, it can be represented as follows (Fortescue 1910: 355-364; Dowling 1913: 164-177; Grumel 1958: 451-452):

$\begin{array}{ll}\begin{array}{l}\text { Sophronius I } \\ \text { sede vacante }\end{array} & \begin{array}{l}633 / 634-638 \\ 638-693[?]-\text { Patriarchal Vicar John of Philadelphia } \\ \text { (d.649?) and Stephen of Dora (after 649-?), }\end{array} \\ \text { Anastasius II } & 681 / 693[?]-705 \text { [706?] } \\ \text { John V } & 705[706]-735 \\ \text { sede vacante [?] } & 735-745[752 ?] \text { John VI [?] } \\ & \text { John V= John VI [?] } \\ \text { Theodore I } & 745[752 ?]-770\end{array}$

List of Melkite patriarchs of Jerusalem, 634-750

Table 3.3 Structure of the Melkite patriarchate of Jerusalem

\begin{tabular}{lll}
\hline Byzantine province & Metropolitan bishopric & Number of dioceses \\
\hline Palestina Prima & Caeserea & 32 \\
Palestina Secunda & Scytopolis & 22 \\
Palestine Tertia & Petra & 14 \\
\hline
\end{tabular}

The reorganization of the patriarchate 
The paradoxes of Muslim conquest: province and Jerusalem

The evolution of Muslim claims to Jerusalem
Jerusalem had been closing its gates to Arabs longer than other cities in Syria and Palestine. The Muslims made siege attempts, but analysis of historical sources shows that Jerusalem was not conquered by violent invasion. Melkites surrendered to Arab troops and negotiated with Muslim leaders (Gil 1996: 6-9). Contrary to the Arab plunder of the provinces (Schick 1995: 69-72; Kaegi 1992b: 100-102; Gil 1996: 5), the city suffered no major damage. Moreover, archaeological studies indicate that the Melkites in the early Muslim period of Jerusalem were not second-class residents. As evidenced by the preservation of a prominently located neighbourhood and the erection of new church buildings in this part of Jerusalem during the early Islamic era, local Christian communities maintained their leading position in the city. The Christians functioned similarly to the Byzantine era and the churches dominated the city landscape (Avni 2011: 397-399).

Nevertheless, at this time, Arabs took actions which gave rise to Muslim claims to Jerusalem, which influenced the further fate of the city, namely, the tradition of al-'Isrā 'wal-Mi 'rāăg, two parts of the socalled night voyage of the Prophet. According to Muslim theologians, Muhammad held it overnight, around 621.

The problem is that at the time of the Muslim conquest, not only did no official edition of the Qur'ann exist, but also the traditions using the al-Isra surah contained a vague record of this event. More details were included in the hadith collections that were created some 200 years later. All of this was happening in the context of the systematic, slow introduction of Islam in Palestine. It seems that some of the non-theological elements later influenced theological and legal sources. It is hard to know exactly when the Muslim authorities determined that this "most distant place" is located in Jerusalem. The square where this "night journey" of the Prophet was supposed to end was also identified, and this is where al-masğid al-'aqșā was built. However, after the Arabs entered Jerusalem, a modest prayer room for Muslims was created. It functioned for quite a long time after Frankish Bishop Arculf (later 7th century) toured the Levant around 680. He left us a description of this first mosque in Jerusalem, mentioning that "in the neighbourhood of the wall from the east, the Saracens now frequent a four-sided house of prayer, which they have built crudely, constructing it by raising boards and great beams on some remains of ruins: this house can, it is said, hold three thousand men at once" (Arculfus 1895: 4-5).

In this situation, an ideological dimension was also born: Jerusalem was full of Melkite Churches that obscured the first mosques with their splendour. Wishing to give Jerusalem an Islamic accent, Caliph 'Abd al-Malik b. Marwān ordered the construction of 
a new mosque dome to compete with the magnificent Church of the Resurrection (Church of the Anastasis) and the Chapel of the Ascension on the Mount of Olives. For this purpose, he even brought architects from Byzantium, because Muslims were unable to erect such a building (Gil 1992: 92).

Over time, the second part of the revelation about the "night journey" of the Prophet, called the "ascension" of Muhammad from the rock (al-Mi răg $\breve{g}$ ), was given. Muslim theologians indicated again where this was supposed to have happened (Dermenghem 1955: 114-126). It was the rock terrace on which the Jewish temple of Solomon was thought to have previously stood. There were also numerous legends about this rock. This rock was said to be the centre of the world, the entrance to the Garden of Eden and the source of fertility. The site was where Emperor Heraclius (610-641) probably decided to erect an octagonal church after the liberation of Jerusalem from the Persian occupation. The Byzantines only managed to start construction, before it was interrupted by the Arab invasion. It was on these foundations that 'Abd al-Malik b. Marwān began to build a new temple in 688 (Rosen-Ayalon 1996: 387; Ess 1992: 89-104; Peters 1986; Hasson 1996: 352-357).

During this period, the Melkite patriarchate of Jerusalem maintained ties with Rome. Disputes on doctrine and the Arab invasion were closely watched in the West. Due to the pilgrimage movement, Rome was keenly interested in the affairs of Palestine. In a few cases, not Constantinople, but the popes who were fighting Monotheletism contributed to the strengthening of the Jerusalem hierarchy (Amann 1924: 1000). Although the pilgrimage movement to the Holy Land weakened as a result of the Arab-Byzantine wars, we still have several testimonies from the 7 th century about the pilgrimages made at that time. Around 680 (670?), the aforementioned Arculf (probably Bishop of Périgueux) made a pilgrimage to Jerusalem, where he stayed for nine months. However, according to some hagiographic sources, pilgrims from England also flocked to the Holy Land.

However, Rome's contacts with the Melkites were hampered by political and technical reasons. This is illustrated by the example of St Willibald bishop of Eichstätt (c. 700-c. 787). In 722, he travelled from Regium to Palestine aboard an Egyptian ship. The ship spent the whole winter in Lycia, then stayed in Cyprus for a long time, and finally reached Syria. In Emesa, Willibald and his companions were detained by Muslims as spies. It was only through the intercession of some Spanish apostate that they escaped prison and finally reached Jerusalem in 724, where they stayed for two years. Then they managed to board a ship sailing from Tyre to Constantinople, but spent the next two years in the capital of Byzantium. They returned to

Relationships between Melkite Jerusalem and Rome 


\section{4}

The situation of the Melkite Church

Melkite pope and Rome-Jerusalem interactions

The vacant patriarchal capital
Rome with the retinue of the papal legate and the imperial ambassador in 729 (Bréhier 1928: 21).

Thus, Willibald's pilgrimage lasted seven years, and his adventures show us the difficulty Palestinian Melkites had communicating with Rome in the first half of the 8th century. Despite these difficulties, the popes had always had an interest in the Holy Land. It is known that the above-mentioned Pope Martin I (649-655) sent financial support to the Melkites (Epistola ad Theodorum 1763: 849-850).

Sophronius, who ruled the Melkite patriarchate of Jerusalem from 634, was one of the first bishops to strongly oppose Monotheletism. He participated in the negotiations with the victorious Arabs in 638 and died in the same year (Grumel 1958: 451). After his death, the Melkite bishop Sergius of Jaffa played a great role as an open supporter of Monotheletism. For this reason, the Melkites from Jerusalem complained in Rome to Pope Theodore I (642-649). This pope, however, was a Greek Melkite who was born in Jerusalem and probably came to Rome as a fugitive from the Muslim invasion (Bradshaw 2003: 5). There is a very interesting mention from Liber Pontificalis that Pope Theodore was the son of Theodore, who was the Melkite bishop of Jerusalem: "Theodorus, natione Grecus, ex patre Theodoro episcopo de civitate Hierusolima" (Liber Pontificalis 1886: 1: 330). It is understandable that under these circumstances, when a Melkite was on the papal throne, it was easier for Rome to intervene in Jerusalem's affairs. The pope appointed Stephen of Dora vicar of the patriarchal throne in Jerusalem (Concilium Constantinopolitanum III 1765a: 805-830; Concilium Constantinopolitanum 1765b: 830-832). Stephen of Dora went to Pope Martin in Rome to obtain a nomination of the patriarchal vicar of the Church of Jerusalem for Bishop John of Philadelphia. Pope Martin gave his consent and sent letters asking the clergy to recognize John. Since that date, we do not have any sources on the patriarchate of Jerusalem until AD 705. During this period, it is only known that a certain Anastasius (Anastasius II 681/693 [?]-705 [706?]) signed the document (as patriarch?) during the Council of 692 in Constantinople. Then Jerusalem was relegated to fifth place in the ranks of patriarchates. The small Jerusalem patriarchate was administered by John, bishop of Philadelphia, who probably died in 649 (Theophanes 1885: 270; Amann 1926: 1000; Grumel 1958: 451).

Like the patriarchs of Antioch and Alexandria, Jerusalem also had a long vacancy, and remained without a patriarch until 705 . For more than 50 years, it was administered by vicars appointed by Rome and Constantinople. In 705, John V (705-735) finally ascended the patriarchal throne; he was a friend of John of Damascus, whom he ordained a priest. This patriarch also supported John of Damascus in his fight against iconoclasm and helped to write treatises against this trend (Ioannes Hierosolymitanum 1864: 
1347-1362). During his patriarchal rule, John, who was extremely devoted to Islam, confronted Caliph 'Umar II. His short reign (717-720) was marked by serious restrictions on the freedom of Christians and a great support of the Islamization of Christian enclaves. John V died in 735. It is not known, however, whether his successor was certainly John VI, which is why some historians claim that John V and John VI are the same person (Gil 1992: 683-685). However, after the death of this hierarch, there was probably another vacancy in the capital of Jerusalem until 745 (or 752?), when Theodore I (745-770 [767?]) took the office of patriarch (Nasrallah, Haddad 1996: 55).

Iconoclasm surprised the Melkites of Jerusalem with the planned destruction of images that had previously been found acceptable. It is possible that the destruction of the opulent interior of Jerusalem churches was not imagined. Basically, in the 8th century, the Jerusalem patriarchate lay beyond the sphere of direct influence of the Byzantine emperor, and therefore, did not succumb to iconoclasm. Iconoclasm created widespread dissent among the clergy, and the Church of Jerusalem itself ultimately played a leading role in the iconoclastic dispute, being an ardent supporter of the worship of holy images, as evidenced by the attitude of the patriarch of Jerusalem, John V.

There is basically no evidence that iconoclasm found support in the territories of the Jerusalem patriarchate. The ensuing destruction of the figurative paintings on the mosaics of the Palestinian churches in the 9th century was not the result of iconoclastic activity. However, simplifications should be avoided because the problem of iconoclasm was not completely unknown there, and probably there were also Christians "who simply did not consider icon worship a part of their credo" (Codoñer 2013: 187).

\subsection{Melkite monasteries and theology}

The monasteries belonging to various churches, large numbers of which existed in Syria, Palestine, and Egypt (Chitty 1966), did not disappear rapidly after the Arab conquest, but continued their mission under Muslim rule. They formed a religious and theological basis contributing to the survival of Christianity, especially in difficult periods.

\subsubsection{The condition of Melkite monasteries}

During the Arab conquests, monastic life from Syria to Egypt was well-established and developed. The hermits also commanded general respect in the Christian communities. Paradoxically, the

Monasticism on the eve of the Arab conquests

Monasticism as the source of Christian-Muslim interaction 
early Muslim conquest did not change the monks' situation much. Although the Qur'ān speaks quite unfavourably of monastic life in 9.34 ("Indeed many of the scribes and monks wrongfully eat up the people's wealth, and bar [them] from the way of Allah"), it accepts, however, servants "who spend the night making obeisances to their Lord" in surah 25.63-65. The development of Muslim asceticism (zuhd) was probably strictly influenced by Christian hermits encountered by Muslims in pre-Islamic hanīfs, who practiced monotheism and ascetic life in the pre-Muslim period. Moreover, the Muslim conquests influenced the development of Muslim asceticism in another way. They caused the enrichment of many Muslims, which allowed them to live in luxury. Consequently, devout Muslims appealed to return to the modest lifestyle of the Prophet and his pious Companions. It is difficult to establish the dating and ranges of the earliest Christian-Muslim interactions in the context of asceticism (Livne-Kafri 1996: 105-129). It is supposed that the Melkite monks from the vicinity of Jerusalem were a model for asceticism of Ibrāhīm b. Adham (c. 718-782), one of the most prominent early Muslim ascetics, (Goitein 1966: 140-148). Traces of Christian asceticism can be found in the works of the ascetic, theologian, mystic, scholar, preacher, judge, and exegete Abū Sa '̄id al-Hasan b. Abī al-Ḥasan al-Bașrī (642-728), whose advice became the basic "manual" of Muslim ascetics for a long time. Muslim traditions say that Caliph 'Umar II himself (who, paradoxically, was rather infamous for his favour to Christians), used to dress like a monk (Livne-Kafri 1996: 110).

Abū Bakr 'Abdallāh b. Abī Quhāfa al-Siddīq (632-634) had given the order to treat monks gently. Until the beginning of the 8 th century, monasteries were also exempt from taxes.

Long-term consequences of the Arab conquest for monasticism
The Persian occupation (614-628) and the Arab invasion (634-638) influenced the stability of the structures of the Melkite Church, including monasteries. In addition to the thousands of Melkites killed, many Christians were deported to Persia (including Patriarch Zacharias) or sold into slavery. A monk, Antiochus Strategos (turn of the 6th and 7th centuries), witnessed the Persian activity in Jerusalem and described it as "unprecedented looting and sacrilege." He added that "Church after church was burnt down alongside the innumerable Christian artefacts which were stolen or damaged by the ensuing arson" (Antiochus Strategos 1910: 502-517). However, information from sources about the widespread destruction of churches should be treated carefully, as this practice has not been clearly confirmed by archaeologists (Avni 2010). In turn, the destruction of churches and monasteries during the Arab invasion in 634 was predatory and affected certain churches and monasteries. That is why, in one of his 


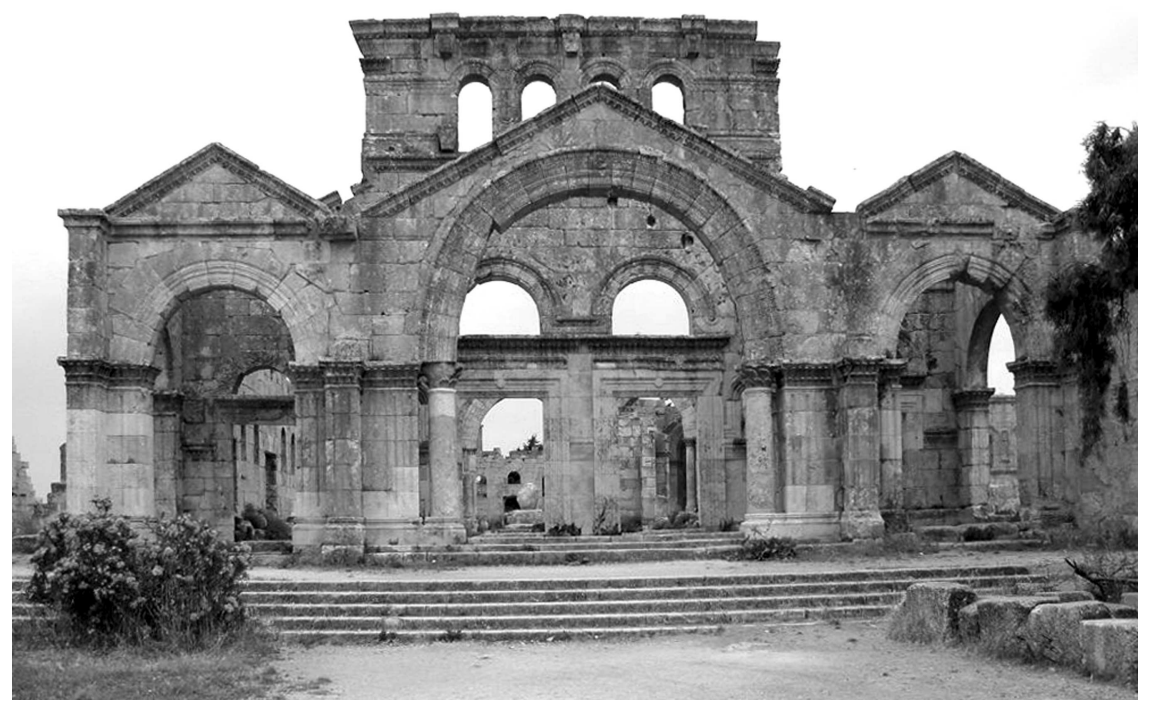

Figure 3.4 Monastery complex of Saint Simeon Stylites (Qal'at Sim ān): basilica (the author's private collection).

famous sermons, the Melkite Patriarch Sophronius asked rhetorically, "Why are the churches destroyed and the Cross profaned?" (Schönborn 1972: 91). In the sermon, Patriarch Sophronius warned the audience that poor Arab Bedouins were scattered around Jerusalem and the journey to nearby Bethlehem was dangerous. It is possible that his sermon was one of the requests for Heraclius to come to the aid of Palestine (Sharon 2004: 302). However, it is difficult to say how this bleak image of the destruction of monasteries corresponded to the reality, and to what extent the Byzantine intention was to recapture the Holy Land from the hands of the Bedouins, who caused such a terrible scale of destruction. Nevertheless, all these unfavourable circumstances caused a decrease in the number of religious vocations after 638 . This, in turn, led to the closure of several monasteries. Even the largest and most flourishing monastic complex in Syria, the monastery of Saint Simeon Stylites (Qal'at Sim'ān), was hit by a vocational crisis. It seems that this was partly due to the weakened pilgrimage movement (Nasrallah, Haddad 1996: 61).

Melkite monasteries in the south (Palestine, Sinai) were located in deserts. Their almost complete isolation was an asset and always attracted Christians who wanted to radically implement the ideals of the Gospel. There, too, the vocational crisis was felt, but to a lesser extent. The monks devoted themselves to their work in the gardens and to prayer, study, and the celebration of the sacraments. They 


\section{8}

The situation of the Melkite Church

knew not only Greek and Syrian, but also Arabic. It is purported that there were also vocations to religious life among Arabs who later made the first translations of the Bible and Greek patristic thought into Arabic. There were two most prominent Melkite monasteries: the monastery of St Catherine in Sinai and the monastery of Mār Sābā in Palestine (Nasrallah, Haddad 1996: 62). Other famous monasteries of the Melkite Church included the monasteries of St Chariton, St Theodosius, St Euthymius and St Anastasius.

Muslim treatment of the Monastery of St Catherine in Sinai
Soon after the Muslim conquests began, the monks of St Catherine's monastery in Sinai, under the guarantee of freedom of worship they received from the conquerors, were receiving pilgrims and charging them. Tradition speaks of the so-called Covenant or Testament of Muhammad, a specific statute, whose authorship tradition attributed to 'Alī b. Abī Țâlib (656-661). The text was allegedly ratified by Muhammad himself. The prophet was supposed to guarantee full protection and other privileges to the monks from the monastery of St Catherine). The document, written in the fourth year of the Hijra (c. 625), was consistently accepted and maintained for centuries by them (the tradition of monks speaks of Muhammad himself visiting the monastery). The creation of this document in 625 or 630 did not sound entirely convincing to historians, who have long questioned the authenticity of this text (Mubasher 2018: 313; Mouton 1998: 177).

In fact, it is one of the few cases of compliance of the Christian and Muslim traditions on which both sides have relied. Considering its importance before its historicity, it certainly showed MuslimChristian relations in a positive light. The monks were able to refer to a document whose authenticity would not be undermined by the Muslim authorities.

However, the surrounding wasteland was inhabited by Bedouins, who looked greedily at the rich monastery. No wonder, then, that more than once it fell victim to bandit attacks by nomads who had nothing to do with the official treatment of the monastery by the Muslim authorities. Despite these difficulties, the Sinai monastery welcomed many pilgrims. It also happened that 600 or even 800 pilgrims were there at the same time (Pargoire 1971: 239). This monastery had its own library and scriptorium, but we do not know the date of their foundation. There, first of all, liturgical texts, rules of religious life, psalter, and Gospel texts were transcribed and collected. Sometimes the monks asked other monasteries for help in rewriting texts. By the 6th century, the monastery of St Catherine had a large library for its time. However, repeated Bedouin raids contributed to the destruction of the texts; for this reason, at certain times, the monastery was even abandoned. Nevertheless, manuscripts 
from the period from the 6 th to the 17 th centuries have survived to this day (Prévost 1937: 109).

The rural monasticism was a key element in the Christianization of Byzantine Palestine (Bar 2005: 49-65). It is estimated that at the time of the Muslim conquest of Palestine, the Judean Desert was an area of exceptional monastic development, with about 130 monasteries being established (Troupeau 1999: 335). The Melkite patriarchate of Jerusalem was proud of the famous monastery of Mār Sābā. This monastery had a great influence not only in Palestine, but also in the entire Middle East (Leroy 1957: 91-121; Hirschfeld 1992; Patrich 1994). This centre played an enormous role in many important theological disputes and political/religious crises, such as "Monophysitism," Origenism, Monotheletism, and iconoclasm. This is evidenced for example by a document addressed to the fathers of the Lateran Synod (649). The abbot of Mār Sābā assigned it the first place among the monasteries of the Holy Land: "Joannes abba presbyter monasterii patris nostri sancti Sabbae, postulans manu subscripsi” (Libellus monachorum 1763: 909). The monastery enjoyed a great reputation for being visited by novices from all over the world, who prayed in their own languages (which, according to Cyril of Scythopolis [c. 524-560], was already agreed by Saint Saba [d. 532]). In terms of nationality, the core of the Mār Sābā religious community were the Melkites from the urban environs of Palestine and Syria, and the Greeks from Asia Minor (sometimes candidates of Syriac origin had great difficulties in mastering Greek). The monastery was famous for its incredible creativity in the fields of Greek hagiographic, dogmatic, and liturgical literature (Kyrillos von Skythopolis 1939: 85-200; Ehrhard 1893: 32-79; Vailhé 1898: 1-11, 33-46; Bagatti 1968: 83-85; Corbo 1958: 215-257; Nasrallah, Haddad 1996: 64-65; Chitty 1980: 212-216, 218-223, 230-231, 244-253, 277-279, 289-291, 303-304, 312, 331, 344-346).

It is believed that Melkite monasteries had Arab monks coming from the Arab tribes and living in the eastern border areas of Byzantium. It is no wonder, especially since the geographic location of these monasteries favoured contact with nomads. The relations between the Bedouins and the monks ranged from armed conflicts from the nomads attacking the monasteries, then through cultural influences, to religious aspects. Arab monks who were spiritually formed in monasteries were the first to create apologetic and hagiographic works in Arabic, beginning in the 8th century, when Islam became a real threat to Christianity (Nasrallah, Haddad 1996: 66).

The oldest Christian texts written in Arabic are apologetic treatises, which also contain the oldest excerpts of the Arabic translation of the Bible. The anonymous Melkite apology published by Margaret Dunlop Gibson in 1899 ( $F \bar{l}$ tathlī Allāh al-wāḥid [On the Triune Nature of God]) dates back to 753 and is considered

"Melkite Pearl of the East": monastery of St Saba

Monks in Melkite monasteries of Arab origin

The oldest Christian Arabic manuscripts 
Influence of monasteries on nomads: the legend of Bahira one of the oldest Christian Arab texts (Tarras 2017: 79). From the same period (though sometimes dated back to the first half of the 8th century) comes the Schott-Reinhardt papyrus No. 438 (the University Library of Heidelberg), which contains the MuslimChristian controversy. A stylistic analysis of this passage indicates that the text was written by an Arab Christian. Scholars confirm the early connections of the still developing literary Arabic language with Christianity, represented by monastic communities (Graf 1934: 1-31; Griffith 1985: 331-374).

It is assumed that the strongest influence of Christianity on Arabs was exerted by monasticism. The ideal of a monk who replaced the martyr from antiquity captivated the Arabs. The holy hermit renounced the world and came to live in the wilderness, that is, in the natural homeland of the Bedouins. For this reason, since the 4th century, monks had penetrated areas inhabited by Arabs which the institutionalized Church could not enter. In this way, a monastery had a greater importance in the spiritual life of Arabs than the hierarchical church entangled in Christological disputes. The monastery was also a place where two ideals interacted: Christian philanthropy and Arab hospitality (Shahid 1989: 404-409; 1995: 171-176, 201-212, 216-217).

The legend of Sergius Bahīrā is of great prominence to historians of monasticism in the Byzantine borderlands. This story is considered an example of the influence of Christian monasteries on Arab nomads (Nasrallah, Haddad 1996: 68, Lammens 1930: 248). This tradition is known in the Muslim version and numerous Christian versions (the latter written in Greek and Syriac). According to the Muslim tradition, the monk Bahīrā met Muhammad on his trip to Syria. Bahịrā apparently recognized the 12-year-old Muhammad as a prophet, foretold his future and protected him from the Jews (according to other versions, from the Byzantines). This account later became more and more embellished, until it was stated that the Prophet was taught by a Christian monk. In turn, the Christian version of the legend of Bahīina served to confirm the falsehood of Muhammad's mission. In the Melkite versions, Bahīrā was portrayed as a "Nestorian" heretic, but in some versions as a "Jacobite" or even an Arian, and sometimes even as a co-creator of the Islamic doctrine. Bahira is mentioned quite early in Byzantine historical and polemical literature under various names (Theophanes 1885: 33; Gottheil 1903; Roggema 2009; Szilágyi 2008: 169-214; Abel 1945: 1-12; Griffith 1995: 146-174).

Without going into the complexities of different traditions, this legendary story has an eminently apologetic nature on both the Muslim and Christian side. Moreover, the Christian versions contain polemical "settlements" between Melkites, "Nestorians," and 
"Jacobites." Regardless of the quality of the arguments, the fact remains that the monk appears as a topos in all accounts. He has authority and he is the representative of Christianity. This shows also a great ideological influence on the Bedouins. It seems that this presence of Christian monks among the Arab Bedouins contributed also to the penetration of Greek and Syriac terminology into the Arabic language, the scope of which is relatively rich in Quranic Arabic_Fuṣhā (Turek 2002: 237-252).

The involvement of monasteries in the development of Arabic literature raises the question of the extent to which particular languages were used in Syria. Research shows that shortly after the arrival of the Arabs, there was a dramatic change: national languages systematically gave way to Arabic. First of all, the traditional Syriac language was rapidly disappearing, especially among the Melkites. Bar Hebraeus distinguished three basic dialects of this language. It follows that in the early Middle Ages there was a systematic differentiation in Syrian, it seems, due to the mutual separation of Christian communities using this language. In Egypt, too, there was a process of systematic marginalization, first of Greek, and later also of Coptic (Nasrallah, Haddad 1996: 68-69; Desreumaux 1983: 341-347).

With the start of Arabization by the Umayyad caliphs, the Melkites encouraged cultural adaptation relatively quickly. This specific "Melkite cultural policy" is sometimes called "the Christian Arab legacy": al-turāt al- 'arab̄i (Monferrer-Sala 2012: 453). In the 8th century, this acculturation was completed as the Melkites not only translated Greek works into Arabic, but also created new works in Arabic. More precisely, the Melkite textual production in Arabic started in the second half of the 8th century (Monferrer-Sala 2012: 458). Paradoxically, Arabization contributed to the consolidation of a separate identity of the Melkites, protecting them from both the danger of complete assimilation with the Byzantine culture and Islamization. The Christian Arabic had its own specific features, thus becoming a carrier of Melkite culture (Versteegh 1997: 124; Monferrer-Sala 2012: 453).

About a century after the Muslim conquest, Arabic began to be more popular among the Melkites in Syria, replacing Greek and Syriac. Of course, it was a process that grew stronger over time. The first sign of the dominance of the Arabic language was theological texts written in Arabic by Christian authors who knew both Arabic and Greek. Although the Arabic language of Christians is full of dialectisms and differs from the artificial rules of the classical Arabic language developed by Muslim linguists, there is no doubt that its use by church writers contributed to the consolidation of Arabic culture in the Middle East (Blau 1961; Graf 1905). 
Thus, the Umayyad period initiated the process of Arabization. This was related to the external situation and gained in strength from the end of the 7th century, after Greek was replaced with Arabic in the state administration (Levtzion 1990: 301-302). However, the Arabized Melkites had terminological and linguistic difficulties that were less experienced by Muslims. Followers of Islam, through regular lecture of the Qur'ān and contact with Mecca and Medina, could systematically implement and spread the canons of the classical Arabic language. Christians, on the other hand, found it difficult to express their religious thought in a new language, because, essentially, theology in the East had developed in Greek, Syrian, and Coptic until the Arab conquests. In Syria, this problem became particularly apparent. The Aramaic culture belongs to the Semite world, which made Syriac-Arab contact easier, but the Syriac Christians had difficulties finding adequate terminology in Arabic to express Christian thought (Graf 1954).

In the era of Christological polemics, many Greek terms were adopted into Syriac. In fact, very few Melkites wrote in Syriac, and polemics between Melkites and "Jacobites" took place in both Greek and Syrian (Anastasius Sinaita [died after 700] and Jacob of Edessa [c. 640-708]). However, when polemical and theological texts were written in Arabic, terminological difficulties arose. In order to avoid ambiguity and the "Islamization of thought," Melkite authors did not borrow the Arabic vocabulary from the field of Muslim theology. All of this explains why Melkites and other Oriental Christians used Arabic dialectal forms in written forms.

Visits of Muslims in monasteries

The monasteries as vital cultural centres were also visited by Muslims. However, these visits were rather related to secular purposes: for relaxation, because monasteries were often beautifully situated, for wine tasting (although it is prohibited by Islam), because monks often owned vineyards, or for the experience of religious hospitality, as the monks did not turn anyone away (Kilpatrick 2003: 23). Sometimes Muslims visited monasteries for religious reasons. They most often admired the celebrations of Christian holidays, which, like a magnet, attracted with the beauty of the liturgy and melodies. It also happened that they worshiped the relics of saints. Finally, sometimes they were attracted by the stories of miracles that enjoyed popularity among the people, both Christians and Muslims (Troupeau 1999: 325).

\subsubsection{Melkite "neo-martyrs" and theology in the context of Early Christian-Muslim polemics}

Melkite

"neo-martyrs"
Although the interaction of Oriental churches with Islam was primarily marked by Islamization, it was not only a one-way influence. 
History also knows examples of conversion from Islam to Christianity, usually under dramatic circumstances. Therefore, this interaction was complex, at times characterized even by violence. There are also examples of Christians rejecting the Islamic social and political order. They did so in two principal ways: baptism of some Muslims who left Islam through an act of apostasy or through blasphemy (Sahner 2018). The Melkite communities reported relatively many episodes of this kind in accounts of martyrdom, which modern researchers quite often consider to be stylized hagiographic descriptions of violence (Sahner 2020: 389). Since the beginning of the 20th century, the term "neo-martyr" has been used more and more often (Peteers 1912: 410; Dick 1961: 109; Griffith 1998: 163-207; Sahas 1999: 85; Swanson 2001a: 116; Sahner 2020: 389) to denote the Christian martyrs of the first centuries of Islam as distinct from the victims of the persecutions under the Roman and Sasanian emperors (they could be considered "classical martyrs").

A typical example of the death penalty for blasphemy is the case of a young Melkite monk Michael from the monastery of Mār Sābā, according to the Georgian version, originating from Tiberias in Galilee. Without getting into the colourful details of his biography, it is worth focussing on his final statement at the court of Caliph 'Abd al-Malik: "Muhammad is most certainly not a prophet or an apostle, but an imposter, a deceiver and a forerunner of the anti-Christ" (Stuz 2019: 27). He was beheaded outside Jerusalem (Peteers 1930: 65-98; Griffith 1994: 115-148).

In turn, according to the Old Georgian manuscript, The Life and Martyrdom of Peter of Capitolias, Peter of Capitolias (died 715) was married and had three sons. Together with his family, he chose monastic life. Peter was said to dream of a martyr's death. He made a declaration of faith that contained harsh statements against Islam, first to the Muslims in his own town, then to the emir, and then to the caliph in Damascus. Peter was sentenced to torment and death. His tongue was torn out, his feet and hands were cut off, and he was blinded and crucified. His body was burnt and the ashes were thrown into the river (Sahner 2018: 167; Peteers 1939: 299-333).

It does not seem necessary to discuss other biographies of Melkite martyrs, such as the caliph's cousin Pachomios (died in the 8th century), the craftsman Elias of Heliopolis (759-779), the Byzantine monk Romanos (died 780), the convert Daḥhāq or Bacchus, executed in Jerusalem in 786, the convert Rawh al-Qurašī or Anthony (died 799) or a monk of Mār Sābā, George of Bethlehem, who died in 852 (Samir 1992b: 343-359; Peteers 1912: 410-450; Swanson 2001: 116-118; Dick 1961: 109-133; Griffith 1998: 163-207). These martyrdoms have survived in Greek, Georgian, Arabic, and Latin 
versions and despite some differences, there appears a similar topos. Martyrs bear witness to the faith before the highest officials and figures of the caliphate. They exhibit steadfastness in witnessing the "true faith" and provoke Muslims by criticizing Islam. There also recur "typical" places like Mount Sinai, Mār Sābā, Jerusalem, Damascus, al-Ramla, Balbeek, and ar-Raqqa (Swanson 2001: 118-119). The attempts at establishing the facts from this hagiographic material are limited. Nonetheless, there has long been a debate among researchers of whether and how these stories relate to the realities of the Umayyad era and the early Abbasid caliphate (another reality was [is] the beliefs of Oriental Christians on the subject). According to John C. Lamoreaux, it is almost impossible to speak of Arabic Orthodox (Melkite) hagiography separately from Byzantine hagiography. Arab Christians, Georgians, and Greeks shared a similar tradition and the reality of the 8th and 9th centuries facilitated the transmission of hagiographic works (Hagiography 2014: 112).

In critical research, Marc Swanson, however, proposes "a cuisinard method" of studying hagiographical texts. It is not focussed on the story of the protagonist, whose existence is not the most important, "but the incidental details of social, political, economic, and religious life to which the story bears indirect witness" (Swanson 2001: 120). It is possible that this kind of hagiographic literature was intended to be more didactic than historical. These biographies encouraged people to profess their faith, taught religious truths and persuaded the Melkite audience (Swanson 2001: 121).

Another explanation for the meaning of the Melkite neo-martyrs comes from an analysis of the interaction of the protest against the appropriation of religious symbols. It happened also that various external factors, including some similarities in religious practice, did not always allow Muslims and Christians to distinguish one religious obligation from another. All of this facilitated "the conversion interaction," from Islam to Christianity and from Christianity to Islam. According to Christian Sahner, the "passive conversion" of Elias of Heliopolis (759-779) was accomplished unconsciously or by fraud, simply because of a change in external symbolic factors. The author speaks of "cultural religiosity," which partly explains the phenomenon of neo-martyrs. It was not always a deliberate, personal initiative. The reverse interaction is exemplified by Christians who converted to Islam without hesitation, more because of "cultural change" than because of doctrine (Sahner 2018: 33-34).

However, not all conversions can be explained as a "cultural" phenomenon. There were some significant cases of people who had had experience of both religions. They finally recognized Islam or 
Christianity because of the deep theological convictions that can be drawn from apologetic statements or justifications of decisions. It seems that the Melkite neo-martyr ethos was, in fact, a dramatic attempt to defend Orthodox Christian identity in the crucible of change in the 8th and 9th centuries. This defence was so important that it even demanded hostile resistance to the "Muslim oppressor," to the point of martyrdom. In this way, the Melkite neo-martyrs became a symbol of active resistance.

Strongly connected with Greek culture, the Melkites had always had educated theologians, although, not all of them were remembered as outstanding scholars. There were many bishops who fought against dogmatic errors and argued with Muslims. Unfortunately, most of their works have not survived to our times. It is, therefore, appropriate to limit ourselves to the most outstanding figures whose works have survived or about whom we have reliable information. However, the discussions were not always limited to refuting specific allegations. An anonymous "Melkite Apology for Christianity" written in the 740s in Palestine is more a discourse addressed to Muslims than a debate with questions and answers (Beaumont 2005: 17-18).

It is worth starting the analysis of the Melkite polemical texts with Peter of Damascus (c. 675-c. 749). His identification stirs up discussions among historians, who sometimes consider him quite a mysterious author, confused with other persons such as Peter of Capitolias (Peeters 1939: 299-333; Peters 2011). The most convincing testimony to the existence of this theologian is found in the work Libellus de recta sententia. John of Damascus drafts a confession of faith that Elias, bishop of Yabrūd, who abandoned Monotheletism, made in the presence of Bishop Peter of Damascus (Joannes Damascenus 1864a: 1421-1432). Moreover, John of Damascus, on behalf of Bishop Peter of Damascus, wrote a polemical treatise against the "Jacobites" to the "Monophysite" bishop of Dārā (Joannes Damascenus 1864b: 1135-1502). The treaty between the inhabitants of Damascus and the Arabs in 635 was negotiated by the priest Manșūr b. Sarğūn and an unnamed bishop of Damascus, who was, as is commonly assumed, just Peter. There is also the mention, that the Caliph al-Walīd had ordered Peter's tongue to be cut off and Peter exiled to South Arabia, where he died as a prisoner (Theophanes 1885: 270-271). Peter of Damascus left us an apologetic work against Manichaeism and Islam. It is credible that this is the work included in the manuscript Sin. gr. 343 in the monastery of St Catherine. Another Peter, called Capitolias, also a martyr during the reign of al-Walīd, left an Explanation of Christian Dogmas (the Sinai manuscript Sin. gr. 441, treaty 3, Nasrallah, Haddad 1996: 78-79).

Undoubtedly, the most outstanding Melkite theologian of the Umayyad era was John of Damascus (c. 650-750). He came from an

Peter of Damascus 
Arab Melkite family and his father managed the finances of the Arab administration. Well-educated, John of Damascus knew Greek and Arabic, having been familiar with Christian theology, culture and philosophy as well as Islam. For some time, he worked as a clerk in the state administration and represented the interests of Christians before the Muslim authorities. In about AD 700, as a result of "purges" in the administration related to the anti-Christian ordinances of Caliph 'Abd al-Malik, he was forced to resign from office (some authors situate these events in the period of administrative arrest during the reign of Caliph 'Umar II [717-720]). It is worth remembering that some researchers have objected to the authenticity of the sources about the removal of Christians from the administration of the caliphate. The edict attributed to 'Umar II is considered to be internally inconsistent, and the letters are thought to be pseudo-epigraphs from the Abbāsid period. At best, historians believe that 'Umar II took some actions unfavourable to Christian bureaucrats; however, the facts of these events cannot be recreated (199-200).

After these events, John of Damascus entered the monastery of St Saba in Palestine, where he stayed from 718 to 720 . He was ordained a priest by the patriarch of Jerusalem, John V (705-735) around 725. He became famous as an outstanding scholar, polemicist with Islam, poet, preacher, advisor to bishops, and a fearless defender of the cult of images (Joannes Damascenus 1864a: 1421-1432; 1864b: 1135-1502; 1864c: 529-676; 1864d: 677-780; 1864e: 789-1228; 1864f: 336-337; 1864g: 417-438; 1864h: 1231-1420). He is considered to be one of the last outstanding theologians of the Greek Church, although he did not create any new, original system, but only consolidated the rich heritage of patristic theology. In fact, his work contains traces of theology, mostly by the Greek Church fathers. There is a vast number of studies on John's output from the theological and historical points of view, as well as on Muslim-Christian relations (see e.g. Sahas 1996: 229-238; Schadler 2017; Nasrallah, Haddad 1996: 120; Nasrallah 1950: 161-162, 166-167; Kötter 1959: 224-234; Janosik 2016; Louth 2002; 2003; 2005; Sahas 1972; Kontouma 2015; Olewinski 2004; Richter 1964; Beaumont 2005: 12-16).

An important part of the output of St John of Damascus is his polemical writings (De hymno trishagio, De natura composita contra Acephalos, Contra Jacobitas, Disceptatio Christiani et Saraceni) directed primarily against Manichaeism, Monotheletism, "Nestorianism," and Islam. It is particularly interesting that this saint includes Islam as a heresy in chapter 101 of his De haeresibus. Sometimes the Arabic text described as "Rejection of Muslim claims" (Khoury 1969b: 48), whose manuscript is kept in the Vatican Library (Vat. arab. 175, Mai 1825, vol. 4 part. 2, 323) and in two codices in a private collection in Aleppo 
(Al-Fihris 585, 586: Nasrallah, Haddad 1996: 130), is attributed to John of Damascus. Scientists are researching the identification of this work. It is possible that it was written in the style of John of Damascus or was later composed on the basis of his teachings.

John of Damascus' polemic against Islam is an extremely popular research topic in the West (Coz 1992; Janosik 2016; Schadler 2017; Sahas 1972). Although some authors try to question the authorship of his anti-Islamic statements (Abel 1963: 5-25; Christiensen 1969: 34-50; King 1966: 76-81), many researchers indicate that their authenticity cannot be disputed (Sahas 1972; Khoury 1969b: 46-82; 1994: 38-69; Meyendorff 1984: 115-132; Merill 1951: 88-97; Voorhis 1934: 391-398; Becker 1924: 432-449). The critique of Islam and Muhammad in De haeresibus 101 is overwhelming: John of Damascus calls Muhammad "a false prophet" and presents his book as containing "ridiculous," "stupid," "lewd," and "absurd" teachings (Jean Damascène 1992: 211, 213, 219, 223, 225). However, apart from these ironic comments, this work also contains elements of a reliable account of Islam, which he learnt from the Muslims themselves. Some researchers speculate that certain passages which contain anti-Islamic epithets, and which deviate from the author's style in other places and works, are a later interpretation.

In addition to a negative judgment of Islam, one can find a lot of accurate information about Islam, including Muhammad's name, albeit in a slightly twisted form, a scripture supposedly sent from heaven, Muhammad's contact with Christian and Jewish teachings and the observation that the ancient Arabs worshiped Aphrodite (Venus) before the rise of Islam (Sahas 1972: 132-134).

John of Damascus' views on Islam are understandable in the historical context in which De haeresibus was written. At that time, the Byzantines fought fierce battles with the Arabs, trying to defend the lands they owned and, if possible, to regain the lands seized by the Muslims. John of Damascus asked God in his hymns to give the Byzantine emperor victory over his enemies, among whom he included the Muslim invaders. This Melkite theologian hoped that Basileus would eventually "trample under his feet the barbarian nations," among which he counted Arabs (Sahas 1996: 229-238; Meyendorff 1984: 117-122). In assessing the Islam of St John of Damascus, he does not hesitate to call him "the messenger of the Antichrist." Thus, he referred to the descriptions of the Last Day in the Apocalypse of St John, just as St Maxim the Confessor (Sahas 2003: 97-116). Earlier, the author described the Byzantine emperor Leo III as Antichrist, who, as mentioned above, opposed the cult of images.

The Arab conquests of the Middle East were not immediately perceived by the Melkites as a permanent occupation. Moreover, it was not fully realized that a new religion, Islam, had entered with

Apocalyptic visions, Melkite hopes for "Byzantine Reconquista" and harsh realism 
the invaders, which would supersede Christianity from many regions over time (Dagron 1999a: 72). When Muslim Arabs arrived in the Middle East, Christians of all denominations of Syria and Palestine were tired of wars with Persia and the political intrigues that were enmeshed in the legacy of Christological disputes. The inhabitants of these regions simply expected stability. Therefore, they gave up resistance to the invader, having received, under the treaties, respect for their churches, faith and a guarantee of preserving their property for taxes. This passivity was supported by the strange politics of the defeated emperor Heraclius, who, having given up the fight, hurriedly left Antioch, taking with him the priceless tree of the Holy Cross, which he had recently brought to Jerusalem. Back then, nothing heralded the events that would soon involve the Melkite Church in the processes of Arabization and Islamization.

Nevertheless, relatively quickly, the departure of the Byzantines and the emergence of a new Muslim state, in which Christians were subjected to restrictions, led some Christians to apocalyptic interpretations (Suermann 1985; Suermann 1987: 140-155). This trend is confirmed, for example, by the revelations of Pseudo-Methodius of Patara, which, according to some scholars, were written in 644 and 678 and translated from Syrian into Greek at the end of the 7th century. The text does not contain confessional controversies, so it was likely composed by a "Nestorian," "Jacobite," or Melkite monk. Worded like a prophecy, the work describes the horrors that the Arab invaders would perpetrate on the inhabitants of the conquered countries. The text seems to represent an early Christian response to the expansion of Islam that appeared to mark the end of the old world. Nevertheless, the reign was seen as a short, transitional epoch after which the Byzantine era (eastern Roman Empire) would continue until the end of the time to come. This Christian response to the difficulties Christians had faced was seen as a punishment from God (Dagron 1999a: 30; Hoyland 1997: 263-267; Griffith 2008: 33).

Although the apocalyptic view of Islam survived the following centuries, by the end of the 7th century, Christian writers began to regard the Arab conquest as an accomplished fact. There was also a gradual shift of emphasis in the vision of Christians in the lands of Islam, which is made evident, for example, by Jacob of Edessa (Drijvers 1994: 104-114; Lamoreaux 1996: 3-31). After the Muslim conquest of the Levant, the divided churches of the Orient continued Christological disputes that strengthened mutual prejudices (Griffith 2001: 9-55). Perhaps that is why in the interpretation of the consequences of the Muslim conquest, polemical 
threads appeared between the Melkites and the "Monophysites." The Monophysite bishop John of Nikiû, terrified that so many Christians were converting to Islam, found that the blame for the Muslim occupation was borne by Melkites who tried to impose orthodoxy in pre-Islamic times.

\subsubsection{The Melkite communities in Persia and Central Asia}

Attempts to recreate the condition of the Melkites beyond the boundaries of the classical patriarchy are full of ambiguity due to the lack of sources. They are also an extremely tricky subject in terms of formulating hypotheses. Owing to population migration and trade contact, the Melkite communities also flourished beyond the former borders of Byzantium. Traditionally, in Mesopotamia and Persia, the "Nestorians" had relatively well-grounded church structures (Erhart 1996: 55-71) and the "Monophysites" also had considerable influence.

The Greeks had lived in the Sassanid state for centuries. The first Greek colonies were established in Persia in the time of Alexander the Great (356-323 BC). During the first centuries of Christianity, the number of Greeks in Mesopotamia and Persia steadily increased. The Greeks arrived as merchants and prisoners of war captured during the long Parthian wars with Rome (Richter 1946: 15-30).

As for the Melkites, historians indicate that most of them were captured from the patriarchy of Antioch. We have testimonies that confirm the presence of Melkite communities in Ctesiphon, Ğundīsāpura and in the province of al-Ahwāz. Over time, Greek settlements spread beyond Khorasan, reaching Šāš (Tashkent). The first information about a Melkite presence in Persia is related to the Byzantine-Sassanid wars in the 6th century. According to Procopius of Caesarea (c. 500-565), during the early reign of Khosrow I (531-579), the Persians not only penetrated the eastern provinces of Byzantium, but also captured Antioch (540), from which they deported most of the inhabitants. They were relocated to the vicinity of Ctesiphon, where they had to build a new city equal to the splendour of Antioch ("Chosroes built a city in Assyria in a place one day's journey distant from the city of Ctesiphon, and he named it the Antioch of Chosroes and settled there all the captives from Antioch"; "Indeed he brought with him charioteers and musicians both from Antioch and from the other Roman cities" (Procopius 2008: 2.9.14; 14.1-4). That city was known as Rūmaghān or Rumagyris - "the city of the Romans" (Parry 2012: 95; Nasrallah, Haddad 1979: 8-9) with 30,000 inhabitants (Brooks 1935-6: 239), according to John of Ephesus (c. 507-588). Many

Persian deportations of the Melkites 
scholars believe that a catholicos resided there. This is supposedly proven by the seal kept at the Bibliothèque Nationale in Paris with the inscription in Pahlavi which Phillppe Gignoux (1931-) read in 1978 as "Great catholicos [of the] region of Hulvān and Balāsagān" (Parry 2012: 95). This testimony, however, is debatable. For some authors, it is proof of the existence of the Melkite catholicos in Central Asia (Fiey 1995, 6-9; Nasrallah, Haddad 1979: 8-9; Klein 1999: 235-65); others believe that the seal is actually unreadable (Frye 1977: 41) or that it is geographically inaccurate, as Balāsagān was a satrapy of the north-western part of the Sasanian Empire extending to the Caucasus mountains (Parry 2012: 95).

Of course, among the deportees to Persia were Christians of various denominations, but considering the fact that in Syria the Greek element was dominant in the cities and the countryside was more Syriac (Aramaic), it can be assumed that Melkites dominated among those captured from Byzantium in the 6th century (Kościelniak 2000b: 41). The situation was different during the Byzantine-Sassanid conflicts in 614-628. The Sassanid occupation of the eastern Byzantine provinces dominated by "Monophysites" in rural regions brought tolerance to anti-Byzantine Christians who sometimes considered Persians more as liberators than oppressors (Parry 2012: 95). The Melkites, as supporters of the Byzantine emperor, were regarded almost as the "fifth column." According to Dionysius of Tel-Mahrē (died 845), "when Chosroes conquered Mesopotamia and expelled the Romans from it, he ordered at the same time the Chalcedonian bishops to be expelled from their churches and those churches to be given to the Jacobites" (Dionysius of Tel-Mahrē 1993: 125). So, if six provinces had even significant Christian populations in the 7th century, including Ray, Abaršahr, and, from the end of the 6th century, also Marv and Herat (Sims-Williams 1992: 327), this usually does not mean Melkite populations.

Historical problem of Melkite bishopric/ catholicate in Ctesiphon
The establishment of Melkite Ctesiphon is an extremely controversial topic. Some modern Melkite historians locate the creation of the Ctesiphon catholicate at the Council of Nicaea (325) because a mysterious John of Persia is mentioned. There is no doubt that there were Christian communities during the early Sassanian period in Persia, but we do not know much about their ecclesial organization. Historians have identified about 20 bishoprics at the beginning of the Sassanid era. However, they were scattered from Bẹt Zabdē in the north through Karkā, Bẹt Selôk and south to Susiana and Mešān (Asmussen 1968: 925). In the 3rd century, Christians appeared in Media, Kāšān and Pārs. However, until the Council of Nicaea in 325, Christianity was not very popular in Persia (Sims-Williams 1992: 327). Besides, until the 
time of Christological disputes in the 5th century, it is also difficult to talk about a Melkite denomination. We do not have reliable sources confirming the Melkite hierarchy in Mesopotamia before the 8th century (Nasrallah, Haddad 1979: 8).

Some authors suppose that between the second half of the 6th century and the year 762 a certain bishop of the Melkite colony of Rümiya assumed the title of catholicos and had many metropolises and bishoprics of Asia under his jurisdiction (Nasrallah, Haddad 1979: 8-9). The question arises, however, where exactly the mysterious Rumagyris (Rümaghān, ager Romanorum) was located. Rumagyris was mentioned by a Byzantine bureaucrat from Antioch, Ibrāhīm b. Yūḥanna (c. 10th/ 11 th century) (Ibrāhīm ibn Yūḥannā al-Anțākī 1952: Vie du patriarche: 23), and by the patriarch of Antioch Peter III, who ascended the patriarchal throne in 1052-1056 (Michael Cerularius 1864: 760). The dispute between historians and orientalists about the location of Rumaghān has not been unequivocally resolved. Some, using Coptic sources, place this bishopric in Šapurgān (today Šibirgān) in Khorasan (Honigmann 1961: 99). Others say that Rumagyris was a district of Nišāpur, the capital of Khorasan (Karalevskij 1924: 612). Finally, there are also those who, on the basis of information provided by Ibrāhīm b. Yūhann, locate Rumagyris in Šāš, in Central Asia, or more precisely around today's Tashkent (Nasrallah 1976b: 44-45). Such a location is also understandable in the light of internal migrations in the Sassanid empire. Unlike the Romans and Byzantines, who commonly sold their captives into slavery, the Persians often used captives to colonize some regions (Parry 2012: 95; Lieu 1986: 475-505; Rotman 2009: 33-35; Morony 2004: 161-79). For this reason, some of the Melkites were exiled to the eastern fringes of the Sassanid Empire.

It is somewhat easier to locate Melkite monastic life in Mesopotamia. Thanks to Syrian and Arabic sources, we know about the existence of Melkite monasteries and churches in the 7th century on the territory of the former Persian empire. First of all, there are two monasteries next to Arrağān. The monks prayed there alternately in Greek and Syriac. In 723, a Melkite Church was built also in Kufa, the foundation of the previously mentioned Iraqi governor Hāalid b. 'Abdallāh al-Qasrī (died 743/4), for his mother, who was a Melkite (rūmiya according to Mārī b. Sulāymān 1896: 1: 66). A Syrian historian and biographer, Abū 'Abd Allāh b. Muḥammad b. Šākir al-Kutubī (1287[?] or 1397[?]-1363), in his 'Uyün at-tawārīh, characterized her as follows: "unfaithful to the Prophet, believing in her priest, cross and baptism" (Nasrallah 1976b: 41). 


\section{The situation of the Melkite Church}

\subsubsection{Sabaites-the Melkites in Rome?}

An intriguing place: San Saba qui appellatur Cella Nova
A critical look at the few sources
Pope Theodore I (642-649), whose election as bishop of Rome is related to migration after the Arab invasion, has already been mentioned (Bradshaw 2003: 5). He certainly originated from the Melkite milieu. In this context, it is also worth noting that in studies on eastern immigrants to Rome, there are quite frequent, sparing mentions of monks from the Palestinian monastery of St Saba.

The presence of Melkite monks in Rome usually dates from 645. That year, fugitive monks from the monastery of St Saba in Palestine were said to come to the "Eternal City" (Urbs Aeterna). Quite often these newcomers are said to have taken part in the Lateran synod (the assembly of 649 is not considered a council by the Western Church). At the end of the synod, these monks, known as the Sabaites, were to settle in the old domus (noble estate) on Piccolo Aventino (the smaller ridge of the Aventine Hill, which was depopulated at that time due to a large decline in the Roman population). Following the Eastern pattern, they set up a hermit cell there (Sansterre 1983: 24-29; Coates-Stephens 2007: 224-226; Bordi 2008: 57-60). This old domus was probably xenodochium (a hostel or a hospital, usually specifically for foreigners or pilgrims) and converted to a church when Palestinian refugee monks settled there by the order of Pope Martin I (649-655) (Bordi 2009: 52). For the sake of clarity, it should also be noted that the most correct name of this church seems to be the descriptive Latin name San Saba qui appellatur Cella Nova (Delle Rose 1986-1987: 65-113; Coates-Stephens 2007: 224). In the literature on the subject, however, it appears relatively often as Cella Nova.

This information deserves closer attention and requires critical evaluation. Although their presence in Rome is not doubtful-the Sabaites, for example, introduced the cult of St Saba-the question arises as to whether the Melkites actually continued their presence in the Roman monastery. There are many indications that they were soon simply replaced by Greek monks. In fact, some authors tend to consider this monastery "Greek" from its inception (Coates-Stephens 2007: 224).

Information about the Melkites in Rome is very sparse and mostly "blended" into the Greco-Byzantine context. Interestingly, the Liber Pontificalis did not record the foundation of the Cella Nova Monastery, but An Early Syriac Life of Maximus the Confessor talks about the handover of this monastery by Pope Martin to foreign monks (Life of Maximus 1973: 318). The Greek context dominates in the documents of the Synod/council of Lateran of 649 (in which the Melkite monks were said to have 
participated), which contain a petition signed by 37 reverendissimi abates, presbyteri et monachi Graeci, jam per annos habitants in hac Romana civitate who wished to participate in the deliberations (Concilium Lateranense Romanum 1763: 903, 905 list of monks 909). The signatures include those of two Sabaite monks (one from Africa). The fact that many petitioners claimed to have been in Africa three years earlier is just as intriguing. This shows several dimensions of the interaction between the Christians of the East and the West in the period in question (Ferrari 1957: 287-8; Sansterre 1983: 9-11; 22-23).

It is difficult to distinguish a "purely Melkite" element in Rome during this period because Greek influences dominated. We should not forget that the synod convened by Martin I in 649 was a continuation of the activities of Melkite Pope Theodore I, who died on 14 May 649, while preparing for the council. Certain influences of the Melkites in Rome, therefore, seem to be in harmony with the events of the epoch. While Pope Theodore did not obtain anything in Constantinople, his writings on Monotheletism were widely echoed. The bishops of Cyprus, the Melkites of Palestine and the bishops of Africa strongly supported the pope's position.

Significantly, the Lateran Synod of 649 dealt primarily with the condemnation of Monotheletism, a Christology advocated by many Eastern Christians. Although the synod did not receive the honourable title of an "ecumenical council" and was not recognized as such either in the East or in the West, it was undoubtedly the first attempt by the pope to convene an ecumenical council independent of the emperor. The irony of the synod of 649 was that the condemnation of the theology of Constantinople came from the continuation of a peculiar "Greco-Palestinian cooperation" and such style of theological discourse fits into a purely Eastern tradition (Ekonomou 2007: 116-131).

The decisions of the synod itself affected the "Greek and Melkite worlds." One hundred and five Western bishops supported by a large group of "exiled" Greek clergymen found the doctrine of the two wills of Christ. Monotheletism and Typos-the edict of Constans II (641-668) prohibiting discussion of the number of Christ's wills - were condemned. The patriarch Sergius I, the patriarch of Constantinople (610-638) was called heretic. The pope took steps to implement the resolutions of the synod: he excommunicated the bishop of Thessalonica, a supporter of the now monotheletist heresy, and appointed a new legate in Palestine, especially in the one-will doctrine of Christ. He sent a letter to the emperor, urging him to reject heresy.

It seems that the presence of the Sabaites in Rome was more accidental than the planned action. Anyway, they quickly blended in with the Greek element of the city. Besides, there are also opinions that Cella Nova was not dedicated to St Saba until the pontificate

Greek or Melkite monastery? Difficulties in identifying Melkite activities and traditions in Rome

The Roman monastery of Saba: Syrian saint (symbol), Greek activity 
of Hadrian I (772-795). Consequently, the presence of Palestinian Melkites in Rome is seen as pure coincidence (Delle Rose 1986-1987: 68-69; 80-81).

Regardless of these criticisms, the Sabaite Monastery prospered well and for a relatively long time. In the 8th and 9th centuries, $\mathrm{St}$ Saba was considered one of the most prestigious "Greek" monasteries in Rome (besides Renati and the enigmatic Domus Arsicia). It received generous financial support from the Pope (Krautheimer 1937: 51). Starting in 680, its abbots undertook diplomatic missions in relations between Rome and Byzantium and represented the Roman Church and the Pope at church assemblies in Constantinople. Especially interesting is the representation of the pope by the monk Leontius of Cella Nova at the 6th Ecoumenical Council of Constantinople (Coates-Stephens 2007: 225-226). 


\section{Melkites in the centralized and disintegrating Abbāsid \\ Caliphate, 750-969}

The German orientalist Gustav Weil (1808-1889) distinguishes the period of real Abbāsid rule from the Abbāsids' accession to the throne in 750 to the Fatimid takeover of Egypt in 969 (Weil 1846-1851). It seems that this division is also practical for outlining the history of the Melkite Church. While the Umayyads made efforts to cement the state by means of Arabization (external element of culture), the Abbāsids, in a way, undertook the work of unifying the empire "from within" through Islamization. To implement the new principles, a new political structure was quickly created. In fact, it was very similar to the Byzantine type of power organization that was destroyed by Muslims during the era of conquest. However, it was impossible without the commitment of non-Arab peoples, because the ethnic, social, and cultural diversity became elements of decentralization in the caliphate.

The Abbāsids, who took the place of the Syrians, came from the Chorosan rebels. Most of their armies were stationed in Iraq, and therefore, Abū al-'Abbās as-Saffāh (749-754) moved the capital of the caliphate from Damascus to Kufa, and his successor, Caliph alManșur (754-775), moved it to Baghdad. The relocation of the Abbāsid capital to Iraq restored many practices straight from the Sassanid administration. It also gave the "Nestorians" and "Jacobites" more opportunity to develop since Melkite Damascus was a provincial city. At any rate, the Syrians felt cheated.

\subsection{The Abbāsid sine wave: double standards of the treatment of Christians}

The Abbassids ruled five times longer than the Umayyads, but it is hard to say whether or not they ruled better. At first, the Arabs (especially Syrians), Persians, and Shi'ites were dissatisfied. Some of the Muslim authors assessed the 8th century as pessimistic. An example of this is the reflective-philosophical poetry (zuhdiyyāt) of Abū

Problems with the legitimacy of the Abbāsid rule 


\section{6}

Melkites in the Abbāsid Caliphate

al- Atāhiyya (748-828), the great observer of common life and morality (Siwiec 2012: 5-170).

The new rulers, having problems with legitimism and feeling insecure as caliphs, made great use of propaganda among the masses, by promoting the belief that if the Abbassid caliphate was destroyed, the whole world would be disorganized. When the propaganda was unsuccessful, they resorted to the most brutal violence and oppression, which Melkites had experienced several times.

Initially, there was relative tolerance in the years of taming the chaos after the Abbassid-Umayyad confrontation. Baghdad became a cosmopolitan city. The caliphs must have had respect for both Sunnis and Shi'ites, as Shi'ite groups fought against the Umayyads alongside the Abbāsids. Christians of different churches still constituted a large part of the population at the time, and although they were not directly a party to the power struggle, their support for the new rulers was also significant (Canard 1962: 267-287).

The golden age of the "Nestorian Church"
The period from Caliph Abū al- 'Abbās as-Safāh's accession to the throne to the reign of al-Mutawakkil (847-861) witnessed the spectacular development of the "Nestorian Church." This success was possible due to a large number of zealous and devoted monks gathered around monastic schools. In Baghdad itself, the "Nestorians" had monasteries and schools with large numbers of students and professors. The most important of them were Deir Kalīlī̌sū, Deïr Mār Fatyūn, and Deïr Karḩ. In the latter two, medicine

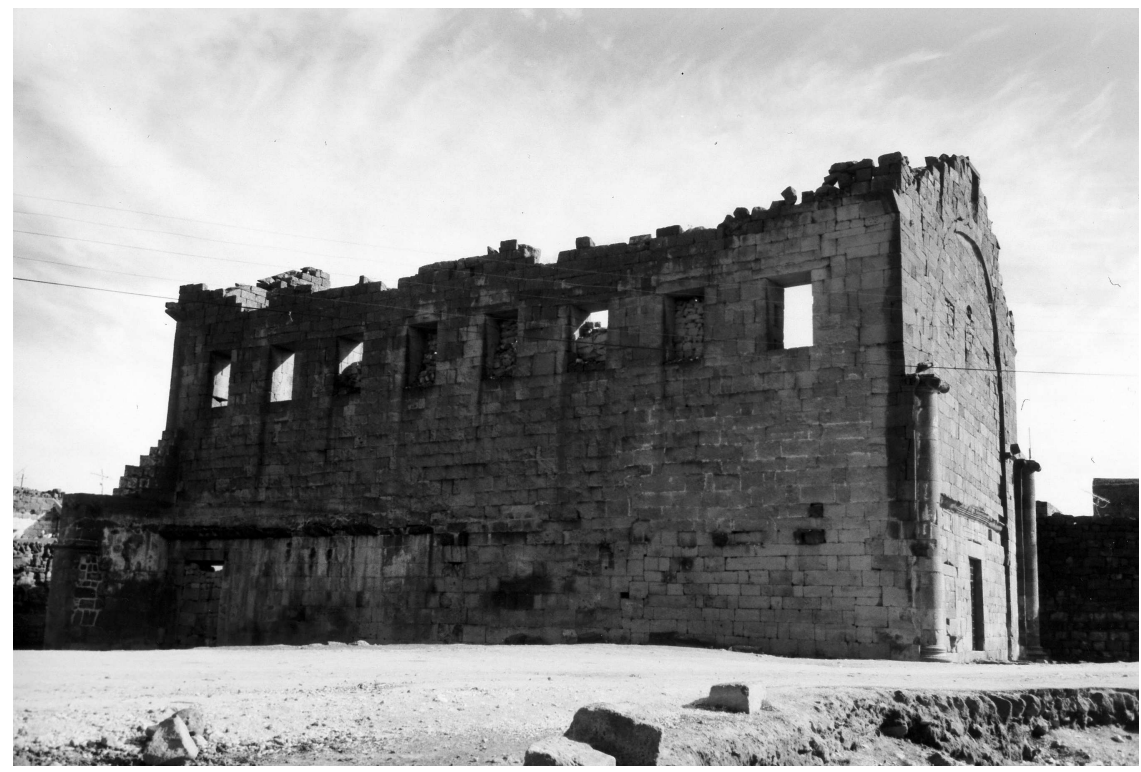

Figure 4.1 Ruins of the church in Bosra (the author's private collection). 
and philosophy were cultivated alongside theology. It can be said that even "dynasties" of Christian doctors and scientists emerged (Allard 1962: 375-388; Fiey 1980). Christians had always played an important role in the Muslim administration. At the courts of the caliphs, they were secretaries - which corresponded to today's ministerial function (Massignon 1942: 7-14; Cheikho 1987) - court doctors and regional administrators. During the reign of the first Abbāsid rulers, the "Nestorian" patriarch was an important figure in Baghdad, and the Church which he headed spread extensively throughout Central Asia, including China (Vine 1937: 130-135).

Yūsuf Nașrallāh (1911-1993) argued with the claim that the Abbāsids were generally tolerant of Christians (Nasrallah, Haddad 1979: 4-5). In fact, the situation was more complex, as periods of relative tolerance intertwined with more or less severe repression. On the other hand, Christians and Jews worked in the Abbāsid administration, sometimes holding high positions, even viziers [wuzarā] or secretaries [kuttāb] (Sirry 2011: 187-204).

The tolerance was opportunistic and inconsistent, especially with regard to the Melkites. Long before the government of alMutawakkil, infamous for persecuting Christians, they experienced a humiliation shortly after 750 . Theophanes (Theophanes 1885: 211) and Dionysius of Tell-Mahrē (Dionysius of Tel-Mahree 1993: XXVIII) report a whole litany of anti-Christian regulations by Caliph Abū Ğa far 'Abd Allāh b. Muḥammad b. 'Alī al-Manșūr (754-775). In 756, he forbade Christians to build new churches, display the sign of the cross in public or discuss religious matters with Muslims. In 757, he levied taxes on monks, even on solitary hermits, and confiscated valuable liturgical vessels for the treasury. In 766, crosses were knocked down from churches, liturgy at night was forbidden and the Arabic language was imposed. Christians and Jews were also forced to wear distinguishing signs. For various reasons, the hierarchs of three churches were imprisoned: the patriarch of Melkite of Antioch, Theodoretus (before 787-[?] or 781-812[?]), the "Jacobite" patriarch George I of Antioch (758-790- he spent nine years in prison, from 768-777), and the Patriarch of the Church of the East ("Nestorian") Ya'qob II (753-773). Anti-Christian fiscal laws were not lifted after al-Manșūr's death (Putman 1975: 130; Grumel 1958: 449; Pargoire 1971: 227-278).

The administrative system of the family of Barmakid officials (750-803) soon became a state within the state, contributing to the "Iranization" of the Arab Islamic Caliphate. At the Abbāsid court, they had an overwhelming influence on state policy, while also being patrons of science and art (Kennedy 1990: 89-98). The Barmakids were tolerant of Christians; for example, they defended the followers of Christ from Edessa who were falsely accused of

Persecution of the Christians of alManșūr, 754-775
Christians in the politics of the Barmakids and Hārūna ar-Rašĩd 
Persecution of Christians under Caliph Abū l-'Abbās 'Abd Allāh alMa'mūn (813-833)

Apogee of the Abbāsid persecution of Christians under Al-Mutawakil (847-861) treason (Michael le Syrien 1905: 3: 10). Caliph Hārūn ar-Rašīd, concerned about the influence of the Barmakids, brutally removed them from power $(30,676,000$ dinars in cash and all their proprieties were confiscated). Hārūn ar-Rašīd was influenced by the supreme Kadi of the Abū Yūsuf Hanafi school (died 798), who advised the caliph to take a sharp course towards Christians (Abū Yūsuf Ya 'qūb 1932: 72-73). It seems that with the accession to the throne of Hārūn ar-Rašĩd (786-809), the situation of Christians was unclear and unstable. In the negotiations of Charlemagne (748-814) with the caliph in 797, the problem of the status of Christians (Einhard 1911: Vita Karoli Magni Holder-Egger: 11-25) was raised, as information about their plight had reached the West as well (Karalevskij 1924: 599). Einhard (c. 775-840), the biographer of Charlemagne, characterized the emperor as a person who "was very forward in succouring the poor, and in that gratuitous generosity which the Greeks call alms, so much so that he not only made a point of giving in his own country and his own kingdom, but when he discovered that there were Christians living in poverty in Syria, Egypt and Africa, at Jerusalem, Alexandria and Carthage, he had compassion on their wants, and used to send money over the seas to them" (Einhard 1911: Vita Karoli Magni: 19; English translation: The Life of Charlemagne, Einhard 1880: XVIII: 27).

It happened just as Abū Yūsuf advised. With the ascension to the throne of Caliph Abū al- 'Abbās 'Abd Allāh al-Ma'mūn (813-833), there was another escalation of hatred for Christ's followers on the part of the authorities. The scheduled persecution of Christians in Syria and Palestine occurred in 814. It was so severe that many Christians from different Churches left the Middle East, taking refuge in Cyprus and other territories under Byzantine rule (Dīk 1999; Sourdel 1959: 180; 1961: 31-32; Putman 1975: 135-145). Moreover, the aforementioned Dionysius of Tel-Mahrē (Dionysius of TelMahrē 1993: XXVIII) left us a whole list of the wrongs that were done to Christians during the reign of the next caliph, Abu Ğa far Hārūn b. al-Mu'tașim al-Wātiq (842-847).

The situation of the Christians became even more difficult under the reign of Al-Mutawakkil (Allard 1962: 382; Nasrallah, Haddad 1979: 6). al-Ṭabarī (839-923), Ibn al-Ațīr (1160-1233), al-Maqrīzī (1364-1442), and Ibn Haldūn (1332-1406) vividly describe the deteriorating status of the "People of the Book" and the anti-Christian regulations of this era (for more on this topic, see Fattal 1958: 101-102). Al-Mutawakkil's reign was marked by the restoration of strict orthodoxy and extreme religious intolerance (he released from prison the famous, literalism-orientated jurist Ahmad b. Hanbal [780-855]). The caliph, who took the title of "The Shadow of God on Earth," spoke out in favour of overwhelmingly reactionary 
legislation devised by Muslim lawyers and theologians. Christians, Jews, and Shi'ites were severely persecuted. Some churches in Baghdad were demolished at the behest of the ruler. In 853, the caliph forbade Christian children to attend Muslim schools or any Muslim to teach them, which the 12th-century "Nestorian" historian Mārī b. Sulāymān clearly reported in his Kitāb al-Miğdal: wa lā tu'allam awlāduhum fì makātib al- 'arab!: "[Christian] children should not go to Arab schools!” (Mārī b. Sulāymān 1899: 2: 79). AlMutawakkil even recommended that Christians hang wooden images of demons on their homes (Fiey 1993: 972). In 859, the process of Islamizing Armenian and Georgian aristocrats began after they rebelled against the 'Abbāsid rule (Ter-Ghewondyan 1976: 20-25). In an atmosphere of fierce Muslim-Byzantine wars in the 9th and 10th centuries, the Melkites were seen as potential traitors or collaborators with Constantinople (Canard 1973; 1974).

Between 868 and 905, Egypt, Syria, and Palestine were ruled by the Tulunids, descendants of the rebellious Ahmad b. Țūlūn (868-884), who annexed Syria and Palestine (i.e. the territories of the three ancient Melkite patriarchates) to Egypt. The Tulunids went down in history not only as great reformers and builders (Randa 1992), but also tolerant rulers. Christians during this period received more liberties than under the previous rule (Nasrallah, Haddad 1979: 6).

After Baghdad took over the lands of the Tulunid state (905-969), some laws that were unfavourable to Christians returned. However, typical of the Abbāsids, the double standard of treatment of Christians was continued. In 908, the vizier, Ibn al-Furāt, abolished the law of inheritance for Christians (Massignon 1963: 254). On the other hand, this kind of legal regulation were not applied, because putting them into practice depended primarily on local administrators and officials. At that time, Christian officials sometimes had real power and supported their fellow believers (Putman 1975: 92-126). Besides, there were many examples of noble and just people among the Muslims who supported Christians. The Turkic historian and a court companion of three Abbāsid caliphs, Abū Bakr Muḥammad b. Yahyāa b. al-'Abbās al-Ṣūlī (died 946), wrote that a certain Abū al-Hasan Sa 'īd b. 'Amr b. Sanğala (10th century), a secretary of Caliph al-Rāḍi (934-940) and controller of treasury expenses, had done a lot to help Christians. For example, on 7 December 937, he managed to get punishment from the caliph himself for a certain Muslim who hurt the family of a Christian official, Abū 'Amr b. Šurayh (Șūīi 1946: 54, 107, 142-143, 153, 159-160, 189, 216, 227-228, 230; 1950: 18, 27, 117).

At the beginning of the 10th century, there was a break with certain unwritten customs that ascribed certain jobs to Christians. For example, even in the 9th century, according to the information of al-Ğăhiz (Ğāhiz 1900: 110), there was a conviction among Muslims about the

Christians during the early decentralization of the Abbāsids
Christian-Muslim scientific contacts 
greater effectiveness of Christian doctors; the situation had changed by the 10th century. Along with most Christian physicians, there were Muslims, such as Bakr Muḥammad b. Zakarīyā ar-Rāzī (854-925), who worked in Baghdad (Ullmann 1970: 128-136; Sezgin 1970: 274-294). What happened in medicine was also happening in the field of philosophy and literature. The exchange of knowledge between Christians and Muslims became natural. For example, Muhammad b. Tarhān abu Nasr al-Fārabī (c. 872-950) had three Christian masters from whom he learnt philosophy: first Ibrāhīm al-Marwazī (10th century), then a Nestorian Christian monk Yūhannā b. Haylān (10th century) and finally Abū Bišr Mattā b. Yūnus ([870-940] Samir 1982: 18-19). On the other hand, al-Fārabī himself was a master for a Christian philosopher named Yahyā b. 'Adī (893-974), whose school educted as many as 10 important philosophers. Of these, six were Muslim and four were Christian. This proportion is most likely representative of the intellectual situation of the 10th century. In turn, one of Yahya b. 'Adī's students, a Christian, Ibn al-Hammār (943-1020), had three famous disciples: a Persian Muslim, 'Alī b. alHusayn b. Hindū (died 1018); a Christian, Abū Sahl 'Isā b. Yahyā alMasīhī (970-1010); and a Christian priest, Abū al-Farăg 'Abdallāh b. al-Ṭayyib (died 1043). Abū Sahl 'Isā b. Yahyāa al-Masīịī was the master of Abū Alī Husayn b. 'Abdallāh b. Sīnā, or the great Avicenna (980-1037). Also, Abū l-Farăg 'Abdallāh b. al-Ṭayyib gathered a large number of disciples, many of whom were Muslims (Samir 1980: 31-34; 1982: 18-19; 1989: 285; Allard 1962: 375-388).

The links between Christians and Muslims became part of the scientific landscape of this era. There are many examples of "genealogy (schools)," be they Muslim or Christian scholars, which indicate an atmosphere of freedom and tolerance of research in scientific circles. Of course, there were fundamental differences in theological science between Christians and Muslims (Griffith 1999a: 24 44; Canard 1962: 267-287).

Extent of Islamization Islam in the Middle East was gaining new followers, mainly in the Christian milieu. From the 8th century on, the number of Christians declined steadily. The question of when Islam became the majority religion of the population of the mediaeval Middle East has long fascinated researchers. They postulate an "age of conversion" in which the majority of the Middle Eastern population converted to Islam relatively quickly. The later "era of conversion" in the Middle East is generally accepted as well - with the exception of Egypt, where the process happened earlier. Research findings depend on the interpretation of the sources that indicate structures and cultural dynamics of agrarian societies. Some scholars propose that this process should be considered more closely with structures and cultural dynamics in agrarian societies (Carlson 2018). In turn, Richard Bulliet suggests a method of the 
analysis of the genealogy of Muslim notables, which links it with political and institutional history (Bulliet 1979). Certainly, these analyses are helpful, but it is debatable whether the intensification of Islamization always coincided with the weakening of the centralized government.

At any rate, it seems that the process of Islamization intensified after the persecution of al-Mutawakkil (Fiey 1980: 85-90). It is difficult to establish precisely the proportions of Christians to Muslims in the 10th century. The researchers of this problem provide indicative statistics and estimates. In the 9th century, Christians likely constituted the majority (at least in large swaths of the Middle East), but in the 10th century no more than $20 \%$ were Christian. Thus, the initial reigning Muslim minority became a certain majority after about 300 years (Samir 1989: 287).

\subsection{The Melkite communities in a new crucible of interaction}

Although the Melkite patriarchs of Antioch, Alexandria, and Jerusalem had been in the lands of Islam for almost two centuries, they were somewhat involved in the life of the entire Church. The iconoclastic crisis or the Photios case was clear proof of this. Obviously, on a local level, the Melkite Churches had a whole range of problems of their own, the solution of which was their own task.

\subsubsection{The patriarchate of Antioch}

From 750 to the Byzantines regaining Antioch, there were 12 or 13 patriarchs on the Melkite patriarchal throne. The chronology of their episcopal ministries is as follows (Boudier 2018: 45-80; Grumel 1958: 446-448; Karalevskij 1924: 697-700):

List of the Melkite patriarchs of Antioch, 750-969, and their tragic fates

$\begin{array}{ll}\text { Theodore I of Antioch } & 750 / 751-773 / 774 \\ \text { Theodoretus } & \text { before } 787-(?) \text { or } 781-812(?) \\ \text { Job } & 813 / 814-844 / 845 \\ \text { Nicolas I } & 847-867 \text { or } 846-868(?) \\ \text { Stephen IV (?) } & 870 \text { (one day pontificate [?]) } \\ \text { Theodosius I } & 870-890 \\ \text { Simeon I } & 890-907 \\ \text { Elias I } & 907-934 \\ \text { Theodosius II } & 936-943 \\ \text { Theocharistus } & 944-948 \\ \text { Agapius I } & \text { Agapius b. Qa barūn (953-959?) or (?)-(?) } \\ \text { Christopher } & (960-967) \\ \text { Eustratius } & (969)\end{array}$


Some scholars (Grumel 1958: 447) do not include Patriarch Agapius I in the lists of patriarchs of Antioch, as there are only a few mentions of his existence (Nasrallah 1976b: 60).

The Melkite patriarchs of Antioch of this period were evidently tragic figures. The beginning of the reign of Caliph Abū al-'Abbās alSafāh in 750 coincided with Antioch Theodore I's elevation to the patriarchal throne. However, Theodore I of Antioch (750/751-773/ 774) was soon imprisoned in Baghdad by Caliph al-Manșūr (around 758 , more or less at the same time, the patriarch of Antioch, and head of the Syriac Orthodox Church ["Jacobite"] George I [758-790] and the Patriarch of the Church of the East ["Nestorian"] Ya'qob II [753-773] were also punished). His successor Theodoretus (before 787-[?] or 781-812 [?]) was suspected of conspiring with the Byzantines and exiled to Moab in 787. Another patriarch, Job (813/ 814-844/845), was forced by the Muslim authorities to crown the usurper Thomas, who rebelled in 821 against the Byzantine emperor Michael II the Amorian (820-829). Thomas took refuge in the caliphate and fought against the Byzantines alongside the Muslim troops. Job was finally excommunicated by the Greek bishops, and the usurper himself fell into Byzantine hands two years later. Anyway, Job was a tragic figure. Forced by Caliph al-Mu tașim (833-842), he had to accompany Muslim army during the siege of Amorion in 838. There, he was stoned to death by the inhabitants, after commanding them to submit to the caliph (Theophanes continuatus PG vol. 109: 68; Michael le Syrien 1905: 3: 75; Ioannes Antiochenus 1864: 1117-1148; Troupeau 1999: 329; Vasiliev 1932: 361-363; Vasiliev, Honigmann 1935: 22-49). In turn, Elias I was sent by Caliph Abū al-Faḍl al-Muqtadir (908-929/932) to Constantinople to negotiate the release of Muslim prisoners of war with the Byzantines. This gesture of the patriarch did not stop the Muslims from destroying the Cathedral of Our Lady in Damascus in 924. The tragedy did not spare Christopher (960-967), who supported the Hamdanid prince Abū 1-Hasan 'Alī b. Abī 1-Haiğà' Saif ad-Daula at-Taglibi (916-967) during the revolt in 965, despite the fact that the latter undertook numerous wars against Byzantium. In 967, the patriarch was murdered by a former rebel (Eutychius 1909: 60; Karalevskij 1924: 601-602; Troupeau 1999: 329).

Opposition against Islamization and new martyrs
In 779, during the reign of Caliph al-Mahdī (775-785), the Melkite Church in Aleppo was looted and demolished. Michael the Syrian included in his chronicle a valuable reference to the Christian Arabs of Banū Tanūh, who lived in tents in and around Aleppo. It is hard to say whether they were Melkites or "Jacobites." Tanūh, that is 5,000 men, not counting women and children, were forced to convert to Islam. Finally, in 779 , as a wealthy clan, Tanūh was considered a rival and destroyed in 813 by the people of Aleppo, which had grown into 
a vast city. Ultimately, the Tanūh were defeated by the Banu Qais and left for Qinnasrin, after abandoning their homes and great camps full of wealth (Michael le Syrien 1905: 3: 3; Morony 2010: 158).

Finding the relics of the head of St John the Baptist at the Grotto Monastery near Homs and transferring them to a large church in the city was an occasion to celebrate for the Melkites. The solemn celebration of this event in the wake of the defeat inflicted by the Byzantines on the caliph's army upset Caliph al-Mahdī (775-785) so much that he sent Muslim groups to Homs with orders to force the apostasy of the Christians there. This turned into open persecution of Melkites, during which many suffered martyrdom. Similar incidents took place in Damascus, where Muslims were destroying churches (Theophanes 1885: 285-300; Putman 1975: 130-134; Haddad 1985: 29; Karalevskij 1924: 599).

The Synod of Hiereia, conceived as a council, gathered 338 bishops according to the organizers. However, the most important figures, the pope and the Melkite patriarchs, did not participate. Therefore, despite its aspirations to universality, it was never recognized as such. Moreover, the teachings of this synod reached us through the texts of the Second Council of Nicaea (Concilium Nicaenum II 1767c: 336-364).

The Synod of Hiereia confirmed clearly that the Imperial Church was confined to Greece and Anatolia and was by no means a representative of Rome and the Melkite patriarchates. According to some authors, the iconoclastic crisis revealed a peculiar connection between the Eastern patriarchates and the pope, which was confirmed by a Melkite synod around 767.

Recently, there has been a discussion about the meaning of the Melkite synod in 767, which condemned iconoclasm, that is, assembly of the bishops of the East between Hiereia (754) and Nicaea (787). The Latin sources strongly confirm the existence in 767 of a synodical letter under the name of Patriarch Theodore I of Jerusalem (745 [752?]-770). For some authors, this is the evidence of a connection between the Eastern patriarchates and the papacy, but such interpretations are debatable. The existence of this synod is first derived from the letter from 767 of Pope Constantine II (in fact an antipope whose short and dramatic reign lasted from 5 July 767 to 6 August 768) to King Pepin the Short (751-768). It follows from the antipope's letter that the predecessor of Constantine II, Pope Paul I (757-767) received a synodica fidei (synodal letter) from Theodore I, the patriarch of Jerusalem. Theodore I of Jerusalem confirmed that he and the patriarchs of Antioch and Alexandria (names not given) and many other bishops declared their acceptance of the cult of holy images (Epistolae Merowingici et Karolini aevi 1892: 1/3: 652-653). The Greek text has also been preserved in the acts of the Council of Nicaea in 787

The anti-iconoclastic front: the pope and the Melkite patriarchsthe end of the first phase of iconoclasm in 787 
(Concilium Nicaenum II 1766: 1135-1136). Moreover, Pope Hadrian I (772-795) also quoted the synodal letter from Theodore I of Jerusalem, in a letter to Charlemagne (768-814) around 791-794. The letter informed the ruler of the results of the Second Council of Nicaea and mentioned the three Melkite patriarchs: Theodorus I of Jerusalem (745 [752?]-770), Cosmas I of Alexandria (727 [731?] or 742-768), and Theodorus I of Antioch who ruled 750/751-773/774 (Epistolae 1899: 3: 11). In principle, the authenticity of Theodore's letter is discussed. Some scholars consider the passage about the Roman primacy in Pope Hadrian's version to be an interpolation of the papal chancellery (Auzépy 1999: 219-220). Not all researchers of this problem, however, agree with the thesis about the "jurisdictional forgery" of the papal chancellery. Paradoxically, during this period, there were interdependencies between the pope and the Melkite patriarchs generated by the attempts of Constantine V Kopronymos to interfere with the jurisdiction of the Eastern patriarchates. Thus, the reference to the Roman primacy in Theodore's letter could even be authentic, as it was an attempt to defend the independence of the Melkite patriarchates from Constantinople by appealing to the authority of distant Rome (Codoñer 2013: 155). Expounding on the interpretation of Juan Signes Codoñer, it can be added that although the doctrinal question was undoubtedly the root of the iconoclastic crisis, it should also be seen as a revival of the Byzantine political philosophy, which sought to subordinate the Church to the emperor. This goal can be seen in the letter of Emperor Leo III to Pope Gregory II (715-731): "I am emperor and priest" (Gregorius II 1766: 975). Many bishops condemned this claim of the Byzantine rulers. Moreover, in accordance with practice before the Eastern schism in 1054, if the bishop of Rome was not represented at a synod of bishops, it was by no means binding for the whole Church (Gouillard 1976: 25-54). This was clearly expressed even by Patriarch Nikephoros I of Constantinople (806-815): "Without whom [the Romans presiding in the seventh Council] a doctrine brought forward in the Church could not, even though confirmed by canonical decrees and by ecclesiastical usage, ever obtain full approval or currency. For it is they [the popes of Rome] who have had assigned to them the rule in sacred things, and who have received into their hands the dignity of headship among the Apostles" (Nicephorus 1863: 597; Schatz 2004: 94). This also explains the exceptional appeals of the Melkite patriarchs to the papacy. These relations seem to have continued in the 9th century as Leo V the Armenian (755-820), immediately after taking the throne (813), ordered a second iconoclasm, stricter than the previous one, which lasted for 30 years (up to 843).

"Little schism" inside the patriarchate of Antioch
After the death of the aforementioned Patriarch Job (813/814-844/ 845), two factions opposed each other pretending to appoint the patriarch of Antioch. The first party supported the metropolitan of 
Damascus, Nicolas (later Patriarch Nicolas I 847-867 or 846-868[?]), and the second group supported Eustachius (he was not even ordained a priest), associate of Basil, metropolitan of Tyre. Eustachius planned to receive the office with the support of the emir of Antioch, but despite his efforts, Nicolas, who initially resided in Aleppo, was elected patriarch. The Melkite patriarchate of Antioch became the arena of battles between the two parties. The emir of Syria, Abu Sa $\overline{1}$ d, took money from the two opposing groups in return for the support which he alternately gave to both conflicted parties. As a consequence of the prolonged conflict among the Melkites, the Churches in Antioch were split. The hierarchy was also split in Calcicos (today's Ar-Raqqa). Fortunately, this "little schism" died out with the death of the feuding hierarchs. However, in the face of the many difficulties with which the Melkites dealt in Syria, this dispute led to a further weakening of the Melkite Church, even more so since the emir became the arbiter (Michael le Syrien 1905: 3: $97-100)$.

The problem of the "little schism" in Antioch extended further. Eustachius, as an opponent of Nicolas I, the patriarch of Antioch, became a supporter of Photios I of Constantinople (858-867 and 877-886). Nicolas, however, avoided involving his patriarchy directly in Photios' dispute with the papacy. Leaving aside the complicated course of the Phocian dispute and the personality and role of Photios himself, it is worth mentioning his Encyclical to the Christian Capitals of the East from 866 (Encyclical 2020). Nicolas I, the Melkite patriarch of Antioch, was elected after a two-year vacancy of the capital, in the sixth year of the reign of Caliph Abū Ğa far Hārūn b. alMu'tașim, or al-Wātiq (842-847), so in 847 (Eutychius 1909: 62). In turn, Photios made his claims to take over the patriarchal power on 23 December 857. At the first synod organized by him in 861, no representative of the Melkite patriarchates appeared, despite the fact that in 860 Photios had sent a letter announcing his enthronement to the patriarchs of the East. The acts of this synod, signed by papal legates and 130 bishops, were destroyed by a decision of the "antiPhotios" council in 869. All information on this subject comes from the reports of the legates after their return to Rome (Dagron 1999b: 149). Most likely, Eustachius, a follower of Photios from the patriarchate of Antioch, died before 861 (Karalevskij 1924: 600; Hefele 1911: 4: 75).

The famous encyclical of Photios I of Constantinople (858-867 and $877-886)$ to the Melkite patriarchates from 866 indicates the degree of hostility that then divided Rome and Constantinople. The document contains a whole barrage of accusations against Latin people. In it, Photios appears as a defender of "pure credo" and "unadulterated faith," when sharply criticizing the "false doctrines" of Latin

Antioch and the activities of Photios 
missionaries in Bulgaria who joined the Filique (Encyclical 2020: 866). The Eastern patriarchates, however, maintained a moderate attitude in the dispute between Rome and Byzantium, deeming that the revision of the trial of St Ignatios of Constantinople (patriarch [847-858; 867-877], who was removed in 858 by Bardas, the regent for emperor [855-866]) was an internal affair of the Constantinople Church. Most likely, the cautious attitude represented in the Photian doctrinal dispute by the eastern patriarchates resulted from the difficulty of properly assessing the situation. However, in the famous Photian synod in the second half of 867, which excommunicated Pope Nicolas I the Great (858-867) and rejected his claims of primacy, three representatives of the Melkite patriarchates (probably monks appointed by Photios himself) took part (Les regestes 1989: no 498; Le Liber Pontificalis 1892: 2: 178-179; Hefele 1911: 4: 447). The vicissitudes and volatility of Rome's relationship with Constantinople put the Melkite patriarchs in a very awkward position. The Council of Constantinople excommunicated Pope Nicolas I in 867 and declared him anathema for his claims to primacy, his contact with Bulgaria and the "Filioque" formula. However, two years later, there was another council in Constantinople, held in 869-870. It abolished the decisions of the one from 867. After almost 10 years, in 879, another one was called in Constantinople, which restored the conclusions of the council of 867. The Roman Catholic Church to this day has rejected the councils of 867 and 879-880, but accepted the council of 869-870; the opposite is the case with the Orthodox churches. These events began to move the Melkites more and more away from a neutral position towards supporting the claims of Constantinople (Theodosius patriarchal Antiochiae 1772: 443-450).

Melkites in the circle of Tulunid and Byzantine dependencies
From 868 to 905 , all three Melkite patriarchates entered the sphere of influence of the Tulunids. The birth of a new Muslim state took place, though in an atmosphere of conflict with the Abbasid caliphate. No wonder that the clever Ahmad b. Tülūn needed a peaceful relationship with the Byzantine Empire. Therefore, he allowed Melkite Bishop Thomas, metropolitan of Tyre (who was also the administrator of Antioch during the vacancy in 867-870) to go to the council in Constantinople under the pretext of negotiating the return of Muslim prisoners to Syria. Sources say that Thomas of Tyre delivered his speeches at the council through the priest Elias, the representative of the Melkite parish priest of Jerusalem, because the representative of Antioch had difficulty speaking Greek. Both the representatives of Antioch and Jerusalem stated that the Melkite Churches never recognized Photios (Hefele 1911: 4: 487-489; Dagron 1999b: 155).

Thomas of Tyre stayed briefly in Constantinople, not wanting to arouse Muslims' suspicions. Moreover, he was urged to choose a 
patriarch, who was acutely needed in Antioch. According to the historian Eutychius, the election of the Antiochian patriarch took place in the first year of the reign of Abū al-'Abbās Aḥmad alMu'tamid (870-892), that is, in 870 (Eutychius 1909: 69). Then the patriarch Stephen IV (870) was elected, but he died on the day of consecration. The new head of the Antioch Church, Theodosius I, who led the Melkite community for 20 years (870-890), was quickly elected.

Between 890 and 891, another intriguing conflict took place in the territory of the patriarchate of Antioch. It was quite an emotional dispute between the newly elected patriarch Simeon I (890-907) and David, metropolitan bishop of Damascus. Analysing this conflict in her detailed research, Mathilde Boudier showed many interesting details of the life of the Melkites in the Tulunid era (Boudier 2018: 45-80). The conflict began during Patriarch Simeon's visit to Damascus. Generally speaking, the patriarch did not accept David. He supported the opposition against David, tried to control economic matters and intervened in the local Melkite hierarchy. For example, Simeon not only absolved two deacons who had been suspended or excommunicated by David, but also ordained one of them as the metropolitan bishop of Mambiğ, Hierapolis. Simeon I went so far as to draw up an indictment before the Muslim authorities. David of Damascus brought a complaint against Patriarch Simeon I to Patriarchs Elijas III of Jerusalem (878-907) and Michael II of Alexandria (870-903). They supported David's claims, but Simeon I continued to control the Damascus Church. Michael II of Alexandria, and then Elias III of Jerusalem, recalled the stubbornness of Simeon in their letters and urged him to reconcile with David (Boudier 2018: 50-60). Simeon I of Antioch, facing two patriarchs and some of the people of Damascus, decided to convene a synod. We have no information on how the synod (or synods) was called, and the outcome is unknown.

The dispute showed the problems of the Melkite hierarchy, the legal opinions of both patriarchs and the letter of the inhabitants of Antioch (ahl Anțākiya). The conflict also involved secular Christians and Muslims in Damascus who were in charge of administering church income and property, including a bakery (furn al-kanisa). In fact, the conflict between David and Simeon I of Antioch was just one episode in a decades-long struggle between different parties over control of church property in Damascus (Boudier 2018: 45, 65-80).

Appeals to the Melkite patriarchs also took place in other cases. During the reign of Emperor Leo VI the Philosopher (886-912), the Church's spiritual authority was highly valued, and the Church was also subordinated to secular authority. Leo VI fully identified with Antioch and the problem of the fourth marriage of Emperor Leo VI Christianity and, in his own opinion, undertook many initiatives that 
were to add splendour to the Church. This emperor wrote and delivered homilies and compiled the Novella collection, in which he identified the points of inconsistency between imperial and ecclesiastical laws, giving priority almost every time to the canons of the Church (Léon VI 1944: Les novelles de Léon VI: 4-9). He was convinced that he reflected a supernatural hierarchy in the organization of power (Oikonomides 1972: 80-85).

This ruler, so devoted to Christianity, however, became embroiled in a marriage "scandal" that severely condemned the Byzantine Church. The Eastern tradition tolerates second marriages, but the canons treated third marriages as polygamy, or even prostitution. Leo VI himself banned third marriages in his Novella collection. Unfortunately, he himself broke this law because his marital life turned out to be extremely unfavourable. His first wife, Theophano Martinakia (886-893) in 893 retired to a monastery in the Blachernae suburb of Constantinople, where she died around 896/897. Their child also did not survive. Soon he married Zoe Zaoutzaina (898-899), who, like his first wife, died quickly (899), leaving no male heir to the throne. Against the canons of his Novella, Leo VI asked for a dispensation so that he could marry Eudoxia Baiana (900-901); he received it. Unfortunately, the third wife of the emperor did not live long either; she and her son died in 901 shortly after the birth of the child. The 40-year-old emperor faced the collapse of his dynasty. When his lover, Zoe Karbonopsina (906-920), bore him a son, the future ruler Constantine VII Flavius Porphyrogenitus (913-959), it was necessary to legitimize his birth. The fourth marriage of Leo VI put the emperor in conflict with the patriarch of Constantinople, Nicolas I Mystikos (901-907; 912-915). Although Leo VI took the position of a penitent, respecting the authority of the bishops in the matter of marriage, he still insisted on recognizing his son as the rightful heir. In the dispute with the bishops of the patriarchate of Constantinople, the emperor resorted to the help of the pope and the Melkite patriarchs of Antioch, Jerusalem, and Alexandria, who were more understanding in such matters (Dagron 1999b: 164). As was the case before, not the patriarchs themselves, but their representatives came to Constantinople. As for Antioch, after the death of Theodosius I (890) and a short vacancy in the patriarchal seat, was elected Simeon b. Zarnāq or Simeon I (892-907) in the first year of the regency Abū Ahmad Țalha b. Ğa far al-Muwaffaq (870-891), the Abbasid prince and military leader, who was de facto ruler of the Abbasid Caliphate (Eutychius 1909: 73). Pope Sergius III (904-911), in response to the appeal of the Byzantine emperor, laid down in writing the traditional teaching of the Western Church, which did not limit the number of consecutive marriages considered valid. Consequently, the patriarch of Constantinople, Nicolas I Mystikos, 
was removed from office, and his successor Euthymius I of Constantinople (907-912) acted in the spirit of the emperor's policy. The participation of the Melkites in the settlement of this dispute was minor, although the arrival of representatives of the eastern patriarchs in 907 supported position of Leo VI. However, it must be honestly admitted that the new patriarch, Euthymius, forced the emperor to legally confirm the prohibition on third and fourth marriages and granted him a partial dispensation in return, on the condition that he would make public penitence. Nicolas I Mystikos, removed from office, was soon restored to the patriarchal throne (912). Leo VI provided the hagiographers with an example of an orthodox ruler who respected the clergy and, in order to pass power down to his son, had to confess his bodily sin and publicly perform penance (Dagron 1999b: 165).

Another phase of the wars between Arabs and Byzantines caused a new wave of persecution of Christians under Muslim rule, which particularly affected the Melkites. In October 924, Muslims from Damascus sacked and destroyed the Melkite Church of the Blessed

Melkites in the 10th century before the Byzantine recapture of Antioch Virgin Mary and looted the monastery near the church (Eutychius 1909: 83). The Melkite patriarch of Antioch, Elijas I died in 934. In Ramadan 323 in the Hijra, that is August 935, he was succeeded by Theodosius II (936-943; Grumel 1958: 447 gives 936 as the date of

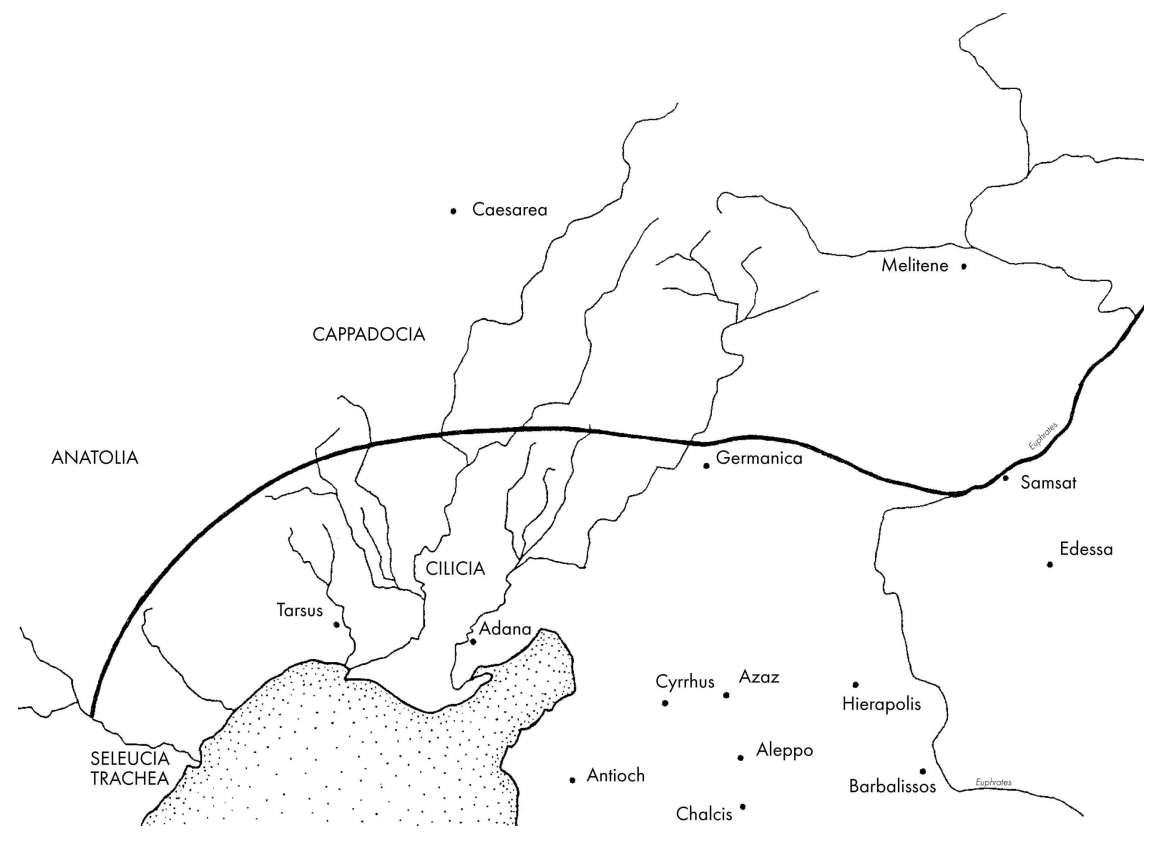

Map 4.1 Byzantine-Arab border around 960 . 
accession). At the end of 937, the patriarch of Constantinople, Theophylact Lekapenos (933-956), asked Melkite patriarchs to mention his name in solemn liturgical prayers, which had been forbidden in the lands of Islam since the Umayyad times. The Melkite patriarchs agreed to this request (Eutychius 1909: 93). One of the primary sources of information about the 10th-century patriarchs is the chronicle of Yahyā b. Sa'i $\bar{d}$ (11th century), who belonged to the Melkite Church and was a continuator of the Eutychius Annals. According to Yahya, Theodosius II headed the patriarchate of Antioch for seven years. Although the author was very critical, he did not avoid certain inaccuracies. Elsewhere, he writes that Theodosius II died shortly after the Byzantines conquered Rās al-'Aīn, that is, at the end of 943 . Another parish priest was Theocharistus (944-948), about whom we have very little information. After Theocharistus's four-year reign, there was a relatively long, 12-year vacancy in the episcopal see of Antioch, which appears to have been the result of the Arab-Byzantine wars. Christians - as has already been mentioned-paid the price in the form of Muslim persecution for the successive victories of the Byzantines over Arab troops. During the reign of Caliph al-Muți (946-974), that is, in 960, in an atmosphere of political turmoil, Patriarch Christopher (960-967) was elected. He was the loyal bishop to Hamdanid prince Sayf ad-Dawla (944-967), the founder of the Emirate of Aleppo. During the riots that took place in 965 as opposition to the Hamdanidian rule, the patriarch left Antioch and took refuge in the convent of Simeon Stylites. This hierarch strove for peace, opting for the necessary compromises. This attitude earned him the hatred of the Muslim opponents of Sayf adDawla. On 29 October 969, the Byzantines recaptured Antioch. One of the Muslim leaders, on meeting Christopher, pierced him with a spear (Eutychius 1909: 116; Karalevskij 1924: 602; Schlumberger 1890: 723). Antioch remained in the hands of the Byzantines for nearly 120 more years.

List of Melkite patriarchs of Alexandria, 750-969

\subsubsection{The patriarchate of Alexandria}

Information on the situation of the Melkite Church in the patriarchate of Alexandria in the period of 750-969 is very limited. Indeed, we can point to a few facts without many interesting details. This is because the Melkites in Egypt were an increasingly marginal minority.

On the basis of relatively laconic source references, the following chronology of the Melkite patriarchs of Alexandria between 750 and 969 can be reconstructed (Grumel 1958: 442-444; Maséro 1923: 361-379): 


\begin{tabular}{ll}
\hline Cosmas I & 727 [731?] or $742-768$ \\
Politianos & $768-813$ \\
Eustatius & $813-817$ \\
Christopher & $817-841(848 ?)$ \\
Sophronius I & $841-860(848-860 ?)$ \\
Michael I & $860-870$ \\
Michael II & $870-903$ \\
Sede vacante & $903-907$ \\
Christodulos & $907-932$ \\
Eutychius & $933-940$ \\
Sophronius II & 941 \\
Isaac & $941-954$ \\
Job & $954-960$ \\
sede vacante & $960-963$ \\
Elias I & $963-1000$ \\
\hline
\end{tabular}

The Abbasid seizures of power (750) fell on the pontificate of Cosmas I, who, as already mentioned, was the first resident Melkite patriarch in Alexandria after the Muslim conquest of Egypt. In 742-743 he renounced Monotheletism, a popular doctrine among the Alexandrian Melkites, since it was promulgated by Emperor Heraclius. Apart from the exceptions, for example, of Patriarch Eutychius, we do not have much biographical information about most of the patriarchs of this period.

The iconoclastic crisis was not a significant problem of this reduced patriarchate. Constantine V Kopronymos (741-775) did not invite the patriarch of Alexandria to the Council of Constantinople in 754. However, as already mentioned, over 10 years later, Cosmas I of Alexandria (727 [731?] or 742-768), along with the other Melkite patriarchs, condemned iconoclasm. Likewise, at the Second Council of Nicaea (787) monk Thomas represented Politianos (768-813), the Melkite patriarch of Alexandria, against the iconoclasts (Concilium Nicaenum II 1767a: Interpretatio subscriptionis: 134: "Thomas misericordia Dei presbyter et hegumenus monasterii sancti patris nostri Arsenii in Aegypto siti"). In fact, from the discussed period, we know the individual names of the representatives of the Melkite patriarchs of Alexandria at large assemblies of bishops related to difficulties within the Byzantine Church (Concilium Nicaenum II 1766: 1128-1136; Epistola sacerdotum Orientis 1766: 1136-1154; Epistola ad Alexandrinorum Ecclesiam 1767: 809-820).

The tradition of referring to the patriarch of Alexandria was maintained. This is clearly seen in Photios' confrontation with the papacy. At the synod convened in 867, he needed ideological approval of his actions from the patriarch of Alexandria. The dismissal of Pope Nicolas I (858-867) at the afore-mentioned synod was

Symbol of the past: the presence of representatives of Alexandria in the life of the Church 
allegedly supported by the Melkite patriarch of Alexandria (Liber Pontificalis 1892: vol. 2: 178-179; Concilium Constantinopolitanum IV 1771a: Causae et praefatio: 5; Hefele 1911: vol. 4: 447). Some historians, when analysing the sparse source material, point to the wilfulness of Photios I of Constantinople (858-867 and 877-886). He chose those representatives who would represent his point of view. These representatives were probably monks (Faivre 1914: 355). Alexandria was to be represented by a certain Leontius, who was bought out of captivity by the Melkite patriarch of Alexandria, Michael I (860-870). Two years later, at the first session of the Fourth Council of Constantinople (869), another representative of the bishop of Alexandria appeared, a certain Joseph, this time actually sent by the patriarch (Michael Alexandrinus 1771: 145-147; Concilium Constantinopolitanum IV 1771c: Actio decima-Canones 1771: 398-410). The envoy of Michael I supported the verdict condemning Photios. After Ignatios's death (877), Alexandria was represented by Cosmas, the representative of the next patriarch, Michael II (870-903), at the synod convened by Photios in 879 . There was also a shift in Alexandria's position. The patriarch's letters speak of the support that both Michael I and Michael II gave to Photios, and they rebut Joseph of Alexandria at the council of 869. Thus, the Melkite patriarchate of Alexandria took the same position as Antioch and Jerusalem (Pseudosynodus Photiana 1772: 259-263; Michael Patriarcha Alexandriae: 1772: Epistola: Beatissimo: 427-434; Epistola: Photio 1772: 441-444; Theodosius patriarcha Antiochiae 1772: 443-450).

As already mentioned (see Section 4.2.1), Alexandria was also involved in the problem of the fourth marriage of Emperor Leo VI (Dagron 1999b, 165) and the dispute between the patriarch of Antioch Simeon (890-907) and the metropolitan bishop of Damascus in 890-891 (Boudier 2018: 45-80).

Despite the "demographic marginalization" of the Melkites in Egypt, the opinion that the Melkite patriarchate of Alexandria was a "forgotten bishopric" in the early Middle Ages is not entirely true, at least because of the importance of the title of the ancient apostolic see. Single cases testify to attempts to revive the Melkites, or more precisely, to their willingness to mark their presence in Egypt. At the end of the 8th century, Patriarch Politianos (768-813), thanks to his medical abilities, managed to win the favour of Caliph Hārūna ar-Rašìd (786-809). With the support of the ruler, he tried to regain some of the Melkite Churches and monasteries, which, after the Muslim conquests, passed into the hands of the Copts (Nasrallah, Haddad 1979: 21). It is difficult to estimate the extent to which these activities have been taken; one may even doubt whether the Melkites recovered any temples at that time. 
It seems that the importance of the Alexandrian patriarchy declined throughout the 9th century. The year 879 showed that the Melkite patriarch of Alexandria was incapable of devising his own solutions, confining himself to supporting the activities of the patriarch of Constantinople. In the 10th century, the isolation and cultural decadence of the Egyptian Melkites increased even more (Faivre 1914: 355). While Patriarch Christopher (817-841[848]) preached in Greek in the 9th century (Christophori patriarchae Alexandrini homilia, PG, vol. 100: 1215-1232), 100 years later, Patriarch Eutychius of Alexandria or Sa'īd b. Bițrīq (933-940) wrote his chronicles in not very exquisite Arabic (Sa'īd b. Bitrīiq did not know Greek, but he had access to Greek texts in existing Syriac translations).

Eutychius of Alexandria, however, is one of the greatest Melkite intellectuals of this period. Sa '̄id b. Biṭrīq was from Fusțāt (old Cairo) and spent most of his life as a doctor. In 932, at the age of 60 , he became the Melkite patriarch of Alexandria. His appointment met with the opposition of many Melkites, since he had never held any office. Moreover, he was not accepted by many Melkites for the rest of his life (Eutychius 1909: 69-70). It is possible that the patriarch's throne was won due to the intervention of the Muslim authorities (Pummer 2002: 430). Eutychius of Alexandria was a contemporary of the historian Mahbūb b. Qūștānțīn (Agapius of Hierapolis), although they didn't know each other. The chronicle of Eutychius of Alexandria testifies to the relatively good discernment of the Alexandrian Melkites in the matters of the Church in Byzantium and the Middle East.

\subsubsection{The patriarchate of Jerusalem}

The chronology of the Melkite patriarchs of Jerusalem (750-969) cannot always be recreated precisely due the scarcity of the source material. It is as follows (Grumel 1958: 451-542; Fortescue 1919:

List of the Melkite patriarchs of Jerusalem, 750-969 355-364; Dowling 1913):

sede vacante [?]

Theodore I

Elias II

[Theodore Intruder]

George

Thomas I

Basileus

John VI

Sergius I

Sede vacante
$735-752$

$752-767$ or $745-770$

$770-797$ or $787-797(?)$

(?)-(?)

797-807 or (?)-807

$807-820$ or $808-821$

$820-838$ or $821-839$

839-843 or 838-842

$842-844$ or $843-859$ (?)

844-855 (?) 
Salomon

Theodosius

Elias III

Sergius II

Leontius I

Athanasius I

Christodulos I

Agathon

John VII

Christodulos II
$855-865$ or $860-865$ (?)

$862-878$ or before $867-878$ (?)

878-907

908-911 or 907-911

912-929

929-937

937-951 or 937-950 (?)

951-964 or 950-964 (?)

964-966

966-969
The Melkites between two "Roman Emperors": a new chapter in the relationship of the West with the caliphate
The second half of the 8th century was a period of stabilization between the Abbasid caliphate and the Christian states. However, we must not lose sight of the important changes that took place in Europe. During the pontificate of Stephen II (752-757), the papacy finally closed the Byzantine chapter of history, by bonding with the Franks. The pope entered into an act of friendship with Pepin (751-768), the first king of the Carolingian dynasty. This ruler fought not only with the Longobards, but also with the Arabs, whom he pushed to the Pyrenees. The patronage of the Roman Church officially passed from Byzantium to the Franks (Miller 1974: 79-133). The successor of Stephen II, Paul I (757-767), no longer informed the Byzantine emperor of his election, and Pope Adrian I (772-795) changed the date of the documents; afterwards, they were not dated as before, according to the reign of individual Byzantine emperors, but according to the years of the pope's pontificate. The alliance between Rome and the Franks proved even stronger when Pope Leo III (795-816) crowned Charlemagne as emperor at Christmas in 800. For the first time in three centuries, the title of emperor was restored in the West. Many historians consider it a symbolic turning away of the papacy from the collapsing Byzantine Empire and towards the new Carolingian power. With Charlemagne there was Renovatio imperii Romanorum, "the renewal of the Roman Empire." From then on, there were two figures with the title of Roman Emperor (McKitterick 1983: 70). The Byzantine authors, followed by Melkite patriarchs, however, viewed Charlemagne less favourably because of his support for the filioque and the fact that the pope preferred him as emperor over the first empress of the Byzantine Empire, Irena of Athens (752-803). These and other disputes led to ever greater divergences until the split between Rome and Constantinople in the Great Schism in 1054 (Gregory 2005: 251-252).

The improved relationship of the Carolingians with the Abbasid caliphate stemmed from the tensions between two Muslim dynasties: the Spanish Umayyads and the Abbasids. 'Abd ar-Rahman (731-788, caliph of Cordoba from 756) survived the massacre of 
his family by the Abbasid dynasty in 750 as the only male member of the Umayyads. He escaped to the Maghreb where, thanks to the Berbers' support, he headed the Arab army fighting the Abbasids. In 756, he took the title of emir and captured Cordoba. In 764, he captured Toledo. He quelled the rebellions and murdered his political opponents who were sympathetic to the Abbasid caliphate.

Taking advantage of the civil war in the Muslim world, Pepin regained Septamania and Aquitaine from the Arabs (752-759). Charlemagne had even more far-reaching plans. He wanted not only to ensure the stability of the country's southern borders, but also to seize all of Spain from the hands of Muslims. Scholars and contemporary accounts of the Carolingian chronicles agree that in the spring of 777 the pro-Abbasid governor of Zaragoza, who refused to submit to the rule of the Spanish Umayyads, came to Paderborn, asking for the intervention of Charlemagne. The emperor seized the opportunity to try to regain Spain for the Christian world. Although 'Abd ar-Rahman defeated Charlemagne at the Battle of Zaragoza in 777 and forced him to retreat, Charles' troops took over Gerona, Urgel, Cerdaña and Barcelona during the period 785-801 (Zimmermann 1989: 13-14; 433). A separate question is the extent to which mediaeval chroniclers and modern researchers considered these campaigns a religious war or a "progenitor" of crusades (Delaruelle 1941: 24-45; Rouche 1979: 130; Hämel 1924: 37-48; Erdmann 1977: 98).

There is a discussion among historians about a rather laconic mention from Annales regni Francorum about whether diplomatic relations were established between the Abbasid Baghdad and the Frankish Aix-la-Chapelle. Some scholars consider the existence of these relations highly probable or even a fact. They were supposed to be a natural consequence of the interests of the Abbasids and Carolingians (Bréhier 1919: 15-39). Suggestions that Pepin could try to establish contacts with the Abbasids in 756 are highly questionable, as the surviving sources do not give us any details about the negotiations (Borgolte 1976: 34-44). The policy priorities of the caliphate and the western empire at the turn of the 8th and 9th centuries were relatively clear to historians. The Abbasids did not interfere in Charlemagne's attempts to reclaim Spain, because Baghdad was fighting the Umayyad Caliphate of Cordoba. Charles was not involved in the caliphate's wars against Byzantium because he was in conflict with Constantinople. In this way, a kind of Christian-Muslim "alliance" existed, a political game to weaken both Umayyad Spain and Byzantium (Björkman 1965: 537-608; Ganshof 1961/1962: 1-53).

According to Annales regni Francorum in 797, three of his envoys (two of whom died on the way) left for Baghdad. Two years later, the 
priest Zachariah went on a mission to the patriarch of Jerusalem (Annales 1895: 187-190). In addition to his political goals, Charlemagne, according to Einhard, wanted to interest the Abbasid caliph, Hārūn ar-Rašīd (786-809), in the fate of the churches in the Holy Land and to have some opportunities to support them. Einhard wrote extremely compelling information that Hārūn ar-Rašìd "even handed over the sacred and salvific place, so that it might be considered as under Charles' control" ["sed etiam sacrum illum et salutarem locum, ut illius potestati adscriberetur concessit"] (Einhard 1911: 19).

Much research has been devoted not only to the extremely intriguing issue of the Frankish-Abbasid diplomatic relations (Latowsky 2005: 25-57; Schüppel 2019; Gabriele 2011: 34 40), but most of all to the handing over of Melkite Jerusalem to the care of Charlemagne. Basically, the tradition of Charlemagne's custody of Jerusalem is considered a symbolic narrative.

However, there are authors who believe that the supporters of the narrative of Einhard's symbolic account have not presented any new evidence that would unequivocally reject Einhard and Alcuin's information (Latowsky 2005: 28). There are also those who unequivocally state that Hārūn ar-Rašīd transferred administrative control over the Holy Grave to Charlemagne in 802 (Bréhier 1928: 24-25). The dispute focusses on the question of whether it was a real donation or a peculiar symbolic piece of land on which the Holy Tomb stood (Barbero 2004: 100-101), or treating Einhard's account as a confusing collection of unverifiable facts (Halphen 1947: 49).

The mediaeval biographies were not primarily based on facts but on rhetorical topoi, which seems to be questioning the literal interpretation of Einhard's information. The latest research focusses on topoi. Detailed comparisons show that biographies were structured according to episodes, the importance of which was often based on their rhetorical value. Establishing precise facts was often secondary to the rhetorical stylization (Morse 1991: 128-129). On the other hand, annals mentioning only the patriarch of Jerusalem handing over the keys to the Basilica of the Holy Sepulchre to Charlemagne could only be a legend (Graboïs 1981: 792-809; Hauziński 1993: 119-120). Doubts about the actual patronage of Charlemagne over the holy places are reinforced by the silence of the Byzantine and Melkite sources. In fact, researchers tend to believe in the traces and enigmatic references in Frankish sources. Nevertheless, it seems that Muslims realized that Charlemagne, as one of the two Christian emperors, claimed custody of Christianity in the manner of Byzantium. Charlemagne felt the gravity of this mission (Alkuin 1895: 137), and therefore, he tried to influence the fortunes of the 
Christians of Jerusalem by strengthening his position there (as evidenced by his material support).

Charlemagne's influence in Jerusalem generated many outcomes. First, the Roman emperor, as the guardian of Christianity in the world, was obliged to provide financial assistance to Christians in Jerusalem (Einhard 1911: 19-25). Second, despite the Muslim rule, Jerusalem retained a central religious function for Christianity. It was a pilgrimage destination and an important source of relics (Borgolte 1976: 100, 129; Graboïs 1981: 796; Schmid 1983: 124; Bieberstein 1993: 152-173). Third, during these years, about 60 monks and nuns from Western Europe were staying in Jerusalem, in the Monastery on the Mount of Olives that was founded or at least sponsored by Charlemagne (Borgolte 2013: 181). Fourth, although we do not know many details of Frankish-Abbasid diplomatic relations, the "presence of common interests" of Baghdad and Aix-la-Chapelle sheds some light on this interaction (Geis 2003: 2). Fifth, it is possible that the news of the attack on the monastery of Mār Sābā in March 797 probably reached Aachen in the same year, being an opportunity to focus more attention on Jerusalem (Bieberstein 1993: 229). Sixthly, Charlemagne probably paid attention to what was happening in the Middle East thanks to the Jewish merchants (Schüppel 2019). Seventh, it is also possible that Hārūn ar-Rašīid, who was influenced by Baghdad intellectuals, did not see any problem in the contact between Jerusalem and Christians of the West (Altmann 2003: 30-31; Weinfurter 2013: 242). Finally, some scholars suggest that Hārūn arRašĩd tried to strengthen the position of the Franks in Jerusalem to prevent the further tightening of ties between the patriarchate of Jerusalem and Byzantium, which became a fact again after the Second Council of Nicaea in 787 (Borgolte 1976: 122). Nevertheless, the hypothesis that the improvement of the situation of Christians in the Holy Land was a "common political goal" for Charlemagne and the caliphate (Geis 2003: 84) seems too far-fetched (Schüppel 2019).

Sources of the Carolingian era mention that the envoy of Charlemagne, Father Zacharias, returned to Rome with two messengers of the patriarch of Jerusalem (Theodore the Intruder [?]), who were monks, one from the monastery of St Saba, the second from the monastery on the Mount of Olives ("Eadem die Zacharias cum duobus monachis, uno de monte Oliveti, altero de sancto Saba, de Oriente reversus Romam venit"). The delegation arrived on 23 December 800, that is, on the day before Charles' coronation as emperor (Annales 1895: 112). The presence of the representatives of the patriarch of Jerusalem had its own symbolic and ideological implications; Charlemagne rose to the rank of the protector of Christianity in general, since the message from the Holy City even handed him the keys to the Basilica of the Holy Sepulchre

The contact between the Melkite patriarch of Jerusalem and Charlemagne and the papacy 
Financial support of Charlemagne and long-term repercussions of his politics for the Melkites
(Einhard 1911: 19). Notwithstanding those discussions on the historicity of Erhard's mention, Jerusalem forged a new relationship with the West, which once again had a Christian emperor. This is evidenced by the exchange of correspondence between the Patriarch of Jerusalem, the abbot of the Latin monastery on the Mount of Olives, Charlemagne and Pope Leo III. The Melkite Patriarch of Jerusalem, Thomas I (807-821), a famous physician from a Monastery in Wādi Harītūn, sent a delegation to Charlemagne in 807 , shortly after his appointment to introduce new regulations on liturgical matters. The messengers included a Greek from the monastery of St Sheba and Benedictine monks from the Monastery on the Mount of Olives (Epistola CXXIV: 359-360; Nasrallah, Haddad 1979: 14).

Charlemagne, in addition to the aforementioned material support of Christians in Syria, Palestine, Egypt, and Carthage, contributed to the maintenance and construction of new monasteries and churches in Jerusalem. Latin monasteries were erected on the Mount of Olives and near the Basilica of the Holy Sepulchre. Charlemagne also founded a complex for pilgrims on the site of the biblical "Field of Blood" (Mt 27, 8), which included a hospice, a basilica, a library, etc. This monumental support of Charlemagne was certainly still in operation in 870 , which the French monk Bernard, who made a pilgrimage to Palestine and Egypt with two companions in 865-886, confirms in his Itinerarium trium monachorum (Bernardus Monachus 1852: 572-573; Richard 1990: 391).

Although the great work of Charlemagne partially disintegrated with his death, his policy towards the Church in the Holy Land was still being implemented. First of all, alms sent to the Holy Land became a regular Western custom. Louis the Pious (814-840), faithful to his father's will, levied a tax on every property in his kingdom to help maintain the churches there. He also corresponded with the Melkite patriarch of Jerusalem, but it is highly doubtful that he had an "ambassador" to the caliph's court. Popes also undertook actions of material aid for Palestine. In 879, Pope John VIII (872-882), who considered "defence against the Saracens" to be one of the main tasks of his pontificate, seized the opportunity to send financial support to Jerusalem through three Eastern monks residing in Rome. Besides, the patriarchs of Jerusalem themselves sent their emissaries to Europe, asking for help. In 881, the Melkite Patriarch of Jerusalem, Elias III (c. 878-907), asked the Emperor and all the princes of Europe for help in maintaining and reconstructing the churches of the Holy Land. In turn, in AD 900, the same patriarch asked for money to be sent for the redemption of Melkite monks who had been taken captive by the Turks (Bréhier 1928: 27). 
The Melkite patriarch of Jerusalem, Theodosius (c. 867-878), in a letter dated 869 to the patriarch of Constantinople Ignatios (847-858; 867-877), praised the generosity of Muslims who allowed Christians to build churches and live according to their customs and laws (Ignatius Patriarcha Constantinopolitanus 1771: 26). The pilgrims did not encounter any major difficulties in visiting the Holy City, as evidenced by the aforementioned French monk Bernard. The author especially admires the safety of travel, which was guaranteed by the safe conduct of the Muslim authorities (Bernardus Monachus 1852: 570). In the 10th century, the pilgrimage movement increased, which is confirmed by the biographies of secular and church dignitaries of the era. For example, it is worth mentioning that Conrad, bishop of Constance (died 975), visited the Holy Land three times (Chuonradus Constantiensis 1841: 429-445).

Attempts by the West to gain influence in Jerusalem were not welcomed in Constantinople. In the Greek sense, Byzantium was the rightful successor of the Imperium Romanum and the protector of Christianity in Jerusalem.

\subsubsection{Melkites East of the Euphrates}

When the Abbasids moved the capital of the caliphate from Damascus to Baghdad, there was a Melkite community in the city. The Arab-Byzantine wars increased the proportion of Melkites, as many Greek Christians were taken captive. The Melkites apparently made up a "significant" (difficult to quantify today) share of Baghdad's population since one of the neighbourhoods of the Abbasid capital was called Dār ar-Rūm (which might be translated as "Melkite district"). With this process of the growing importance of this community, a dispute arose within the Melkites in the former Sassanid territory over where the catholicate should be. The Melkites from Central Asia argued that the catholicos migrated from Seleucia-Ctesiphon with the displacement of Christians to Tashkent. The Melkites of Baghdad believed that catholicos should reside there because the Abbasid capital and Seleucia-Ctesiphon were located in the same administrative unit. Catholicos Rumagyris had the ambition to reside in Baghdad. Since the hierarch did not consent to the transfer of the seat of the catholicate to the caliphate, the Baghdad Melkites turned to the Melkite patriarch of Antioch, Elias I (907-934), for help. Ultimately, the matter was settled in favour of two catholicos. However, the Patriarch of the Church of the East Abraham III (905-937) successfully blocked the rise of the Melkite Catholicate Church in Baghdad in 912 (Fiey 1995: 387-389; Parry 2012: 98;

Development of Melkite communities in Baghdad 
Conflict between the Melkites and the "Nestorians"; Fall of the ideas of the Melkite Catholicate of Baghdad in 912
The second approach: establishing the Melkite Catholicate in Baghdad
Wilmshurst 2011: 193; Ibrāhīm ibn Yūḥannā al-Anțākī 1952: Vie du patriarche: 23-25; Allard 1962: 380; Nasrallah, Haddad 1979: 9).

The "Nestorian" counter-action against the Melkite bishop John in Baghdad, who was sent by Elias I, exacerbated the divisions between the Christians of the Caliphate. This interaction is understandable in the context of the position of the "Nestorian" patriarchs, who had exceptional privileges in the caliphate. After the persecution of Caliph Mutawakkil (852), the "Nestorian" patriarch was the most powerful church hierarch tempted to claim-with the consent of the Muslim ruler - the right to supremacy over all Christian communities of the caliphate (Massignon 1942: 7-14; Nasrallah 1976b: 59). Abraham III not only forbade John from using the title of catholicos, but also from developing the Melkite hierarchy in Baghdad. The chroniclers provide some details of this event. On the initiative of the "Nestorian" patriarch, the Caliph's administration was to be bribed. According to Bar Hebraeus, 30,000 dinars were offered to the Muslim official (Bar-Hebraeus 1874: 235), while Mārī b. Sulāymān writes about 10,000 dinars given as a bribe (Mārī ibn Sulāymān 1896: 1: 92-93). John was condemned, fined and forced to leave the capital. Soon after, the Persian official of the Abbasid Caliphate 'Alī b. 'İsā b. Dā'ūd b. al-Ğarrāḥ (859-946) went to Elias I, the Melkite patriarch of Antioch, forbidding the appointment of a catholicos or metropolitan bishop in Baghdad. The Melkites of Baghdad only obtained the right to occasionally receive a bishop from the patriarchate of Antioch, and not for his permanent residence in the capital of the caliphate. It seems that the Christians in the caliphate capital were then overwhelmingly dominated by the "Nestorians" (Bar-Hebraeus 1874: 2: 235; Mārī ibn Sulāymān 1896: 1: 92-93; Sourdel 1960: 2: 518-551).

About half a century later, new efforts were made to establish a Melkite Catholicate of Baghdad. They were a reaction to the death of the catholicos of Melkite, Rumagyris. Delegations from Central Asia as well as from Baghdad arrived in Antioch, asking the Patriarch to designate a hierarchy that would guarantee the durability of the Melkite Church. Little known to historians, Patriarch Agapius I (953-959 before 960) or Agapius b. Qa barūn did not dare to ordain a bishop for Baghdad, but only appointed a new catholicos for Rumagyris instead (Agapius I is signalled by a document from the 10th century, published under the title Vie du patriarche melkite d'Antioche, Christopher from 967 [Ibrāhīm ibn Yūhannā al-Anțākī 1952: Vie du patriarche: 25] and Yahyā b. Sa 'īd of Antioch [Yahya b. Sa'id 1924: 770]). When Christopher (960-967) ascended the throne of the patriarch of Antioch, the situation changed. The new patriarch had a good relationship with Emir Sayf ad-Dawla (944-967). Thanks to the ruler's protection, Christopher obtained the consent of the 
caliph himself to establish a Melkite bishop in Baghdad. The first Melkite catholicos to reside in the capital of the Abbasid Caliphate was Măğid from Aleppo, the titular bishop of Irenopolis, who was appointed between 960 and 967 (Ibrāhīm ibn Yūḥannā al-Anțākī 1952: Vie du patriarche: 29; Nasrallah 1970: 168; 1976b: 60). The Melkite Catholicate in Baghdad is also mentioned in the Antiochian Notitia episcopatuum from the second half of the 10th century (Papadopoulos-Kerameus 1884: 65-67).

Unfortunately, due to the lack of sources, we are unable to reproduce the list of Baghdad's bishops in the 10th and in the following centuries. There are only some rare references to Melkite catholicos. For example, in his Typicon, a Byzantine monk Nikon of the Black Mountain (c. 1025-1105) mentions a catholicos of Baghdad named John and places his episcopal ministry during the reign of the Antiochian prince Nikephoros Uranus, that is between 999 and 1006 (Nasrallah 1970: 150-162). The Melkite Catholicate of Baghdad or the Catholicate of Irenopolis roughly covered the territory of today's Iraq.

It is difficult to say to what extent the Melkites of Central Asia carried out missionary activities. It is known that during the period in question there were Christians among the Turkic peoples (Barthold 1935: 104), but rather not of Melkite denomination. Certainly the "Nestorians" showed the greatest missionary commitment in Asia. Nevertheless, the presence of Melkites in Central Asia is confirmed by much later sources, so it can be assumed that they were present throughout the period in question (Dauvillier 1953: 62-87). For example, one of the bulls of Pope John XXII (1316-1334) testifies to the existence of Melkites in Samarkand (Oriens Christianus 1740: 3: 1377). Throughout its existence, this Catholicate was associated with the Melkite patriarchate of Antioch, which is also confirmed by Armenian sources (Recueil 1906: 264).

\subsection{Melkite monasticism and literature}

Between 750 and 969, Melkite monasticism developed the least in Egypt because the vast majority of monasteries in the country on the Nile belonged to "monophysical" Copts. Unlike in Egypt, Melkite monasticism developed well, despite some difficulties in Syria, and mainly in Palestine. Traditionally, the monasteries of St Catherine in Sinai and St Saba in Palestine played a leading role.

\subsubsection{The condition of the Melkite monasteries}

Several factors contributed to the weakening of Melkite monasticism. The first one was the powerful earthquake on 18 January 746, which

The weakening of Melkite monasticism 
Hospitality of monasteries towards Muslims

The monastery of St Catherine in Sinai caused terrible destruction, especially in Palestine. Another factor very unfavourable for the development of monasticism was the high taxes imposed by the Muslim authorities on monks. On top of all this, there were also Bedouin robbers, whom the Muslim authorities tolerated with a peculiar indifference. There were also periodic persecutions (Nasrallah, Haddad 1979: 12).

The difficult situation of Melkite monasticism is evinced, for example, by the martyred monks from the monastery of Mār Sābā: St Christopher in 789, St Stephen of Mār Sābā (c. 725-c. 794) in 794 and as many as 20 monks in 797 . In the years $809-813$, as a result of the civil war between the sons of Hārūn ar-Rašīid, the situation became so serious that most of the monks left the monastery, seeking refuge in Christian lands (Theophanes 1885: 277-278; 282-283).

Melkite monasteries were visited by both Christians and Muslims. They accepted many travellers because they were located in the wasteland and always had sources of water. It is difficult to find a monastery that would not host a caliph or Muslims during their travels or military campaigns at least once. The sources mention many poets and state officials who regularly visited the Melkite monasteries. The eminent Arab geographer and writer Šihāb ad-Dīn Abū 'Abd Allāh b. Yāqūt al-Hamawī ar-Rūmī or al-Yāqūt (1179-1229) confirmed this over 200 years later. Al-Yāqūt was delighted not only with the hospitality, but also with the eloquence of the monks (Nasrallah, Haddad 1979: 12).

In his anthology of poetry, Abū Manșūr at-Ta'ālibī (961-1038) included the work al-Halidī, which praised the Melkite monks from the monastery in Dair Murrān for their focus, mortification, and excellent knowledge of literature, philosophy, poetry, medicine, and other sciences (Ta 'ālibī 1885: 1: 512-513).

The Melkite monastery of St Catherine in Sinai had been dominated by the Greek culture and language for a long time, but the situation began to change. Gradually, Arabic started to gain more and more importance. It is believed that it was here that some of the first translations of Greek texts into Arabic were made. In the 9th century, the monastery accepted the call of St Catherine, and its superior was elevated to the dignity of archbishop. This extremely important centre of Melkite monasticism was situated on the border of the patriarchates of Jerusalem and Alexandria. From time to time, this caused disputes among the patriarchs over the jurisdiction of the monastery. It seems that it was subordinated to the patriarch of Jerusalem until the Crusades. Unfortunately, we only know the individual names of the archbishops who resided in the monastery in Sinai between 750 and 969. One of them was Constantine I, who signed the documents of the Fourth Ecumenical Council in Constantinople in 869 (Subscriptiones 1771: 194). After him, we learn 
about Archbishop Solomon also from the laconic reference to the manuscript of Sin.arab. 2 (from 930) (Eutychius 1909: 416; Nasrallah, Haddad 1979: 13).

There were no great Greek or Arabic writers in the Sinai monastery during this period. However, many translations were made from Greek into Arabic, among which the following survived: an excerpt from the Bible, liturgical books and the selections of thoughts of the Church Fathers. The monks therefore focussed on rewriting Greek, Syrian, and Arabic manuscripts. In total, many manuscripts have been preserved in the Sinai library (e.g. 11 texts from the 9th century and three manuscripts from the 10th century), three of which are dated 831,867 , and 897 . There are also a number of manuscripts scattered all over the world, most of them in the Vatican Library (Nasrallah, Haddad 1979: 13-14; Prévost 1937: 108-115).

At this time the Melkites in Egypt had probably just one monastic centre. There is information about a monastery in al-Qusayr. This place was particularly enjoyed by the founder of the Tulunid dynasty, Aḥmad b. Țūlūn (868-884). His biographer, Al-Balawī (10th century), mentions that the ruler liked to spend time in this monastery. According to this chronicler, Ahmad b. Țūlūn visited the monastery often. The caliph used to shut himself in one of the monastic cells to meditate. He also spoke with particular pleasure to a monk named Antonius (Balawī 1939: 118). Also, Emir Hummarawāyh (884-896), the son of Ahmad b. Țūlūn, purportedly had his own favourite cell in the monastery. Apparently, he especially liked to meditate in the church in front of the mosaics depicting Christ, the Mother of God, and the 12 apostles (Abu Salih 1895: 49-51).

The end of the golden age of the monastery of Mār Sābā fell on 20 March 797, when the Bedouins set fire to the monastery, as a result of which not only a large part of the building burnt down, but also 20 monks died of suffocation (Bibliotheca Hagiographica Graeca 1957: 1200). A few years later, the monks of this monastery were decimated by a terrible plague. A monk from the monastery of Mār Sābā, Leontius of Damascus (9th century), mentions that two or three monks died every day during this epidemic.

In turn, between the year 809 and 813, the aforementioned civil war between the sons of Hārūn ar-Rašīd caused the destruction not only of the monastery of Mār Sābā, but also of the monasteries of St Chariton, St Euthymius, and St Theodosius in the Melkite patriarchate of Jerusalem (Theophanes 1885: 277-278; 282-283). Despite these misfortunes regularly befalling the Melkite monasteries, monastic life was laboriously reborn after each successive defeat. The monasteries of Mār Sābā and St Chariton remained the cultural centres of the Melkites in the patriarchate of Jerusalem. Most of the patriarchs who undertook pastoral service came from there.

The Melkite monastery in Egypt

The Palestinian monasteries 
The Melkite monasteries of the patriarch of Antioch

The surprising paradox: Byzantization in the context of Arabization
There were monks who were messengers both to Constantinople and to the court of Charlemagne. For example, two brothers, monks from the monastery of Mār Sābā, St Theodore Graptos (died c. 844) and St Theophanes Graptos (died 845), went on a mission to Byzantium in the wake of the iconoclastic disputes (Kazhdan, Gero 1987: 122-132).

It is very difficult to recreate the situation of Melkite monasteries in Syria: the Monastery of St Simeon Stylites played the main role among them. The preserved inscriptions provide us with some information about this most famous monastery in the Melkite patriarchate of Antioch. For example, the monk Antonius from this monastery left us many Arabic versions of various patristic works (Nasrallah 1970: 168-171). Moreover, the presence of monastic life in northern Syria is confirmed by the remains of several other smaller monasteries such as the one in Teleda (Tchalenko 1956: 136).

\subsubsection{Between Greek and Arabic: Melkite theology and historiography}

In the 8 th and especially in the 9th century, two parallel processes of Byzantinization and Arabization of the Melkite community, particularly in the patriarchates of Jerusalem and Antioch, gradually intensified. Although Arab culture was originally largely related to Islam and Byzantine culture to Greek, these two phenomena only seemed contradictary. Byzantinization did not develop as a direct result of Arab invasion in the 730 s, or the periodic Muslim persecution. Many liturgical manuscripts from these centuries reveal that the process of Byzantinization developed gradually and locally contributed to the transformation of the Melkite rites. It was by no means an element imposed by Byzantine imperial policy or an expression of the ambitions and claims of the patriarchate of Constantinople. Rather, Byzantization was a grassroots process (Galadza 2013: 75-94; 2018). It was a progressive adoption of certain elements which simply attracted the Melkites and were useful to the Melkite clergy in enriching their rite. Paradoxically, then, Byzantization was combined with Arabization, that is, the emergence of the Byzantine rite in Arabic. Moreover, the international character of Jerusalem, due to its position in the Christian world in the context of the rich cult exercised by the Christians of the East and West, favoured this kind of interaction (Fiey 1969: 113-126), becoming a kind of a hallmark of the worship of Jerusalem. There was a phenomenon of the changing sacred Melkite topography of Jerusalem (Galadza 2013: 75-94; 2018). In this way, in the 9th century the distance between Jerusalem and Constantinople was paradoxically growing (Griffith 1997: 231). 
The Melkites simply became more and more independent in shaping their cultural identity, by drawing from both the Byzantine Empire and the Arab world.

The Melkite monasteries in Palestine responded to the needs of the pluralism of Oriental Christianity in terms of language culture. Using Greek in the 8th and 9th centuries (Blake 1965: 367-380), the Melkites translated Greek texts into Syriac and Georgian. Christian Aramaic texts from Palestine and Syriac manuscripts from the patriarchate of Antioch testify that the Melkites used two dialects of Aramaic alongside Greek (Leeming 2003: 240). Greek and Georgian texts were dictated, for example, by contact with the Christian outside world. The interaction with the Georgian Church testifies to the contribution of the Palestinian Melkites to the development of the Orthodox liturgy in general (Jeffery 1994: 1-38). Another parallel phenomenon that influenced the Melkite communities was the process of Arabization, which progressed in the caliphate.

The relatively large number of Arabic manuscripts from the 9th and 10th centuries confirm the grounding of Melkite Arab culture in the monasteries of Palestine. In fact, we have several genres of Arabic texts, which seems to confirm the good acculturation of Melkite communities. Kate Leeming raised a very interesting question: why one fundamental category of texts is missing, namely, Arabic prayers and hymns. In fact, Arabic was most likely becoming the language of prayers. This shows a good relationship between the monasteries of Mount Sinai and Mār Sābā in the context of the cultural exchange of translations. The Melkite Arabic liturgical texts also survived as the unidentified palimpsests in Greek manuscripts (Leeming 2003: 245). In turn, among the surviving Arab gospel lectionaries in the Mount Sinai monastery, Robert Turnbull singled out 12 families of biblical manuscripts according to their types and similarities in content. It is significant that the families of continuous texts, marked by the author as A and B, were copied mainly in the 9th and 10th centuries (Turnbull 2019: 131-166, esp. 164-166). Some of the manuscripts of Mount Sinai are especially important, for example Sinai ar. 116 , from the end of the 10th century. The Greek-Arabic lectionary is one of the fundamental sources for reconstructing the ancient Hagiopolite lectionary system of Jerusalem (Galadza 2018: 368-369; Turnbull 2019: 138).

Between 750 and 969, several valuable works were written by Melkite authors. It is worth presenting the most important thinkers, while omitting Bishop of Ḥarrān Theodore Abū Qurra (who will be discussed in more detail in Section 4.3.3 on the Melkite polemic with Islam).

Their presentation should begin with Politianos, the Melkite patriarch of Alexandria, whose years of episcopal ministry are dated differently by individual scholars (Grumel 1958: 443,

Patriarch of Alexandria Politianos (768-813) 
The Alexandrian patriarchs Eustachius (813-817), Christopher (817-848) and Sophronius (848-860)

Sa īd b. Bițrīq, or Eutychius of Alexandria: Melkite patriarch of Alexandria (933-940)

Mạ̣būb b. Qunsțanțīn alMambiğī and Qusțā b. Lūqā al-Ba labakkī
767-801; Faivre 1914: 366). He had great medical skills, thanks to which he managed to win over the caliph and regain several churches for the Melkites. Politianos was also a good lawyer. Unfortunately, his works have not survived to our times (Nasrallah, Haddad 1979: 21-22).

In turn, the Alexandrian patriarch Eustatius (813-817), associate and successor of Politianos in the capital of St Mark, was involved in the production of linen before joining the monastery. He then became a monk and the superior of the al-Qușayr monastery. Eustatius wrote homilies in honour of the Virgin Mary.

Patriarch Christopher (817-841[848]) became famous as a coauthor (together with the patriarch of Antioch, Job [813/814-844/ 845], and the patriarch of Jerusalem, Basil [821-839]) of the famous letter against the iconoclasts addressed in 830 to the Byzantine Emperor Theophilus (829-842). A parable on human life has been preserved from among his writings. The theme of the work is the fight of the Christian soul against the ancient serpent, Satan. The successor of Christophorus, Sophronius (848-860), was classified by the historian Eutychius of Alexandria as a philosopher. We know his two theological treatises: the first one on the veneration of the Holy Cross, and the second one against the iconoclasts. These authors wrote in Greek (Graf 1947: 2: 256; Nasrallah, Haddad 1979: 22-23).

One of the most outstanding Melkite writers of this period, Sa îd b. Bitrīq, or Eutychius of Alexandria - the Melkite patriarch of Alexandria - has already been mentioned several times. This author had versatile interests. Apart from his famous chronicles, thanks to which he gained the honourable title șahab at-tārīh for posterity, it is worth mentioning his work in the field of medicine, the lost treatise Kitāb fi t-tibb, which was known to the famous Arab physician Ibn Abī Ușaibi'a (1194-1270). Sa īo b. Bițrīq made use of a vast body of knowledge of ancient medicine in his writings. Eutychius of Alexandria also became celebrated as an ardent apologist. In the work Kitāb al-ğadal baīna l-muhālaf wa n-nașrani, which, unfortunately, did not make it to our times, Eutychius of Alexandria defended the Chalcedonian Orthodox faith with great zeal. Today, only his chronicles show how critical he was of the heresies of the first centuries of Christianity and of his contemporaries: the "Nestorians" and the "Jacobites" (Graf 1911: 227-244; 1947: 2: 32-38; Nasrallah, Haddad 1979: 2-34; Troupeau 1978: 209-220).

Another outstanding Melkite historian was Agapius, the bishop of Mambīğ, or Maḥbūb b. Qunsțanțīn al-Mambiğĩ (died 945). He left us the universal history Kitāb al- 'Unwān (Agapius 1910: 562-691; 1911: 459-591; 1912: 396-547; 1915: 5-144). Although scholars nowadays accuse it of lacking originality in its account of ancient history, it was quite popular among Muslims in the Middle Ages. It was praised by 
'Alī b. Husayn al-Mas' ūdī (died in 956) in his Kitāb at-Tanbīh wa- 'lišrāf: "the most beautiful work on the history of kings, prophets, peoples and countries that I have seen among the Melkites are the treatises of Maḥbūb, son of Maḥbūb b. Qunsțantịn al-Mambiğ̣̂" (Maçoudi 1896: 212). It was also quoted by the Arabic scholar Ibn Šaddād (died 1285) in his A 'āa al-hatīra (Ibn Šaddād 1963: 129-187). The version of Kitāb al-'Unwān we have today begins with the creation of the world and ends in AD 780 (the most famous manuscripts of this work are Bodl.arab.christ.Nicoll 51, $1^{\circ}$-Hunt 478; Sin.arab. $580^{\circ} 1$ from year 989; 456, fol. $103-164 v$ from the 13th century; Nasrallah 80 from the 17th century; Saint-Sépulcre arab. 93 from the 18th century; Nasrallah, Haddad 1979: 52).

The Syriac Melkite Qusțā b. Lūqā al-Ba labakkī (820-912) was a famous physician, philosopher, astronomer, mathematician, and translator. He was originally from the patriarchate of Antioch (born in Ba labakk). He was said to collect many Greek manuscripts, which he translated into Arabic with interesting comments and corrections. Qusțā fluently knew Greek, Syriac, and Arabic, in which he wrote many original scientific treatises. He pursued an academic career in Baghdad, where he knew numerous scholars and Muslim aristocrats. Several preserved scientific works of Qusțā concern the theoretical and practical aspects of astronomy (Hockey 2007: 948-949). On the other hand, the historical works of the Melkite author Qusțā b. Lūqā (820-912) are only known to us from the title of the work Kitāb alfirdaws fì tārīh (mentioned in Fihrist of Ibn Ishāq al-Nadīm). It was dedicated to the history of the world (Graf 1947: vol. 2, 28-29; Nasrallah, Haddad 1979: 52-53). The author also engaged in polemics with Islam (Qusțā ibn Lūqā 1981: Une correspondance; ZilioGrandi 1998: 677-689).

Also the patriarch of Antioch, Job (813/814-844-845), deserves a mention. He collaborated with the "Nestorian" catholicos, Timothy I of Seleucia-Ctesiphon (780-823), on the translation of Aristotle's Topics. During his ministry, Job was repeatedly drawn into the whirlwind of events that caused him enormous trouble. It has already been mentioned that in 822 Caliph al-Ma 'mūn (813-833) forced the patriarch to crown a certain Thomas, a rebel who, by the caliph's will, led the army against Emperor Michael II (820-829). The rebel was defeated by the Byzantines, and the patriarch of Antioch was excommunicated by Constantinople (Theophanes continuatus PG vol. 109, 68; Michael le Syrien 1905: 3: 75; Ioannes Antiochenus 1864: 1117-1148; Troupeau 1999: 329; Vasiliev 1932: 361-363; Vasiliev, Honigmann 1935: 22-49; Lemerle 1965: 255-297). Job was a tragic figure. As mentioned above, he died during the siege of Amorion in 838 , when he was forced by the caliph to participate in the war. This patriarch was the author of the homily for the celebration of the Holy

The Patriarch of Antioch Job (813/814-844/845) 
Arab poets of Melkite origin?

Polemics among Christians: "antiMelkite" literature

Geography and chronology of the Arabization of the Melkites
Cross, but the 11th-century manuscript, which was kept in the British Museum (Brother Mus. Or 5019), has unfortunately been lost under mysterious circumstances (Nasrallah, Haddad 1979: 34-35).

It is believed that the Melkites also dealt with poetry during the early Abbasid period. Louis Cheikho (1859-1927), after painstaking research, presented 44 excerpts of Christian poetry from the Abbasid times (Cheikho 2008: vol. 2). Modern research has shown that this heritage is even richer. Of course, when we talk about Christian poets, we mean the authors of all the Churches, among which the "Nestorians" prevailed. It is difficult to determine exactly to what extent the Melkites practiced poetry. Only traces of poets of Melkite origin have survived, one of whom is probably the apostate Abū Tammām (804-846). None of the Muslim writers dispute that his father was a Christian. Abū Tammām himself abandoned Christianity in favour of Islam during his stay in Egypt, where he sold water in a large mosque. He was a panegyrist of the caliphs. In addition to his Hamāsa, an extensive anthology of Arab poets, which he created owing to the possibility of working in a library, the author left behind a diwān, a valuable collection of poetry (Brockelmann 1943: 1, 83-85; Nasrallah, Haddad 1979: 43-45; Ritter 1960: 157-159). It is worth noting that the name of the famous Muslim poet Ibn al-Rūmī or Abū al-Ḥasan Alī b. al-Abbās b. Ğūraiğ (836-896) points to his Melkite (Rūm) origin. In fact, he was the grandson of Gūraiğ (Georgius) or George the Greek, the popular poet of Baghdad.

In this period, the anti-Melkite texts were written in both the framework of "Jacobite" and "Nestorian" Churches. First of all, a mention should be made of the four treatises by Habīb b. Hidma Abū Rầița 1-Takrītī (died c. 830), in which apologetic methods were coupled with the principles of Hellenistic philosophy (Thomas, Roggema 2009: 567-580). On the "Nestorian" side, 'Abdišo' bar Bahrīz (first quarter of the 9th century), the metropolitan bishop, first of Harrān, and later of Mosul and Hazza, argued with the Melkites. Ibn al-Nadīm cites 'Abdišo's treatise in defence of "Nestorian" Christology, which contained a response to works on "Jacobite" and Melkite Christology. The author criticized the belief in the "unity of hypostasis," which Ibn al-Nadīm described as 'Abdišo's wisdom that is close to Islam. The inter-confessional discussions are also evidenced by an anonymous text about a short Christological exchange between the "Nestorian" Muṭrān 'Abdišo' bar Bahrīz, the Melkite bishop Abū Qurra and the "Jacobite" thinker Abū Rā Rița in front of a Muslim vizier (Keating 2006: 352-257; Roggema 2018).

Culturally, this epoch could be called a time of cultural transformation. The Melkites in the Middle East and Egypt were dragged into a strong whirlwind of Arabization. This process was also 
reinforced by the importance of the Arabic language, which began to dominate in administration and in schools. In the 8th and 9th centuries, the monasteries of St Catherine in Sinai, St Sheba in Palestine and St Simeon Stylites in Syria tried to cultivate their Greek traditions. However, Arab culture also made its way into these enclaves. The Arabic language began to dominate first among the Melkites of Baghdad, and then in Mesopotamia and northern Syria.

Syria was bilingual until the time of the conquests. In the cities, Greek officials and burghers commonly used the Greek language. The Syrian peasants, on the other hand, used different dialects of the Aramaic (Syriac) language. After the Arab conquest, the situation changed. The Greek language disappeared quite quickly in cities, while the process of displacing Syriac from the countryside was slower. Arabization, however, was an extremely progressive phenomenon since by the second half of the 8th century the Melkites also began to use Arabic in theology. The first Melkite theologian to write in Arabic was Bishop of Harrān, Teodor Abū Qurra (c. 740-820). Nevertheless, this author expressed his theological thoughts even more freely in Greek than in his texts written in Arabic. It is assumed that at the end of the 8th century, Arabic became the dominant language in the Melkite patriarchates. It was not only the language of everyday life for the Melkites, but also entered the churches. The hierarchy of the school used this language very well, and even much better than Greek, as evidenced by the fact that at the Fourth Council of Constantinople (869-870), as it has already been mentioned, Thomas, the Melkite bishop of Tyre, delivered his speeches through an interpreter.

In the early 9th century, in Syrian cities such as Damascus and Homs, Arabic became the language of the Melkite townspeople. On the other hand, the Melkite monasteries located in the wilderness were most often taken by Bedouin tribes as their neighbours. It contributed to the penetration of Arabic into the daily and liturgical life of monks. From the 9th century on, the monasteries of Mār Sābā, St Chariton, and most of all St Catherine in Sinai, were the guardians of orthodoxy, already expressed in Arabic. Of course, during 750-969, treaties were written in Greek, but these were works written by monks who knew the language very well, that is, by a definite minority of religious authors. The oldest Christian Arabic manuscripts have been found in the above-mentioned monasteries, including the famous hagiographic manuscript including Vat. Arab. 71 from 885 (Griffith 1986: 117-138; Nasrallah, Haddad 1979: 48-49, 95).

Anti-Islamic polemics, apologies of Christianity and Christological disputes between Christians carried out in the context of the Arabization of the caliphate led to the crystallization of the Christological Arabic A new challenge: Arabic Christological terminology terms (Anonymous 2014: 40-59). What is most astonishing is the variety of terms used to express the Holy Trinity. Contemporary Arab Christian 


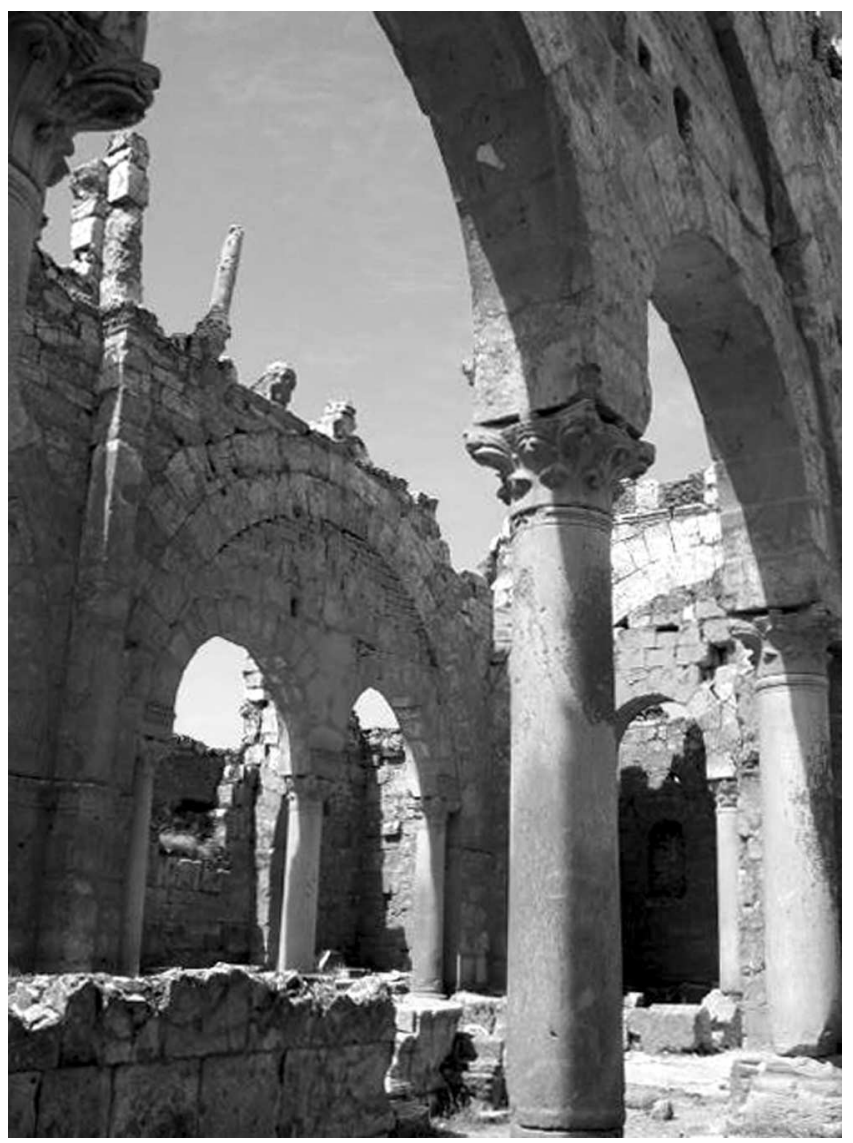

Figure 4.2 Basilica of St Sergius in Sergiopolis_-Rușāfa (the author's private collection).

theologians most often use the term $\operatorname{tabi}^{-} a$ to denote divine nature. Meanwhile, in the Middle Ages, Arab Christian thought had many equivalents to express this concept (Haddad 1985: 161-185). Sa ${ }^{i} \mathrm{i}$ b. Bitrīiq, quoted often in this book, writes that "The Father, the Son and the Holy Spirit are one (كيان واحد) in three hypostases (ناحة) (جانثة), one substance (جوهر), one nature (طبيعة)" (Eutychius 1906: vol. 1: 146). Eutychius of Alexandria, like many other Christian authors (e.g. Ibn alMuqaffa ' [died c. 759]), used the terms ğawhar, $\underline{d} \bar{a} t$ and kiyān synonymously to denote the divine nature (Haddad 1985: 162). Therefore, it is worth remembering that the same Arabic words used by Arab Christian theologians often meant a different reality than in the theological language of Islam. Part of the problem was the culture of the classical Arabic language, which had a strong relationship with the Qur'ān. 
Probably, for some Christians, Arabization could appear as a stage in the process of Islamization. Given the complex process of Arabization, however, it is difficult to determine whether, for the Melkites, it meant the danger of losing their Greek and Syriac cultural roots. On the other hand, it is possible that Arabization was one of the ways to oppose Islamization, which, as a means of integrating the caliphate, was supported by the Abbasid rulers (Samir 1981: 93-164; 1989: 251-309; Kościelniak 2000c: 289-306; 2001a: 1-19; 2001b: 185-190).

Anyway, the entry of the Melkites into the circle of Arab culture was relatively successful. Two types of Melkite literature were developed between the 8th and 9th centuries. The first group included works written in the literary Arabic language (fusha), mainly translations of the Greek heritage in the field of philosophy and medicine. This literature was addressed to the science elite, both Christians and Muslims. The second type of writings included hagiographic, ascetic and literary works (e.g. Hagiography 2014: 136-159). The recipients of this type of literature were monks and literate Christians. Thus, the addressees influenced the style of these works. Depending on the needs, these were either bilingual treaties, that is, Arab-Greek, or sometimes trilingual, that is, Arab-Greek-Syrian. It is supposed that for some Melkites who used Syriac, classical Arabic was as difficult as Greek (Nasrallah, Haddad 1979: 40-41).

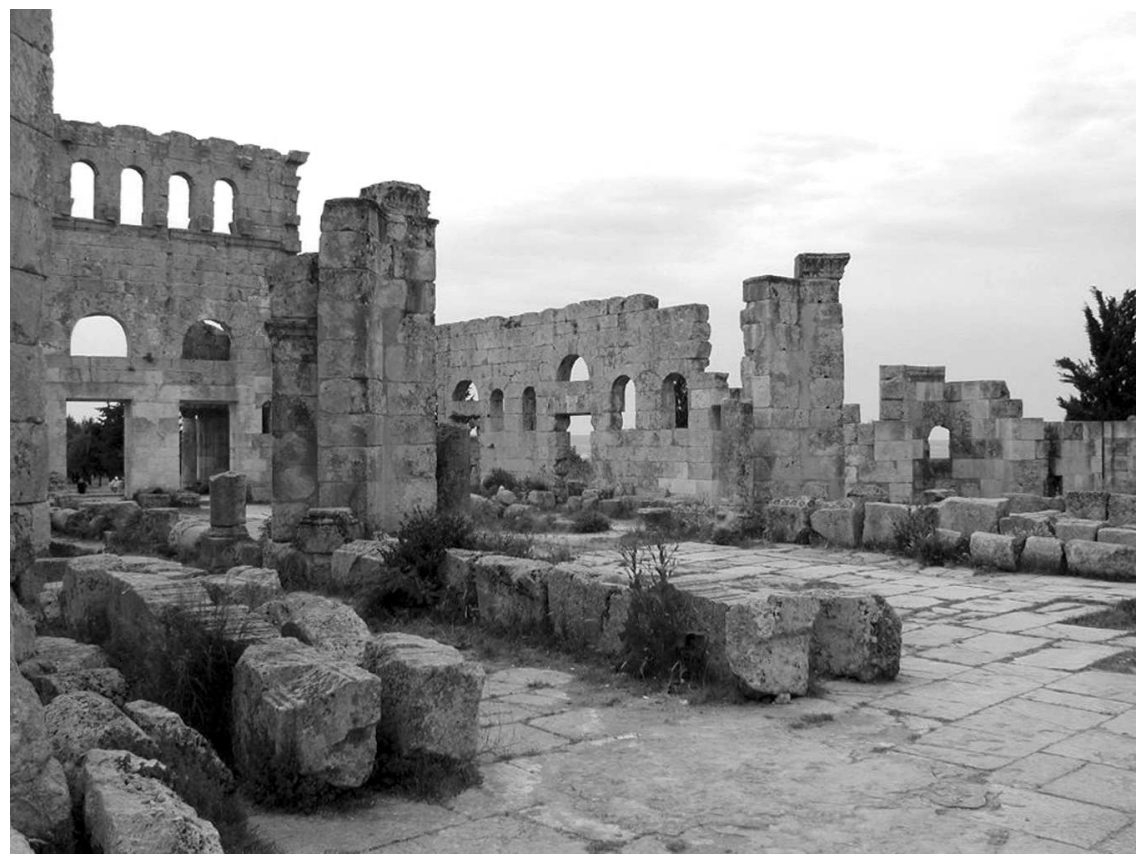

Figure 4.3 Part of the Simeon Stylites Basilica. Basilica(the author's private collection). 
From time to time, dominant languages appear in history. In ancient times, the Greeks were tempted to regard anyone who did not speak Greek as a barbarian. In the era of the domination of the Muslim world, Arabic first challenged Greek and then began to displace it. It became the language of science and poetry. The Melkites had to come to terms with this fait accompli, but behaved similarly to the Persians. The Persians, guarding their autonomy and being proud of their history, wrote in both Persian and Arabic. The second language was their proverbial "window to the world." If a scholar wanted to achieve success, he had to know Arabic. Similar behaviour of the Christians of all churches was practiced. Thus, works by Christian authors written in Arabic contributed to the scientific base of Baghdad.

Christians in the current of polemics

\subsubsection{Melkite-Muslim polemics and public discussions}

The religious discussions and polemics in the 8th and 9th centuries were generated by several interactions in the context of the Islamization of the Abbasid caliphate. First, they were a defensive reaction of Christians and an attempt to present Christianity, which they deeply believed to be right. Second, Muslim theology stressed Islam's absolute monotheism and perceived Christianity as a perverted form of monotheism due to the Trinitarian doctrine of God. Moreover, the Christological differences between the Churches were used against Christianity by some Muslim polemicists such as Abū 'Īsa al-Warrāq, who died in 861 (Warrāq 1992). Thirdly, the exchange of opinions was sometimes supported by the caliphs themselves who were concerned about the unity of the state (Capezzone 1998: 1-62).

The spirit of polemics with Islam extended to all Churches of the Middle East. The "Nestorians" had the famous Timothy I of Seleucia-Ctesiphon (780-823), the patriarch of the Church of the East from 780 to 823 (Thomas, Roggema 2009: 515), and Abū Ya 'qūb bin Isḥāq al-Kind (c. 800-873). Georg Graf (1875-1955), however, lists dozens of polemicists among the "Nestorians," "Jacobites" and Copts (Graf 1947: 103-219).

The position of the Melkites was essentially linked to Byzantium's long conflict with the Islamic world, where war and religion intertwined as concepts and ways of life for both Muslims and Christians. This is how a sense of inevitable and even necessary mutual exclusion arose throughout history. Thus, a parallel syndrome emerged on both sides: the desire to replace the Christian Byzantium with an Arab Islamic identity, and on the Byzantine side, the "reconquest" and reconstruction of 
the Christian order in the lands conquered by Muslims (Sahas 2013: 397).

It was mentioned that the religious mosaic of the caliphate provoked the caliph to organize intra-religious discussions in Baghdad. Even if they did not remove all prejudices, at least representatives of different religions and their denominations were invited to present, justify, and defend their beliefs. In the 10th century, Baghdad was a unique forum where representatives of various schools could learn the beliefs of others first-hand. Muḥammad b. Abī al-Nașr alHumaydī (11th century) in his biographical dictionary of rulers, scholars and poets Ğadwat al-muqtabis $f \grave{\imath}$ ta'rīh 'ulamä' al-Andalus ["Firebrand for the Seeker of Illumination about the Scholars of al Andalus"] recounted the experiences of one of the participants of such a meeting, which, due to its peculiarity, should be quoted more extensively:

I found that the first gathering I attended had brought together all the groups-Muslims, both Sunnis and heretics, unbelievers including Magians, atheists, infidels, Jews, Christians, and all other varieties of unbelievers. Each group had a leader who spoke and debated on behalf of his sect. And if the leader of any group entered, everybody stood up and remained standing until he had sat down, after which they would resume their seats. When the place was full and they saw that they were not waiting for anyone else to turn up, one of the unbelievers said: "You are now gathered together for the debate, and the Muslims will not be arguing against us on the basis of their Book or the words of their Prophet, since we do not believe in it or endorse it. Rather, our debate will rely upon intellectual arguments and such as can be sustained by rational opinion and analogy." They replied "Yes. We grant you that."/.../ So when I heard that, I did not return to that gathering. (English translation: Salimi 2014).

Also, Abu al-Ḥasan 'Alī b. al-Ḥusain al-Mas' ūdī (c. 896-957), in his Kitāb at-tanbīh wa l-išr $\bar{a} f$, mentions that he met with a certain "monophysical" scholar to discuss the Holy Trinity (Maçoudi 1896: 212). These kinds of discussions took place in the presence of the prince or the first minister. They gathered scientists representing various positions on this dogma. The participants represented not only particular religious communities but, surprisingly, also various professions: among them there were philosophers, theologians, doctors, artists, and poets. Inter-religious and inter-confessional discussions were particularly sensitive. They were most often conducted in four areas: apology, polemics, counter-versions, and the analysis of dogmatic issues. Some of the items for discussion were prepared in writing. Usually, a predetermined plan of the topics was used. Not necessarily every point of discussion had to be exhausted; in case of 
Theodore Abū Qurra (c. 750-830): first Melkite polemics in Arabic protracted controversy, the participants moved to the next issue (Nasrallah, Haddad 1979: 96-97).

Undoubtedly, one of the most outstanding Melkite intellectuals of the early Middle Ages was the bishop of Harrān, Theodore Abū Qurra (c. 740-820). He was born in Edessa, where he received his education. Then he entered the monastery of St Saba in Palestine. It is also believed that he studied the Qur'ān in Baghdad. In 813, he became bishop of Harrān, but soon after taking office, he returned to the monastery. Between 813 and 817, he stayed in Armenia, debating with the "Monophysites" at the court of Ashot IV Bagratuni (died 826). In 814 , he travelled to Alexandria. During this visit, he stayed at the monastery of St Catherine in Sinai, where he created a work entitled "Book of Master and Disciple," which has been lately attributed to "Thaddeus of Edessa" (Treiger 2016: 1-51; Lamoreaux 2009: 408). Due to the wide interest of Abū Qurra and the fact that he was the first Melkite author after the Arab conquests who wrote in Arabic (Theodore Abu Qurra 2014: 60-89; Théodore Abuqurra 1986), the bishop of Harrān received a vast number of studies (e.g. Dīk 1999; Dick 1962: 209-223, 319-332; Khoury 1969b: 83-105; Guillaume 1925: 42-51; Hammerschmidt 1955: 147-154; Akinian 1922: 192-205; Beck 1959: 488-489; Graf 1947: 2: 7-26; Griffith 1979; 1985: 53-73; Nasry 2007: 285-290; Monferrer Sala 2005: 41-56; Erismann 2014: 39-59).

Theodore carried out a wide-ranging, high-level apologetic and polemical activity. He discussed with the Jews, Muslims, and "Monophysites" from Armenia (he invited the latter to join the Melkite Church). His 43 treatises in Greek (the authenticity of some of them is questioned, Theodorus Abucura PG 97, 1446-1610) and 12 in Arabic have been preserved. The works written in Syrian (30 in total) have unfortunately been lost. Abū Qurra was strongly influenced by St John of Damascus and the theologian Leontius of Byzantium (485-543).

While analysing the works of Theodore devoted to Islam, it is easy to identify several themes of his polemical argument. First, Abū Qurra tries to show the uniqueness of Christianity by comparing the way of propagating the Gospel with the way of promoting Islam. Those who first preached Christianity did not offer potential converts the promises of earthly prosperity, but only hardship and humility. Second, Theodore zealously defends and justifies Christian doctrines and practices, while focussing on the most controversial topic for Muslims, that is, the reality of the Holy Trinity. Equally important for Bishop Harran was the defence and justification of other dogmatic areas, such as the issues of free will and the Christian understanding of salvation (i.e. the value of Christ's redemptive work). In turn, the defence of Christian practices focussed on the sacraments of 
baptism and the Eucharist as well as on the justification of worship of the icon and the cross. Theodore's Arabic writings are full of tactful euphemisms, rarely mentioning Islam directly. He uses descriptive synonyms such as "those who claim to believe" or "those who claim to have a book sent by God." (Theodore Abu Qurra 2014: 60-89; Lamoreaux 2009: 408-416; Khoury 1969a: 83-105; Guillaume 1925, 42-51; Khoury 1982: 15-140; Pizzo 1998, 667-676; Griffith 1987: 79-108; 1993: 143-170; 1999b: 203-233; Nassif 2005: 333-340).

In the 8th and 9th centuries, there emerged many anonymous works in the genre of historical fiction or hagiographic stories that spread the critique of Islam. Criticizing Islam in the Muslim world has always been a delicate and dangerous topic. According to the Pact of 'Umar, Christians were strictly forbidden to question any aspect of Islam. It has already been mentioned that many Muslim authors believed that failure to follow even one prohibition of this Pact by a dimmi ("protected person") resulted in the automatic recognition of a disobedient Christian as a rebel who had broken the contract. It was even punishable by death. Therefore, many authors chose a less "honourable" way of expressing their thoughts and opposition to Islam by publishing anonymously (Nasrallah, Haddad 1979: 99).

The polemical arguments of St John of Damascus and Theodore Abū Qurra were largely adopted and replicated in Byzantine polemical literature with Islam. Nevertheless, in Byzantium, Islam was sometimes criticized much more boldly and radically than in the Muslim world. For this reason, every so often, Byzantine polemics used a lot of sarcasm and insults. For example, according to Theophanes, Islam was so untrue that even the Jews, "blasphemers" themselves, refused to acknowledge it (Theophanes 1885: 208-211). Daniel Sahas rightly calls this ambivalent pragmatics of substantive polemics (Theophanes did not just have a negative vision of Islam!), alternating with invectives, "the art and non-art of Byzantine polemics" (Sahas 1990: 55-73).

Amid the polemics, the most substantive argument (i.e. the deity of Jesus, who is the essence and originality of Christianity for Christians) was not always exposed in the first place. Byzantine polemics more than once emphasized too many secondary aspects. Islam was mainly criticized for Muhammad, who was considered a false prophet with an immoral lifestyle. The Byzantine polemical text presented Muhammad's life in sharp contrast to the ascetic model of the saints (Nikolaou 2017). Moreover, Theophanes, as the first among the Byzantines, argued that Muhammad suffered from epilepsy (Cecota 2012: 99). Then, the authenticity and value of the Qur'ān were questioned: it was accused of promoting a distorted image of God. Muslim practices such as polygamy, the practice of

Melkite criticism and Byzantine polemics against Islam 
divorce, which favoured adultery, holy war, prohibitions on eating certain foods, etc. were vehemently rejected. Finally, anthropological notions of a paradise full of houris and material goods were questioned. The Qur'ān was considered merely a collection of fairy tales (Anonymous 2014: 40-59; Khoury 1969; 1982: 30-100). In some points, Byzantine apologetics followed early Melkite thought (e.g. of the Melkite patriarch of Jerusalem Sophronius from the 7th century). Christians angered God by succumbing to various heresies such as "Monophysitism," Monotheletism and iconoclasm. Muslim Arabs have become an instrument of punishment. Hence, Islam is successful, but this does not mean that this religion in itself is superior to Christianity. In the future, after the purification of Christianity, the Church will triumph (Dagron 1999b: 200).

The Melkites in polemical propaganda during the Byzantine-Arab wars

Polemics in the form of an exchange of correspondence
Islam systematically began to affect the mentality of the Byzantines. The rapid advances of Islam shocked them immensely as they had believed for centuries that their empire was protected by God (Nikolaou 2017). During the long Byzantine-Arab wars it happened that before the battles each side in the conflict sent appeals or invectives to the enemy. Sometimes Muslims, following the example of Muhammad, sent letters before decisive battles to the rulers or commanders of the enemy's troops, encouraging them to accept Islam.

In turn, the Byzantines wrote appeals and invectives to the Muslim side. More than once they had a literary form and were written in Arabic so that they could be well understood by the caliph's soldiers. Such texts were written in Greek less frequently. There must have been some Melkites in the service of the Byzantine emperor who knew both Arabic and Greek. Of course, this is only an assumption about the authorship of such anonymous proclamations. The authors of these texts were likely not the Arabic-speaking Christians of the heterodox Eastern Churches such as the "Nestorians," "Jacobites," and Copts, since they were traditionally hostile to Constantinople. Therefore, it is believed that the authors of these proclamations and invectives during the campaign were Melkites who knew Arabic (Nasrallah, Haddad 1979: 100).

The differences between Christianity and Islam were not always exposed in the tone of aggressive polemics or invectives. There were also specific polemics in the form of correspondence, which were an exchange of views stated as a more positive presentation of one's standpoint. The topos of correspondence was a special method for developing arguments. In this kind of text, both sides raised objections and questions, often referring to logic. They encouraged the adoption of - in the opinion of the authors - true religion, and awaited a factual response. The topos of correspondence used the names of the rulers to enhance the value of a particular debate. It is 
obvious that the real authors of this polemical correspondence were not the rulers mentioned in the titles of the letters. These are drafts of apologetics, not personal letters (Gaudel 1984: 116).

A good example of such polemics was a peculiar exchange of texts in Arabic, assigned symbolically to the Byzantine emperor Nikephoros II Phocas (963-969) and to Caliph al-Muțī (946-974). On the Muslim side, the answer was written by the shāi lawyer Ismā'īl al-Qaffāl al-Kabīr aš-Šāšī (died 976). The text which provoked the "correspondence" reactions was created in the context of the "Byzantine Reconquista" and the attempts at Christianization of Muslims who find themselves in a difficult situation. The Arabic poem attributed to Nikephoros Phocas contains a clear declaration of spreading Christianity among Muslims. The answer to this text can be found in a poem by the above-mentioned theologian al-Qaffāl al-Kabīr aš-Šāšì (Ramaḍān 2019: 286).

Another well-known example of the topos of correspondence is the discussions contained in the texts attributed to the Umayyad caliph 'Umar II (717-720) and the Byzantine emperor Leo III (717-741). It is worth adding that the research on this correspondence has brought many interesting findings and hypotheses. Scholars are intrigued by the identity of the real authors of the polemic. The Muslim author who is unknown to us and hides under the pseudonym 'Umar II, most likely lived in a Melkite Christian community because he quoted St Basil the Great (330-379) and St John Chrysostom (c. 350-407), having translated their Greek names into Arabic. In addition, he was familiar with the cult of relics and Christian practices and he faithfully quoted Christian scriptures. The author of 'Umar II's letter could have been a Christian prisoner or a merchant. On the other hand, the Christian author hiding under the pseudonym of Leo III probably did not live in the lands of Islam: he quotes the Qur'ān sparsely and even makes some mistakes regarding Islamic practices. He does not seem to be involved in politics: perhaps he was a Byzantine monk (Gaudel 1984: 35-78; Sourdel 1966: 1-33; Jeffery 1944: 269-332; Kościelniak 2002b: 97-105).

Muslim relations with the Melkites in the context of Byzantine diplomatic efforts in the early Middle Ages were not only a series of conflicts and polemics. For example, in Cyprus, the agreement signed by Emperor Justinian II (685-695) in 688 introduced the coexistence of Christians and Muslims, unhampered access to ports for both sides and equal distribution of taxes (Theophanes 1885: 30). Geographically isolated from the direct influence of Constantinople and the caliphate capitals, Cyprus was a specific "buffer zone" between the two powers. A detailed study of the archaeological material (seals, coins, ceramics, and material artifacts) shows that this peaceful coexistence, initiated under the Umayyads, survived the

The opposite pole: peaceful coexistence, diplomacy and gestures of friendship 
following centuries. Moreover, Cyprus remained a kind of a bridge between the Christian and the Muslim worlds. Although it was always a disputed island, it paradoxically provided a peaceful space for pilgrims, diplomats, and merchants. Two separate communities, however, quite effectively sustained the cultural, political, and economic coherence of the whole island (Zavagno 2013: 1-21; Hill 1940: 284-290; Kyrris 1984: 149-175).

In diplomatic correspondence, especially when one of the parties was keenly interested in a compromise, the tone of insult was put aside. As a result of the Arab attack on Thessaloniki, many Greeks were taken prisoner by the Muslims. In July 904, the patriarch of Constantinople, Nicolas the Mysticus (901-907; 912-925), wrote to the Muslim ruler, probably the emir of Crete, Muhammad b. Šu ayb (895-910), asking for an exchange of prisoners. Although the abductees were never identified, it appears they came from Thessaloniki. The patriarch, however, referred to the "deep friendship" between Photios I of Constantinople (858-867 and 877-886) and his correspondent's father (Nicholas I 1973: 2-16). Emphasizing the great friendship between these political entities was certainly exaggerated and focussed on achieving success in the negotiations. Nevertheless, this is the first time that correspondence recognizes fully both the Byzantine Empire and the Caliphate as the supreme powers. This recognition of the legality of the Abbasid state is a clear modification from the traditional approach of Constantinople, which perceived Basileus as the sole ruler (Drocourt 2010: 32-33).

The very polite tone of diplomatic correspondence also dominated the letter of the same patriarch to the Abbasid caliph Abū al-Faḍl alMuqtadir (908-929/932). It concerned the breached neutrality of Cyprus, which, as mentioned, had been maintained for the benefit of both sides since 688 . The problems were generated externally by Damyānah al-Ṭarsūsì (died 924), the Christian apostate and Tulunid partisan, who murdered or captured many Christians in Cyprus between 911 and 912. At the same time, he went to the caliph with a request to release the deported St Demetrian, bishop of Chytria (died 915). As for the letters, the arguments of Nicolas the Mysticus are interesting. First, he assured that Muslim prisoners of war were treated well in Byzantium. Second, the patriarch wrote that all power comes from God, and, therefore, both the Byzantine emperor and the caliph should communicate as brothers for the benefit of the people (Nicholas I Patriarch of Constantinople 1973: 2; Vita Demetriani 1907: 232-233; Drocourt 2010: 32-33; Vasiliev 1968: 399-411; Dagron 1999b: 202-203; Jenkins 1949: 268-275; 1962: 229-241). 


\section{Conclusions}

Although the Melkite Patriarchates were created long before the Arab conquest of Syria and Egypt, between 634 and 969, there was a profound transformation of these communities, which contributed to the creation and consolidation of a specific church identity. This identity was not shaped by the direct influence of Constantinople or Rome, though it did emerge in the context of interactions with Byzantium and, to a much lesser extent, with the Church of the West. Of course, the Melkite communities grew up, to some extent, in the cultural climate of Byzantine orthodoxy, although they retained their distinctiveness and by no means followed all Greek theological concepts and currents.

Paradoxically, the long-term condition of the Melkite Church in the lands controlled by Muslims from 634 to 969 was connected with the "starting point," that is, the condition of individual Melkite Patriarchates in 634. It is absolutely necessary to consider the consequences of the turbulent era of Christological disputes and inter-confessional conflicts for these communities. The Arab campaigns in Syria and Egypt quickly resulted in the inclusion of all three Melkite Patriarchates into the young Muslim state (up to 641). In the next decades, the heritage of the Christological controversy, the double (and even triple in some regions) Christian hierarchy was overlapped by new cultural and religious processes of Arabization and Islamization. For the Melkites, there was a period of profound demographic and cultural transformation, the consequences of which are felt to this day. The Melkite Church underwent a process of gradual marginalization, that is, from the privileged position of the state confession to one of the religious minorities of the Caliphate. All of this took place in the context of theological and political interactions with the Byzantine Empire, the patriarchate of Constantinople, the papacy, and, over time, with the reborn Roman Empire in the West. 


\section{1 "The Starting Point" 634-the legacy of controversy}

At the time of the first interaction with Arab Muslims, the condition of the Melkite communities was dependent on the degree of their conflict with "Monophysites" and the consequences of earlier inter-confessional conflicts. The key factor for the condition of individual Melkite Patriarchates was the number of supporters of the Chalcedonian option. The patriarchate of Jerusalem, where "Monophysitism" and Monotheletism did not take root deeply and a decisive and relatively stable advantage of the Chalcedonian Orthodoxy was built. Nearly 100 per cent of Palestinian Christians belonged to the Melkite Church. The confessional situation in the patriarchate of Antioch was much more unfavourable for the Melkites, as the Christians were divided almost equally there: into those in favour of the Melkites and of "Jacobites." The cities were generally dominated by Melkite Greeks, while the Aramaic (Syriac) village was a strong base of "Monophysitism." Finally, the most disadvantageous situation for the Melkites was the condition of the patriarchate of Alexandria, in which as many as $90 \%$ of Christians supported Coptic "Monophysitism."

\subsection{The early Islamic state and Umayyad period of Melkite-Muslim interaction, 634-750}

Umayyads gradually, albeit relatively slowly, marginalized the position of the Melkites in the Muslim state. It was not a linear and homogeneous process. The different contexts of the rapid Muslim conquests of individual patriarchates in 634-641 generated different types of Melkite-Arab interactions. Thus, the Melkites of the patriarchate of Antioch provided "models" of Christian-Muslim treaties in general. In Egypt, contrary to widespread opinions about the favouring of the Copts by the victorious Arabs, Muslims treated both communities equally, and many factors that influenced the degradation of the Melkite Church were a consequence of the errors of Byzantine policy in Egypt before the Arab conquests. Finally, the patriarchate of Jerusalem suffered destruction in the villages, but contrary to some opinions, archaeological research has not confirmed the destruction of the Melkite Churches in Jerusalem. The conquest in 638 did not rapidly change the status of Christians in this city. It can be said that plundering - by no means religiously motivated-affected some churches and monasteries outside urban centres.

With the reign of the Umayyads (661-750), new Melkite-Muslim interactions gradually intensified. First, Muslim lawyers systematically 
specified the scope of restrictions, obligations and rights of Christians, which was finally reflected in the apocryphal Pact of 'Umar. Second, from a political point of view, the Melkites understood that Muslim power had become an accomplished fact in territories historically associated with their patriarchates. The Melkites were not only cut off from Constantinople, which traditionally supported Orthodoxy, but were also suspected of conspiring with the Byzantines, especially during the Byzantine-Arab wars. Over time, new restrictions began to apply and even periodic persecution of the Melkites occurred during the reign of 'Abd al-Malik b. Marwān (685-705), al-Walīd I (705-715), Sulaymān (715-717), 'Umar II (717-720), and Yazīd II (720-724).

These Umayyad interactions started "decades of ambivalence": the decades in which the peaceful acculturation of the Melkites was interrupted by pernicious legal actions or persecution (in the Muslim world "decades of ambivalence" practically repeated over the centuries). The periods of peaceful acculturation coincided with the reluctance of some Muslims towards the Melkites, or even their persecutions. During the reign of this dynasty, there were many examples of peaceful coexistence between Melkites and Muslims. On the other hand, a long vacancy on the patriarchal thrones, or the takeover of St John's Basilica in Damascus testify to the atmosphere of distrust and aversion felt by some Muslim rulers and administrators towards the Melkites. At the turn of the 7th and 8th centuries, the patriarchates of Antioch, Alexandria, and Jerusalem did not have patriarchs (Antioch from the death of George II c. from 702 to 742; Alexandria from the death of Peter III from 651 to 742 and Jerusalem from the death of John V from 735 to 752 ). Some patriarchs sometimes met with a tragic fate: Stephen III (742-744), patriarch of Antioch, whose statements did not please the caliph, had his tongue cut out by order of Al-Walīd II b. Yazīd (743-744). In general, the Pact of 'Umar-on the condition of accepting the limitations - guaranteed Christians freedom of religion and worship. However, the Muslims did not always respect these guarantees. For example, during the rule of 'Abd al-Malik b. Marwān (685-705), the Melkites from the Tagilibits clan were forcibly converted to Islam.

The Melkite Church revived its structures during the reign of Caliph Al-Hišām b. 'Abd al-Malik (724-743), who abolished many anti-Christian of the laws issued by his predecessors. Apparently, in the privacy of his palace, he liked to listen to prayers and Christian readings. The atmosphere of respect and tolerance during this period is confirmed by the example of Hālid b. 'Abdallāh al-Qasrī (died 743/744), the Umayyad ruler of Mecca and Iraq, who built a church for his Melkite mother (rümiya) directly behind the mosque in Kufa. 
Apart from the actions of the new authorities, which affected all the Melkite communities, each of the patriarchates had their own particular, local experiences. Each of them also made a different contribution to the universal Church. The patriarchate of Antioch experienced tangible conflicts because its north-western border coincided at certain times with the Byzantine border with the caliphate. The great particular failure of the Melkite community of Antioch was the aforementioned loss of the basilica of St John the Baptist during the reign of Al-Walīd I. During the polemics in the first phase of iconoclasm, St John of Damascus wrote a treatise justifying the cult of images, which still remains one of the best approaches to this issue in Orthodox and Catholic theology.

In turn, the patriarchate of Alexandria did not have a patriarch residing in Egypt until 727 (the titular patriarchs of Alexandria stayed in Constantinople). In a situation of painful histories, one of the last attempts at reconciliation between the Melkite and Coptic communities was made by the Melkite patriarch Cosmas (727 [731?] -768), who had been highly respected by the Copts. The Melkites, until 750 , continued their scientific activities to a small extent. Nevertheless, the works of John Philoponus (c. 490-c. 570) were disseminated (he was known among Arabs as Yahyā al-Naḥawī). Basically, iconoclasm was an external problem in this patriarchate.

Jerusalem retained its Christian character, although the foundation of the mosque was intended to compete with the Melkite Churches. Caliph 'Abd al-Malik b. Marwān ordered the construction of a new mosque dome to compete with the magnificent Church of the Resurrection. This was an element in the process of consolidating Muslim claims to Jerusalem as the Holy City of Islam. In turn, during the Arab-Byzantine wars, Jerusalem strengthened its role in this theological/political dispute, while attempting to revive the papacy. Seeing the waning influences of the Byzantine Empire, the Melkites from Jerusalem complained in Rome to Pope Theodore I (642-649). The very career of this Melkite pope shows the complexity of East-West interactions in the 7th century. Theodore was, according to Liber Pontificalis, the son of the Melkite bishop of Jerusalem and probably came to Rome as a fugitive from the Muslim invasion. The financial support of the Melkites by Pope Martin I is also a known fact. The West pilgrimage movement was developing, as evidenced by Arculf, bishop of Périgueux, who spent several months in Jerusalem. Iconoclasm met with disapproval in this patriarchate, although not necessarily all Melkites accepted the cult of icons with great enthusiasm.

The Melkites who lived outside the classical borders of the Melkite Patriarchates deserve special attention. The genesis of the Melkite communities in the east provinces of caliphate (in Iraq and Central Asia today) goes back to the times of the deportations of 
Melkites during the Sasanian period. Later, the Greek prisoners of the Byzantine-Arab war caused their number to increase. The mysterious Catholicate Rumagyris and Melkite presence in the Central Asia extended the influence of patriarchate of Antioch to the new territories.

\subsection{The Melkite Patriarchates in the Abbasid caliphate, 750-969}

The Abbasid period was full of "decades of ambivalence." It is true that these most extreme actions were taken in dramatic political contexts of integration or disintegration of the caliphate. This is evidenced by the cases of some Melkite patriarchs. Patriarch Theodoretus (before 787-[?]) was accused of conspiring with the Byzantines and was therefore exiled to Moab in 787. Job (813/ 814-844/845) had to crown not only a Byzantine rebel traitor, but also, by order of the caliph in 838 , was forced to cooperate with Muslim forces during the siege of Amorion, for which he was stoned to death by the inhabitants of that fortress. The Melkite patriarch of Antioch, Christopher (960-967), was killed in 967, although he was a loyal citizen of the Hamdanid prince Sayfa ad-Dawla. In Jerusalem in 966, Patriarch John VII was murdered during a riot supported by the governor. His body was tied to a pillar in the narthex of Constantine's Church and burnt. The plight of Christians was aggravated by the excessive fiscalism of the Muslim state, which fuelled the machinery of Islamization.

The persecution took many forms. The first wave came during the reign of al-Manșūr (754-775). The escalation fell on the rule of alMa'mūn (813-833), to take the most severe forms during the reign of Al-Mutawakkil, who was a supporter of the restoration of strict Islamic orthodoxy. The atmosphere of those years is reflected in the famous quote by Mārī b. Sulāymān (13th century) "[Christian] children should not go to Arab schools!"

If the Melkites managed to adapt better or worse to the conditions of the Muslim state and to survive periods of legal rigour and persecution, they did so thanks to their cleverness and tolerant politics of some caliphs or governors, whose attitude contradicted the ordinances of the rulers who repressed Christians. In the calmer years of the Abbasid reign, the Melkites took an active part in political and cultural life. The Caliph's Palace was often open to both Christian and Muslim poets. Especially the period of the influential Iranian Barmakid family (750-803) in Baghdad or the short-lived reign of the Tulunids (868-905) were beneficial to the Melkites.

The Abbasid period was also a time of extraordinary inter-religious discussions which-according to descriptions of Muhammad b. Abī 
al-Nașr al-Humaydī - were conducted in representative groups, with high level of argumentation and with excellent logistics of the organizers. It is also interesting that Melkite monasteries during this period attracted some Muslim rulers who willingly visited them. The lives of simple people often exceeded confessional barriers. It happened that both Christians and Muslims participated in Christian rites (Kilpatrick 2003: 24-25). Until the 2nd century of the Hijri calendar, Christian writers placed the sign of the cross on the dorso (i.e. on the reverse side) of official documents, as evidenced by bilingual texts from Egypt.

During Abbasid period, there was also an exchange of knowledge between Christians and Muslims. Acculturation processes were steadily gaining momentum until the 10th century. Christians were the teachers of Muslims and vice versa.

Regarding external relations, there was a kind of "anti-iconoclastic front," which included the papacy and all three Melkite patriarchs. Their activities contributed to the end of the first phase of iconoclasm in 787. All three Melkite patriarchs were also a supporting voice in the dispute between Photios and papacy and during the recognition process of the fourth marriage of Emperor Leo VI.

The interactions between the Melkite communities deserve special attention. It was also customary to refer to the opinion of all three patriarchs when problems appeared in a particular Melkite community in the Muslim world. This was the case with the famous dispute between the patriarch of Antioch, Simeon (890-907) and David, the metropolitan bishop of Damascus (890-891).

Looking at the condition of the various patriarchates in 750-969, there was a great variety of interactions. In the 9th century in Antioch, there was a tendency among the Melkites to appeal to Muslim authorities to settle intra-church disputes.

The monastic life in the patriarchate of Antioch was primarily concentrated in the Monastery of Saint Simeon Stylites. This patriarchate also had a strong intellectual elite who was represented by eminent intellectuals, such as the historian Maḥbūb b. Qunsțanținn al-Mambiğ $\overline{1}$ (died 945); the famous physician, philosopher, astronomer, mathematician, and translator Qusțā b. Lūqā al-Ba labakkī (820-912); the patriarch of Antioch, Job (813/814-844/845), who collaborated with the "Nestorian" catholicos; Timothy I of SeleuciaCtesiphon (780-823) in the translation of Aristotle's Topics; and finally the outstanding polemicist with Islam, bishop of Ḥarrān, Theodore Abū Qurra (c. 740-820).

The patriarchate of Alexandria experienced further social marginalization and a reduction in the ownership of temples. It did not even maintain the status that had been established in the first decades after the Arab conquests, when the Melkites lost many temples to the Copts. Nevertheless, the opinion that the Melkite patriarchate of 
Alexandria in the early Middle Ages was a "forgotten bishopric" is not entirely true, at least because of the importance of the title of the ancient apostolic see. On behalf of the patriarch of Alexandria, representatives of this patriarchy appeared in almost all major assemblies of bishops. This demographically small patriarchy was not, however, affected by intellectual erosion. Such patriarchs as Politianos (768-813), Christopher (817-841 [848]) and especially Patriarch Eutychius of Alexandria were among the greatest Melkite intellectuals of this period. Especially, Sa ${ }^{\prime} \bar{d}$ b. Bițriq has left us a history that is an invaluable source on the Melkite Church in the early Middle Ages. In this patriarchate, there was only one Melkite monastery in al-Qușayr.

The territorially small patriarchate of Jerusalem also tried to maintain its importance as the guardian of places which are holy for all Christians. Since the beginning of the 9th century, the Melkites had been located at a particular crossroads between the two "Roman Emperors," the caliphate and the papacy. The new chapter in the relationship of the West with the caliphate is vigorously discussed and critically studied by historians. Regardless of the understanding of the intriguing passage from Einhard's chronicles about the caliph handing over the authority of the holy places to Charlemagne, the fact is that the new emperor of the West provided support to the Melkites in Jerusalem and financed several projects there. This situation also led to further contact between the Melkite Patriarch of Jerusalem and Charlemagne and the papacy. As for monastic life, despite serious damage, for example, to the monastery of Mār Sābā, it was still alive and took place in several religious sites, including the monastery of St Catherine in Sinai, Mār Sābā, and St Chariton.

On the other hand, the Melkite communities east of the Euphrates lived to see the establishment of the Melkite bishopric in Baghdad after many vicissitudes of fortune. In this way, two Catholicates were formed: one in what is now Iraq (in Baghdad) and the other for Central Asia (in Tashkent). However, it is highly debatable how much missionary activity there was among the Melkites.

In the time period under study, Melkite monastic life experienced many disasters and tribulations. Nevertheless - to a varying degree, depending on the century - the monasteries remained refuges of the Melkite culture and identity.

All these "decades of ambivalence" ultimately contributed to the gradual weakening, and, in some regions, even to the fall of the Melkite Church. First of all, the number of Melkites was systematically decreasing due to Islamization. Today it is almost impossible 


\section{Conclusions}

to recreate the process of Islamization in the Middle East. Based on more or less probable sources, it is assumed that at the beginning of the 9th century Christians constituted the majority (at least in large areas of the Middle East), but in the 10th century, there were no more than $20 \%$ of them. The Melkites, who dominated the cities of Syria and Palestine in the 7th century, constituted an overwhelming minority at the end of the 11th century. From a cultural point of view, the Melkite Church was being systematically Arabized. Greek disappeared as a spoken language and survived only in the liturgy. From the end of the 8th century, Arabic increasingly dominated Christian writings, which consisted of translations from Greek and Syrian, as well as apologetic and theological treatises mainly on the Islamic-Christian dispute. Although the period from 634 to 969 cannot be absolutely considered as the time of intellectual erosion of Melkite communities, the potential of Melkite Patriarchates before the Arab conquests was a thing of the past.

Nevertheless, the cultural dynamics of religious interactions in this period ultimately determined the new, unique nature of the Melkite Patriarchates. They became representatives of the Arab orthodoxy par excellence which, despite the influences of Hellenization trends, could not already be reduced to a simple continuation of Greek or Aramaic Orthodoxy. 


\section{List of Melkite patriarchs, 634-969}

\subsection{Patriarchs of Antioch}

sede vacante

Macedonius

George I

Macarius

Theophanes

Thomas

George II

sede vacante

Stephen III or IV

Theophylact b. Qānbara

Theodore I of Antioch

Theodoretus

Job

Nicolas I

Stephen IV (?)

Theodosius I

Simeon I

Elias I

Theodosius II

Theocharistus

Agapius I

Christopher

Eustratius
609-639

639/640-649 (?) 662 (?)

(?)-(?) presumably 662-669

(?)-681 presumably 669-681

681-(?) presumably 681-684

(?)-685 (?) or Sebastian (687-690)

685 (?)-702 (?) presumably 691-702

702 (?)-742 (743?)

$742 / 743-744 / 745$ presumably $743-744$

$744-750$

750/751-773/774

before 787-(?) or 781-812 (?)

$813 / 814-844 / 845$

$847-867$ or $846-868$ (?)

870 (one day pontificate [?])

$870-890$

890-907

907-934

936-943

944-948

Agapius b. Qa barūn (953-959?) or (?)-(?) (960-967)

(969) 


\subsection{Patriarchs of Alexandria}

\begin{tabular}{ll}
$\begin{array}{l}\text { Cyrus } \\
\text { Peter III=Peter } \\
\quad \text { IV [?] }\end{array}$ & 630 or $631-632$ \\
sede vacante & 651-727 (questionable pontificates in Constantinople [?]: \\
& Theodore II; Peter IV=Peter V; Peter V = Peter VI; \\
& Theophylact; Onopsus \\
Cosmas I & 727 [731?] or 742-768 \\
Politianos & $768-813$ \\
Eustatius & $813-817$ \\
Christopher & $817-841(848 ?)$ \\
Sophronius I & $841-860(848-860 ?)$ \\
Michael I & $860-870$ \\
Michael II & $870-903$ \\
Sede vacante & $903-907$ \\
Christodulos & $907-932$ \\
Eutychius of & $933-940$ \\
$\quad$ Alexandria & \\
Sophronius II & 941 \\
Isaac & $941-954$ \\
Job & $954-960$ \\
sede vacante & $960-963$ \\
Elias I & $963-1000$ \\
\hline
\end{tabular}

\subsection{Patriarchs of Jerusalem}

\begin{tabular}{|c|c|}
\hline Sophronius I & $633 / 634-638$ \\
\hline sede vacante & $\begin{array}{l}\text { 638-693 [?] - Patriarchal Vicar John of Philadelphia } \\
\text { (d.649?) and Stephen of Dora (after 649-?), }\end{array}$ \\
\hline Anastasius II & $681 / 693[?]-705[706 ?]$ \\
\hline John V & $705[706]-735$ \\
\hline sede vacante [?] & $735-745$ [752?] John VI [?] \\
\hline & John V= John VI [?] \\
\hline Theodore I & $745[752 ?]-770$ \\
\hline sede vacante [?] & $735-752$ \\
\hline Theodore I & $752-767$ or $745-770$ \\
\hline Elias II & $770-797$ or $787-797(?)$ \\
\hline $\begin{array}{l}\text { [Theodore } \\
\text { Intruder] }\end{array}$ & $(?)-(?)$ \\
\hline George & $797-807$ or $(?)-807$ \\
\hline Thomas I & $807-820$ or $808-821$ \\
\hline Basileus & $820-838$ or $821-839$ \\
\hline
\end{tabular}


John VI 839-843 or 838-842

Sergius I $\quad 842-844$ or $843-859$ (?)

Sede vacante $\quad 844-855$ (?)

Salomon $\quad 855-865$ or $860-865$ (?)

Theodosius $\quad 862-878$ or before $867-878$ (?)

Elias III $\quad 878-907$

Sergius II $\quad 908-911$ or $907-911$

Leontius I 912-929

Athanasius I 929-937

Christodulos I 937-951 or 937-950 (?)

Agathon $\quad 951-964$ or 950-964 (?)

John VII 964-966

Christodulos II 966-969 


\section{Bibliography}

\section{Sources}

Abou Yousof Ya'koub. 1921. Le Livre de l'impôt foncier (Kitâb el-Kharâdj). Traduit et annoté par E. Fagnan. Paris: Geuthner.

Abū Yūsuf Ya'qūb. 1932. Abū Yūsuf Ya'qūb ibn Ibrāhīm al- Kūfī, Kitāb ar-Radd 'alā Siyar al-Awzā̄̄i. Al-Qāhira: Dār al-Kutub al-Mișrīya.

Adversus Constantinum Caballinum. 1864. Patrologiae cursus completus. Series Graeca, ed. J.-P. Migne, vol. 95: 309-344. Paris: Garnier.

Agapius. 1910. Kitab al-Unvan-Histoire universelle écrite par Agapius de Menbidj, première partie (1.1.), ed. A. Vasiliev. In Patrologia orientalis, ed. R. Graffin and F. Nau, vol. 5: 562-691. Paris: Firmin-Didot.

Agapius. 1911. Kitab al-Unvan-Histoire universelle écrite par Agapius de Menbidj, second partie (2.1.), ed. A. Vasiliev. In Patrologia orientalis, ed. R. Graffin and F. Nau, vol. 7: 459-591. Paris: Firmin-Didot.

Agapius. 1912. Kitab al-Unvan-Histoire universelle écrite par Agapius de Menbidj, second partie (2.2.), ed. A. Vasiliev, In Patrologia orientalis, ed. R. Graffin and F. Nau, vol. 8: 396-547. Paris: Firmin-Didot.

Agapius. 1915. Kitab al-Unvan-Histoire universelle écrite par Agapius de Menbidj, second partie (1.2.), ed. A. Vasiliev. In Patrologia orientalis, ed. R. Graffin and F. Nau, vol. 11: 5-144. Paris: Firmin-Didot.

al-Armanī, Abū Șālih. 1895. The Churches and Monasteries of Egypt and Some Neighbouring Countries Attributed to Abû Sâlih, the Armenian, ed. B. T. A. Evetts and A. J. Butler. Oxford: Clarendon Press.

al-Ḥakam, Ibn 'Abd. 1922. Kitāb futuh misr wa akbārahā, The History of the Conquests of Egypt, North Africa, and Spain, ed. Ch. Torrey. Yale: Yale University Press.

Alexandriae, Michael Patriarcha. 1772. Epistola: Beatissimo comministro nostro Photio patriarchae Constantinopoleos, Michael Alexandriae. In Sacrorum conciliorum nova et amplissima collectio, ed. J. D. Mansi, vol. 17: 427-434. Zatta: Florentiæ, Venetii.

Alexandrinus, Michael. 1771. Michaelis Alexandrini epistola ad Basilium imperatori. In Sacrorum conciliorum nova et amplissima collection, ed. J. D. Mansi, vol. 16: 145-147. Zatta: Florentiæ, Venetii.

Alkuin. 1895. Epistolae. In Epistolae Karolini aevi, ed. E. Dümmler, vol. 2: 1-481. Berlin: Weidmann. 
Al-Muqaddasī. 1963. "Aḥsan at-taqāsīm $\overline{\text { fi }}$ Ma'rifat al-Aqālīm” (La Meilleure répartition pour la connaissance des provinces). Damas: Beyrouth : Impr. catholique.

Anas, Mālik ibn. 1951. Muwaț̣ā'. In Al-Qāhira: Dār Ihyā' at-Turāt al- 'Arabī, ed. 'Abd al-Bāqī, vol. 1-2.

Anastasius. 1865. Anastasii, cognomento Sinaïtae, Patriarchae Antiocheni, Opera omnia, quae supersunt. In Patrologiae cursus completus. Series Graeca, ed. J.-P. Migne, vol. 89. Parisiis: Garnier.

Anastasius. 2006. Anastasii Sinaitae Quaestiones et responsiones, ed. M. Richard and S. J. Munitiz. Corpus christianorum. Series graeca 59. Turnhout: Brepols.

Annales. 1895. Annales regni Francorum inde ab a. 741 usque ad a. 829, qui dicuntur Annales Laurissenses maiores et Einhardi. In Scriptores rerum Germanicarum in usum scholarum. Ex monumentis germaniae 6, ed. G. H. Pertz and F. Kurze. Hanovre: Hahnsche Buchhandlung.

Anecdota Monophysitarum. 2001. The Correspondence of Peter Mongus, Patriarch of Alexandria, and Acacius, Patriarch of Constantinople, together with the Henoticon of the Emperor Zeno and the Rescript of the Emperor Anastasius. In The Armenian Church: Heritage and Identity, ed. F. C. Conybeare, 636-654. New York: St. Vartan Press.

A Nestorian Collection. 1972. A Nestorian Collection of Christological texts: Cambridge Univ. Library, ms. oriental 1319. Ed. L. Abramowski. Cambridge: University Press.

Anonymous. 2014. An apology for the Christian faith, ed. M. N. Swanson. In The Orthodox Church in the Arab World, 700-1700: an anthology of sources, ed. S. Noble and A. Treiger, 40-59. Ithaca: Cornell University Press.

Antiochenus, Ioannes. 1864. Joannis Antiocheni oratio de disciplina monastica et de monasteriis laicis non tradendis. In Patrologiae cursus completus. Series Graeca, ed. J.-P. Migne, vol. 132: 1117-1148. Parisiis: Garnier.

Antiochus Strategos. 1910. The capture of Jerusalem by the Persians in 614 AD, ed. F. C. Conybeare. English Historical Review 25: 502-517.

Arculfus. 1895. The Pilgrimage of Arculfus in the Holy Land (about the Year A.D. 670), ed. J. R. Macpherson. London: Palestine Pilgrims' Text Society.

Asākir, Ibn. 1959. La description de Damas d'ibn 'Asakir, ed. N. Elisséeff. Damas: Institut français de Damas.

Balādhuri. 1866. Liber expugnationis regionum, auctore Imamo Ahmed ibn Jahia ibn Djdbir al-Beladsori quem e codice Leidensi et codice Musei brittannici, ed. M. J. de Goeje. Lugduni Batavorum: Brill.

Balādhurī. 1916. The Origins of the Islamic State: Translation with Annotations Geographic and Historic Notes of the Kitāb Futūḥ al-Buldān of al-Imâm abu-l'Abbâs Aḥmad ibn-Jâbir al-Balâdhuri, ed. Ph.K. Hitti. New York: Columbia University Press.

Balādhurī. 1996. The Battle of the Yarmuk (636) and after, ed. P. K. Hitti and J. Halsall. Medieval Sourcebook: Fordham University. https:// sourcebooks.fordham.edu/source/yarmuk.asp [accessed 12.10.2020]. 


\section{Bibliography}

Balawī. 1939. Sīrat Ahmad Ibn-Ṭulun/ta'lif Abū-Muḥammad 'Abdallah Ibn-Muhammad al-Madīn̄̄ al-Balawī. In Haqqaqahā wa- 'allaqa 'alaihā, ed. M. Kurd 'Ali. Dimashq: al-Maktaba al-'Arabīya.

Bar-Hebraeus. 1874. Gregorii Barhebraei Chronicon ecclesiasticum: quod e codice musei Britannici descriptum coniuncta opera ediderunt, latinitate donarunt annotationibusque, ed. J. B. Abbeloos and T. J. Lamy, vol. 1-2. Parisiis: Maisonneuve and Lovanii: Peeters.

Bar-Hebraeus. 1890. Gregorii Barhebraei Chronicon Syriacum, ed. P. Bedjan. Parisiis: Maisonneuve.

Barthold, V. V. 1935. 12 Vorlesungen über die Geschichte der Türken Mittelasiens. Berlin: Deutsche Ges. f. Islamkunde.

Bernardus Monachus. 1852. Bernardi itinerarium. Factum in loca sancta anno DCCCLXX. In Patrologiae cursus completus. Series Latina, ed. J.-P. Migne, vol. 121: 569-582. Parisiis: Garnier.

Bibliotheca Hagiographica Graeca. 1957. Subsidia Hagiographica 8a, ed. F. Halkin. Bruxelles: Société des Bollandistes.

Cerularius, Michael. 1864. Michaelis sanctissimi archiepiscopi Constantinoplis /.../ Cerularii, ad Petrum sanctissimum patriarchum Theopolis magnae Antiochiae. In Patrologiae cursus completus. Series Graeca, ed. J.-P. Migne, vol. 120: 781-796. Parisiis: Garnier.

Chuonradus Constantiensis. 1841. Vita sancti Chuonradi Constantiensis episcopi. In Monumenta Germaniae Historica Scriptores 4: Annales, chronica et historiae aevi Carolini et Saxonici, ed. G. H. Pertz, 429-445. Hanovre: Hahn.

Concilium Constantinopolitanum III. 1765a. Actio nona. In Sacrorum conciliorum nova et amplissima collection, ed. J. D. Mansi, vol. 11: 801-830, Zatta: Florentiæ, Venetii.

Concilium Constantinopolitanum III. 1765b. Actio decima. In Sacrorum conciliorum nova et amplissima collection, ed. J. D. Mansi, vol. 11: 830-857. Zatta: Florentiæ, Venetii.

Concilium Constantinopolitanum IV. 1771a. Causae et praefatio. In Sacrorum conciliorum nova et amplissima collection, ed. J. D. Mansi, vol. 16: 1-13. Zatta: Florentiæ, Venetii.

Concilium Constantinopolitanum IV. 1771b. Subscriptiones. In Sacrorum conciliorum nova et amplissima collection, ed. J. D. Mansi, vol. 16: 189-196. Zatta: Florentiæ, Venetii.

Concilium Constantinopolitanum IV. 1771c. Actio decima-Canones. In Sacrorum conciliorum nova et amplissima collectio ed. J. D. Mansi, vol. 16: 398-410. Zatta: Florentiæ, Venetii.

Concilium Lateranense Romanum. 1763. Secretarius I-II. In Sacrorum conciliorum nova et amplissima collection, ed. J. D. Mansi, vol. 10: 863-1188. Zatta: Florentiæ, Venetii.

Concilium Nicaenum II. 1766. Actio tertia. In Sacrorum conciliorum nova et amplissima collection, ed. J. D. Mansi, vol. 12: 1113-1154. Zatta: Florentiæ, Venetii.

Concilium Nicaenum II. 1767a. Interpretatio subscriptionis Romanorum. In Sacrorum conciliorum nova et amplissima collection, ed. J. D. Mansi, vol. 13: 134-156. Zatta: Florentiæ, Venetii. 
Concilium Nicaenum II. 1767b. Actio quinta. In Sacrorum conciliorum nova et amplissima collection, ed. J. D. Mansi, vol. 13: 157-202. Zatta: Florentiæ, Venetii.

Concilium Nicaenum II. 1767c. Actio septima. In Sacrorum conciliorum nova et amplissima collection, ed. J. D. Mansi, vol. 13: 363-414. Zatta: Florentiæ, Venetii.

Constantinus Porphyrogenitus. 1864. Constantini Porphyrogeniti de administrando imperio. Patrologiae cursus completus. Series Graeca, ed. J.-P. Migne, vol. 113: 158-422. Parisiis: Garnier.

Concilium Trullanum. 1766. Subscriptiones. In Sacrorum conciliorum nova et amplissima collection, ed. J. D. Mansi, vol. 12: 987-1006. Zatta: Florentiæ, Venetii.

Cordier, H. 1917. Le Christianisme en Chine et en Asie Centrale sous les Mongols. T'oung Pao 18(1/2): 49-113.

Damascène, Jean. 1992. Écrits sur l'Islam. In Sources chrétiennes. ed. R. LeCoz, 383. Paris: Cerf.

Damascenus, Ioannes. 1864a. Libellus. In Patrologiae cursus completus. Series Graeca, ed. J.-P. Migne, vol. 114: 1421-1432. Parisiis: Garnier.

Damascenus, Ioannes. 1864b. Contra Jacobitas. In Patrologiae cursus completus. Series Graeca, ed. J.-P. Migne, vol. 114: 1135-1502. Parisiis: Garnier.

Damascenus, Ioannes. 1864c. Dialectica. In Patrologiae cursus completus. Series Graeca, ed. J.-P. Migne, vol. 114: 529-676. Parisiis: Garnier.

Damascenus, Ioannes. 1864d. De haeresibus. In Patrologiae cursus completus. Series Graeca, ed. J.-P. Migne, vol. 114: 677-780. Parisiis: Garnier.

Damascenus, Ioannes. 1864e. De fide orthodoxa. In Patrologiae cursus completus. Series Graeca, ed. J.-P. Migne, vol. 114: 789-1228. Parisiis: Garnier.

Damascenus, Ioannes. 1864f. Adversus constantinum caballinum. In Patrologiae cursus completus. Series Graeca, ed. J.-P. Migne, vol. 95: 336-337. Parisiis: Garnier.

Damascenus, Ioannes. 1864g. Expositio et declaratio fidei. In Patrologiae cursus completus. Series Graeca, ed. J.-P. Migne, vol. 95: 417-438. Parisiis: Garnier.

Damascenus, Ioannes. 1864h. Oratio pro sacris imanigibus. In Patrologiae cursus completus. Series Graeca, ed. J.-P. Migne, vol. 95: 1231-1420. Parisiis: Garnier.

de Damas, David. 2018. In L'Église melkite au ixe siècle à travers le conflit entre David de Damas et Siméon d'Antioche. Apports d'un dossier documentaire inédit, ed. M. Boudier. Annales Islamoligiques 52: 45-80.

de Nikioû, Jean. 1883. La Chronique de Jean de Nikioû.In Notices et Extraits des manuscrits de la Bibliothèque Nationale, ed. H. Zotenberg, vol. 24 (1): 125-605. Paris: Imprimerie National.

Demetriani, Vita. 1907. Saint Démétrianos, évêque de Chytri (île de Chypre). In Byzantinische Zeitschrift, ed. H. Grégoire, vol. 16: 217-237.

Dionysius of Tel-Maḥrē. 1993. The Seventh Century in the West-Syrian Chronicles. In Translated Texts for Historians, ed. A. Palmer. 15, 85-221. Liverpool: Liverpool University Press. 


\section{Bibliography}

Duchesne, L. 1925. Origines du culte chrétien: étude sur la liturgie latine avant Charlemagne. Paris: Boccard.

Einhard. 1880. The Life of Charlemagne translated. Ed. E. Turner. New York: Harper \& Brothers.

Einhard. 1911. Vita Karoli Magni. In Monumenta Germaniae historica in Scriptores rerum Germanicarum in usum scholarum, ed. O. Holder-Egger. Hanovre: Hahn.

Encyclical. 2020. Encyclical to the Eastern Patriarchs 866. University of Oregon. https://pages.uoregon.edu/sshoemak/324/texts/photius_encyclical. htm [accessed: 22.10.2020].

Epiphanius. 1916. Die Schriften des Epiphanius gegen die Bilderverehrung. ed. K. Holl. In Sitzungsberichte der Berliner Akademie der Wissenschaften, 828-868. Berlin: Berlin:Verlag der Königlichen Akademie der Wissenschaften.

Epistola ad Alexandrinorum Ecclesiam. 1767. Epistola Sanctae magnae et oecoumenicae Nicaenae Synodi ad Sanctissimam Alexandrinorum Ecclesiam. In Sacrorum conciliorum nova et amplissima collection, ed. J. D. Mansi, vol. 13: 809-820. Zatta: Florentiæ, Venetii.

Epistola Sacerdotum Orientis. 1766. Sacrorum conciliorum nova et amplissima collection, ed. J. D. Mansi, vol. 12: 1128-1136. Zatta: Florentiæ, Venetii.

Epistolae Merowingici et Karolini Aevi. 1892. Monumenta Germaniae Historica. Epistolae, ed. E. Dümmler, vol. 1: 3. Berlin: Weidmann.

Eusebius. 1999. The church history. In A New Translation with Commentary, ed. P. L. Maier. Grand Rapids: Kregel Publications.

Eutychius. 1906. Eutychii patriarchae Alexandrini annales. Scriptores Arabici textus, series tertia. In Corpus scriptorum christianorum orientalium, ed. L. Cheikho (text Arabic), vol. 6: 50. Berytii: E typographeo Catholico.

Eutychius. 1909. Eutychii patriarchae Alexandrini annals-Accedunt annales Yahia Ibn Said Antiochensis, Scriptores Arabici textus, series tertia. In Corpus scriptorum christianorum orientalium, ed. L. Cheikho and B. Carra de Vaux, vol. 7: 51. Berytii: E typographeo Catholico.

Ğāhiz. 1900. Le livre des avares par Abou Othman Amr Ibn Bahr al-Djahiz de Basra. Texte arabe, publié d'après le ms. Unique de Constantionople, ed. G. van Vloten. Leiden: Brill.

Ğāhiz. 1926. Talāt rasā'il li-'Abī-'Uțmān 'Amr Ibn-Baḥr al-Ǧāḥiz almutawaffā sanata 255 h sa 'ā fì našrihī Yūša' Finkal = Three Essays of Abu Othman Amr Ibn Bahr Al-Jahiz (d. 869), ed. J. Finkel. Cairo: Salafyah Press.

Gottheil, R. 1903. A Christian Bahira legend. New York: Reprinted from Zeitschrift für Assyrologie und verwandte Gebiete.

Gregorius II. 1766. Gregorii papae Romani de sacris imaginibus ad Leonem Isaurum Imperatorem, epistola secunda. In Sacrorum conciliorum nova et amplissima collectio, ed. J. D. Mansi, vol. 12: 975-992. Zatta: Florentiæ, Venetii.

Griffith, S. H. 1986. Greek into Arabic: life and letters in the monasteries of Palestine in the ninth century; the example of the Summa Theologiae Arabica. Byzantion 56: 117-138. 
Griffith, S. H. 2008. John of Damascus and the Church in Syria in the Umayyad Era: The Intellectual and Cultural Milieu of Orthodox Christians in the World of Islam. Hugoye 11(2): 207-237.

Griffith, S. H. 1979. Some unpublished Arabic sayings attributed to Theodore Abu Qurrah. Le muséon 92: 29-35.

Griffith S. H. 1985a. The Gospel in Arabic: An Inquiry into its Appearance in the First Abbasid Century. Oriens christianus 69: 126-167.

Griffith, S. H. 1985b. The Arabic Account of 'Abd al-Masih an-Nagrani al-Ghassani. Le muséon 98: 331-374.

Grunebaum, G. E. von. 1962. L' Islam médiéval: histoire et civilisation. Paris: Payot.

Hagiography. 2014. Hagiography, ed. J. C. Lamoreaux. In The Orthodox Church in the Arab World, 700-1700: An Anthology of Sources, ed. S. Noble and A. Treiger, 112-135. Ithaca: Cornell University Press.

Hasson, I. 1996. The Muslim View of Jerusalem: The Quran and Hadith. In The History of Jerusalem: The Early Muslim Period, eds. J. Prawer and H. Ben Shammai. 349-385. New York and Jerusalem: New York University Press and Yad Izhak Ben-Zvi.

Hayek, M. 1964. Liturgie maronite. Histoire et textes eucharistiques. Tours: Mame.

Hefele, K. Joseph von. 1911. Histoire des conciles d'après les documents originaux. Vol. 4. Paris: Letouzey \& Ané.

Hickley, D. 1980. The First Christians in Chinaan Outline History and Some Considerations Concerning the Nestorians in China During the Tang Dynasty. London: China Study Project, in association with Missio Aachen.

Hierosolymitanum, Ioannes. 1864. Liber adversus Iconoclastas opusculum adversus iconoclastos. In Patrologiae cursus completus. Series Graeca, ed. J.-P. Migne, vol. 96: 1347-1362. Parisiis: Garnier.

Histoire d'Héraclius. 1904. Histoire d'Héraclius: par l'évêque Sebèos. Ed. F. Mecler. Paris: Imprimerie Nationale.

Ibn Sallām, Muḥammad Ḥāmid al-Faq̄ī Abū-'Ubaid al-Qāsim 1935. Kitab al-Amwal. al- Qāhira: al- Maṭba'a al- 'āmira.

Ignatius. 2021. Epistle of Ignatius to the Romans, ed. B. C. Smith. http:// www.textexcavation.com/greekignatiusromans.html [accessed 12.12.2020].

Ignatius. 2019. Ignatius of Antioch. A mysterious martyr letters. Letters of Ignatius. In M. Vinzent. Early Christianity From Reception to Retrospection, 266-282. Cambridge: Cambridge University Press.

Ignatius Patriarcha Constantinopolitanus. 1771. Theodosii Patriarchae Hierosolymorum ad Ignatiam Patriarcham Constant. In Sacrorum conciliorum nova et amplissima collectio, ed. J. D. Mansi, vol. 16: 25-27. Zatta: Florentiæ, Venetii.

Ioannis. 2000. Ioannis Malalae Chronographia. Ed. J. Thurn. Corpus Fontium Historiae Byzantinae 35. Berlin, New York: Walter de Gruyter.

Ioannis Malalae Chronographia. 2000. Ed. Johannes Thurn. Corpus Fontium Historiae Byzantinae 35. Berlin, New York: Walter de Gruyter. 'Izz al-Dīn (al-), Ațīr ibn. 2001. Al-Kāmil fi 'at-Tārīhh, ed. 'Umar 'Abd as-Salām Tadmurī, vol. 1-11. Bayrūt: Dār al-Kutub. 


\section{Bibliography}

Jean de Nikioû. 1883. La Chronique de Jean de Nikioû. In No-tices et Extraits des manuscrits de la Bibliothèque Nationale, ed. H. Zotenberg, 24:1: 125-605. Paris: Imprimerie National.

Kennedy, H. 1990. The Barmakid Revolution in Islamic Government Pembroke Persian Papers: History and Literature in Iran. Ed. Ch. Melville. 89-98. Cambridge: E \& E Plumbridge Ltd.

Kontouma, V. 2015. John of Damascus: New Studies on his Life and Works. London: Routledge.

Koran. 1986, ed. J. Bielawski. Warszawa: PIW.

Landau-Tasseron, E. 2000. New data on an old manuscript: An Andalusian version of the work entitled Futūh al-Shām. Al-Qanțara 21: 2. https://alqantara.revistas.csic.es/index.php/al-qantara/article/view/431/422 [accessed 12.10.2020].

Latourette, K.S. 1929. A history of Christian missions in China. New York: Macmillan.

Le Coz, R. 1992. Écrits sur l'Islam/Jean Damascène. Présentation, commentaires et traduction. Paris: Éd. du Cerf.

Leo VI Sapiens. 1863a. Epistola ad Omarum Saracenum de fidei Christianae veritate \& Saracenorum erroribus, In Patrologiae cursus completus. Series Graeca, ed. J.-P. Migne, vol. 107: 315-324. Parisiis: Garnier.

Leo VI Sapiens. 1863b. Tactica. In Patrologiae cursus completus. Series Graeca, ed. J.-P. Migne, vol. 107: 669-1116. Parisiis: Garnier.

Léon VI. 1944. Les novelles de Léon VI le Sage. In Texte et traduction, ed. P. Noailles and A. Dain. Paris: Société d'édition "Les belles lettres".

le Syrien, Michael. 1899. Chronique de Michael le Syrien, Patriarche Jacobite d'Antioche, 1166-1199 A.D., ed. J.-B. Chabot, vol. 1. Paris: E. Leroux.

le Syrien, Michael. 1901. Chronique de Michael le Syrien, Patriarche Jacobite d'Antioche, 1166-1199 A.D., ed. J.-B. Chabot, vol. 2. Paris: E. Leroux.

le Syrien, Michael. 1905. Chronique de Michael le Syrien, Patriarche Jacobite d'Antioche, 1166-1199 A.D., ed. J.-B. Chabot, vol. 3. Paris: E. Leroux.

le Syrien, Michael. 1910. Chronique de Michael le Syrien, Patriarche Jacobite d'Antioche, 1166-1199 A.D., ed. J.-B. Chabot, vol. 4 (Syriac). Paris: E. Leroux.

Les Regestes. 1936. Les Regestes des actes du patriarcat de Constantinople, ed. V. Grumel. Paris: Imprimerie nouvelle.

Les Regestes . 1989. Les regestes des actes du Patriarcat de Constantinople. Vol. 1: Les Actes des patriarches. Fasc. II et III, Les Regestes de 715 à 1206, ed. V. Grumel and J. Darrouzès. Le Patriarcat byzantin 1. Paris: Institut français d'études byzantines.

Libellus Monachorum. 1763. Libellus Monachorum-Secretarius II, Epistolae et decreta Martini papae I. In Sacrorum conciliorum nova et amplissima collection, ed. J. D. Mansi, vol. 10: 903-910. Zatta: Florentiæ, Venetii.

Liber Pontificalis. 1886. Le Liber Pontificalis. Texte, introduction et commentaire, ed. L. Duchesne, vol. 1. Paris: Ernest Thorin.

Liber Pontificalis. 1892. Le Liber Pontificalis. Texte, introduction et commentaire, ed. L. Duchesne, vol. 2. Paris: Ernest Thorin.

Life of Maximus 1973. An early Syriac life of Maximus the confessor, ed. S. Brock. Analecta Bollandiana 91: 299-346. 
Lilie, R.-J. 1976. Die byzantinische Reaktion auf die Ausbreitung der Araber: Studien zur Strukturwandlung des byzantinischen Staates im 7. und 8. Jhd. München: Inst. f. Byzantinistik u. Neugriech. Philologie d. Univ.

Lūqā, Qusțā ibn. 1981. Une correspondance islamo-chrétienne entre ibn al-Munaggim, Hunaym ibn Ishaq et Qusta ibn Luqa, ed. K. Samir and P. Nwyia. Patrologia Orientalis 40: 4. Turnhout: Brepols.

Maçoudi. 1896. Le livre de l'avertissement et de la révision [par] Maçoudi, ed. B. Carra de Vaux. Paris: Imprimerie nationale. https://archive.org/stream/ lelivredelaverti00masuuoft\#page/n11/mode/2up [accessed 12.034.2020].

Madey, J. 1998. Melchicki Kościół. In Słownik chrześcijaństwa wschodniego. Ed. J. Assfalg, P. Krüger, 206-208. Katowice: Książnica.

Martin, M. 1985. Une lecture de l'Histoire des Patriarches d'Alexandrie. Proche-Orient Chrétien 35: 15-36.

Martinus I. 1763a. Ad Theodorum (no XIV), Epistolae et decreta Martini papae I. In Sacrorum conciliorum nova et amplissima collectio, ed. J. D. Mansi, vol. 10: 849-850. Zatta: Florentiæ, Venetii.

Martinus I. 1763b. Ad Ecclesiam Hierosolymitanam et Antiochenam, Epistolae et decreta Martini papae I. In Sacrorum conciliorum nova et amplissima collectio, ed. J. D. Mansi, vol. 10: 827-832. Zatta: Florentiæ, Venetii.

Massignon, L. 1963. Textes recueillis, classes et presentes avec une bibliographie par Y. Moubarac. Vol. 1: Islam, culture et société islamiques. Beirut: Dar al-Maaref.

Mas'ūdī Meynard and Courteille. 1861-1877. Les prairies d'or/Maçoudi; texte et traduction. Ed. C. B. de Meynard and P. de Courteille. vol. 1-9. Paris: Imprimerie Impériale.

Mas'ūdī Pellat. 1979. Les Prairies d'Or. Ed. Ch. Pellat. Beirut: Publications de l'Université Libanaise.

Māwardī, 'Alī Ibn-Muḥammad al-. 1909. Kitāb al-Aḥkām as-sulțānīya. Miṣr: Maṭba at as-Sa'āda.

Moule, A. C. 1940. Nestorians in China: Some Corrections \& Additions. London: The China Society.

Muqqaffa'. 1904. The History of the Patriarchs of the Coptic Church of Alexandria, ed. B. Evetts, vol. 1. Patrologia Orientalis 1: 2. Paris: Firmin-Didot.

Muqqaffa'. 1907. The History of the Patriarchs of the Coptic Church of Alexandria, ed. B. Evetts, vol. 2. Patrologia Orientalis 1: 4. Paris: Firmin-Didot.

Muqqaffa'. 1910a. The History of the Patriarchs of the Coptic Church of Alexandria, ed. B. Evetts, vol. 3. Patrologia Orientalis 5: 1. Paris: FirminDidot.

Muqqaffa'. 1910b. The History of the Patriarchs of the Coptic Church of Alexandria, ed. B. Evetts, vol. 4. Patrologia Orientalis 10: 1. Paris: FirminDidot.

Muqqaffa'. 1910c. The History of the Patriarchs of the Coptic Church of Alexandria, ed. B. Evetts, vol. 5. Patrologia Orientalis 10: 5. Paris: FirminDidot.

Nicephorus. 1863. Sancti Nicephori breviarium historicum de rebus gestis post Mauricii imperium. In Patrologiae cursus completus. Series Graeca, ed. J.-P. Migne, vol. 100: 683-994. Parisiis: Garnier. 
Nicholas I Patriarch of Constantinople. 1973. Letters, ed. R. J. H. Jenkins and L. G. Westerink. Washington: Dumbarton Oaks Pub Service.

Olewiński, D. J. 2004. Um die Ehre des Bildes: theologische Motive der Bilderverteidigung bei Johannes von Damaskus. St. Ottilien: EOS-Verlag.

Oriens Christianus. 1740. Oriens Christianus in quattuor Patriarchatus digestus; quo Exibentur Ecclesiae, Patriarchae, caeterique Praesules totius Orientis, ed. M. le Quien. Parisiis: Typographia Regia.

Procopius. 2008. The Persian wars. In The Project Gutenberg eBook, ed. H. B. Dewing. https://www.gutenberg.org/files/16764/16764-h/16764-h. htm [accessed 26.11.2020].

Procopius. 1962-1964. Procopii Caesariensis opera omnia. Ed. J. Haury; revised by G. Wirth. vol. 1-4. Leipzig: Teubner.

Prokopios. 2010. The Secret History. Ed. A. Kaldellis. Indianapolis: Hackett Publishing.

Pseudosynodus Photiana. 1772. Epistola: A Deo designatis Imperatoribus, Basilio Leoni et Alexandro, Michael archiepiscopus Alexandriae. In Sacrorum conciliorum nova et amplissima collectio, ed. J. D. Mansi, vol. 17: 259-263. Zatta: Florentiæ, Venetii.

Qurra, Theodore Abu. 2014. The Orthodox Church in the Arab World, 700-1700: An Anthology of Sources, ed. J. C. Lamoreaux, S. Noble and A. Treiger, 60-89. Ithaca: Cornell University Press.

Richter, G. 1964. Dialektik des Johannes von Damaskos: Eine Untersuchung d. Textes nach seinen Quellen u. seiner Bedeutung. Ettal: Buch-Kunstverlag.

Richter, G. M. A. 1946. Greeks in Persia. American Journal of Archaeology 50(1): 15-30.

Šaddād, Ibn. 1963. A 'āa al-ḩatīra, ed. S. Dahhan. Dimašq: Al-Ma'had alfaransīya li-d-dirāsāt al- 'arabīya.

Šāfi ī. 1961. Šăf'ī al-Imām Abū Abd Allah Muḥammad ibn Idrīs (al-), Kitāb al-umm, ed. M. Z. Nağğar, vol. 1-8. Al-Qāhira: Maktabat al-kullīyāt al-azharīya.

Sa'id, Yahya ibn. 1924. Histoire de Yahya-Ibn-Sa'id d'Antioche, continuateur de Sa'id-Ibn-Bitriq. In Patrologia orientalis, ed. I. Kratchkovsky and A. Vasiliev, vol. 18: 705-833. Paris: Firmin-Didot.

Schatz, K. 2004. Prymat papieski od początków do współczesności. Kraków: WAM.

Schönborn, Ch. von. 1972. Sophrone de Jérusalem: vie monastique et confession dogmatique. Paris: Beauchesne.

Seleznyov, N. 2010. Nestorius of Constantinople: Condemnation, Suppression, Veneration: With special reference to the role of his name in East-Syriac Christianity. Journal of Eastern Christian Studies 62(3-4): 165-190.

Sims-Williams, N. 1992. Christianity, iii. In Central Asia and Chinese Turkestan. In EncyclopaediaIranica. Vol. 5. 530-534. London: Routledge \& Kegan Paul.

Sophronius. 1863. Sancti Sophroni Hierosolymitani Orationis VIII. In Patrologiae cursus completus. Series Graeca, ed. J.-P. Migne, vol. 87: 3: 3201-3364. Parisiis: Garnier. 
Sophronius. 2009. Sophronius of Jerusalem and Seventh-Century Heresy: The Synodical Letter and Other Documents. In Oxford Early Christian Texts, ed. P. Allen. Oxford: Oxford University Press.

Stead, G. C. 1964. The platonism of Arius. The Journal of Theological Studies New Series 15(1): 16-31.

Subscriptiones. 1765. Exemplum literarum missarum ad Agathonem Papam, Subscriptiones, In Sacrorum conciliorum nova et amplissima collectio, ed. J. D. Mansi, vol. 11: 687-694. Zatta: Florentiæ, Venetii.

Sulāymān, Mārī ibn. 1896. Maris textus arabicus. In Aḥbār batarikāt kursī al-Mašriq, min kitāb al-Miğdal, Maris, Amri et Slibae De patriarchis Nestorianorum commentaria: ex codicibus Vaticanis, ed. E. Gismondi, vol. 1. Romae: de Luigi.

Sulāymān, Mārī ibn. 1899. Maris textus arabicus. Aḩbār batarikāt kursī alMašriq, min kitāb al-Miğdal, Maris, Amri et Slibae De patriarchis Nestorianorum commentaria: ex codicibus Vaticanis, ed. E. Gismondi, vol. 2. Romae: de Luigi.

Șūlī. 1946. Histoire de la dynastie abbaside de 322-333/934-944 par Mohammed ben Yāhya al-Ṣūî. In Publications de l'institut orientales de la Faculté des letters d'Alger 10, ed. M. Canard, vol. 1. Alger: Jules Carbonel.

Șūlī. 1950. Histoire de la dynastie abbaside de 322-333/934-944 par Mohammed ben Yāhya al-Șūî̀. In Publications de l'institut orientales de la Faculté des letters d'Alger 12, ed. M. Canard, vol. 2. Alger: Jules Carbonel.

Synodus Constantinopolitana. 1763. Historia Quintae Sinodi Constantinopolitanae, Collectio Septima. In Sacrorum conciliorum nova et amplissima collection, ed. J. D. Mansi, vol. 9: 345-367. Zatta: Florentiæ, Venetii.

Synodus, Niceana. 1767. Pro synodo Niceana II 759-810. In Sacrorum conciliorum nova et amplissima collectio, ed. J. D. Mansi, vol. 13: 759-810. Zatta: Florentiæ, Venetii.

Ta âlibī. 1885. 'Abd-al-Malik Ibn-Muhammad at-Ta ālibī, Yatīmat ad-dahr fī maḥāsin ahl al-'aṣr, vol. 1. Dimašq: al-Matbaa al-Hifniya.

Tabarī. 1987. The History of al-Tabari. Vol. 18: Between Civil Wars: The Caliphate of Mu'awiyah A.D. 661-680/A.H. 40-60, ed. M. G. Morony. New York: The State University of New York Press.

Tabarī. 1990. The History of al-Tabari. Vol. 13: The Conquest of Iraq, Southwestern Persia, and Egypt: The Middle Years of 'Umar's Caliphate A.D. 636-642/A.H. 15-21, ed. G. H. A. Juynboll. New York: The State University of New York Press.

Tabarī. 1991a. The History of al-Tabari. Vol. 12: The Battle of alQadisiyyah and the Conquest of Syria and Palestine A.D. 635-637/A.H. 14-15, ed. Y. Friedmann. New York: The State University of New York Press.

Ṭabarī. 1991b. [Extraits de Tārīh al-rusul wa-l-mulūk]: al-Mutawakkil et les chrétiens. In Al-Dimma: l'islam et les minorités religieuses. Études arabes dossiers. Pontificio Istituto di Studi Arabi e d'Islamistica, ed. M. Borrmans, 96-103. Roma: Pontificio Istituto di Studi Arabi e d'Islamistica. 
Tarras, P. 2017. The Spirit Before the Letter: Theodore Abū Qurra's Use of Biblical Quotations in the Context of Early Christian Arabic Apologetics. In The Bible in Arabic among Jews, Christians and Muslims. Biblia Arabica, ed. M. L. Hjälm. 79-103. Leiden: Brill.

The Council of Constantinople, 1990. Session III - 680-681 A. D. In Decrees of the ecumenical councils, 1: Nicea I to Lateran V, ed. N.P. Tanner. London: Sheed \& Ward https://www.ewtn.com/catholicism/library/councilof-constantinople---exposition-of-faith-1457 [accessed 22.10.2020].

The First Council of Nice. 2020. Excursus on the Rise of the Patriarchate of Jerusalem. Christian Classes Ethereal Library. https://www.ccel.org/ccel/ schaff/npnf214.vii.vi.x.html [10.12.2020].

Théodore, Abuqurra. 1986. Maimar fĩ ikrām al-aiqūnāt li-Tāouudūrus AbīQurra Haqqaqahū Ig̀nātiyūs Dīk. Théodore Abuqurra, traité du culte des icons: introduction et texte critique, ed. I. Dick. Patrimoine arabe chrétien 10. Roma: Pontificio Istituto Orientale.

Theodosius patriarcha Antiochiae. 1772. Epistola: Sanctissimo patriarchae Constantinopoleos Theodosius peccator, patriarcha Antiochiae. In Sacrorum conciliorum nova et amplissima collectio, ed. J. D. Mansi, vol. 17: 443-450. Zatta: Florentiæ, Venetii.

Theodotius Patriarcha Hierosolymorum. 1772. Epistola: A Deo electo, sancto et percelebri comministro nostro domino Photio, patriarchae Constantinopoleos, Theodotius minimus patriarcha Hierosolymorum. In Sacrorum conciliorum nova et amplissima collectio ed. J. D. Mansi, vol. 17: 441-444. Zatta: Florentiæ, Venetii.

Theophanes Continuatus. 1863. In Patrologiae cursus completus. Series Graeca, ed. J.-P. Migne, vol. 109: 15-499. Parisiis: Garnier.

Theophanes. 1883. Theophanis Chronographia, ed. C. de Boor, vol. 1 (text Greek). Lipsiae: B. G. Teubnneri.

Theophanes. 1885. Theophanis Chronographia, ed. C. de Boor, vol. 2. Lipsiae: B. G. Teubnneri.

Tomus ad Flavianum. 1846. Patrologiae cursus completus. Series Latina, ed. J.-P. Migne, vol. 54: 775-779. Parisiis: Garnier.

Warrāq. 1992. Anti-Christian Polemic in Early Islam: Abū 'Īsā al-Warrāq's, against the Trinity, ed. D. Thomas. Cambridge: Cambridge University Press.

von Damaskos, Johannes. 1969-2013. Die Schriften des Johannes von Damaskos, ed. B. Kotter and R. Volk, vols. 1-7. Berlin-New York: De Gruyter.

von Skythopolis, Kyrillos. 1939. Leben des Sabas. In Kyrillos von Skythopolis, ed. E. Schwartz. Texte und Untersuchungen 49 (2): 85-200. Leipzig: Hinrichs.

Ya 'qūb, Abū Yūsuf. 1932. Abū Yūsuf Ya qūb ibn Ibrāhīm al- Kūfī, Kitāb arRadd 'alā Siyar al-Auzā' ì. Al-Qāhira: Dār al-Kutub al-Mișrīya.

Yūḥannā al-Anțākī, Ibrāhīm ibn. 1952. Vie du patriarche melkite d'Antioche Christophore (967) par le pnotospathare Ibrahim b. Yuhanna. Document inedite de X s, ed. H. Zayyāt. Proche Orient Chrétien 2: 20-29. 
Zayat, H. 1949. Signes distinctifs des chrétiens et des juifs en Islam. La croix, la ceinture, le turban et la rondelle. Revue Al-Maschreq 63: 161-251.

Zimmermann, M. 1989. En els orígens de Catalunya: emancipació política i afirmació cultural. Barcelona: Edicions, 62.

\section{Case studies}

Abel, A. 1949. La convention de Nadjrân et le développement du «droit des gens» dans l'islam Classique. Bruxelles: S. C. Imprimerie Groeninghe.

Abel, A. 1963. Le chapitre CI du Livre des heresies de Jean Damascène: son authenticité. Studia Islamica 19: 5-25.

Abel, A. 1970. La djizya: tribut ou rançon? Studia Islamica 32: 5-19.

Abramowski, L. 1940. Dionysius von Tellmahre, jakobitischer Patriarch von, 818-843. Leipzig: Brockhaus.

Abramowski, L. 1955-1956. Der Streit um Diodor und Theodor von Mopsuestia zwischen den beiden ephesinischen Konzilien. Zeitschrift für Kirchengeschichte 67: 252-287.

Abu Assab, N. 2014. The Umayyads' Attitude towards the Christian Sacred Sites in Islamic Jerusalem. Journal of Islamic Jerusalem Studies 14: 24-96.

Agachi, A. 2016. A critical presentation of the work of Theodore Abu Qurrah in defense of icons. Heythrop Journal 57(2): 259-268.

Ahrweiler, H. 1962. L'Asie Mineure et les invasions arabes $\left(\mathrm{VII}^{\mathrm{e}}-\mathrm{IX}^{\mathrm{e}}\right.$ siècles). Revue historique 227: 1-32.

Alexander, P. J. 1958. The Patriarch Nicephorus of Constantinople. Ecclesiastical Policy and Image Worship in the Byzantine Empire. Oxford: Clarendon Press.

Allard, M. 1962. Les Chrétiens à Bagdad. Arabica 9: 375-388.

Altmann, H. 2003. Die Reise des Isaak und die politische situation um 800. In Ex Oriente: Isaak und der weisse Elefant: Die Reise des Isaak, Bagdad, Zabern, Aachen: Aachen, ed. W. Dreßen and G. Minkenberg, vol. 1: 28-35. Aachen: Domkapitel Aachen.

Amann, É. 1924. Église de Jérusalem. In Dictionnaire de théologie catholique, ed. A. Vacant, vol. 8: 1: 997-1010. Paris: Letouzey et Ané.

Amélineau, E. 1899. Fragments coptes pour servir à l'histoire de la Conquête de l'Égypte par les Arabes. Paris: Imprimerie nationale.

Amelotti, M. 2001. Giustiniano tra teologia e dritto. Studia et documenta historiae et iuris 67: 469-491.

Anastos, M. V. 1968. Leo III's Edict against the Images in the Year 726-727 and Italo-Byzantine Relations between 726 and 730. Byzantinische Forschungen 3: 5-41.

Anawati, G. C. 1990. The Christian communities in Egypt in the Middle Ages. In Conversion and Continuity. Indigenous Christian Communities in Islamic Lands. Eighth to Eighteenth Centuries, ed. M. Gervers, R. I. Birkhazi, 237-252. Toronto: Pontifical Institute of Mediaeval Studies.

Anjum, O. 2012. Politics, Law, and Community in Islamic Thought: The Taymiyyan Moment. Cambridge: Cambridge University Press.

Arnold, T. W. 2000. The Caliphate. Oxford: Oxford University Press. 
Asmussen, J. P. 1962. Das Christentum in Iran und sein Verhältnis zur Zoroastrismus. Studia Theologica-Nordic Journal of Theology 16: 1: $1-24$.

Asmussen, J. P. 1968. Christians in Iran. In The Cambridge History of Iran: The Seleucid, Parthian and Sasanid Periods, ed. E. Yarshater, vol. 3: 2: 924-948. Cambridge: Cambridge University Press.

Atiya, A. S. 1978. Historia Kościołów wschodnich. Warszawa: PAX.

Attila, J. 2001. Ecclesia Alexandrina: évolution sociale et institutionnelle du christianisme alexandrin ( $\mathrm{II}^{\mathrm{e}}-\mathrm{III}^{\mathrm{e}}$ siècles). Berne: Peter Lang.

Auzépy, M.-F. 1999. L'hagiographie et l'iconoclasme byzantin. Le cas de la vie d'Etienne le Jeune. Aldershot: Ashgate.

Avni, G. 2010. The Persian conquest of Jerusalem (614 CE). An archeological assessment. The Bible and Interpretation. October. http://www. bibleinterp.com/articles/pers357904.shtml [accessed 22.11.2020].

Avni, G. 2011. From Hagia Polis to Al-Quds: The Byzantine-Islamic transition in Jerusalem. In Unearthing Jerusalem, 150 Years of Archaeological Research in the Holy City, ed. K. Galor and G. Avni, 387-398. Winona Lake: Eisenbrauns.

Awaisi, A. F. 2000. Umar's assurance of safety to the people of Aelia (Jerusalem): a critical analytical study of the historical sources. Journal of Islamic Jerusalem Studies 3: 2: 47-49.

Bacht, H. 1956. Antonius magnus eremita: 356-1956: studia ad antiquum monachismum spectantia. Roma: Orbis Catholicus.

Bagatti, B. 1968. L’Église de la gentilité en Palestine. Jérusalem: Impr. des PP. Franciscains.

Bailey, N. A. 2004. The battle of Yarmouk. Journal of U.S. Intelligence Studies 14: 1: 17-22.

Baladi, N. 1951. Les saintes images, leur nature et pouvoir d'après Saint Jean Damascène. Proche Orient Chrétien 1: 13-25.

Bar, D. 2005. Rural Monasticism as a Key Element in the Christianization of Byzantine Palestine. The Harvard Theological Review 98: 1: 49-65.

Barbero, A. 2004. Charlemagne: Father of a Continent. Berkeley: University of California Press.

Bardy, G. 1937. Aux origins de l'école d'Alexandrie. Recherches de science religieuse 27: 65-90.

Bardy, G. 1942. Pour l'école d'Alexandrie. Vivre et penser 50: 80-109.

Baumkamp, E. 2014. Kommunikation in der Kirche des 3. Jahrhunderts. Bischöfe und Gemeinden zwischen Konflikt und Konsens im Imperium Romanum. Studien und Texte zu Antike und Christentum, 92. Tübingen: Mohr Siebeck.

Baumstark, A. 1953. Liturgie comparée, principes et méthodes pour l'étude historique des liturgies chrétiennes. Paris: Ed. de Chevetogne.

Baur, C. 1929-1930. Der heilige Johannes un seine Zeit, vol. 1-2. München: M. Hueber.

Baynes, H. N. 1913. The military operations of Emperator Heraclius. The United Service Magazine 47: 665-667. 
Beaumont, M. 2005. Christology in Dialogue with Muslims: A Critical Analysis of Christian Presentations of Christ for Muslims from the Ninth and Twentieth Centuries. Oxford: Regnum.

Beck, H. G. 1959. Kirche und theologische Literatur im byzantinischen Reich. München: C.H. Beck'sche Verlagsbuchhandlung.

Becker, C. H. 1924. Islamstudien. Vom Werden und Wesen der islamischen Welt, vol. 1-2. Leipzig: Quelle und Meyer.

Ben-Ami, D., Tchekhanovets, Y., and Bijovsky, G. 2010. New archaeological and numismatic evidence for the Persian Destruction of Jerusalem in 614 CE. Israel Exploration Journal 60: 2: 204-221.

Bieberstein, K. 1993. Der Gesandtenaustausch zwischen Karl dem Großen und Hārūn ar-Rašīd und seine Bedeutung für die Kirchen Jerusalems. Zeitschrift des Deutschen Palästina-Vereins 109: 2: 152-173.

Biriukov, D. 2016. The Topic of the Universal in the Thought of the Cappadocian Fathers and in the Arian Debate of the 4th Century AD: Philosophical and Theological Perspectives, [Ph.D. thesis]. Padova Digital University Archive. http://paduaresearch.cab.unipd.it/9230/ [accessed 22.10.2020].

Björkman, W. 1965. Karl und der Islam. In Karl der Große: Lebenswerk und Nachleben, vol. 1: Persönlichkeit und Geschichte, ed. H. Beumann, 672-682. Düsseldorf: Schwann.

Blake, R. 1965. La littérature grecque en Palestine au VIIIe siècle. Le Muséon 78: 367-380.

Blau, J. 1961. The Importance of Middle Arabic Dialects for the History of Arabic. Jerusalem: Magnes.

Bomes, K. 1976. Weizen Gottes. Untersuchungen zur Theologie des Martyriums bei Ignatius. Köln-Bonn: Heinstein.

Boojama, J. 1981. Constantine and Justynian Orthodox Synthesis. Crestwood: Vladimir's Seminary Press.

Booth, P. H. 2016. The last years of Cyrus, patriarch of Alexandria (†642). In Mélanges Jean Gascou: textes et études papyrologiques, ed. J.-L. Fourner and A. Papaconstantinou. Travaux et mémoires 20: 1: 509-558. Paris: Association des Amis du Centre d'Histoire et Civilisation de Byzance.

Bordi, G. 2008. Gli affreschi di San Saba sul piccolo Aventino: dove e come erano. Milano: Jaka Book.

Bordi, G. 2009. Un pictor, un magister e un'iscrizione 'enigmatica' nella chiesa inferiore di San Saba a Roma nella prima metà del X secolo. Opera-Nomina - Historiae. Giornale di cultura artistica 1: 51-76.

Borgolte, M. 1976. Der Gesandtenaustausch der Karolinger mit den Abbasiden und mit den Patriarchen von Jerusalem. München: ArbeoGesellschaft.

Borgolte, M. 2013. Karl der Große. Sein Platz in der Globalgeschichte. Saeculum. Jahrbuch für Universalgeschichte 63: 2: 167-188.

Borrmans, M. 1981. Jérusalem dans la tradition religieuse musulmane. Islamochristiana 7: 1-18.

Bosio, G., dal Covolo, E., and Maritano, M. 1990. Introduzione ai padri della Chiesa. Secoli I-II. Torino: SEI. 


\section{Bibliography}

Boudier, M. 2018. L'Église melkite au ixe siècle à travers le conflit entre David de Damas et Siméon d'Antioche. Annales Islamoligiques 52: 45-80.

Boulliet, W. 1979. Conversion to Islam in the Medieval Period. Harvard: Harvard University Press.

Bousquet, G. H. 1956. Observations sur la nature et les causes de la conquête arabe. Studia Islamica 6: 37-52.

Bradshaw, P. F. 2003. New SCM Dictionary of Liturgy and Worship. London: Westminster John Knox Press.

Bréhier, L. 1904. La querelle des images (VIIIe-IXe siècles). Paris: Bloud.

Bréhier, L. 1919. Les origines des rapports entre les Francs et la Syrie: Le protectorat de Charlemagne, in Chambre de commerce de Marseille. In Congrès français de la Syrie (3, 4 et 5 janvier 1919). Séances et travaux: Section d'archéologie, histoire, géographie et ethnographie, 15-39. Marseille: Secrétariat chambre de commerce, Paris: Librairie ancienne H. Champion.

Bréhier, L. 1928. Les Croisades. L'Église et l'Orient au Moyen Âge. Paris: Librairie Victor Lecoffre.

Bréhier, L. 1948. La politique religieuse de Justinien. In Histoire de l'Église depuis les origins jusqu'à nos jour ed. A. Fliche and V. Martin, vol. 4: 437-482. Paris: éditions de l'Orante.

Breydy, M. 1983. Études sur Sa ${ }^{\top} \overline{1} d$ ibm Batrīq et ses sources. Corpus Scriptorum Christianorum Orientalium, 450. Louvain: Peeters.

Brezzi, P. 1950. La gnosi cristiana di Alessandria e le antiche scuole cristiane. Roma: Edizioni Italiane.

Brock, S. P. 1972. A short Melkite baptismal service in Syriac. Parole de l'Orient 3: 1: 119-130.

Brock, S. P. 1996. The 'Nestorian' Church: a lamentable misnomer. Bulletin of the John Rylands Library 78: 3: 23-35.

Brockelmann, C. 1943. Geschichte der arabischen Litteratur, vol. 1-3. Leiden: Brill.

Bronwen, N. 2010. Review of Sophronius of Jerusalem and Seventh-Century Heresy. The synodical letter and other documents. The Catholic Historical Review 96: 2: 321-322.

Brooks, E. W. 1898. The Arab in Asia Minor (641-750) from Arabic sources. Journal of Hellenic Studies 18: 182-208.

Bulliet, R. W. 1979. Conversion to Islam in the Medieval Period. Cambridge: Harvard University Press.

Bundy, D. D. 1978. Jacob Baradaeus. The State of Research. A Review of Sources and a New Approach. Le Muséon 91: 45-86.

Burmester, O. H. E. 1967. The Egyptian or Coptic Church. In A Detailed Description of Her Liturgical Services and the Rites and Ceremonies Observed in the Administration of Her Sacraments. Cairo: Société d'archéologie copte.

Busse, H. 1969. Chalif und Großkönig Chalif und Großkönig. Die Buyiden im Iraq, 945-1055. Beiruth: Steiner.

Butler, A. 1978. The Arab Conquest of Egypt and the Last Thirty Years of the Roman Dominion, ed. P. M. Fraser. Oxford: Clarendon Press.

Caetani, L. 1912. Chronographia islamica: ossia Riassunto cronologico della storia di tutti i popoli musulmani dall'anno 1 all'anno 922 della 
higrah (622-1517 dell'èra volgare) corredato della bibliografia di tutte le principali fonti stampate e manoscritte, vol. 1. Paris: Geuthner.

Cahen, C. 1953. L'évolution de l'iqtâ' du IXe au XIIIe siècle: Contribution à une histoire comparée des sociétés médiévales. Annales: Economies, Sociétés, Civilisations 8: 1: 25-52.

Cahen, C. 1954. Fiscalité, propriété, antagonisme sociaux en HauteMésopotamie au temps des premiers Abbassides, d'après Denys de TellMahré. Arabica 1: 136-153.

Cahen, C. 1970. Note sur les origines de la communauté syrienne des Nușayrīs. Revue des études islamiques 38: 243-249.

Camelot, T. 1951. De Nestorius à Eutyches: l'opposition de deux christologies. In Das Konzil von Chalkedon, Geschichte und Gegenwart, vol. 1: Der Glaube von Chalkedon, ed. A. Grillmeier, 213-242. Würzburg: Echter Verlag.

Camelot, T. 1962. Ephèse et Chalcédoine. Paris: éd. de l'Orante.

Cameron, A. and Conrad, L. I. (ed.). 1992. The Byzantine and Early Islamic Near East, vol. 1: Problems in the Literary Source Material. Princeton: The Darwin Press.

Canard, M. 1962. Bagdad au IVe siècle de l'Hégire $\left(\mathrm{X}^{\mathrm{e}}\right.$ siècle de l'ère chrétienne). Arabica 9: 267-287.

Canard, M. 1965. Djarādjima. In Encyclopédie de l'lslam, nouvelle. Établie avec le concours des principaux orientalistes, vol. 2: 468-469. Leiden: Brill.

Canard, M. 1973. Byzance et les musulmans du Proche Orient. London: Variorum reprints.

Canard, M. 1974. L'expansion arabo-islamique et ses repercussions. London: Variorum Reprints.

Capezzone, L. 1998. La politica ecumenica califfale: pluriconfessionalismo, dispute interreligiose e trasmissione del patrimonio greco nei secoli VIII-IX. In Percorsi e luoghi di trasmissione di idee, ed. B. S. Amoretti Oriente Moderno 17: 1: 1-62.

Capizzi, C. 1994. Giustiniano I tra politica e religione. Soveria Mannelli: Rubbettino.

Carlson, Th. A. 2018. When did the Middle East become Muslim? Trends in the study of Islam's “Age of Conversions." In History Compass 16 (October) 10.1111/hic3.12494 [accessed 22.10.2020].

Carrière, J. M. 1979. Le mystère de Jésus-Christ transmis par Chalcédoine. Nouvelle revue théologique 11: 1: 338-357.

Cassetti, M. A. 1958. Giustiniano e la sua legislazione in material ecclesiastica. Roma: Pontificium Athenaeum Lateranense.

Cecota, B. 2012. Islam, the Arabs and Umayyad Rulers According to Theophanes the Confessor's Chronography. Studia Ceranea 2: 97-111.

Chadwick, H. 1951. Eucharist and Christology in the Nestorian controversy. The Journal of Theological Studies 2: 145-164.

Chadwick, H. 1955. The exile and death of Flavian of Constantinople: a prologue to the Council of Chalcedon. The Journal of Theological Studies 6: $17-34$.

Chaine, M. 1925. La chronologie de l'Égypte et de l'Éthiopie. Paris: Geuthuer. 


\section{Bibliography}

Chalhoub, G. 1999. Recherches sur les Mardaïtes-Ğarāğima. Kaslik: Bibliothèque de l'Université Saint-Esprit.

Charanis, P. 1939. The Religious Policy of Anastasius I, 491-518. Madison: University of Wisconsin Press.

Charles, H. 1936. Le christianisme des arabes nomades sur le limes et dans le désert syro-mésopotamien aux alentours de l'Hégire. Paris: Leroux.

Che, J. 2015. The political and social conflict between Orthodox Christianity (Constantinople and Rome) and Eastern Monophysitism. Athens Journal of History 1: 4: 267-288.

Cheikho, L. 1987. Les vizirs et secrétaires arabes chrétien en islam, 622-1517. Jounieh: Librairie Saint-Paul.

Cheikho, L. 2008. Arabic Christian Poets before and after Islam (Christianity in the Islamic World, No. 1: Facsimile Reprint of Original 1924/1927 Edition). Piscataway NJ: Gorgias Press.

Chesnut, C. R. 1976. Three Monophisite Christologies: Severus of Antioch, Philoxenus of Mabbug and Jacob of Sarug. London: Oxford University Press.

Chitty, D. J. 1966. The Desert a City: An Introduction to the Study of Egyptian and Palestinian Monasticism under the Christian Empire. Oxford: Clarendon Press.

Chitty, D. J. 1980. Et le désert devint une cité ...une introd. à l'étude du monachisme égyptien et palestinien dans l'Empire chrétien. Bégrolles-enMauges: Abbaye de Bellefontaine.

Christides, V. 2016. Religious and social rivalries in Byzantine Egypt on the eve of and during the Arab Conquest (ca. 639-640 CE-ca. 645-646 CE). Pharos Journal of Theology 97: 1-11. http//:www.pharosjot.com [accessed 22.11.2020].

Christides, V. 2017. The decline of the Melkite Church in Islamic Egypt and its revival by Patriarch Cosmas I (ca. 727-768). Pharos Journal of Theology 98: 1-13. https://www.pharosjot.com/uploads/7/1/6/3/7163688/article_5_ vol_98_2017.docx.pdf [accessed 25.10.2020].

Christiensen, T. 1969. Johannes Damaskenos Opgør med Islam. Dansk Theologisk Tiddkrift 32: 34-50.

Chung-Hang Chiu, P. 1987. A Historical Study of Nestorian Christianity in the T'ang Dynasty between A.D. 635-845. Ann Arbor: University microfilms international.

Coates-Stephens, R. 2007. San Saba and the xenodochium de via Nova. Rivista di Archeologia Cristiana 83: 223-256.

Codoñer, J. S. 2013. Melkites and Icon worship during the Iconoclastic period. Dumbarton Oaks Papers 67: 135-187.

Colson, F. H. 1924. Two examples of literary and rhetorical criticism in the fathers. The Journal of Theological Studies 25: 364-377.

Constantelos, D. J. 1972. The Moslem Conquests of the Near East as Revealed in the Greek Sources of the Seventh and Eighth Centuries. Byzantion 42: 325-357.

Corbo, P. V. 1958. L'ambiente materiale della vita dei monaci di Palestina nel periodo bizantino. In Il monachesimo orientale, ed. I. Hausherr. 
Orientalia Christiana Analecta 153: 215-257. Roma: Pont. Inst. Orientalium Studiorum.

Corriente, F. 2007. The Psalter fragment from the Umayyad Mosque of Damascus: a birth certificate of Nabatī Arabic. In Eastern Crossroads: Essays on Medieval Christian Legacy, ed. J. P. Monferrer-Sala, 303-332. Piscataway, New York: Gorgias Press.

Couturier, A. 1930. Cours de Liturgie Grecque-Melkite, vol. 3. Jerusalem: Imprimerie des R.P. Franciscains de Terre Sainte.

Creswell, K. A. C. 1958. A Short Account of Early Muslim Architecture. Baltimore: Penguin Books.

Creswell, K. A. C. 1969. Early Islamic Architecture, vol. 1. Oxford: Oxford University Press.

Crone, P. and Hinds, M. 2003. God's Caliph: Religious Authority in the First Centuries of Islam. Cambridge: Cambridge University Press.

Crone, P. 1980. Islam, Judaeo-Christianity and Byzantine Iconoclasm. Jerusalem Studies in Arabic and Islam 2: 59-95.

Dagron, G. 1999b. Chrześcijaństwo bizantyjskie od VII do połowy XI wieku. Kościół i państwo (połowa IX-koniec X wieku), In Historia chrześcijaństwa. Religia-kultura-polityka, vol. 4: Biskupi, mnisi i cesarze 610-1054, ed. J.-M. Mayer, 145-207. Warszawa: Krupski i S-ka.

Dagron, G. 1999a. Kościół bizantyjski i chrześcijaństwo bizantyjskie między najazdami a ikonoklazmem (VII wiek-początek VIII wieku). In Historia chrześcijaństwa. Religia - kultura - polityka, vol. 4: Biskupi, mnisi i cesarze 610-1054, ed. J.-M. Mayer, 17-85. Warszawa: Krupski i S-ka.

Dauvillier, J. 1953. Byzantins d'Asie Centrale et d'Extrême-Orient au Moyen Âge. Revue des études byzantines 11: 62-87.

Delaruelle, E. 1941. Essai sur la formation de l'idée de croisade. Bulletin de de Littérature Ecclésiastique 42: 24-45.

Delle Rose, M. 1986-1987. "Crudis leguminibus pascebatur". Cellae Novae e S. Saba, fonti e riscontri archeologici. Romanobarbarica 9: 65-113.

Dennett, D. 1950. Conversion and the Poll-Tax in Early Islam. Harvard Historical Monograph 22. Cambridge: Cambridge University Press.

Dermenghem, E. 1955. Mahomet et la tradition islamique. Burges: Éditions du Seuil.

Deroche, V. 2010. Entre Rome et l'Islam. Les chrétientés d'Orient, 610-1054. Paris: Armand Colin.

Desreumaux, A. 1983. Les manuscrits syro-palestiniens pour des comparaisons. In III Symposium Syriacum 1980: Les contacts du monde syriaque avec les autres cultures - Goslar 7-11 Septembre 1980, ed. R. Lavenant. Orientalia Christiana Analecta 221: 341-347.Roma: Pontificium Institutum Orientale.

Devreesse, R. 1942. Arabes-Perses et Arabes- Romains. Lakhmides et Ghassanides. Vivre et Penser, 2e série: 263-307.

Devreesse, R. 1945. Le patriarcat d'Antioche depuis la paix de l'église jusqu'à la conquête arabe. Paris: Lecoffre.

Dib, P. 1930. L'Église maronite, vol. 1: l'Église maronite jusqu'à la fin du Moyen Age. Paris: Letouzey et Ané. 
Dick, I. (=Dīk A.) 1999. Muğādalat Abī-Qurra ma'a al-mutakallimīn alMuslimīn fĩ mağlis al-Halīfa al-Ma'mūn [without place of edition].

Dick, I. (=Dīk A.) 2013. Al-'Alāqāt al-masīhīya al-islāmīya fĩ Sūrīya 'abr 't-tārīh. Ğūniya: al-Maktaba al-Būlusīya.

Dick, I. 1961. La Passion arabe de S. Antoine Ruwah, néo-martyr de Damas (†25 Déc. 799). Le Muséon 74: 109-133.

Dick, I. 1962 Un continuateur arabe de saint Jean Damascène: Théodore Abuqurra, évêque melkite de Harran. La personne et son milieu. ProcheOrient chrétien 12: 209-223; 319-332.

Dick, I. 1994. Les Melkites: grecs-orthodoxes et grecs catholiques des patriarcats d'Antioche, d'Alexandrie et de Jérusalem. Turnhout: Brepols.

Dick, I. 2004. Melkites: Greek Orthodox and Greek Catholics of the Patriarchates of Antioch, Alexandria, and Jerusalem. Nashua: Sophia Press.

Diehl, C. and Marçais, G. (ed.) 1936. Histoire du Moyen Âge, vol. 3: Le Monde oriental de 395 à 1081. Histoire Générale. Paris: PUF.

Donner, F. M. 1981. The Early Islamic Conquests. Princeton: Princeton University Press.

Douaihy, H. 1993. Un théologien maronite: Gibra'il ibn al-Qilā’i. Kaslik: Université Saint-Esprit.

Doucellier, A. 1971. Miroir de l'Islam: Musulmans et Chrétiens d'Orient au Moyen-Âge (VII-XI siècle). Paris: René Julliard.

Doucellier, A. 1996. Chrétiens d'Orient et Islam au Moyen Âge: VII ${ }^{\mathrm{e}}-\mathrm{XV}{ }^{\mathrm{e}}$ siècle. Paris: Armand Collin.

Dowling, Th. E. 1913. The Episcopal Succession in Jerusalem from c. A.D. 30. Palestine Exploration Fund Quarterly Statement 45: 4: 164-177.

Downey, G. 1961. A History of Antioch in Syria from Seleucus to the Arab Conquest. Princeton: Princeton University Press.

Drijvers, H. J. W. 1984. East of Antioch: Studies in Early Syriac Christianity. London: Variorum Reprints.

Drijvers, H. J. W. 1994. The testament of our Lord: Jacob of Edessa's response to Islam. Aram Periodical 1-2: 104-114.

Drijvers, H. J. W. 2002. Heraclius and the Restitutio Crucis: notes on symbolism and ideology. In The Reign of Heraclius (610-641): Crisis and Confrontation, ed. G. J. Reinink and B. H. Stolte, 175-190. Leuven-ParisDudley, MA: Peeters.

Drocourt, N. 2010. Christian-Muslim diplomatic relations: an overview of the main sources and themes of encounter (600-1000). In ChristianMuslim Relations: A Bibliographical History (900-1050), ed. D. Thomas, vol. 2: 29-72. Leiden: Brill.

Ducellier, A. 1996. Chrétiens d'Orient et Islam au Moyen Age: VIIe - XVe siècle. Paris: Colin.

Dussaud, R. 1922. Le temple de Jupiter Damascénien et ses transformations aux époques chréti-enne et musulmane. Syria 3: 219-250.

Dussaud, R. 1955. La pénétration des arabes en Syrie avant l'islam. Paris: Gputhner.

Edde, A.-M., Micheau, F., and Picard, C. 1997. Communautés chrétiennes en pays d'Islam du début du $\mathrm{VII}^{\mathrm{e}}$ siècle. Paris: SEDES. 
Ehrhard, A. 1893. Das griechische Kloster Mâr-Saba in Palästina: seine Geschichte und seine literarischen Denkmäler. Römische Quartalschrift 7: 32-79.

Ekonomou, A. J. 2007. Byzantine Rome and the Greek Popes: Eastern influences on Rome and the papacy from Gregory the Great to Zacharias, A.D., 590-752. Lanham: Lexington Books.

Elsner, J. 2000. The Itinerarium Burdigalense: politics and salvation in the geography of Constantine's Empire. The Journal of Roman Studies 90: 181-195.

Eparchy of Newton. 2020. The Saints of Antioch 2020. Eparchy of Newton, Melkite Catholic Church. https://melkite.org/faith/sunday-scriptures/thesaints-of-antioch [accessed 22.10.2020].

Erdmann, C. 1977. The Origin of the Idea of the Crusade. Princeton: Princeton University Press.

Erhart, V. L. 1996. The Church of the East during the period of the four rightly-guided Caliphs. Bulletin of the John Rylands Library 78: 55-71.

Erismann, C. H. 2014. Catachrestic plural forms. Gregory of Nyssa and Theodore Abū Qurrah on naming and counting essences. British Journal for the History of Philosophy 22: 1: 39-59.

Evans, J. A. S. 1996. The Age of Justinian: The Circumstances of Imperial Power. London: Routledge.

Evans, J. A. S. 2002. The Empress Theodora: Partner of Justinian. Austin: University of Texas Press.

Faivre, J. 1914. Alexandrie. In Dictionnaire d'Histoire et de Géographie Ecclésiastiques, vol. 2: 335-369. Paris: Letouzey et Ané.

Fattal, A. 1958. Le Statut légal des non-musulmans en pays d'Islam. Beirut: Institut de Lettres Orientales de Beyrouth.

Ferrari, G. 1957. Early Roman monasteries: notes for the history of the monasteries and convents at Rome from the $\mathrm{V}$ through the $\mathrm{X}$ century. Studi di Antichità Cristiana, 23. Città del Vaticano: Pontificio Istituto di Archeologia Cristiana.

Ferré, A. 1988. Chrétiens de Syrie et de Mésopotamie au début de l'islam. Islamochristiana 14: 72-102.

Ferré, A. 1996. Protégés ou citoyens? Islamochristiana 22: 79-117.

Fiey, J.-M. 1965. Assyrie chrétienne. Contribution à l'étude de l'histoire et de la géographie ecclésiastiques et monastiques du Nord de l'Iraq, vol. 1-2. Beyrouth: Librairie Orientale.

Fiey, J.-M. 1969. Le pèlerinage des Nestoriens et Jacobites à Jerusalem. Cahiers de civilisation médiévale 12: 46: 113-126.

Fiey, J.-M. 1980. Chrétiens syriaques sous les Abbasides surtout à Bagdad (749-1258). Corpus Scriptorum Christianorum Orientalium, 420. Louvain: Peeters.

Fiey, J.-M. 1987. The last Byzantine Campaign into Persia and Its Influence on the Attitude of the Local Populations Towards the Muslim Conquerors 7-16 AH/628-636 AD. In Proceedings of the Second Symposium on the History of Bilād Al-Shàm during the Early Islamic Period Up to $40 \mathrm{AH} / 640$ AD: The Fourth International Conference on the History of Bilad Al-Shām, 


\section{Bibliography}

Vol. 1: English and French Papers, ed. M. A. Bakhīt, 96-103. Amman: University of Jordan.

Fiey, J.-M. 1993. Nașārā. In The Encyclopaedia of Islam: New Edition, ed. C. E. Bosworth, vol. 7: 970-974. Leiden: Brill.

Fiey, J.-M. 1995. Le sceau sassanide d'un catholicos melkite d'asie centrale. Proche Orient Chrétien 45: 6-9.

Finster, B. 1970-1971. Die Mosaiken in der Umayyadenmoschee von Damaskus. Kunst des Orients 7: 2: 83-141.

Fisher, G. 2014a: Rome and the Ghassanids: comparative perspectives on conversion, boundaries and power in Near Eastern borderlands. In The Levant. Crossroads of Late Antiquity: History, Religion and Archaeology, ed. E. Bradshaw Aitken. McGill University Monographs in Classical Archaeology and History 22: 273-292. Leiden: Brill.

Fisher, G. 2014b: State and tribe in late antique Arabia: a comparative view. In Inside and Out: Interactions between Rome and the Peoples of the Arabian and Egyptian Frontiers, ed. J. H. F. Dijkstra, G. Fisher, 279-295. Leuven: Peeters.

Fisher, G. 2018. Reflections on Arab leadership in late antiquity. In To the Madbar and Back Again: Studies in the Languages, Archaeology and Cultures of Arabia Dedicated to M. C. A. Macdonald, ed. L. Nehme and A. al-Jallad, 489-521. Leiden: Brill.

Flood, F. B. 2001. The Great Mosque of Damascus: Studies on the Makings of an Umayyad Visual Culture. Leiden: Brill.

Foltz, R. C. 1999. Religions of the Silk Road: Overland Trade and Culture Exchange from Antiquity to the Fifteenth Century. London: Macmillan.

Forsyth, J. H.1977. The Byzantine-Arab Chronicle (938-1034) of Yahyā B. Sa‘īd Al-Anțākī. Vol. 1-2. Michigan: University Microfilms. 1268.

Fortescue, A. 1910. Jérusalem. In The Catholic Encyclopedia, ed. Ch. G. Herbermann, vol. 8: 355-364. New York: Robert Appleton Company.

Foss, C. 1975. The Persians in Asia Minor and the End of Antiquity. The English Historical Review 90: 721-747.

Foss, C. 2003. The Persians in the Roman near East (602-630 AD). Journal of the Royal Asiatic Society Third Series 13: 2: 149-170.

Frye, R. N. 1977. Appendix: The Pahlavi Inscriptions on the Seals. In Christian Seals of the Sasanian Period, ed. J. A. Lerner. Istanbul: Nederlands Historisch-Archaeologisch Instituut.

Gabriele, M. 2011. An Empire of Memory: The Legend of Charlemagne, the Franks, and Jerusalem before the First Crusade. Oxford: Oxford University Press.

Gabrieli, F. 1935. Il califfato di Hishâm. Studi di Storta omayyade. Mémoires de la Société royale d'Archéologie d'Alexandrie 7: 2. Alexandrie: Société de Publications Égyptiennes.

Galadza, D. 2013. Sources for the Study of Liturgy in Post-Byzantine Jerusalem (638-1187 CE). Dumbarton Oaks Papers 67: 75-94.

Galadza, D. 2018. Liturgy and Byzantinization in Jerusalem. Oxford: Oxford University Press.

Galtier, P. 1933. De Sanctissima Trinitate in se et in nobis. Parisiis: apud Gabrielem Beauchesne et filos. 
Ganshof, F. L. 1961-1962. Les relations extérieures de la monarchie franque sous les premiers souverains carolingiens. Annali di storia del diritto 5-6: 1-53.

Gardet, L. 1962. La cité musulmane. In Vie sociale et politique. Paris: Librairie Philosophique J. Vrin.

Garitte, A. J. R. 1960. La prise de Jérusalem par les Perses. In Corpus scriptorum Christianorum Orientalium, 202-203. Louvain: Secrétariat du Corpus SCO.

Gascou, J. 1983. De Byzance a l'islam: les impțts en Egypt après la conquète arabe. Journal of the Economic and Social History of the Orient 26: 97-109.

Gatti, C., Karalevskij, C., and Janin, R. 1942. I riti e le chiese Orientali, vol. 1: Il rito bizantino e le chiese byzantine. Genova-Sampierdarena: Libreria Salesiana editrice.

Gaudel, A. 1929. La théorie du Logos chez Saint Athanase. Revue des Sciences Religieuses 9: 4: 524-539.

Gaudeul, J.-M. 1984. The Correspondance between Leo and Umar: Umar's Letter Re-discovered? Islamochristiana 10: 109-157.

Gaudeul, J.-M. 1995. La correspondance de 'Umar et Léon (vers 900). Collection Studi Arabo-islamici del PISAI 6. Roma: Pontificio Istituto di Studi Arabi e d'Islamistica.

Geis, L. 2003. Fremde, Verbündete, Gegner? Muslime und Juden im Verständnis Karls des Großen. In Ex oriente. Isaak und der weiße Elefant: Aachen. Der Westen. 800 und Heute, ed. W. Dreßen, G. Minkenberg, and A. C. Oellers, vol. 3: 78-93. Mainz: von Zabern.

Gero, S. 1973. Byzantine iconoclasm during the reign of Leo III, with particular attention to the oriental sources. Corpus Scriptorum Christianorum Orientalium - Subsidia 41. Louvain: Peeters.

Gibb, H. A. R. 1958. Arab-Byzantine Relations under the Umayyad Caliphate. Dumbarton Oaks Papers 12: 219-233.

Gignoux, P. H. 1978. Catalogue des seaux, comées et bullles sasanides de la Bibliothèque Nationale et du Musée du Lourvre, vol. 2. Paris: Bibliothèque Nationale.

Gil, M. 1992. A History of Palestine, 634-1099. New York: Cambridge University Press.

Gil, M. 1996. The political history of Jerusalem during the early Muslim period. In The History of Jerusalem: The Early Muslim Period (638-1099), ed. J. Prawer, H. Ben Shammai, 1-37. Jerusalem: Yad Ben Zvi.

Gilman, I. and Klimkeit, H. J. 2016. Christians in Asia before 1500. London-New York: Routledge.

Glubb, J. B. 1963. The Great Arab Conquests, London: Hodder \& Stoughton.

Goehring, J. E. 1999. Ascetics, Society, and the Desert: Studies in Early Egyptian Monasticism. Harrisburg: Trinity Press International.

Goeje, M. J. 1900. Mémoire sur la conquête de la Syrie. Leiden: Brill.

Goitein, S. D. 1966. Studies in Islamic History and Institutions. Leiden: Brill. 


\section{Bibliography}

Gouillard, J. 1968. Aux origines de l'iconoclasme: le témoignage de Grégoire II? Travaux et mémoires. Centre de recherches d'histoire et de civilisation byzantines 3: 243-307.

Gouillard, J. 1976. L'Église d'Orient et la primauté romaine au temps de l'iconoclasme. Istina 21: 25-54.

Grabar O. 1977. Islam and Iconoclasm. In Iconoclasm. Papers Given at the 9th Symposium of Byzantine Studies, University of Birmingham, March 1975, ed. A. Bryer and J. Herrin, 45-52. Birmingham: Centre for Byzantine Studies, University of Birmingham.

Grabar, A. 1984. L'iconoclasme byzantin, dossier archéologique, 2e édition revue et augmentee. Paris: Flammarion.

Grabar, O. 1973. The Formation of Islamic Art. New Haven: Yale University Press.

Graboïs, A. 1981. Charlemagne, Rome and Jerusalem. Revue Belge de Philologie et d'Histoire 59: 4: 792-809.

Graf, G. 1954. Verzeichnis arabischer kirchlicher Termini. In Corpus Scriptorum Christianorum Orientalium, 147. Louvain: Peeters.

Graf, G. 1905. Der Sprachgebrauch der ältesten christlisch-arabischen Literatur. In Ein Beitrag zur Geschichte des Vulgär-arabisch. Leipzig: Harrassowitz.

Graf, G. 1911. Ein bisher unbekanntes Werk des patriarchen Eutychius von Alexandrien. Oriens Christianus 1: 227-244.

Graf, G. 1944. Geschichte der christlichen arabischen Literatur, vol. 1: Übersetzungen. Città del Vaticano: Biblioteca apostolica vaticana.

Graf, G. 1947. Geschichte der christlichen arabischen Literatur, vol. 2: Die Schriftsteller bis zum Mitte des 15. Jahrhunderts. Città del Vaticano: Biblioteca apostolica vaticana.

Graf G. 1934. Catalogue de manuscrits arabes chrétiens conservés au Caire. Città del Vaticano: Biblioteca Apostolica Vaticana.

Gregory, T. E. 2005. A History of Byzantium. Malden: Blackwell Pub.

Griffith, S. H. 1987. Free Will in the Christian Kalām: the Doctrine of Theodor Abu Qurra. Parole de l'Orient 14: 79-108.

Griffith, S. H. 1992. Images, Islam, and Christian icons: a moment in the Christian/Muslim encounter in early Islamic times. In La Syrie de Byzance à l'Islam VIIe-VIIIe siècles. Actes du Colloque International Lyon-Maison de l'Orient Mediterranéen, Paris-Institut du Monde Arabe, 11-15 Septembre, ed. P. Canivet and J.-P. Rey-Coquais, 121-138. Damascus: Institut français de Damas.

Griffith, S. H. 1993. Reflections on the biography of Theodore Abu Qurrah. Parole de l'Orient 18: 143-170.

Griffith, S. H. 1994. Michael, the Martyr and Monk of Mār Sābās Monastery, at the Court of the Caliph 'Abd al-Malik; Christian Apologetics and Martyrology in the Early Islamic Period. Aram 6: $115-148$.

Griffith, S. H. 1995. Muhammad and the Monk Bahîrâ: Reflections on a Syriac and Arabic Text from Early Abbasid Times. Oriens Christianus 79: 146-174. 
Griffith, S. H. 1997. Byzantium and the Christians in the World of Islam: Constantinople and the Church in the Holy Land in the Ninth Century. Medieval Encounters 3: 3: 231-265.

Griffith, S. H. 1998. Christians, Muslims, and neo-martyrs; saints' lives and Holy Land history. In Sharing the Sacred; Religious Contacts and Conflicts in the Holy Land, First-Fifteenth Centuries CE, ed. A. Kofsky, 163-207. Jerusalem: Yad Izhak Ben Zvi.

Griffith, S. H. 1999a. Arab Christian culture in the Early Abbasid period. Bulletin of the Royal Institute for Inter-Faith Studies 1: 2: 24-44.

Griffith, S. H. 1999b. The Qur'an in Arab Christian texts: the development of an apologetical argument: Abu Qurrah in the maglis of al-ma'mun. Parole de l'Orient 24: 203-233.

Griffith, S. H. 2001. 'Melkites', 'Jacobites', and the Christological controversies in Arabic in Third/Ninth-Century Syria. In Syrian Christians Under Islam: The First Thousand Years, ed. D. Thomas, 9-55. Leiden: Brill.

Griffith, S. H. 2006. The Church of Jerusalem and the 'Melkites': the making of an 'Arab Orthodox' Christian identity in the World of Islam (750-1050 CE). In Christians and Christianity in the Holy Land: From the Origins to the Latin Kingdoms, ed. O. Limor, G. G. Stroumsa, 174-204. Turnhout: Brepols Publishers.

Griffith, S. H. 2007. Christians, Muslims and the Image of the One God: Iconophilia and Iconophobia in the World of Islam in Umayyad and Early Abbasid Times. In Die Welt der Götterbilder, ed. B. Groneberg and H. Spieckermann. Beihefte zur Zeitschrit für die alttestamentische Wissenschaft 376: 347-380. Berlin-New York: W. de Gruyter.

Griffith, S. H. 2013. The Melkites and the Muslims: the Qur'ān, Christology, and Arab orthodoxy. Al-Qantara 33: 2: 413-443.

Grigss, C. W. 1990. Early Egyptian Christianity: From Its Origins to 451 CE. Leiden: Brill.

Grillmeier, A. 1979. Jesus der Christus im Glauben der Kirche, vol. 1. Freiburg-Basel-Wien: Herder.

Grotz, H. 1964. Die Hauptkirchen des Ostens von dem Anfäng bis zum Konzil von Nikaia, vol. 325. Roma: Pont. Inst. Orientalium Studiorum.

Grumel, V. 1958. Traité d'études Byzantines I. La chronologie. Paris: Presses Universitaires de France.

Grumel, V. 1962. Notes de chronologie patriarcale. Mélanges de l'Université Saint-Joseph 38: 264-275.

Guenther, A. M. 1999. The Christian experience and interpretation of the early Muslim conquest and rule. Islam and Christian-Muslim Relations 10: 3: 363-378.

Guillaume, A. 1925. Theodore Abu Qurra as apologist. The Muslim World 15: 42-51.

Haase, R. M. 1993. Untersuchungen zur Verwaltung des spätrömischen Reiches unter Kaiser Justinian I. (527 bis 565). Stuttgart: Univ., Diss.

Haddad, R. M. 1965. The Orthodox Patriarchate of Antioch and the origins of the Melkite schism. Cambridge: Cambridge University Press. 
Haddad, R. M. 1985. Trinité divine ches les théologiens arabes. Paris: Beauchesne.

Haddad, R. M. 1990. Conversion of Eastern Orthodox Christians to the Unia in the seventeenth to eighteenth centuries. In Conversion and continuity. Indigenous Christian Communities in Islamic Lands. Eighth to Eighteenth Centuries, ed. M. Gervers, R. I. Birkhazi, 449-459. Toronto: Pontifical Institute of Mediaeval Studies.

Haji-Athanasiou, M. 1977-2002. Mawsū'a Batrīarkīya Antākīya al-tārīhiyya wa al-atariyya (Encyclopédie historique et archéologique du Patriarcat d'Antioche), vol. 1-10: 2. Dimašq- Younieh: Librairie St Paul.

Hajjar, J. 1962. Les Chrétiens uniates du Proche Orient. Paris: Éditions du Seuil.

Halphen, L. 1947. Éginhard: Vie de Charlemagne. Paris: Belles Lettres.

Hämel, A. 1924. Französische und spanische Heldendichtung. Neue Jahrbücher für Wissenschaft und Jugendbildung 4: 37-48.

Hammerschmidt, F. 1961. Studies in the Ethiopic Anaphoras. Berlin: Akademie Verlag.

Hanssens, J. M. 1932. Institutiones liturgicae de ritibus orientalibus, vol. 2. Romae: Aedes Pont. Univ. Gregorianae.

Harvey, S. A. 2010. Theodora the "Believing Queen:" a study in Syriac historiographical tradition. Journal of Syriac Studies 4: 1: 209-234.

Hauziński, J. 1993. Burzliwe dzieje kalifatu bagdadzkiego. WarszawaKraków: PWN.

Hefele, K. J. 1907-1952. Histoire des conciles d'après les documents originaux, vol. 1-11. Paris: Letouzey et Ané.

Heijer, J. den 1990. Reflexions sur la composition de l'Histoire des patriarches s'Alexandrie: les auteurs des sources coptes. In Coptic Studies, Acts of the Third International Congress of Coptic Studies: Warsaw, 20-25 August 1984, ed. W. Godlewski, 107-113. Varsovie: PWN.

Heijer, J. D. 1989. Mawhüb ibn Manșür ibn Mufarriğ et l'historiographie copto-arabe: Étude sur la composition de l'Histoire des Patriarches d'Alexandrie. Corpus Scriptorum Christianorum Orientalium Subsidia 83. Louvain: Peeters.

Hill, D. R. 1971. The Termination of Hostilities in Early Arab Conquests A.D., 634-656. London: Luzac.

Hill, D. R. 1975. The role of the camel and the horse in the Early Arab Conquest. In War, Technology and Society in the Middle East, ed. V. J. Parry, M. E. Yapp, 32-43. London: Oxford University Press.

Hill, G. 1940. A History of Cyprus, vol. 1. Cambridge: Cambridge University Press.

Hillenbrand, R. 1994. Islamic Architecture: Form, Function, and Meaning. New York: Columbia University Press.

Hirschfeld, Y. 1992. The Judean Desert Monasteries in the Byzantine Period. New Haven-London: Yale University Press.

Hitti, Ph. K. 1964. History of the Arabs: From the Earliest Times to the Present. London: MacMillan \& Company. 
Hockey, T. (ed.). 2007. The Biographical Encyclopedia of Astronomers. New York: Springer.

Hodgkin, T. 1897. Charles the Great. London: Macmillan.

Honigmann, E. 1951. Evêques et évêchés monophisites d'Asie antérieure au $\mathrm{VI}^{\mathrm{e}}$ siècle. In Corpus Scriptorum Christianorum Orientalium, 127. Louvain: Peeters.

Honigmann, E. 1954. Le couvent de Barsauma et le patriarcat jacobite d'Antioche et de Syrie. In Corpus Scriptorum Christianorum Orientalium, 146. Louvain: Peeters.

Honigmann, E. 1961. Trois mémoires posthumes d'histoire et de géographie de l'Orient chrétien. In Subsidia hagiographica, 35. Bruxelles: Société des Bollandistes.

Honigmann, E. 1947. The Patriarcate of Antioch. A revision of Le Quien and the Notitia Antiochena. Traditio 5: 135-161.

Honigmann, E. 1950. Juvenal of Jerusalem. Dumbarton Oaks Papers 5: 209-279.

Hovorun, C. 2008. Will, Action and Freedom: Christological Controversies in the Seventh Century. Leiden: Brill.

Howard-Johnston, J. 2010. Witnesses to a world crisis. Historians and Histories of the Middle East in the Seventh Century. Oxford: Oxford University Press.

Hoyland, R. G. 1997. Seeing Islam as Others Saw It: A Survey and Evaluation of Christian, Jewish, and Zoroastrian Writings on Early Islam. Princeton: Darwin Press.

Hussein, F. 1982. Das Steuersystem in Ägypten von der arabischen Eroberung bis zur Machtergreifung Tuluniden 639-868 mit besonderer Berücksichtigung der Papyrusurkunden. In Heidelberger orientalistische Studien 3. Frankfurt am Main: Peter Lang.

Innes, M. 1996-1997. The classical tradition and Carolingian historiography: encounters with Suetonius. International Journal of the Classical Tradition 3: 3: 265-282.

Janeres, V. S. 1969. Introductio in liturgias orientales. Romae: Pontificium Institutum Orientalium Studiorum.

Janin, R. 1955. Les Églises orientales et les rites orientaux. Paris: Letouzey \& Ané.

Janosik, D. J. 2016. John of Damascus: First Apologist to the Muslims. Eugene, Oregon: Pickwick Publications.

Jeffery, A. 1944. Ghevond's text of the correspondence between Umar II and Leo III. Harvard Theological Review 37: 269-332.

Jeffery, P. 1994. The earliest Christian chant repertory recovered: the Georgian witnesses to Jerusalem chant. Journal of the American Musicological Society 47: $1-38$.

Jenkins, R. J. 1949. The mission of St Demetrianus of Cyprus to Baghdad. Annuaire de l'Institut de Philologie et d'Histoire Orientales et Slaves, Mélanges Grégoire 9: 267-275.

Jenkins, R. J. H. 1963. A note on the "Letter to the Emir" of Nicholas Mysticus. Dumbarton Oaks Papers 17: 399-401. 


\section{Bibliography}

Jouguet, P. (ed.). 1947. La domination romaine en Egypte aux deux premièrs siècles après Jésus-Christ: conférence donnée à la Société Archéologique d'Alexandrie, le 29 avril 1946. Alexandrie: La Société Archéologique d'Alexandrie.

Jugie, M. 1912. Nestorius et la controverse nestorienne. Paris: Beauchesne.

Kaegi, W. E. 1982. Heraklios and the Arabs. The Greek Orthodox Theological Review 27: 109-133.

Kaegi, W. E. 1992a. Reflexion on the withdrawal of Byzantine armies from Syria. In La Syrie de Byzance à l'Islam VIIe-VIIIe siècles. Actes du Colloque International Lyon-Maison de l'Orient Mediterranéen, Paris- Institut du Monde Arabe, 11-15 Septembre, ed. P. Canivet and J.-P. Rey-Coquais, 265-280. Damascus: Institut français de Damas.

Kaegi, W. E. 1992b. Byzantium and the Early Islamic Conquests. Cambridge: Cambridge University Press.

Karagiannopoulos, I. E. and Weiss, G. 1982. Quellenkunde zur Geschichte von Byzanz (324-1453). Wiesbaden: Harrassowitz.

Karalevskij, C. (=Cyrille Charon) 1909. Histoire de patriarcats melkites depuis le schisme monophysite du $\mathrm{VI}^{\mathrm{e}}$ siècle jusqu'à nos jours, vol. 1 . Rome: Imprimerie du Sénat.

Karalevskij, C. (=Cyrille Charon) 1910. Histoire de patriarcats melkites depuis le schisme monophysite du VI ${ }^{\mathrm{e}}$ siècle jusqu'à nos jours, vol. 2. Rome: Imprimerie du Sénat.

Karalevskij, C. 1924. Antioche. In Dictionnaire d'histoire et de géographie ecclésiastique, ed. A. Baudrillart, vol. 3: 563-703. Paris: Letouzey et Ané.

Kazhdan, A. and Gero, S. 1987. Kosmas of Jerusalem: a more critical approach to his biography. Byzantinische Zeitschrift 82: 1-2: $122-132$.

Keating, S. T. 2006. Defending the 'People of Truth' in the early Islamic period. The Christian apologies of Abū Rā'ițah. The History of ChristianMuslim Relations, 4. Leiden: Brill.

Kennedy, H. 1985. The last century of Byzantine Syria: a reinterpretation. Byzantinische Forschungen 10: 141-185.

Khalidi, T. 1975. Islamic historiography: the histories of Mas 'ùdī. Albany: State University of New York Press.

Khoury, A.-Th. 1969a. Der theologische Streit der Byzantiner mit dem Islam. Paderborn: Schöningh.

Khoury, A.-Th. 1969b. Les Théologiens byzantins et l'Islam. Textes et auteurs $\left(\mathrm{VIII}^{\mathrm{e}}-\mathrm{XIII}{ }^{\mathrm{e}} \mathrm{s}\right)$. Louvain: Neuwelaerts.

Khoury, A.-Th. 1982. Apologétique byzantine contre l'islam (VIIIe-XIIIe siècle). Altenberge: Christlich-Islamisches Schrifttum (CIS) Verlag.

Khoury, P. 1994. Jean Damascène et l'islam. Würzburg: Echter Verlag.

Kilpatrick, H. 2003. Monasteries through Muslim eyes: the Diyārāt books. In Christians at the heart of Islamic rule Church life and scholarship in 'Abbasid Iraq, ed. D. Thomas, 19-37. Leiden-Boston: Brill.

Kilpatrick, H. 2017. The Arabic Culture of Christians in Syria in the 16th and 17th centuries. In Contacts and Interaction: Proceedings of the 27th Congress of the Union Européenne des Arabisants et Islamisants, Helsinki 
2014, ed. J. Hämeen-Anttila, P. Koskikallio, and I. Lindstedt, 221-232. Leuven-Paris-Bristol: Peeters Publishers.

Kilpatrick, H. 2019. From Venice to Aleppo: Early Printing of Scripture in the Orthodox World. Chronos 30: 33-61.

King, M. O. 1966. Joannis Damasceni "De Haeresibus” cap. CI and Islam. Studia Patristica 7: 76-81.

Klein, W. 1999. Das Orthodoxe Katholikat von Romagyris in Zentralasien. Parole de l'Orient 24: 235-265.

Klein-Franke, F. 1982. Vorlesungen über die Medizin im Islam. Sudhoffs Archiv, 23. Wiesbaden: Steiner.

Kłoczowski, J. 1964. Wspólnoty chrześcijańskie. Kraków: Znak.

Kościelniak, K. 2000a. XX wieków chrześcijaństwa w kulturze arabskiej, vol. 1: Arabia starożytna. Chrześcijaństwo w Arabii do Mahometa. Kraków: Wydawnictwo Unum.

Kościelniak, K. 2000b. Pluralizm Kościoła katolickiego w Egipcie wczoraj i dziś. Saeculum Christianum 7: 35-55.

Kościelniak, K. 2000c. Akulturacja muzułmańska i arabizacja chrześcijan. Kultura i religia na Bliskim Wschodzie w pierwszych wiekach islamu według Ibn Hualdūna (1332-1406). Analecta Cracovienisa 32: 289-306.

Kościelniak, K. 2001a. Dynamizm akulturacji muzułmańsko-chrześcijańskiej w pierwszych wiekach islamu na Bliskim Wschodzie. Saeculum Christianum 9: 1-19.

Kościelniak, K. 2001b. Tradycja muzułmańska na tle akulturacji chrześcijańsko-islamskiej od VII do X wieku. Kraków: Unum.

Kościelniak, K. 2002a. Chrześcijaństwo wobec podbojów muzułmańskich do wypraw krzyżowych. In $W$ kręgu cywilizacji Półksiężyca. 6. Ogólnopolska Konferencja Arabistyczna Kraków, 14-15 maja 2002, ed. B. Michalak-Pikulska, 195-207. Kraków: Wydawnictwo Uniwersytetu Jagiellońskiego.

Kościelniak, K. 2002b. Polemika muzułmańsko-chrześcijańska na podstawie korespondencji przypisywanej kalifowi umajjadzkiemu 'Umarowi II (zm. 720) i cesarzowi bizantyjskiemu Leonowi III (zm. 741). Folia Historica Cracovienisa 8: 97-105.

Kościelniak, K. 2003. Chrześcijańskie piśmiennictwo arabskie przed Mahometem i jego wpływ na islam. Analecta Cracoviensia 35: 329-343.

Kościelniak, K. 2004. Quelques remarques sur la littérature pré-islamique arabe chrétienne. Rocznik Orientalistyczny 57: 69-76.

Kościelniak, K. 2013. Czas i historia w islamie. Kalendarz i podstawy chronologii muzułmańskiej. Kraków: Księgarnia Akademicka.

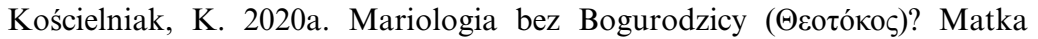
Jezusa w tradycji wschodnio-syriackiej (nestoriańskiej) starożytnego Kościoła Wschodu. In Maryja i Kościót, ed. A. Napiórkowski, 69-90. Kraków: Uniwersytet Papieski Jana Pawła II.

Kościelniak, K. 2020b. A Battle or a Campaign? Historical Facts about the Battle of Al-Qādisiyya (636/637?) and the Role of Story-tellers in the Origin of its Narratives. Rocznik Orientalistyczny 73: 1: 24-40.

Kötter, B. 1959. Die Überliferung der Page Gnoseos des Hl. Johannes von Damascus. Ettal: Buch-Kunstverlag. 
Kötter, J.-M. 2013. Zwischen Kaisern und Aposteln. Das Akakianische Schisma (485-519) als kirchlicher Ordnungskonflikt der Spätantike. Stuttgart: Franz Steiner Verlag.

Krautheimer, R. 1937. Corpus Basilicarum Christianarum Romae (IV-IX). Part IV. Rome: Pontificio istituto di archeologia Cristiana.

Kyrris, C. P. 1984. The Nature of the Arab-Byzantine Relations in Cyprus from the Middle of the 7th to the Middle of the 10th Century A.D. GraecoArabica 3: 149-175.

Labib, S. Y. 1991. Khā̄îl I. In The Coptic Encyclopaedia, ed. A. S. Atiya, vol. 5: 1410-1412. New York: Macmillan, Toronto: Collier Macmillan Canada, New York: Maxwell Macmillan International.

Lamiński, A. 1969. Der Heilige Geist als Geist Christi und Geist der Gläubigen. Der Beitrag des Athanasius von Alexandrien zur Formulierung des trinitarischen Dogmas im Vierten Jahrhundert. Erfurter theologische Studien, 23. Erfurt: St Benno-Verlag.

Lammens, H. 1921a. La Syrie. Précis historique, vol. 1. Beyrouth: Imprimerie Catholique.

Lammens, H. 1921b. Le califat du Yazîd I. Beyrouth: Imprimerie Catholique.

Lammens, H. 1930. Études sur les siècles Omayyades. Beyrouth: Imprimerie Catholique.

Lamoreaux, J. 1996. Early eastern Christian responses to Islam. In Medieval Christian Perceptions of Islam ed. J. V. Tolan, 3-31. London-New York: Routledge.

Lamoreaux, J. C. 2009. "Theodore Abū Qurra". In Christian-Muslim Relations. A Bibliographical History, ed. D. Thomas and B. Roggema, vol. 1: 408. Leiden: Brill.

Lapidus, I. M. 1982. The Arab conquests and the formation of Islamic society. In Studies on the First Century of Islamic Society, ed. G. H. A. Juynboll. Papers on Islamic history 5: 49-72. Carbondale: Southern Illinois University Press.

Latowsky, A. 2005. Foreign Embassies and Roman Universality in Einhard's Life of Charlemagne. Florilegium 22: 25-57.

Lawrence, I. C. 1991. Yahyā of Antioch. In The Oxford Dictionary of Byzantium, ed. A. Kazhdan, vol. 3: 2213. New York-Oxford: Oxford University Press.

Le Coz, R. 1995. Histoire de l'Église d'Orient. Paris: Éditions du Cerf.

Lebon, J. 1946. Autour du cas de Diodor d'Alexandrie. Le Muséon 49: 515-528.

Leclerc, L. 1876. Histoire de la Médicine Arabe: Exposé Complet des Traductions du Grec, les Sciences en Orient, leur Transmission à l'Occident par les Traductions Latines, vol. 1. Paris: Ernest Leroux.

Leeming, K. 2003. The Adoption of Arabic as a Liturgical Language by the Palestinian Melkites. ARAM Periodical Volume 15: 239-246.

Leppin, H. 2003. Theodosius der Grosse. Darmstadt: Primus in Wissenschaftliche Buchgesellschaft.

Leroy, J. 1958. Moines et monastères du Proche-Orient. Paris: Horizons de France. 
Leszka, M. J. and Wolińska, T. 2011. Konstantynopol Nowy Rzym. Miasto i ludzie w okresie wczesnobizantyjskim. Warszawa: Wydawnictwo Naukowe PWN.

Levtzion, N. 1990. Conversion to Islam in Syria and Palestine and the Survival of Christian Communities. In Conversion and Continuity. Indigenous Christian Communities in Islamic Lands. Eighth to Eighteenth Centuries, ed. M. Gervers and R. I. Birkhazi, 289-312. Toronto: Pontifical Institute of Mediaeval Studies.

Levy-Rubin, M. 2000. New evidence relating to the process of Islamization in Palestine in the early Muslim period - the case of Samaria. Journal of the Economic and Social History of the Orient 43: 257-276.

Levy-Rubin, M. 2003. The reorganisation of the Patriarchate of Jerusalem during the Early Muslim Period. ARAM Periodical Volume 15: 197-226.

Levy-Rubin, M. 2016. 'Umar II's ghiyār Edict: Between Ideology and Practice. In Christians and Others in the Umayyad State, ed. A. Borrut and F. M. Donner, 157-172. Chicago: Oriental Institute of the University of Chicago.

Liébaert, J. 1951. La doctrine christologique de saint Cyrille avant la querelle nestorienne. Lille: Facultés catholiques.

Liébaert, J. 1970. L'évolution de la christologie de saint Cyrille à partir de la controverse nestorienne. Mélanges de science religieuse 27: 27-48.

Liébaert, J. 1977. Saint Cyrille et l'unique prosopon du Christ aux origines de la controverse nestorienne. Mélanges de science religieuse 34: 49-62.

Lieu, S. 1986. Captives, refugees, and exiles: a study of cross-frontier civilian movements and contacts between Rome and Persian from Valerian to Jovian. In The Defence of the Roman and Byzantine East, ed. P. Freeman and D. Kennedy, vol. 2: 475-505. Oxford: BAR.

Livne-Kafri, O. 1996. Early Muslim Ascetics and the World of Christian Monasticism. Jerusalem Studies in Arabic and Islam 20: 105-129.

Løkkegaard, F. 1950. Islamic Taxation in the Classic Period. Copenhagen: Branner \& Korch.

Loofs, F. 1914. Nestorius and His Place in the History of Christian Doctrine. Cambridge: Cambridge University Press.

Louth, A. 2002. St John Damascene: Tradition and Originality in Byzantine Theology (Illustrated ed.). Oxford: Oxford University Press.

Louth, A. 2003. Three Treatises on the Divine Images. Crestwood, New York: St Vladimir's Seminary Press.

Louth, A. 2005. St John Damascene: Tradition and Originality in Byzantine Theology. Oxford: Oxford University Press.

Luibheid, C. 1976. The Arianism of Eusebius of Nicomedia. Irish Theological Quarterly 43: 1: 3-23.

Mai, A. 1825. Scriptorum veterum nova collection e vaticanis codicibus. Roma: In Collegio Urbano apud Burliaeum.

Maksymiuk, K. 2017. Destruction of the Ādur Gušnasp temple in Ādurbādagān as a revenge for abduction of the Holy Cross from Jerusalem in the context of the letters of Heraclius. Метаморфозы истории 9: $109-125$. 


\section{Bibliography}

Mango, C. 1978. Who wrote the Chronicle of Theophanes? Zborknik Radova Vizantinoškog Instituta 18: 9-18.

Maséro, J. 1923. Histoire des patriarches d'Alexandrie. Paris: Librairie ancienne.

Massignon, L. 1942. La politique islamo-chrétienne des scribes nestoriens de Deir Qunna à la cour de Bagdad au $\mathrm{IX}^{\mathrm{e}}$ siècle de notre ère. Vivre et penser 2: 7-14.

Mayerson, Ph. 1964. The First Muslim Attacks on Southern Palestine (A.D. 633-634). Transactions and Proceedings of the American Philological Association 95: 155-199.

Mazal, O. 2001. Justinian I und seine Zeit: Geschichte und Kultur des Byzantinischen Reiches im 6. Jahrhundert. Köln: Böhlau Verlag.

McKitterick, R. 1983. The Frankish kingdoms under the Carolingians, 751-987. London: Longman.

Meier, M. 2004. Justinian: Herrschaft, Reich und Religion. München: Beck.

Menges, H. 1938. Die Bilderlehre des hl. Johannes von Damascus. Münster: Aschendorff.

Merill, J. E. 1951. On the tractate of John of Damascus on Islam. Muslim World 41: 88-97.

Meyendorff, J. 1984. Teologia bizantyjska. Historia i doktryna. Warszawa: Instytut Wydawniczy Pax.

Michaelidis, E. 1934. Eutychios Alexandreias. Ekklesiastikos Pharos 33: 7-27; 209-238; 344-365.

Millar, F. 1971. Paul of Samosata, Zenobia and Aurelian: the church, local culture and political allegiance in third-century Syria. The Journal of Roman Studies, 61: 1-17.

Miller, D. H. 1974. The Roman Revolution of the eighth century: a study of the ideological background of die Papal separation from Byzantium and alliance with the Franks. Mediaeval Studies 36: 79-133.

Milne, J. G. 1924. Egypt under Roman Rule. London: Methuen \& Co.

Möennich, C. W. 1950. De achtergrond van de arianse christologie. Nederlandse theologische tijdschrift 4: 378-412.

Monferrer Sala, J. P. 2005. "Apologética racionalista" de Abu Qurrah en el "Maymar fi Wubud al-Haliq wa-l-din al-qawim" II/2, 12-14. Anales Del Seminario de Historia de la Filosofía 22: 41-56.

Monferrer-Sala, J. P. 2012. Between Hellenism and Arabicization. On the formation of an ethnolinguistic identity of the Melkite communities in the heart of Muslim rule. Al-Qanțara 33: 2: 445-471.

Moorhead, J. 1994. Justinian. London, New York: Longman.

Moosa, M. 1969. The relation of the Maronites of Lebanon to the Mardaites and Al-Jarājima. Speculum 44: 4: 597-608.

Mor, M. 2016. The Second Jewish Revolt, The Bar Kokhba War, 132-136 CE. The Brill Reference Library of Judaism, 50. Leiden: Brill.

Morabia, A. 1993. Le Ğihâd dans l'Islam médiéval: le "combat sacré" dès origines au XIIe siècle. Paris: Albin Michel.

Morimoto, K. 1979. Taxation in Egypt under the Arab conquest. Orient 15: 71-99 https://www.jstage.jst.go.jp/article/orient1960/15/0/15_0_71/_pdf [accessed 22.10.2020]. 
Morimoto, K. 1981. The Fiscal Administration of Egypt in the Early Islamic Period. Kyoto: Dohosha.

Morony, M. G. 2010. Michael the Syrian as a source for economic history. Journal of Syriac Studies 3: 2: 141-172.

Morony, M. G. 2004. Population transfers between Sasanian Iran and the Byzantine empire. In La Persia e Bisanzio: convegno internazionale (Roma, 14-18 ottobre 2002. Atti dei convegni lincei), vol. 201: 161-179. Rome: Accademia Nazionale dei Lincei.

Morse, R. 1991. Truth and Convention in the Middle Ages: Rhetoric, Representation, and Reality. Cambridge: Cambridge University Press.

Mouton, J.-M. 1998. Les musulmans à Sainte-Catherine au Moyen Âge. In Le Sinaï durant l'antiquité et le Moyen Âge: 4000 ans d'histoire pour un désert; actes du Colloque "Sinaï" qui s'est tenu à l'UNESCO du 19 au 21 septembre 1997, ed. D. Valbelle and Ch. Bonnet, 177-182. Paris: Errance.

Mubasher, H. 2018. Review: "John Andrew Morrow. The Covenants of the Prophet Muhammad with the Christians of the World". Islamic Studies 57: 3-4: 313.

Müller, C. D. G. 1959a. Benjamin I. In The Coptic Encyclopaedia, ed. A. S. Atiya, vol. 2: 375-377. New York: Maxwell Macmillan International.

Müller, C. D. G. 1959b. Neues über Benjamin I, 38. und Agathon, 39. Patriarchen von Alexandrien. Le Muséon 72: 323-347.

Müller, C. D. G. 1967. Kirche und Mission unter den Arabern in vorislamischer Zeit. Sammlung gemeinverständlicher Vorträge und Schriften aus dem Gebiet der Theologie und Religionsgeschichte, 249. Tübingen: Mohr.

Munshar, M. Y. 2012. Islamic Jerusalem and Its Christians: A History of Tolerance and Tensions. London: Tauris.

Musset, H. 1948. Histoire du christianisme spécialement en Orient, vol. 2. Harrisa: Imprimerie Saint Paul.

Nagel, T. 1981. Staat und Glaubensgemeinschaft im Islam, vol. 1-2. Zürich: Artemis-Verlag.

Nallino, M. 1950. La littérature arabe des origines à l'époque de la dynastie Umayyade: leçons professées en arabe à l'Université du Caire. Paris: G. P. Maisonneuve.

Nasrallah, J. 1950. Saint Jean de Damas-Son époque-Sa vie-Son oeuvre. Harissa: Imprimerie St Paul.

Nasrallah, J. 1970. Catalogue des manuscrits du Liban, vol. 4. Harissa: Imprimerie St Paul.

Nasrallah, J. 1974. Syriens et Suriens. In Symposium Syriacum 1972 célebré dans les jours 26-31 octobre 1972 à l'Institut Pontifical Oriental de Rome, 487-503. Rome: Pontificium Institutum Orientalium Studiorum.

Nasrallah, J. 1976a. Église melchite et Union des Églises. Paris: Centre d'Études Istina.

Nasrallah, J. 1976b. L'Église Melchite en Iraq, en Perse et dans l'Asie Centrale. Jerusalem [s.n.].

Nasrallah, J. 1978. Les historiens musulmans source de d'histoire de l'Église melchite. Bulletin d'études orientales 30: 101-117. 


\section{2}

Bibliography

Nasrallah, J. 1985. Damas et la Damascène: leur églises à l'époque byzantine. Proche-Orient chrétien 35: 1-2: 37-58; 35: 3-4: 264-276.

Nasrallah, J. 1992. De la cathédral de Damas à l'Islam à la mosquée omayyade. In La Syrie de Byzance à l'Islam VIIe-VIIIe siècles. Actes du Colloque International Lyon-Maison de l'Orient Mediterranéen, Paris-Institut du Monde Arabe, 11-15 Septembre, ed. P. Canivet and J.-P. Rey-Coquais, 139-144. Damascus: Institut français de Damas.

Nasrallah, J. and Haddad, R. 1979. Histoire du mouvement littéraire dans l'Église Melchite $\mathrm{du} \mathrm{V}^{\mathrm{e}}$ au $\mathrm{XX}^{\mathrm{e}}$ siècle. Contribution à l'étude de la littérature arabe chrétienne 634-750, vol. 2: 2. Louvain: Peeters.

Nasrallah, J. and Haddad, R. 1996a. Histoire du mouvement littéraire dans l'Église Melchite du $\mathrm{V}^{\mathrm{e}}$ au $\mathrm{XX}^{\mathrm{e}}$ siècle. Contribution à l'étude de la littérature arabe chrétienne 634-750, vol. 2: 1. Louvain: Peeters.

Nasrallah, J. and Haddad, R. 1996b. Histoire du mouvement littéraire dans l'Église Melchite du $\mathrm{V}^{\mathrm{e}}$ au $\mathrm{XX}^{\mathrm{e}}$ siècle. Contribution à l'étude de la littérature arabe chrétienne 634-750, vol. 2: 2. Louvain: Peeters.

Nasry, W. 2007. Abu Qurrah, Al-Ma'mun and Yahya Ibn Aktam. Parole de l'Orient 32: 285-290.

Nassif, B. A. 2005. Religious dialogue in the eighth century: example from Theodore Abu Qurrah Treatise. Parole de l'Orient 30: 333-340.

Nau, F. 1933. Les Arabes chrétiens de Mésopotamie et de la Syrie du VII ${ }^{\mathrm{e}}$ au VIII $^{\mathrm{e}}$ siècle. Paris: Imprimerie Nationale.

Nicolle, D. 2009. The Great Islamic Conquests AD 632-750. Osprey Essential Histories Series, vol. 71. Osprey Publishing.

Nikolaou, S. 2017. A Survey of Byzantine Responses to Islam. In Answering Islam. A Christian_Muslim Dialog. http://64.71.77.248/answering_islam/ history/byzantine_responses.html [accessed 22.10.2020].

Noret, J. 2003. Clavis Patrum Graecorum, vol. 3. Turnhout: Brepols.

Ohme, H. 2008. Oikonomia im monenergetisch-monotheletischen Streit. Zeitschrift für antikes Christentum 12: 308-334.

Ohme, H. 2015. Die Bedeutung der Geschichtstheologie im monenergetischmonotheletischen Streit, des 7. Jahrhunderts. Zeitschrift für Theologie und Kirche 112: 27-61.

Oikonomides, N. 1972. Les listes de presence Byzantines du IX ${ }^{\mathrm{e}}$ et $\mathrm{X}^{\mathrm{e}}$ siècles. Paris: Editions du Centre national de la recherche scientifique.

Onişor, R. 2013. Jerusalem in the time of Constantine the Great. In Religion \& Politics: The Church-State Relationship: From Constantine the Great to PostMaastricht Europe. Proceedings of 12th International Symposium on Science, Theology and Arts ISSTA 2013, Alba Iulia, 14-16 May 2013, ed. M. J. Cherry, D. A. Vanca, and A. Albu, vol. 1: 183-198. Alba Iulia: Editura Reîntregirea.

Ortiz de Urbina, I. 1953. Il dogma di Efeso. Revue des études byzantines 11: 233-240.

Ortiz de Urbina, I. 1964. Nizäa und Konstantinopel. Mainz: Grünwald.

Ostrogorsky, G. 1939. Studien zur Geschichte des byzantinischen Bilderstreites. Breslau: M. and H. Marcus.

Pallikunnil, J. K. 2017. The Eucharistic Liturgy: A Liturgical Foundation for Mission in the Malankara Mar Thoma Syrian Church. UK: AuthorHouse. 
Papaconstantinou, A. 2006. Historiography, Hagiography, and the Making of the Coptic "Church of the Martyrs" in Early Islamic Egypt. Dumbarton Oaks Papers 60: 65-86.

Papadopoulos, Ch. 2009. Historia tes Ekklesias Alexandreias (62-1934). Thessaloniki: P. Pournara.

Papadopoulos-Kerameus, A. 1884. Ho en Kōnstantinupolei Hellēnikos philologikos syllogos: Maurogordateiō bibliothēkē, vol. 18 (supplement). Kōnstantinupolei: Typois S. T. Butyra.

Pargoire, J. 1908. Église d'Alexandrie. In Dictionnaire de théologie catholique, ed. A. Vacant, vol. 1: 786-801. Paris: Letouzey et Ané.

Pargoire, J. 1971. L'Église byzantine de 527 a 847. New York: B. Franklin.

Parry, K. 2012. Byzantine-Rite Christians (Melkites) in Central Asia in Late Antiquity and the Middle Ages. Modern Greek Studies 16: 91-108.

Patriarchate of Alexandria. 2011. The Greek Orthodox Patriarchate of Alexandria and All Africa (2011). http://www.patriarchateofalexandria. $\mathrm{com} /$ index.php? module $=$ content $\&$ cid $=001003 \& \mathrm{id}=124 \&$ lang $=$ en $[$ accessed 22.11.2020].

Patrich, J. 1994. Sabas, Leader of Palestinian Monasticism: A Comparative Study in Eastern Monasticism Fourth to Seventh Centuries. Washington: Dumbarton Oaks Research Library and Collection.

Paulsen, H. 1979. Studien zur Theologie des Ignatius. Göttingen: Vandenhoeck \& Ruprecht.

Pazdernik, Ch. 1994. Our Most Pious Consort Given Us by God: Dissident Reactions to the Partnership of Justinian and Theodora, A.D. 525-548. Classical Antiquity 13: 2: 256-281.

Pelliot, P. 1914. Chrétiens d'Asie centrale et d'Extrême-Orient. T'oung Pao 15: 623-644.

Pelliot, P. 1973. Recherches sur les chrétiens d'Asie centrale et d'ExtrêmeOrient. Paris: Imprimerie Nationale.

Person, R. E. 1978. The Mode of Theological Decision Making at the Early Ecumenical Council. An Inquiry into the Function of Scripture and Tradition at the Councils of Nicea and Ephesus. Theologische Dissertationen, vol. 14. Basel: Basel Univ Diss.

Peeters, P. 1912. S. Antoine le néo-martyr. Analecta Bollandiana 31: 410-450.

Peeters, P. 1930. La Passion de S. Michel le Sabaïte. Analecta Bollandiana 48: 1-2: 65-98.

Peteers, P. 1939. La Passion de S. Pierre de Capitolias (+13 janvier 715). Analecta Bollandiana 57: 299-333.

Peters, F. E. 1986. Jerusalem and Mecca: The Typology of the Holy City in the Near East. New York: New York University Press.

Peters, G. 2011. Peter of Damascus: Byzantine Monk and Spiritual Theologian (Studies and Texts). In Studies and Texts, vol. 175. Toronto: Pontifical Institute of Mediaeval Studies.

Pettersen, A. 1990. Sending Heretics to Coventry? Ignatius on Reverencing Silent Bishops. Vigiliae Christianae 44: 4: 335-350.

Phares, W. 1995. Lebanese Christian Nationalism: The Rise and Fall of an Ethnic Resistance. Boulder-London: Lynne Rienner Publishers. 


\section{Bibliography}

Pinckney, S. 2016. Al-Akhțal at the Court of 'Abd al-Malik: The Qașīda and the Construction of Umayyad Authority. In Christians and Others in the Umayyad State, ed. A. Borrut and F. M. Donner, 128-155. Chicago: Oriental Institute of the University of Chicago.

Pizzo, P. 1998. L'islam e musulmani nella difesa delle icone di Teodoro Abu Qurrah. Parole de l'Orient 22: 667-676.

Pohlsander, H. A. 1980. Philip the Arab and Christianity. Zeitschrift für Alte Geschichte 29: 4: 463-473.

Prévost, L. 1937. Le Sinaï hier-aujourd'hui. Étude topographique, biblique, historique, archéologique. Paris: Éditions P. Lethielleux.

Przekop, E. 1984. Wschodnie patriarchaty starożytne. Warszawa: PAX.

Pummer, R. 2002. Early Christian Authors on Samaritans and Samaritanism. Tübingen: Mohr Siebeck.

Putman, H. 1975. L'Église et l'islam sous Timothée I (780-823): étude sur l'église nestorienne au temps des premiers 'Abbasides avec nouvelle édition et traduction du dialogue entre Timothée et al-Mahdi. Beyrouth: Dar elMachreq.

Qāộ̄ W. (al-) 2016. Non-Muslims in the Muslim conquest army in early Islam. In Christians and Others in the Umayyad State, ed. A. Borrut and F. M. Donner, 83-127. Chicago: Oriental Institute of the University of Chicago.

Raes, A. 1962. Introductio in Liturgiam orientalem. Romae: Pont. Inst. Studiorum Orientalum.

Ramaḍān, A. 2019. Arab apostates in Byzantium: evidence from Arabic

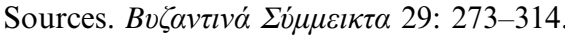

Randa, E. W. 1992. The Tulunid Dynasty in Egypt: Loyalty and State Formation during the Dissolution of the Abbasid Caliphate. University of Utah: Dissertation, Manuscript.

Richard, J. 1990. Le soutien de l'Église latine aux chrétiens d'Orient durant le Moyen Âge. In Conversion and continuity. Indigenous Christian Communities in Islamic Lands. Eighth to Eighteenth Centuries, ed. M. Gervers and R. I. Birkhazi, 389-406. Toronto: Pontifical Institute of Mediaeval Studies.

Ritter, H. 1960. Abū Tammām. In Encyclopédie de l'lslam, nouvelle. Établie avec le concours des principaux orientalistes, vol. 1: 157-159. Leiden: Brill.

Roey, A. 1953. Les débuts de l'Église jacobite. In Das Konzil von Chalkedon. Geschichte und Gegenwart, ed. A. Grillmeier and H. Bacht, vol. 2: 339-360. Würzburg: Echter Verlag.

Roggema, B. 2009. The affair of the death of Muhammad. In ChristianMuslim Relations: A Bibliographical History, ed. D. Thomas and B. Roggema, vol. 1: 401-402. Leiden: Brill.

Roggema, B. 2018. 'Abdisho' bar Bahrīz. In Gorgias Encyclopedic Dictionary of the Syriac Heritage: Electronic Edition, ed. S. P. Brock, A. M. Butts, G. A. Kiraz, and L. Van Rompay. https://gedsh.bethmardutho.org/Abdishobar-Bahriz?fq=;fq-Browse:Browse;C [accessed 22.10.2020].

Rolandus, J. 1977. Le Christ et l'homme dans la théologie d'Athanase d'Alexandrie, Studies in the History of Christian Traditions, vol. 4. Leiden: Brill.

Rosen-Ayalon, M. 1996. Art and architecture in Jerusalem in the early Islamic period. In The History of Jerusalem: The Early Muslim Period 
638-1099, ed. J. Prawer and H. Ben-Shammai, 386-411. Jerusalem: New York University Press.

Rotman, Y. 2009. Byzantine Slavery and the Mediterranean World. Cambridge. MA: Harvard University Press.

Rouhana P. 1988-1989. Identité ecclésiale maronite des origines à la veille du Synode libanais. Parole de l'Orient 15: 215-259.

Rouche, M. 1979. L'Aquitaine des Wisigoths aux Arabes, 418-781. Paris: Ed. de l'Ecole des Hautes Etudes en Sciences Sociales et Jean Touzot.

Rusell, J. R. 1991. Christianity in Pre-Islamic Persia: Literary Sources. In Encyclopadia Iranica, vol. 5: 5: 327-328. Costa Mesa: Mazda Publishing. Ryckmans, J. 1956. La pérsecution des chrétiens himyarites au sixiè me siècle. Istanbul: Uitgaven van het Nederlands Historisch-Archeologisch Instituut.

Šagi-Bunić, T. 1962. Documentatio doctrinalis Ephesino-Chalcedonensis. Laurentianum 3: 499-514.

Šagi-Bunić, T. 1969. Problemata christologiae Chalcedonensis. Continuitas doctrinalis et drama conscientiae episcoporum qua fidei iudicum. Roma: Laurenitianum.

Sahas, D. J. 1996. Eighth-century Byzantine anti-Islamic literature: context and forces. Byzantinoslavica 57: 229-238.

Sahas, D. J. 2003. The demonizing force of the Arab conquests: the case of Maximus (ca. 580-662). Jahrbuch der Österreichischen Byzantinistik 53: 97-116.

Sahas, D. J. 2013. The Oriental character of the Byzantine-Islamic relations: one essence-various expressions. In Byzantium and the Arab. Encounter of Civilizations, International Symposium Proceedings (Thessaloniki, 16-18 December 2011), ed. A. Kralides and A. Gkoutziokostas, 381-404. Thessalonikí: Aristotéleio Panapistímio.

Sahas, D. J. 1972. John of Damascus on Islam. Leiden: Brill.

Sahas, D. J. 1990. The art and non-art of Byzantine polemics. Patterns of refutation in Byzantineanti-Islamic literature. In Conversion and continuity. Indigenous Christian Communities in Islamic Lands. Eighth to Eighteenth Centuries, ed. M. Gervers and R. I. Birkhazi, 55-73. Toronto: Pontifical Institute of Mediaeval Studies.

Sahas, D. J. 1999. Why did Heraclius not defend Jerusalem, and fight the Arabs? Echos d'Orient. Revue d'histoire de géographie et de liturgie orientales 24: 79-97.

Sahas, D. J. 2006. The face to face encounter between Patriarch Sophronius of Jerusalem and the Caliph 'Umar Ibn Al-Khattāab: friends or foes? In The Encounter of Eastern Christianity with Early Islam, ed. E. Grypeou, M. Swanson, and D. Thomas. The History of Christian-Muslim Relations 5: 33-44. Leiden: Brill.

Sahas, D. J. 2009. Sophronius, Patriarch of Jerusalem, "the sophist". In Christian-Muslim Relations. A Bibliographical History, ed. D. Thomas and B. Roggema, vol. 1: 120-127. Leiden: Brill.

Sahner, Ch. C. 2018. Christian Martyrs under Islam: Religious Violence and the Making of the Muslim World. Princeton \& Oxford: Princeton University Press. 


\section{Bibliography}

Sahner, Ch. C. 2020. Martyrdom and conversion. In Christian-Muslim Relations. A Bibliographical History, vol. 15: Thematic Essays (600-1600), ed. D. Pratt and Ch. L. Tieszen, 389-412. Leiden: Brill.

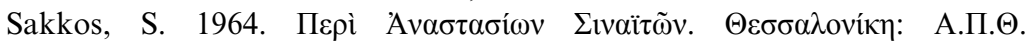

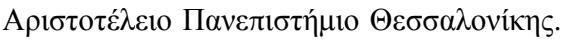

Salaville, S. 1918. L'affaire de l'Hénotique ou le prémiere schisme byzantin au $\mathrm{V}^{\mathrm{e}}$ siècle. Revue des études byzantines Année 114: 255-265.

Salaville, S. 1920. L'affaire de l'Hénotique ou le prémiere schisme byzantin au $\mathrm{V}^{\mathrm{e}}$ siècle. Revue des études byzantines Année 117: 49-68.

Salimi, A. 2014. Inter-religious Dialogue and Debate in Classical Islam: ibn Kammuna's Cultural Model. Journal of Textual Reasoning 8: Narrative, Textuality, and the Other: http://jtr.shanti.virginia.edu/volume-8-number1/inter-religious-dialogue-and-debate-in-classical-islam-ibn-kammunascultural-mode [accessed: 12.11.2020].

Samir, K. 1980. Le traité de l'unité de Yahyā Ibn 'Adī (893-974). Étude et édition critique. Roma: Pontificium Institutum Orientalium Studiorum.

Samir, K. 1981. Liberté religieuse et propagation de la foi chez les théologiens arabes chrétiens. du IXe siècle et en islam. In Conférence publique présentée le 19 mars 1980 à l'institut æcecuménique de recherches théologiques à Tantur, 93-164. Jerusalem: [Éditeur non identifié].

Samir, K. 1982. La culture arabe chrétienne ancienne en interaction avec la pensée arabe musulmane. Islamochristiana 8: 1-35.

Samir, K. 1987. Michel évêque melkite de Damas au 9 siècle: a propos de Bišr al-Sirrī. Orientalia christiana periodica 53: 2: 439-441.

Samir, K. 1989. Religion et culture en Proche-Orient arabe. Islam et Christianisme comme facteurs d'intégration et d'éclatement. Proche-Orient chrétien 39: 251-309.

Samir, K. 1992a. Le traité sur les icțnes d'Abū Qurrah mentionné par Eutychius. Orientalia christiana periodica 58: 461-474.

Samir, K. 1992b. Saint Rawha al-Quraša. Etude d'onomastique arabe et authenticité de sa passion. Le muséon 105: 343-359.

Samn, [?] 2010. Notes on Arab Orthodoxy. http://araborthodoxy.blogspot. com/2010/01/melkites-by-ignatius-dick.html [accessed 22.04.2010].

Sansterre, J. M. 1983. Les moines grecs et orientaux à Rome aux époques byzantine et carolingienne (milieu du VIe s.-fin du IXe s.), vol. 1. Bruxelles: Palais des academies.

Sastre Santos, E. 1997. La vita religiosa nella storia della chiesa e della società. Milano: Ancora.

Sauvaget, J. 1932. Monuments historiques de Damas. Beyrouth: Imprimerie Catholique.

Sauvaget, J. 1967. Châteaux umayyades de Syrie. Revue des études Islamiques 35: $1-49$.

Sauvaire, H. 1894-1896. Description de Damas. Journal Asiatique 3: 192-193.

Schacht, J. 1952. Esquisse d'une histoire du droit musulman. Paris: Edité par Librairie orientale et Américaine Max Besson.

Schadler, P. 2017. John of Damascus and Islam: Christian Heresiology and the Intellectual Background to Earliest Christian-Muslim Relations. The History of Christian-Muslim Relations, vol. 34. Leiden: Brill Publishers. 
Schick, R. 1995. The Christian communities of Palestine from Byzantine to Islamic rule: an historical and archaeological study. Studies in Late Antiquity and Early Islam, vol. 2. Princeton: The Darwin Press.

Schick, R. 1995. The Christian Communities of Palestine to Islamic Rule: A Historical and Archeological Study. Princeton: Darwin Press.

Schlumberger, G. 1890. Un empereur byzantin au dixième siècle: Nicephore Phocas. Paris: Firmin-Didot.

Schmid, K. 1983. Aachen und Jerusalem: Ein Beitrag zur historischen Personenforschung der Karolingerzeit. In Gebetsgedenken und adliges Selbstverständnis im Mittelalter, ed. K. Schmid, 106-126. Michigan: J. Thorbecke.

Schüppel, C. 2019. Nomen elefanti erat Abul Abaz. Über Bedeutung und Deutungen eines diplomatischen Geschenkes, Anwesenheitsnotizanwe senheitsnotiz-Studentische Zeitschrift für Geistes- und Kulturwissensch aften, vol. 10: https://anwesenheitsnotizen.wordpress.com/heft-10-fruehjahr2019/carl-schueppel-nomen-elefanti-erat-abul-abaz/ [accessed 13.10.2020].

Sellers, R. V. 1954. Two Ancient Christologies: A Study in the Christological Thought of the Schools of Alexandria and Antioch in the Early History of Christian Doctrine. London: Society for Promoting Christian knowledge.

Sezgin, F. 1970. Geschichte des arabischen Schrifttums, vol 3: Medizin-Pharmazie-Zoologie-Tierheilkunde bis ca-Buch antiquarisch kaufen. Leiden: Brill.

Shahid, I. 1971. The Martyrs of Nadjran. New Documents. Bruxelles: Societé des Bollandistes.

Shahid, I. 1984. Byzantium and the Arabs in the Fourth Century. Washington: Dumbarton Oaks Research Library and Collection.

Shahid, I. 1988. Byzantium and the Semitic Orient Before the Rise of Islam. London: Variorum Reprints.

Shahid, I. 1989. Byzantium and the Arabs in the Fifth Century. Washington: Dumbarton Oaks Research Library and Collection.

Shahid, I. 1995. Byzantium and the Arabs in the Sixth Century, vol. 2: 1. Washington: Dumbarton Oaks Research Library and Collection.

Sharon, M. 2004. The decisive battles in the Arab Conquest of Syria. Studia Orientalia 101: 297-357.

Shboul, A. 1978. Al-Mas'ūdī and His World: A Muslim Humanist and His Interest in Non-muslims. London: Ithaca Press.

Sirry, M. 2011. The public role of Dhimmīs during 'Abbāsid times. Bulletin of the School of Oriental and African Studies 74: 2: 187-204.

Siwiec, P. 2012. Abū al-'Atāhiya: poeta, błazen, asceta. Kraków: Księgarnia Akademicka.

Slade, D. M. 2019. Patristic exegesis: the myth of the AlexandrianAntiochene schools of interpretation. Socio-Historical Examination of Religion and Ministry 1: 2: 155-176.

Slee, M. 2003. The Church in Antioch in the First Century: Communion and Conflict. London: Sheffield Academic Press.

Sourdel, D. 1959. Le Vizirat abbaside de 749 à 936 (132 à 324 de l'Hegire), vol. 1. Damas: Institut Français de Damas. 


\section{Bibliography}

Sourdel, D. 1960. Le Vizirat abbaside de 749 à 936 (132 à 324 de l'Hegire), vol. 2. Damas: Institut Français de Damas.

Sourdel, D. 1961. La politique religieuse du calife abbaside al-Ma'mūn. Revue des études Islamiques 30: 28-42.

Sourdel, D. 1966. Un pamphlet musulman anonyme d'époque abbaside contre les chrétiens. Revue des études Islamiques 34: 1-33.

Sozomen. 1890. Ecclesiastical History. In Nicene and Post-Nicene Fathers 2.2: Socrates, Sozomenus: Church Histories (Catholic Edition), Ed. Ph. Schaff and H. Wace. New York, NY: Christian Literature Publishing. https://www.newadvent.org/fathers/2602.htm. [accessed 22.10.2020].

Spanneut, M. 1948. Recherches sur les écrits d'Eustache d'Antioche avec une édition nouvelle des fragments dogmatiques et exégétiques. Lille: Fac. Catholiques.

Speck, P. 1990. Ich bin's nicht, Kaiser Konstantin ist es gewesen: die Legenden vom Einfluß des Teufels, des Juden und des Moslem auf den Ikonoklasmus. In Пoıкí $\alpha \beta v \zeta \alpha v \tau \imath v \alpha$, vol. 10. Bonn: Habelt.

Stein, D. 1980. Der Beginn des byzantinische Bilderstreites und seine Entwicklung bis in die $40^{\mathrm{er}}$ Jahre des 8. Jahrhunderts. In Miscellanea Byzantina Monacensia, vol. 25. München: Univ., Diss.

Stellers, R. V. 1953. The Council of Chalcedon. London: S.P.C.K.

Stuz, J. 2019. St Michael of Mar Saba and its Georgian version. In Georgian. Manuscript-International Summer School and Conference, Conference Proceedings, ed. Z. Abashidze and A. Schmidt, 25-30. Tbilisi: Korneli Kekelidze Georgian National Centre of Manuscripts.

Suermann, H. 1985. Die geschichtstheologische Reaktion auf die einallendem Muslime in edessenischen Apokaliptik des, vol. 7. Jahrhundert, Frankfurt: Peter Lang.

Suermann, H. 1987. Der byzantinische Endkaiser bei Pseudo-Methodios. Oriens Christianus 71: 140-155.

Suermann, H. 1995. Muhammad als Vorläufer des Antichristen. In Islam a chrześcijaństwo. Materiały sympozjum Kraków 12-14 IV 1994, ed. A. Zaborski, 321-334. Kraków: Wyd. Naukowe Papieskiej Akademii Teologicznej.

Suermann, H. 2002a. Koptische Texte zur arabischen Eroberung Ägyptens und der Umayyadenherrschaft. Journal of Coptic Studies 4: 167-186.

Suermann, H. 2002b. Maronite historiography and ideology. The Journal of Eastern Christian Studies 54: 3-4: 129-148.

Swanson, M. N. 2001. The martyrdom of 'Abd Al-Masih. In Syrian Christians under Islam: The First Thousand Years, ed. D. R. Thomas, 107-130. Leiden: Brill.

Széll, G. 2013. Justinian and Theodora's peculiar struggle with the monophysites. Acta Antiqua Academiae Scientiarum Hungaricae 52: 1-8.

Szilágyi, K. 2008. Muhammad and the monk: the making of the Christian Bahīrā Legend. Jerusalem Studies in Arabic and Islam 34: 169-214.

Tang, L. 2002. A study of the history of Nestorian Christianity in China and its literature in Chinese: together with a new English translation of the Dunhuang Nestorian documents. In Asian and African Studies, vol. 87. Frankfurt: Peter Lang. 
Tannous, J. 2017. Greek kanons and the Syrian Orthodox liturgy. In Prayer and Worship in Eastern Christianities, 5th to 11th Centuries, ed. B. BittonAshkelony and D. Krueger, 151-180. London-New York: Routledge.

Tchalenko, G. 1956. Villages antiques de la Syrie du Nord. Le massif du Bélus à l'époche romaine, vol. 2. Paris: P. Geuthner.

Ter-Ghewondyan, A. 1976. The Arab Emirates in Bagratid Armenia, Transl. Nina G. Garsoïan. Lisbon: Livraria Bertrand.

Teule, H. G. B. 2007. The veneration of images in the East Syriac tradition. In Die Welt der Götterbilder, ed. B. Groneberg and H. Spieckermann. Beihefte zur Zeitschrit für die alttestamentische Wissenschaft 376: 324-346. Berlin-New York: W. de Gruyter.

Townsend, W. T. 1936. The Henotikon Schism and the Roman Church. The Journal of Religion 16: 78-86.

Treiger, A. 2016. New works by Theodore Abū Qurra preserved under the name of Thaddeus of Edessa. Journal of Eastern Christian Studies 68: $1-51$.

Treiger, A. 2019. Unpublished texts from the Arab Orthodox Tradition (1): on the origin of the term "Melkite" and on the destruction of the Maryamiyya Cathedrale in Damascus. Chronos 29: 7-37.

Treiger, A. 2020. The beginnings of the Graeco-Syro-Arabic Melkite translation movement in Antioch. Scrinium 16: 1-27.

Trimingham, S. J. 1979. Christianity among the Arabs in Pre-Islamic Time. London: Longman.

Tritton, A. S. 1930. The Caliphs and Their Non-Muslim Subjects: A Critical Study of the Covenant of Umar. Oxford: Oxford University Press.

Troupeau, G. 1978. Ibn Taymiyya et sa réfutation d'Eutychius. Bulletin d'Études Orientales 30: 209-220.

Troupeau, G. 1999. Kościoły i chrześcijanie na obszarze Wschodu muzułmańskiego. In Historia chrześcijaństwa. Religia-kultura-polityka, vol. 4: Biskupi, mnisi i cesarze 610-1054, ed. J.-M. Mayer, 319-382. Warszawa: Krupski i S-ka.

Tubach, J. 1993. Michael Syrus. In Biographisch-Bibliographisches Kirchenlexikon, vol. 5: 1467-1471. Herzberg: Verlag Traugott Bautz.

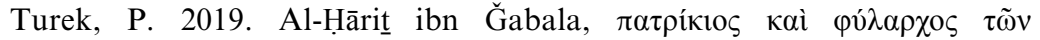

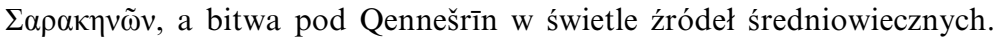
In Rzymianie i barbarzyńcy: religia-polityka-kultura, ed. T. Wolińska, M. Ożóg, K. Kollinger, 73-95. Rzeszów: Wydawnictwo Uniwersytetu Rzeszowskiego.

Turek, P. 2002. Wyrazy obcego pochodzenia w Koranie jako świadectwo arabskich kontaktów językowych i kulturowych z otaczającym światem. In W kręgu cywilizacji Pótksiężyca. 6 Ogólnopolska Konferencja Arabistyczna, Kraków 14-15 maja 2002, ed. B. Michalak-Pikulska, 237-252. Kraków: Wydawnictwo Uniwersytetu Jagiellońskiego.

Turnbull, R. 2019. Arabic Gospel Lectionaries at Sinai. Collectanea Christiana Orientalia 16: 131-166.

Ullmann, M. 1970. Die Medizin im Islam. Handbuch der Orientalistik, vol. 1. Leiden: Brill. 


\section{Bibliography}

Uthemann, K.-H. 2015. Anastasios Sinaites: Byzantinisches Christentum in den ersten Jahrzehnten unter arabischer Herrschaft. Arbeiten zur Kirchengeschichte, vol. 125. Berlin: De Gruyter.

Vailhé, S. 1898. Les écrivains de Mār Sabas. Echos d'Orient 1: 1-11, 33-46.

Vailhé, S. 1908. Antioche, patriarcat grec. In Dictionnaire de théologie catholique, ed. A. Vacant, vol. 1: 1399-1412. Paris: Letouzey et Ané.

Vailhé, S. 1910. Formation du patriarcat de Jérusalem. Echos d'Orient 13: 325-336.

Vailhé, S. 1912. Formation du patriarcat d'Antioche. Echos d'Orient 15: $109-125$.

Valognes, J.-P. 1994. Vie et mort des chrétiens d'Orient. Des origines à nos jours. Paris: Fayard.

van den Broek, R. 1996. Studies in Gnosticism and Alexandrian Christianity. In Nag Hammadi and Manichaean Studies, 39. Leiden: Brill.

van Esbroeck, M. 1984. Jean II à Jérusalem et les cultes de saint Étienne, de la Sainte-Sion et de la Croix. Analecta Bollandiana 102: 99-134.

van Ess, J. 1992. Abd al-Malik and the Dome of the Rock: An Analysis of Some Texts. In Bayt AI-Maqdis: 'Abd ai-Malik's Jerusalem, ed. J. Raby and J. Johns, 89-104. Oxford: Oxford University Press.

Van Roey, A. 1962. Les debuts de l'église Jacobite. In Das Konzil von Chalkedon: Geschichte und Gegenwart, ed. A. Grillmeier and H. Bacht, vol. 2: 339-360. Würzburg: Echter-Verlag.

Varsanyi, O. 2009. The Role of the Intellect in Theodore Abu Qurrah's on the True Religion. Parole de l'Orient 34: 51-60.

Vasiliev, A. A. 1932. Histoire de l'Empire byzantine, vol. 1. Paris: DaupeleyGouverneur.

Vasiliev, A. A. 1956. The Iconoclastic Edict of the Caliph Yazid II, A.D. 721. Dumbarton Oaks Papers 9-10: 25-47.

Vasiliev, A. A. 1968. Byzance et les Arabes. Les relations politiques de Byzance et des Arabes à l'époque de la dynastie macédonienne: (les empereurs Basile I, Léon le Sage et Constantin VII Porphyrogénète) 867-959, vol. 2: 1. Bruxelles: Éditions de l'Institut de Philologie et d'Histoire Orientales.

Vasiliev, A. A. and Honigmann E. 1935. Byzance et les Arabes: von 363 bis 1071 nach griechischen, arabischen, syrischen und armenischen Quellen. Die Ostgrenze des byzantinischen Reiches. Corpus Bruxellense historiae Byzantinae, vol. 3. Bruxelles: Éditions de l'Institut de Philologie et d'Histoire Orientales.

Vellian, J. 1970. The Vicissitudes of the Syro-Malabar Liturgy Down the Centuries: The Malabar Church. Roma: Pontificium Institutum Orientalium Studiorum.

Versteegh, K. 1997. The Arabic Language. New York: Columbia University. Vine, A. S. R. 1937. Nestorian Churches. London: Independent Press.

Violet, B. 1901. Ein zweisprachiges Psalmfragment aus Damascus. Orientalistische Litteratur-Zeitung 4: 384-403, 425-488.

Vööbus, A. 1973. The Origin of the Monophysite Church in Syria and Mesopotamia. Church History 42: 17-26. 
Voorhis, W. J. 1934. John of Damascus on the Moslem Heresy. The Muslim World 24: 391-398.

Vries, W. de 1964. Antiochen und Seleucia-Ctesiphon. Patriarch und Katholikos? In Mélanges Eugène Tisserant, vol. 3: Orient Chrétien, 437-449. Città del Vaticano: Bibl. Apostolica Vaticana.

Weijenberg, R. 1976. Leo der Grosse und Nestorius. Erneuerung der Fragestellung. Augustianum 16: 353-398.

Weil, G. 1848. Geschichte der Chalifen, vol. 2: Die Abbasiden bis zur Einnahme von Bagdad durch die Bujiden, 132-334 d.H. = 749-945 n. Chr. Mannheim: Bassermann, Stuttgart: Metzler.

Weinfurter, S. 2013. Karl der Große. Der heilige Barbar. München, Zürich: Piper.

Weltecke, D. 2003. Die "Beschreibung der Zeiten" von Mor Michael dem Großen (1126-1199). Eine Studie zu ihrem historischen und historiographiegeschichtlichen Kontext. Corpus scriptorum christianorum orientalium, vol. 594. Louvain: Peeters.

Wessel, S. 2004. Cyril of Alexandria and the Nestorian Controversy: The Taking of a Saint and a Heretic. Oxford: Oxford University Press.

Wilkinson, J. 1977. Jerusalem Pilgrims before the Crusades. Warminster: Aris \& Phillips.

Wilmshurst, D. 2011. The Martyred Church: A History of the Church of the East. London: East-West Publishing.

Winkelmann, F. 1979. Ägypten und Byzanz vor der arabischen Eroberung. Byzantinoslavica 40: 161-182.

Winkelmann, F. 2001. Der monenergetisch-monotheletische Streit. In Berliner Byzantinische Studien, vol. 6. Frankfurt am Main: Peter Lang.

Wipszycka, E. 1986. Egipt-ojczyzna mnichów. In Apoftegmaty Ojców Pustyni, ed. M. Starowieyski, 17-47. Warszawa: Akademia Teologii Katolickiej.

Wipszycka, E. 1992. Le nationalisme a-t-il existé dans l'Égypte Byzantine? The Journal of Juristic Papyrology 22: 83-128.

Wipszycka, E. 1994. Kościół w świecie późnego antyku. Warszawa: Wydawnictwa Uniwersytetu Warszawskiego.

Yarbrough, L. 2016. Did 'Umar b. 'Abd al-'Azīz Issue an Edict Concerning Non-Muslim Officials? In Christians and Others in the Umayyad State, ed. A. Borrut and F. M. Donner, 173-206. Chicago: Oriental Institute of the University of Chicago.

Yoshiro, S. 1951. The Nestorian Documents and Relics in China. Tokyo: Toho Bunkwa Gakuin (Academy of Oriental Culture).

Zavagno, L. 2013. Two hegemonies, one island: Cyprus as a "Middle Ground" between the Byzantines and the Arabs (650-850 A.D.). Reti Medievali Rivista 14: 2: 1-32.

Zetterholm, M. 2003. The Formation of Christianity in Antioch: A Socialscientific Approach to the Separation between Judaism and Christianity.

London: Routledge.

Zilio-Grandi, I. 1998. La refutazione della profezia di Muhammad e del miracolo coranico di Qusțā ibn Lūqā. Parole de l'Orient 22: 677-689. 


\section{Index of Geographical Names}

Abaršahr 110

Abyssinia 23

Adana (map 3) 77

Aegyptus Primus 86

Aegyptus Secundus 86

Afghanistan 64

Africa 16, 51, 56, 58, 90, 113, 118

Ahwāz (al-) 109

Aix-la-Chapelle 135, 137

Aleppo 67, 106, 122, 125, 130, 141

Alexandria 2, 4, 5, 7, 8, 9, 10, 11, 14,

$15,19,20,22,23,25,30,31,32,33$,

$35,36,39,40,41,42,43,44,48,45$,

$47,55,57,58,59,75,79,83,85,86$,

$87,88,89,94,118,121,123,124$,

$127,128,130,131,132,164,165133$,

$142,145,146,150,154,160,161$,

162,168

Amanus 64

Amida 76

Anastasiopolis 76

Anazarbos (map 3) 76, 77

Antarados (map 3) 77

Antinoe 86

Antioch 2, 4, 5, 7, 8, 9, 11, 12, 15, 19, $20,21,22,23,24,27,28,29,30,31$, $33,36,37,38,39,44,45,47,52,53$, $59,60,64,66,75,76,77,78,79,80$, $81,82,83,85,90,94,108,109,111$, $117,121,122,123,124,125,126$, $127,128,129,130,132,139,140$, $141,144,145,146,147,160,161$, $163,164,167$

Apamea 60, 76

Aquitaine 135

Arabian Peninsula 37, 63, 70

Arabia 16, 30, 37, 38, 47, 64, 70, 76,105

Arados (map 3) 77
Arca (map 3) 77

Arcadia 86

Arethusa (map 3) 77

Armenia 15, 16, 28, 32, 33, 41, 64, 154

Armenia Minor 15

Arrağān 111

Arsamosata (map 3) 77

Assyria 109

Athens 8, 134

Augustamnica Prima 86

Augustamnica Secunda 86

Aventine Hill 111

'Ayn Šams 56

Baghdad 5, 16, 91, 115, 116, 117, 119, 120, 122, 136, 139, 140, 141, 147, $148,149,152,153,154,163,165$

Balāsagān 110

Balbeek 104

Baqā (al-) 51

Barbalissos (map 3) 77

Barcelona 135

Basilica of the Holy Sepulchre 46, 49, 136, 137, 138

Basilica of St John the Baptist,

Damascus 17, 80, 81, 162

Bassora 60

Batna (map 3) 77

Bayās 65

Bessarabia 26

Bēt Selôk 110

Bêt Zabdē 110

Bethlehem 49, 52, 97, 103

Birtha (map 3) 77

Bosra 76, 116

Botrys (map 3) 77

Bulgaria 26, 126

Būqā 64

Byblos (map 3) 77 
Byzantium 1, 5, 6, 13, 14, 19, 21, 22, $30,33,36,38,42,50,51,53,57,58$, $59,61,63,64,65,79,82,90,99,93$, $91,109,110,114,122,126,133,134$, $135,136,137,139,144,152,154$, $155,158,159$

\section{Cabasa 86}

Caesarea 14, 24, 27, 28, 30, 38, 45, 47, 91

Caesarea Maritima 47

Calabria 26

Calcicos 125

Callinicos (map 3) 77

Cappadocia 24, 26, 34, 49

Carrhae (map 3) 77

Cathedral of Our Lady in

Damascus 122

Central Asia 1, 9, 109, 110, 111, 117, $139,140,141,162,163,165$

\section{Cerdaña 135}

Chalcedon 19, 20, 21, 23, 24, 32, 33, 34, $40,42,44,47,48,75$

Chalcis (map 3) 77

China 31,117

Constantina (map 3) 77

Constantinople 1, 2, 4, 5, 6, 12, 13, 21, $22,23,24,26,30,31,32,33,34,35$, $36,37,40,41,42,43,44,45,47,50$, $51,54,55,75,76,78,79,85,86,87$, $88,93,94,113,114,119,122,124$, $125,126,128,129,130,131,132$, $133,135,139,142,144,145,147$, $149,156,157,158,159,161,162,168$

\section{Cordoba 134, 135}

Corycos (map 3) 77

Cylicia Prima 76

Cylicia Secunda 76

Damascus 17, 52, 53, 54, 60, 64, 76, 78, $80,81,82,90,91,103,104,105,115$, $123,125,127,129,132,139,149$, 161,164

Dār ar-Rūm 139

Dārā 105

Datin 51

Dayr Ayyūb 60

Dead Sea 46, 51

Deïr Kalīlīšū 116

Deïr Karh 116

Deïr Mār Fatyūn 116

Doliche (map 3) 77

Domus Arsicia 114
Edessa 30, 31, 34, 76, 83, 117, 154

Egeas (map 3) 77

Egypt 5, 8, 15, 16, 18, 23, 24, 26, 32, 33, $34,36,37,39,40,41,42,43,44,49$, $56,57,58,59,61,62,63,64,66,68$, $72,73,74,75,86,87,88,89,90,95$, $101,115,118,119,120,130,131$, $132,138,141,143,148,159,160$, 162,164

Emesa (map 3) 77

Ephesus 19, 30, 31, 39, 41, 42

Epiphania (map 3) 77

Ethiopia 23

Euphrates 75, 139, 165

Euphratesia Prima 76

Euphratesia Secunda 76

Europos (map 3) 77

Faramā' (al-) 56

Fuṣtaṭ 133

Ğabal Lukkām 64

Gabala (map 3) 77

Georgia 76

Germanica (map 3) 77

Gerona 135

Golgotha 63

Greater Armenia 33

Ğundīsāpura 109

Ğurğūma 64

Hama 65

Hawrān 52

Heliopolis 56

Herat 110

Hermopolis 14

Hiereia 123

Hieropolis 76

Himyar 38

Hirā (al-) 37

Homs 52, 53, 63, 123, 149

Hulvān 110

India 24, 25, 30, 31

Ingilena (map 3) 77

Irenopolis 141

Izauria 76

Jerusalem 2, 4, 5, 7, 9, 16, 19, 20, 22, $23,24,26,27,35,45,46,47,48,49$, $50,52,54,55,56,59,63,75,76,79$, 91, 92, 93, 94, 95, 96, 97, 99, 103, 104, 106, 108, 118, 121, 123, 124, 
$126,127,128,132,133,135,136$, $137,138,139,142,143,144,145$, $146,156,160,161,162,163,165,168$

Jordan 53

Kāfir 60

Karkā 110

Kāšān 110

Kepha (map 3) 77

Khorasan 109, 111

Kiev 26

Kithara (map 3) 77

Kufa 66, 111, 115, 161

Laodicea 66

Larissa (map 3) 77

Leba 53

Lebanon 37, 59

Leontopolis 86

Libia Prima 86

Libia Secunda 86

Libya 41

Lower Egypt 43

Mādabā 60

Māğid 141

Malabar 25, 26, 30

Mallos (map 3) 77

Mambīğ 10, 57, 127

Mār Sābā, see: monastery of Mār Sābā in Palestine

Mariamme (map 3) 77

Martyropolis (map 3) 77

Marv 110

Mecca 18, 66, 102, 161

Media 110

Medina 18, 58, 102

Mešān 110

Mesopotamia 16, 20, 25, 30, 32, 38, 41, $64,70,73,74,76,109,110,111,149$

Mesopotamia Prima 76

Mesopotamia Secunda 76

The Middle East 1, 4, 5, 6, 9, 17, 21, 22, $26,37,50,51,83,90,101,107,108$, $118,120,121,133,137,148,152,166$

Milan 28

Moldova 26

Monastery Grotto (Grotto Monastery near Homs) 123

Monastery of Mār Sābā (=St Saba) in Palestine 9, 10, 98, 99, 103, 104, 106, $112,137,141,142,143,144,145$, $149,154,165$
Monastery in Wādi Harītūn 138

Monastery of Mār Sābā (=St Saba) in Rome 112, 113, 114

Monastery of Saint Simeon Stylites (=Qal'at Sim 'ān) 97, 164

Monastery of St Euthymius 46, 98, 143

Monastery of St Sheba 46, 138, 149

Monastery of St Theodosius 46, 49, 98,143

Monastery of St Anastasius 98

Monastery of St Catherine in Sinai (=Monastery of Mount Sinai) 9, 49, $98,104,105,141,142,145,149$, 154,165

Monastery of St Chariton 98, 143, 149,165

Monastery of St Euthymius 46, 98, 143

Monastery of St Theodosius 46, 49, 98, 143

Monastery on the Mount of Olives 137, 138

Mopseustia (map 3) 77

Monastery of Mount Sinai see Monastery of St Catherine

Nağrān 37

Naqyūs 57

Nicaea 28, 29, 30, 40, 41, 45, 47, 84, 85, $110,123,124,131,137$

Nicomedia 28, 45

Nikiû 15,57

Nile 15, 40, 56, 90, 141

Nile Delta 15

Nišāpur 111

Nisibis 30,34

Nubia 23

Oksyrynchos 86

Orime (map 3) 77

Ormān 60

Orthosias (map 3) 77

Osroene 76

Ottoman Empire 5

Paderborn 135

Palestina Prima 91

Palestina Secunda 91

Palestina Tertia 91

Palestine 1, 5, 6, 24, 30, 37, 38, 41, 45, 51, 53, 59, 63, 90, 91, 92, 93, 95, 97, $98,99,105,106,108,112,113,118$, $119,138,141,142,145,149,154,166$ Paneas (map 3) 77 
Pārs 110

Pashati 15

Patriarchate of Alexandria 8, 15, 33, $39,40,41,42,43,44,85,86,87,88$, $89,90,130,131,132,133,160,161$, $162,163,164,165$

Patriarchate of Antioch 2, 5, 27, 28, 29 , $30,31,36,37,38,39,75,76,77,78$, $85,121,122,123,124,125,126,127$, $130,140,141,144,145,147,160$, $161,162,163,164,165$

Patriarchate of Constantinople 1, 23, 76, 128, 144, 159

Patriarchate of Jerusalem 9, 45, 46, 47, 48, 49, 54, 91, 92, 93, 94, 99, 133, 134, 135, 136, 137, 143, 160, 161, $162,163,164,165$

Pelusium 56, 86

Pentapolis 41

Perrhe (map 3) 77

Persia 16, 17, 30, 31, 37, 41, 49, 50, 51, 64, 75, 96, 108, 109, 110

Petra 91

Phenicia 76

Phenicia Prima 76

Phenicia Secunda 76

Piccolo Aventino 112

Pompeiopolis (map 3) 77

Ptolemais 86

Ptolemais Hermiu 86

Qal'at Sim ān, see: monastery of Saint Simeon Stylites

Qubbat al-Hazna 90

Qușayr (al-) 143, 146, 165

Ramla (al-) 104

Raphanea (map 3) 77

Raqqa (al-) 104, 125

Rās al- 'Aīn 130

Ray 110

Resafa see Sergiopolis

Rome 1, 4, 5, 6, 10, 22, 23, 24, 27, 28, 30, $33,34,35,36,37,40,43,45,78,79,83$, 93, 94, 109, 112, 113, 114, 123, 124, $125,126,134,137,138,159,162$

Rumagyris 109, 111, 139, 140, 163

Rușāfa, see Sergiopolis

Russia 26

Samsat (map 3) 77

Šapurgān 111

Šāš 111
Scytopolis 91

Sebasta - Sivas (map 3) 77

Seleucia 76

Seleucia Pieria (map 3) 77

Seleucia Trachea (map 3) 77

Seleucia-Ctesiphon 20, 30, 139, 147, 152,164

Seleucobelia (map 3) 77

Septamania 135

Serbia 26

Sergiopolis (=Resafa, Ruṣāfa) 55, 76,150

Šibirgān 111

Sicily 26

South Arabia 37, 105

Southern Syria 52, 63

Spain 17, 67, 135

Sura (map 3) 77

Susiana 110

Syria 1, 5, 8, 16, 18, 20, 24, 25, 26, 30, 32, $34,37,38,39,41,44,51,52,53,54,56$, $59,60,61,63,65,70,73,75,76,78,79$, $81,83,84,85,90,92,93,95,97,99$, $100,101,102,108,110,118,119,125$, $126,138,141,144,149,159,166$

Syria Prima 76

Syria Secunda 76

Tars 76

Tashkent see Šāš

Tebaida 43, 86

Tebaida Prima 86

Tebaida Secunda 86

Teleda 144

Thebaid 41

Theodosiopolis (map 3) 77

Transylvania 26

Tripoli (map 3) 77

Tyr 76

Upper Egypt 23, 43, 57, 87

Urgel 135

Wādi Hูarītūn 138

Yarmūk 53

Yemen 37

Zaragoza 135

Zawyat Razin 15

Zephyros (map 3) 77

Zeugma (map 3) 77 


\section{Index of Persons}

'Abd al-Malik, the prefect of Egypt ( $8^{\text {th }}$ century) $61,63,64,66,79,83$, 88, 90, 92, 93, 103, 106, 161, 162

'Abd ar-Rahman, the caliph of Cordoba from (756-788) 134, 135

'Abdišo' bar Bahrīz, the bishop of Harrān, Mosul and Hazza (first quarter of the $9^{\text {th }}$ century) 148

Abraham III, the patriarch of the Church of the East (905-937) 139,140

Abū al- Atāhiyya, the Arab poet (748-828) 116

Abū Bakr 'Abdallāh b. Abī Quhāfa alSiddīq, the first caliph of Islam (632-634) 96

Abū Bišr Mattā b. Yūnus, Christian master of Al- Fārabī (870-940) 120

Abū Qurra, Theodore, the Melkite bishop and theologian (c. 740-820) $12,83,85,145,148,149,154$, 155,164

Abu $\mathrm{Sa}^{\mathrm{i}} \overline{\mathrm{d}} \mathrm{d}$, the emir of Syria (the forties of the $9^{\text {th }}$ century) 125

Abū Tammām, the Arab poet (804-846) 148

Abū 'Ubayd, the Arab Muslim commander (d. 634) 52

Abū Yūsuf Ya 'qūb b. Ibrāhīm b. Habīb Kūfī (al-), Muslim jurist (c. 729-798) 70, 71, 72, 73, 74, 118

Acatius of Caesarea, the Bishop of Caesarea Palestina (d. 366) 43, 47

Acatius, the patriarch of Constantinople (471-489) 32

Adrian I, the pope, the bishop of Rome (772-795) 134

Agapius I, = Agapius b. Qa'barūn the Melkite patriarch of Antioch,
(953-959[?] or [?]-[?]) 121, 122, 140,167

Agapius, see: Maḥbūb b. Qunsțanțīn al-Mambiğ̄i

Agathon, the Melkite patriarch of Jerusalem (951-964 or 950-964[?]) 134,169

Alexander I of Alexandria, St, the 9th patriarch of Alexandria (c. 318-c.328) 41

Alexander the Great, the king of Macedon (336-323 BC) 39, 109

'Alī b. Abī Țālib, 4th Caliph of the Rashidun Caliphate (656-661) 98

Ambrose of Milan, St, bishop (c. 340-397) 28

Ammonas, St, the Christian ascetic (4th-century) 41

Anastasius I Dicorus, the Byzantine emperor (491-518) 33, 38

Anastasius I of Antioch, The Melkite patriarch of Antioch (561-571 and 593-599) 75

Anastasius II, the Melkite patriarch of Jerusalem (681/693 [?]-705 [706?]) 91, 94, 168

Anastasius II, the Melkite patriarch of Antioch (558-609) 78

Anastasius III, the Melkite patriarch of Antioch (620-628[?]) 78

Anastasius Sinaita, the Greek writer, priest and abbot (d. after 700) 102

Anthony the Great, St, the monk from Egypt (251-356) 41

Anthony monk, (=Rawh al-Qurašī, died 799) 103

Antiochus Strategos, the monk $\left(6^{\text {th }} / 7^{\text {th }}\right.$ centuries) 96 
Apollinarius, the Melkite patriarch of Alexandria (551-570) 43

Arculf, Frankish Bishop of Périgueux, pilgrim to Jerusalem (later $7^{\text {th }}$ century) 92, 93, 162

Arius, the Cyrenaic presbyter (250/ 256-336) 29

Athanasius I, the Melkite patriarch of Jerusalem (929-937) 134, 169

Athanasius III, the Patriarch of Antioch and head of the Syriac Orthodox Church (724-740) 66

St Athanasius (c.295-373) 29

Athanasius of Alexandria, St, the 20th bishop of Alexandria (328-373) 41,42

Athanasius I, "Jacobite" Patriarch of Antioch (595-631) 78

Babylas, St, patriarch of Antioch (237-253) 28

Baḥ̄ira, see: Sergius Bahīrā

Balādurīe 'Ahmad b. Yahyā (al-), the Muslim historian (d. 892) 16, 53, 55

Balawī, Abū Muhammad 'Abdallah b. Muhammad b. 'Umayr Maḥ̂uz alMadini (al-), biographer of Ahmad b. Țūūn ( $10^{\text {th }}$ century) 18,143

Ban̄ 'Amilah, the South Arabian tribe that migrated north 63

Banū Gassān, see Ghassanids

Banū Ğudām, the Arab tribe in the southern Levant 63

Banū Lahm, the Arabian tribal confederacy of the Tanūh 63

Banu Qais, the Arabs tribe around Aleppo 123

Banū Tag̀lib 60, 64, 161

Banū Tanūh, the Christian Arabs tribe around Aleppo 122

Bar Hebraeus, the maphrian of the Syriac Orthodox Church (1264-1286), writer 15, 16, 64, 81, $82,101,140$

Bardas, the regent for emperor Michael III (855-866) 126

Basil the Great, St, the Bishop, Confessor and Doctor of the Church (330-379) 41, 157

Basil, metropolitan of Tire (the forties of the $9^{\text {th }}$ century) 125

Basileus, the Melkite patriarch of
Jerusalem (820-838 or $821-839)$ 133, 168

Bașrī, Abū Sa īd al-Hasan b. Abi 1Hasan (al-), Muslim scholar (642-728) 96

Benjamin I of Alexandria, the Coptic patriarch of Alexandria (623-662) 87,88

Bernard, monk, the pilgrim to Palestine and Egypt (865-886) 138, 139

Booth, Phil, the professor in Eastern Christianity 9, 35, 44

Boudier, Mathilde, the historian 8, 12, 127

Charlemagne, King of the Franks (768-800), Emperor (800-814) 6, 16, $83,118,124,134,135,136,137,138$, 144,165

Charon, Jean François Joseph Charon, see: Karalevskij, Cyrille 7

Cheikho, Louis, the Jesuit scholar (1859-1927) 148

Chosroes II, the Shahanshah of the Sasanian Empire (591-628) 48

Christides, Vassilios, the professor of history 8

Christodulos II, the Melkite patriarch of Jerusalem (966-969) 169

Christodulos I, the Melkite patriarch of Jerusalem (937-951 or 937-950[?]) 134, 169

Christodulos, the Melkite patriarch of Alexandria (907-932) 131, 168

Christopher, the Melkite patriarch of Alexandria (817-841 [848?]) 131, 133, 146, 165

Christopher, the Melkite patriarch of Antioch (960-967) 121, 122, 130, 140,163

Chrysostomos Papadopoulos, the Archbishop of Athens (1923-1938) 8

Clement of Alexandria, the theologian and philosopher (c. 150-c.215) 39

Coates-Stephens, Robert, the historian 10

Codoñer, Juan Signes, the professor of history (born 1964) 9, 85

Conrad, bishop of Constance, the pilgrim to the Holy Land (died 975) 139 


\section{Index of Persons}

Constans II, the Byzantine emperor (641-668) 57, 113

Constantine I the Great, the Roman emperor (306-337) 29, 44, 46

Constantine I, archbishop of the monastery of St Catharine in Sinai ( $9^{\text {th }}$ century) 142

Constantine II, the pope, the bishop of Rome (in fact antipope 767-768) 123

Constantine III (from January to November 641) 44

Constantine IV, the Byzantine emperor (668-685) 65

Constantine V Kopronymos, the Byzantine emperor (741-775) 14, 79, 83, 84, 124, 131

Constantine VII Porphyrogenitus, the Byzantine Emperor (913-959) 14,128

Constantine, pope - the bishop of Rome (708-715) 6

Cosmas I, the Melkite patriarch of Alexandria (727 [731?]-768) 86, 88, $89,124,131,132,162,168$

Cyril of Alexandria, St, the Patriarch of Alexandria (412-444) 42

Cyril of Jerusalem, St, the Bishop of Jerusalem (c. 350-386) 47

Cyril of Scythopolis, the historian of monastic life in Palestine (c. 524-560) 99

Cyrus of Alexandria, the Melkite patriarch of Alexandria (631-642) 9, $35,36,44,57,58,61,79,85,86$, 87,88

Ḍaḥhāq (Bacchus), St, the martyr executed in Jerusalem in 786103

David of Damascus, the Metropolitan Bishop $\left(8 / 9^{\text {th }}\right) 8,12,127$

Decius, the Roman emperor (249-251) 28,40

Demetrius I, St, the Bishop of Alexandria from (188-231) 40, 41

Déroche, Vincent, the professor of history 9

Devreesse, Robert, Georges, the scriptor in the Vatican Library (1894-1978) 75

Dīk, Aggnātịus, the Melkite-Catholic Bishop, Melkite historian (1926-2013) 8
Diocletian, the Roman emperor (284-305) 40, 46

Diodore of Tarsus, the bishop (378-390) 28

Dionysius of Tel-Mahrē, the patriarch of the Syriac Orthodox Church (818-845) 110, 117, 118

Dionysius the Great, St, the patriarch of Alexandria (248-264) 42

Dioscorus I, the Patriarch of Alexandria (444-451) 42, 47

Einhard, the Frankish scholar (c. 775-840) 16, 118, 136

Elias I of Antioch, the Patriarch of Antioch - the Syriac Orthodox Church (709-722) 66, 81, 82

Elias I, the Melkite patriarch of Alexandria (963-1000) 131, 168

Elias I, the Melkite patriarch of Antioch (907-934) 12, 121, 139, 140,167

Elias II, the Melkite patriarch of Jerusalem (770-797 or 787-797[?]) 133,168

Elias III, the Melkite patriarch of Jerusalem (878-907) 127, 134, 138,169

Elias of Heliopolis,, St, the martyr, craftsman (759-779) 103, 104

Elias, the parish priest of Jerusalem ( $9^{\text {th }}$ century) 126

Elias, bishop of Yabrūd $\left(7^{\text {th/ }} 8^{\text {th }}\right.$ centuries) 105

Eudoxia Baiana, the Byzantine Empress (900-901) 128

Eusebius of Caesarea, the historian of Christianity (260/265-339/340) 27 , 28,40

Eusebius of Nicomedia, the Arian priest (d. 341) 29

Eusebius, the titular Melkite patriarch of Alexandria in Constantinople ([?] $8^{\text {th }}$ century) 89

Eustachius, the candidates for patriarch of Antioch (the forties of the $9^{\text {th }}$ century) 125

Eustatius of Antioch, St, the bishop and archbishop of Antioch (c. 320-c.337) 29

Eustatius, the Melkite patriarch of Alexandria (813-817) 131, 146, 168 
Eustratius, the Melkite patriarch of Antioch (969) 121, 167

Euthymius I of Constantinople, the patriarch of Constantinople (907-912) 129

Eutyches Presbyter, the archimandrite at Constantinople (c. 380-c. 456) 32

Eutychius of Alexandria, the Melkite patriarch of Alexandria (933-940) $10,11,36,55,79,80,82,83,88,89$, $122,125,127,128,129,130,131$, $133,143,146,150,165,168$

Evodius, St., the Early Christian bishop of Antioch, succeeding Saint Peter (d. c. 66) 27

Fabia Eudokia, the Empress of the Byzantine Empire (610-612) 44

Fārabī, Muḥammad b. Tarḩān abu Nasr (al-) the early Islamic philosopher and jurist (c. 872-950) 120

Farazdaq, Hammām b. Ġālib (al-), the poet in the Umayyad court (c. 640-c.730) 81

Feodorov, Ioana, the historian 12

Flavian, the patriarch of Constantinople (446-449) 31

Ğāhiz, 'Amr b. Bahr (al-), the Muslim scholar (c. 776-869) 18, 37, 119

Galadza, Daniel, the historian 9

Ğarāğima see Mardaites

George I of Antioch, the Patriarch of Antioch, and head of the Syriac Orthodox Church (758-790) 117,122

George I, the Melkite patriarch of Antioch ([?]-[?] presumably 662-669) 78,167

George II, the Melkite patriarch of Antioch (685 [?]-702 [?] presumably 691-702) 78, 79, 161, 167

George of Bethlehem, St, the martyr, monk of Mār Sābā (d. 852) 103

George Synkellos, the Byzantine historian(d. after 810) 13

George, the Melkite patriarch of Jerusalem (797-807 or [?]-807) 133,168

George the Greek, Ğūraiğ or Georgius ( 7 th century) 148
Ghassanids, Banū Gassān "Sons of Ghassān" - the Christian Arab tribe 51

Ğibrāyīl b. al-Qilā $i$, the Maronite writer (1447-1516) 36

Gibson Margaret Dunlop, the Arabic, and Syriac language scholar (1843-1920) 99

Gignoux, Phillppe, historian (1931-) 110

Graf, Georg, Orientalist of Christian-Arabic literature (1875-1955) 10

Gregory Abū al Farağ, see: Bar Heraeus

Gregory II, the pope, bishop of Rome (715-731) 124

Gregory III, pope - the bishop of Rome (731-741) 6

Griffith, Sidney, Harrison, the professor of Early Christian Studies (born 1938) 8

Haddād, Rašīd, the Melkite historian (born 1929) 8

Hadrian I, the Pope, the Bishop of Rome (772-795) 83, 114, 124

Hadrian, Roman emperor (117-138) 28

Hağğăğ, b. Yūsuf (al-), the governor of the Umayyad Caliphate (c. 661-714) 64

Ḥakam, Abū'l Qāsim 'Abd ar-Raḥman bin 'Abdullah bin 'Abd (al-), the Muslim historian (803-871) 17, 58

Ḥākim b. Amr Allāh (al-), the sixth Fatimid caliph (996-1021) 11

Hālid b. al-Walīd, the Arab Muslim commander (d. 642) 52, 53

Hārit b. Ğabala (al-), ruler of the Arabian state of Gassānids (c. 528-569) 38

Hārūn ar-Rašīd, the fifth Abbasid Caliph (786-809) 5, 118, 136, 137, 142, 143

Heraclius, the Byzantine emperor (610-641) 13, 15, 32, 34, 35, 44, 50, $51,53,54,57,78,87,93,97,108,131$

Hilarion the Great, St, the founder of Palestinian monasticism (291-371) 41

Hišām, b. 'Abd al-Malik (al-), 10th Caliph of the Umayyad Caliphate (724-743) 63, 66, 70, 82, 88 
Honigmann, Ernest, the professor of Byzantine studies (1892-1954) 75

Ḥumaydī, Muḥammad b. Abī Naṣr (al-), The Andalusian historian $\left(11^{\text {th }}\right.$ century) $18,153,164$

Hummarawāyh, the son of Aḥmad b. Ṭūlūn, emir (884-896) 143

Ibn Abī Ușaibi a, the Arab physician (1194-1270) 146

Ibn al-Ațīr, 'Izz al-Dīn Abū al-Ḥasan 'Alī, the Muslim historian and biographer (1160-1233) 16, 52, 55,118

Ibn al-Ḥakam, Muhammad b. Marwān, the Umayyad prince (d. 720) 64

Ibn al-Ḩammār, al-Ḥasan b. Suwār, the philosopher (943-1020) 120

Ibn al-Rūmī, Abū al-Hasan Alī b. alAbbās b. Ğūraiğ (836-896) 148

Ibn al-Ṭayyib, Abū al-Farağ 'Abdallāh, the Christian priest (d. 1043) 120

Ibn 'Asākir (1105-1175), the Sunni Islamic scholar, and historian 17, 80

Ibn Ğarrāḥ, 'Alī b. 'İsā b. Dā'ūd (al-), the Persian official of the Abbasid Caliphate (859-946) 140

Ibn Hualdūn, Walī ad-Dīn 'Abd arRaḥmān b. Muḥammad al-Ḥaḍramī, the sociologist, philosopher and historian (1332-1406) 59, 118

Ibn Ḥanbal, Abū 'Abdallāh Aḥmad b. Muhammad b. Ḥanbal al-Šaibānī, the Muslim jurist (780-855) 118

Ibn Hindū, 'Alī b. al-Husayn, the Persian Muslim philosopher (d. 1018) 120

Ibn Šaddād, the Arabic scholar (died 1285) 147

Ibn Sallām, Abū 'Ubayd al-Qāsim, the Arab philologist (c. 770-838) 73

Ibn Sanğala, Abū al-Ḥasan Sa īd b. Amr, the secretary of Caliph $\left(10^{\text {th }}\right.$ century) 119

Ibn Sīnā, Abū Alī Huusayn b. 'Abdallāh, the philosopher (980-1037) 120

Ibn Šu'ayb, Muhammad the emir of Crete (895-910) 158

Ibn Šurayh, Abū 'Amr, the Christian official ( $10^{\text {th }}$ century) 119
Ibrāhīm b. Yūḥanna, the Byzantine bureaucrat from Antioch (10th/11th century) $12,111,140,141$

Ignatios of Constantinople, St, the patriarch of Constantinople (847-858; 867-877) 126, 139

Ignatius, St, bishop of Antioch (70-107) 27, 28

Irena of Athens, the empress of the Byzantine Empire (752-803) 134

Isaac, the Melkite patriarch of Alexandria (941-954) 131, 168

Jacob Baradaeus, the Bishop of Edessa of the Syriac Orthodox Church (543-578) 2, 32, 34

Jacob of Edessa, the Syrian Orthodox scholar (c. 640-708) 102, 108

James the Just, "the brother of Jesus" (d. c. 62/69) 24, 48

Job, the Melkite patriarch of Alexandria (954-960) 131, 168

Job, the Melkite patriarch of Antioch (813/814-844/845) 121, 122, 124, $146,147,163,164,167$

John Chrysostom, St, the early Church Father (c. 350-407) 28, 157

John III, the Melkite patriarch of Antioch (997-1021) 76

John Malalas, the Greek chronicler from Antioch (491-578) 14

John of Damascus, St, the Christian monk, priest, and apologist (c. 675-749) 8, 12, 14, 83, 84, 85, 94, $105,106,107,109,154,155,162$

John of Ephesus, leader of the early Syriac Orthodox Church (c. 507-588) 109

John of Nikiû, the Coptic bishop of Nikiû, and historian ( $7^{\text {th }}$ century) 15 , $35,36,44,58,87,109$

John of Persia, participant of the council of Nicaea $\left(4^{\text {th }}\right) 110$

John of Philadelphia, the Patriarchal Vicar of Jerusalem (after 649-?) 91, 94, 168

John Philoponus, the Byzantine Greek philologist, commentator (c. 490-c. 570) 89,162

John the Merciful, St, the Melkite patriarch of Alexandria (c. 606c.616) 87 
John V, pope - the bishop of Rome (685-686) 6

John V, the Melkite patriarch of Jerusalem (= John VI [?] 705 [706]-735) 91, 94, 95, 161, 168

John VI, the Melkite patriarch of Jerusalem (839-843 or 838-842) 133, 169

John VII, the Melkite patriarch of Jerusalem (964-966) 134, 163, 169

John VIII, the pope, the bishop of Rome (872-882) 138

John XXII, the pope, the bishop of Rome (1316-1334) 141

John, the Melkite bishop (catholicos?) of Baghdad (10 ${ }^{\text {th }}$ century) 140,141

Joseph, representative of the patriarch of Alexandria ( $9^{\text {th }}$ century) 132

Justin, the Byzantine emperor (518-527) 43

Justinian I the Great, the Byzantine emperor (527-565) 20, 21, 32, 33, 43,47

Justinian II Rinotmetos, the Byzantine emperor (685-695, 705-711) 63, 157

Karalevskij, Cyrille, the French Catholic clergyman of the oriental rite (1878-1959) 7

Khosrow I, Shahanshah of the Sasanian Empire (531-579) 109

Kilpatrick, Hilary, the historian (born 1956) 9

Kinān̄̄, 'Abd al-Malik b. Ab̆gar (al-), the medical expert $\left(7^{\text {th }} / 8^{\text {th }}\right.$ centuries) 89

Kutubī, Abū 'Abd Allāh b. Muhammad b. Šākir al-Kutubī (1287[?] or 1397[?]-1363), the Syrian historian and biographer 111

Lammens, Henri, the Orientalist, historian and Jesuit (1862-1937) 70

Lamoreaux, John, the professor of the history 12,104

Leeming, Kate, the historian (Arab Christianity) 9, 145

Leo I the Great, St, Pope, bishop of Rome (440-461) 31, 32, 40, 48, 107, 124

Leo I, the Byzantine emperor (457-474) 20
Leo III, the Byzantine emperor (717-741) 79, 83, 84, 157

Leo III, the pope - the bishop of Rome (795-816) 134, 138

Leo IX, the pope - the bishop of Rome (1049-1054)

Leo $\mathrm{V}$ the Armenian, the Byzantine emperor (813-820) 13, 124

Leo VI the Philosopher, the Byzantine Emperor (886-912) 13, 14, 127, 128, $129,132,164$

Leontius of Byzantium, theologian (485-543) 154

Leontius of Damascus, the monk from the monastery of Mar Saba ( $9^{\text {th }}$ century) 143

Leontius, representative of the patriarch of Alexandria ( $9^{\text {th }}$ century) 132

Leontius I, the Melkite patriarch of Jerusalem (912-929) 134, 169

Leontius of Cella Nova, the monk $\left(7^{\text {th }}\right.$ century) 114

Levy-Rubin, Mika, the professor of history 9

Louis the Pious, the Emperor of the Carolingian Empire (814-840) 138

Lucian of Antioch, St, the martyr (c. 240-312) 28

Macarius of Egypt, St, the monk from Egypt (300-391) 41

Macarius, the Melkite patriarch of Antioch ([?]-681 presumably 669-681) 78, 167

Macedonius, the Melkite patriarch of Antioch (639/640-649 [?] 662[?]) 78, 167

Maḥbūb b. Qunsțanțīn al-Mambiğ̄i, the Melkite bishop of Mambī̌ $\breve{g}$, writer and historian (d. 945) 2, 10, 12, 57, 133, 146, 147, 164

Mahdī, Abū 'Abd Allāh Muḥammad b. 'Abd Allāh al-Manșūr b. Muhammad b. 'Alī (al-), 3rd Caliph of the Abbasid Caliphate (775-785) 122,123

Mâlik b. Anas, the Muslim theologian and lawyer (711-795) 17

Malik, b. Marwān 'Abd (al-), 5th Caliph of the Umayyad Caliphate (685-705) 61, 64, 79, 90, 92, 93, 103, $106,161,162$ 
Malik, 'Abd (al-), prefect of Egypt $\left(8^{\text {th }}\right) 88$

Ma'mūn, Abū al-'Abbās 'Abd Allāh (al-), 7th Caliph of the Abbasid Caliphate (813-833) 118, 163

Manșūr b. Sarğūn, the priest of Damascus ( $7^{\text {th }}$ century) 105

Manșūr, Abū Ğa 'far 'Abd Allāh b. Muḥammad b. 'Alī (al-), 2nd Caliph of the Abbasid Caliphate (754-775) $116,117,122,163$

Manuel I Comnenos, the Byzantine emperor (1143-1180) 15

Manuel, the command of General of Armenian origin ( 7 th century) 58

Maqrīzī, Taqī al-Dīn Abū al- 'Abbās Ahmad b. 'Alī (al-), the prominent historian (1364-1442) 118

Marcian, the Roman emperor of the East from (450-457) 42

Mardaites, The Christians of the Nur Mountains following either Miaphysitism or Monothelitism 64,65

Mārī b. Sulāymān, "Nestorian" writer ( $13^{\text {th }}$ century) $16,111,119,140,163$

Mark the Evangelist, the founder (?) of the Church of Alexandria (5-68) 39

Martin I, the Pope, bishop of Rome (649-655) 79, 94, 112, 113, 162

Martina, the Empress of the Byzantine Empire, (613-641) 44, 50

Marwān II, bn Muḥammad b. Marwān b. al-Hakam, the last Caliph of the Umayyad Caliphate (744-750) 83

Marwazīi, Ibrāhīm (al-), Christian master of Al- Fārabī $\left(10^{\text {th }}\right.$ century) 120

Masīḥ̄i, Abū Sahl 'Isā b. Yaḥyā (al-) the Christian philosopher (970-1010) 120

Mas 'ūdī, Abu al-Hasan 'Alī b. alHusain (al-), the Arab historian, geographer and traveler (c. 896-957) $17,64,147$

Maxim the Confessor, St, the Christian monk, theologian, and scholar (c. 580-662) 21, 107

Michael I, the Coptic patriarch of Alexandria (743-767) 88, 89

Michael I, the Melkite patriarch of Alexandria (860-870) 131, 132, 168
Michael II the Amorian, the Byzantine emperor (820-829) 122, 147

Michael II, the Melkite patriarch of Alexandria (870-903) 127, 131, 132, 168

Michael the Syrian, the historian, the patriarch of the Syriac Orthodox Church (1166-1199) 15, 16, 60, 63, $64,66,67,75,81,83,118,122,123$, 125,147

Michael, St, the martyr and monk from the monastery of Mār Sābā 103

Modestus of Jerusalem, St, the Melkite patriarch of Jerusalem (632-634) 49

Monferrer-Sala, Juan, Pedro, the professor of Arabic and Islamic Studies 9

Mu'ad martyr, the Taglib leader $\left(8^{\text {th }}\right.$ century) 64

Mu'āwiya b. Abī Sufyān, 1st Caliph of the Umayyad Caliphate (661-680) $56,61,63,65$

Muhammad, the founder of Islam (c. 570-632) 18, 51, 57

Mundir III (al-), Lahmid king (c. 505-554) 38

Muqtadir, Abū al-Faḍl (al-), 18th Caliph of the Abbasid Caliphate (908-929/932) 122, 158

Mu'tamid, Abū al-'Abbās Aḥmad (al-), 15th Caliph of the Abbasid Caliphate (870-892) 127

Mu'tașim, Abū Isḥāq Muḥammad b.Hārūn al-Rašīd (al-), (833-842) $118,122,125$

Mutawakkil, Abū al-Faḍl Ğa far b. Muhammad (al-), 10th Caliph of the Abbasid Caliphate (847-861) 74, 116, 117, 118, 119, 121, 140, 163

Muțī', Abū al-Qāsim al-Faḍl b. alMuqtadir (al-), 23rd Caliph of the Abbasid Caliphate (946-974) 130, 157

Muwaffaq, Abū Aḥmad Ṭalha b. Ğa far (al-), the regent, the Abbasid prince and military leader (870-891) 128

Nadīm, Abū al-Farağ Muhammad b. Abī Ya'qūb b. Isḥāq al-Warrāq b. Ishāq (al-), Muslim bibliographer (d. c. 995$) 148$ 
Nașrallāh, Yūsuf, the Melkite historian (1911-1993) 8

Nero, Claudius Caesar Augustus Germanicus, the fifth emperor of Rome (54-68) 27, 28, 40

Nestorius, the Archbishop of Constantinople (428-431) 2, 29, 30,31

Nicolas I Mystikos, the patriarch of Constantinople (901-907; 912-915) $128,129,158$

Nicolas I the Great, the pope - the bishop of Rome (858-867) 40, 126,131

Nicolas I, the Melkite patriarch of Antioch (847-867 or 846-868[?]) $121,125,167$

Nikephoros II Phocas, the Byzantine emperor (963-969) 157

Nikephoros Uranus, the Antiochian prince (999-1006) 141

Nikephoros I of Constantinople, the Patriarch of Constantinople (806-815) 13, 124

Nikon of the Black Mountain, the Byzantine monk (c. 1025-1105) 141

Onopsus, the titular Melkite patriarch of Alexandria in Constantinople ([?] $8^{\text {th }}$ century) $86,89,168$

Origen, the early Christian scholar (c.184-c.253) 39, 42

Pachomios, St, the martyr, caliph's cousin (died $8^{\text {th }}$ century) 103

Pachomius the Great, St, the founder of Christian cenobitic monasticism (c. 292-348)

Parry, Ken, the professor of history 9

Paul I, St, the Pope, the Bishop of Rome (757-767)

Paul I, the pope, the bishop of Rome (757-767) 83, 123, 134

Paul of Samosata, the bishop (260-270) 28, 29

Paul of Thebes, St, the first Hermit (c. 227 - c. 341 ) 41

Paul the Apostle, St, the Christian apostle (5-c.64/67) 27, 34

Pepin the Short, the was King of the Franks (751-768) 123, 134, 135

Peter Capitolias, St, the martyr during the reign of Al-Walid I (d. 715
Peter III of Alexandria, the patriarch of Alexandria (477-489) 32

Peter III, the Melkite patriarch of Antioch Peter III (1052-1056) 111

Peter III=Peter IV [?], the Melkite patriarch of Alexandria (643/ 644-651 or 642-651) $85,86,88$, 161,168

Peter IV=Peter V, the titular Melkite patriarch of Alexandria in Constantinople ([?] $8^{\text {th }}$ century) 86 , 89, 168

Peter of Capitolias, St, the martyr, bishop of Bosra (died 715) 103

Peter of Damascus, St, the martyr (c. 675-c. 749) 105

Peter V = Peter VI, the titular Melkite patriarch of Alexandria in Constantinople ([?] $8^{\text {th }}$ century) 86, 168

Peter, St., one of the first leaders of the early Church (d. between 64-68) 27, 39

Peter, the martyr, Melkite bishop of Damascus ( $8^{\text {th }}$ century) 82

Philip the Arab, the Roman Emperor (244-249) 28

Photios I of Constantinople, the patriarch of Constantinople (858-867 and 877-886) 121, 125, $126,131,132,158,164$

Politianos, the Melkite patriarch of Alexandria (768-813) 131, 132, 145, 146, 165,168

Procopius of Caesarea, the scholar from Palaestina Prima (c. 500 - after 565) 14, 20, 38, 109

Proterius of Alexandria, the Patriarch of Alexandria (450-457) 42, 43

Qasrī, Hālid b. 'Abdallāh (al-), the governor of Iraq (724-738) 66, 111,161

Qusțā b. Lūqā al-Ba 'labakkī, the Syriac Melkite physician (820-912) 146, 147, 164

Rāộ̄, Abū al-'Abbās Aḥmad (Muhammad) b. al-Muqtadir (al-), 20th Caliph of the Abbasid Caliphate (934-940) 119

Rawh al-Qurašī (Anthony), St, the martyr (died 799) 103 
Rāzī, Bakr Muhammad b. Zakarīyā (al-), the physician, alchemist, philosopher (854-925) 120

Romanos, St, the martyr, Byzantine monk (d. 780) 103

Sabaites, monks of the monastery of monastery of Mār Sābā in Rome 6, 112,113

Safāḥ, Abū al-'Abbās, (al-), 1st Caliph of the Abbasid Caliphate (749-754) 116,122

Šāfi 'ī al-Dimašqī, 'Alī b. al-Ḥasan b. Hibat Allāh b. 'Abd Allāh b. alHusain Abū 'l-Qāsim (al-) See Ibn 'Asākir

Šăfi '̄i, Muhammad b. Idrīs (al-), the Muslim theologian and lawyer (767-820) 17

Sahas, Daniel, the professor of history (born 1940) 9

Sahmī, 'Amr b. al-'Āṣ (al-), the Arab commander in Egypt (d. c. 573-664) $56,57,58,62,85,88$

Sahner, Christian, the professor of history 9, 104

Sa'īd b. Bitrīq, see: Eutychius, the Melkite patriarch of Alexandria (933-940)

Salomon, the Melkite patriarch of Jerusalem (855-865 or $860-865[?])$ 134, 169

Șāmit, Ubadah b. (al-), the companion of Muhammad (d. 665) 57

Šāšs̄î, Ismā īl al-Qaffāl al-Kabīr (al-), the shāfi lawyer (died 976) 157

Sāwīrus b. al-Muqqaffa', See Severus

Sayf ad-Dawla, the founder of the Emirate of Aleppo (944-967) 130,140

Sebastian, the Melkite patriarch of Antioch (687-690) 78, 79, 167

Selim I, the Sultan of the Ottoman Empire (1512-1520) 5

Septimius Severus, the Roman emperor (193-211) 40

Sergius Bahīrā, the legendary (semi-legendary) Arab Nestorian monk ( $7^{\text {th }}$ century) 100

Sergius dux, The Byzantine $d u x$ and candidatus (The Battle of Datin) 51
Sergius I, the Melkite patriarch of Jerusalem (842-844 or 843-859[?]) 133, 169

Sergius I, the patriarch of Constantinople (610-638) 34, 35, 44,113

Sergius I, the pope - the bishop of Rome (687-701) 6

Sergius II, the Melkite patriarch of Jerusalem (908-911 or 907-911) 134, 169

Sergius III, the pope, the bishop of Rome (904-911) 128

Sergius of Jaffa, bishop, the supporter of Monotheletism ( $7^{\text {th }}$ century) 94

Serikof, Nikolaj, the historian 12

Severus the Great of Antioch, the Patriarch of Antioch and head of the Syriac Orthodox Church (512-538) $33,66,81$

Severus, the Coptic Orthodox Bishop of of Hermopolis (955-987), and historian 14, 15, 40, 64, 66, 87, 88, 89

Silvanus, The bishop in the kingdom of Himyar ( $6^{\text {th }}$ century) 38

Simeon I of Antioch, the Melkite patriarch of Antioch (890-907) 121, $127,128,168$

Socrates Scholasticus, the Christian church historian (c. 380 - after 439) 13

Sophronius I, the Melkite patriarch of Alexandria (841-860 [848-860?]) $131,146,168$

Sophronius II, the Melkite patriarch of Alexandria (941) 131, 168

Sophronius of Jerusalem, the Melkite patriarch of Jerusalem (634-638) 9, $35,52,54,56,91,94,97,156,168$

Sozomenus, Salminius Hermias, the a Roman lawyer and historian (c. 400-c.450) 13

Stephen of Dora, the bishop of Dora (VIIth century) the Patriarchal vicar of Jerusalem (d. 649-?) 91, 94

Stephen II, the pope, the bishop of Rome (752-757) 134

Stephen III (or IV), the Melkite patriarch of Antioch (742/743-744/ 745 presumably 743-744) 78, 82, 83, 161,167 
Stephen IV, the Melkite patriarch of Antioch $(870$ - one day pontificate [?]) $121,127,167$

Stephen of Mār Sābā, St, monk (c. 725-c.794) 142

Sulaymān, b. 'Abd al-Malik, the seventh Umayyad caliph (715-717) 65,161

Șūī̄, Abū Bakr Muḥammad b. Yaḥyā b. al-'Abbās (al-), the Muslim historian (c. 870-c. 948) 18, 119

Swanson, Mark, the Christian-Muslim relations researcher 12, 104

Szilágyi, Krisztina, the Christian-Muslim relations researcher 12

Ta 'âlibī, Abū Manșūr (al-), the anthologist and collector of epigrams (961-1038) 18, 142

Tabarī, Muḥammad b. Ğarīr (al-), the scholar, historian (839-923) 17, 52, $55,56,63,72,74,118$

Tağlibīi, Abū al Ḥasan 'Alī b. Abī al Haiğā' Saif ad-Daula (al-), the Hamdanid prince (916-967) 122

Tag̀libī, al-Ahțal (al-), The Christian poet $(\mathrm{c} .640-\mathrm{d}$. before 710$) 60$

Taglibits, the Christian clan Banū Taglib

Takrītī, Habīb b. Hidma Abū Rāìța (al-), the "Jacobite" polemist (died c. 830) 148

Ṭarsūsī, Damyānah, the Tulunid partisan (died 924) 158

Theocharistus, the Melkite patriarch of Antioch (944-948) 121, 130, 167

Theodora, the Empress of the Byzantine Empire (527-548) 33, 43

Theodore Abu Qurra, the Melkite theologian (c. 740-820) 12, 83, 85, $145,154,155,162,164$

Theodore Graptos, St, monk of Mār Sābā (died c. 844) 144

Theodore I of Antioch, the Melkite patriarch of Antioch (750/751-773/ 774) $121,122,167$

Theodore I of Jerusalem, the Melkite patriarch of Jerusalem (745 [752?]-770) 91, 95, 123, 124, 133, 168

Theodore I, the pope, the bishop Rome (642-649) 94, 112, 113
Theodore II, the titular Melkite patriarch of Alexandria in Constantinople ([?] $8^{\text {th }}$ century) 86 , 89, 168

Theodore Intruder, the Melkite patriarch of Jerusalem $\left(8^{\text {th }}\right.$ century [?]-[?]) 133, 137, 168

Theodore of Mopsuestia, the Bishop of Mopsuestia (392-428) 31

Theodore of Pharan, bishop of Pharan ( $7^{\text {th }}$ century) 79

Theodore the Melkite bishop of Jerusalem ( $7^{\text {th }}$ century) 94

Theodoret of Cyrus, the bishop of Cyrus (423-457) 13

Theodoretus, the Melkite patriarch of Antioch (before 787-[?] or 781-812[?]) 117, 121, 122, 163, 167

Theodorus Lector, the lector at the Hagia Sophia (6 ${ }^{\text {th }}$ century) 13

Theodosius I, the Melkite patriarch of Antioch (870-890) 121, 126, 127, $128,132,167$

Theodosius I, the Roman emperor (379-395) 80

Theodosius II, the Melkite patriarch of Antioch (936-943) 121, 129, 130, 167

Theodosius II, the Roman emperor of the East (402-450) 30, 48

Theodosius of Jerusalem, the "Monophysite" bishop of Jerusalem (451-453) 47

Theodosius, the Melkite patriarch of Jerusalem (862-878 or before 867878 [?]) 134, 139, 169

Theophanes the Confessor, the monk and chronicler (c. 758-817) 13, 18, 20, 50, 54, 57, 64, 66, 79, 82, 83, 86, $94,100,105,117,122,123,142,143$, $147,155,157$

Theophanes Graptos, St, monk of Mār Sābā (died c. 845) 144

Theophanes, the Melkite patriarch of Antioch (681-[?] presumably 681-684) 78, 79, 167

Theophano Martinakia, St, the Byzantine Empress (886-893) 128

Theophilus, St from Egypt (385-412) 42

Theophilus, St, (the $2^{\text {nd }}$ century) 28

Theophilus, the Byzantine Emperor (829-842) 146 


\section{Index of Persons}

Theophylact b. Qānbara, the Melkite patriarch of Antioch (744-750) 78, 83, 167

Theophylact Lekapenos, the patriarch of Constantinople (933-956) 130

Theophylact, the titular Melkite patriarch of Alexandria in Constantinople ([?] $8^{\text {th }}$ century) 86, 168

Thomas I, the Melkite patriarch of Jerusalem (807-820 or 808-821) 133, 138,168

Thomas, monk, representative of the patriarch of Alexandria $\left(8^{\text {th }} / 9^{\text {th }}\right.$ centuries) 131

Thomas, the Melkite patriarch of Antioch ([?]-685 [?]) 78, 79, 167

Thomas, the metropolitan bishop of Tyre ( $9^{\text {th }}$ century) 126,149

Thomas, the usurper in $821\left(9^{\text {th }}\right.$ century) 122,147

Timothy I of Seleucia-Ctesiphon, the Patriarch of the Church of the East (780-823) 20, 147, 152, 164

Timothy III Salophakiolos, the Melkite patriarch of Alexandria (460-475; 477-481) 20

Trajan the Patrician, the Byzantine historian ( $7 / 8^{\text {th }}$ century) 13

Trajan, the Roman emperor (98-117) 27,28

Treiger, Alexander, the professor of Religious Studies 9

Ṭūlūn, Ahmad ibn, founder of the Tulunid dynasty (868-884) 18, 119, 126,143

Turnbull, Robert, the historian (Arab Christianity) 9, 145

'Umar I, Abū Hafṣ b. al-Hatțāa, 2nd Caliph of the Rashidun Caliphate (634-644) 15, 54, 56, 58, 59, 60, 65, $70,71,74,75$

'Umar II, b. 'Abd al-'Azīz, 8th Caliph of the Umayyad Caliphate (717-720) $9,65,69,72,81,84,95,96,106$, 157,161

Valerian, the Roman emperor (153-260) 40
Walīd I, b. 'Abd al-Malik the sixth Umayyad caliph (705-715) 17, 63, $64,65,80,81,105$

Walīd II b. Yazìd (al-), 11th Caliph of the Umayyad Caliphate (743-744) 161,162

Wāqidī, 'Umar b. Wāqid (al-), the an early Muslim historian and biographer (c. 747-823) 55

Warrāq, Abū 'Īsā Muhammad b. Hārūn (al-), the Arab critic of religion (died 861) 17, 152

Wātiq, Abū Ğa far Hārūn b. alMu'tașim (al-), 9th Caliph of the Abbasid Caliphate (842-847) 118,125

Weil Gustav, the German orientalist (1808-1889) 115

William of Tyre, the archbishop of Tyre (1127-1135) 36

Willibald, St, the bishop of Eichstätt, pilgrim to Jerusalem (c. $700-$ c.787) 93

Yahyā al-Anțakī see Yahyā b. Sa 'īd of Antioch

Yahyā al-Nahawī see John Philoponus

Yahyā b. Ādam, The Muslim scholar (d. 818) 73

Yahyā b. 'Ad̄̄i, the Christian philosopher (893-974) 120

Yahyā b. Sa'īd of Antioch, the Melkite Christian historian (985-1066) 11, 130,140

Ya'qob II, the Patriarch of the Church of the East (753-773) 117

Yāqūt, Šihāb ad-Dīn Abū 'Abd Allāh b. Yàqūt al-Hamawī ar-Rūmī (al-), the Arabic geographer (1179-1229) 142

Yarbrough, Luke, the historian 9

Yazīd b. Abī Sufyān, the leading Arab general (d. 639) 51, 52

Yazīd II, b. 'Abd al-Malik, 9th Caliph of the Umayyad Caliphate (720-724) $66,81,83,84,161$

Yūhannā b. Haylān, the Nestorian Christian monk, master of Al-Fārabī ( $10^{\text {th }}$ century) 120 
Zacharias, the Melkite patriarch of Jerusalem (609-632) 49, 96

Zacharias, Father, the envoy of Charlemagne to East $\left(8^{\text {th }} / 9^{\text {th }}\right.$ century) 137

Zeno, the Roman emperor of the East (474-475) 32, 43
Zenobia, the Queen of Palmyra (260-274) 28

Zoe Karbonopsina, the Byzantine Empress (906-920) 128

Zoe Zaoutzaina, the Byzantine Empress (898-899) 128 


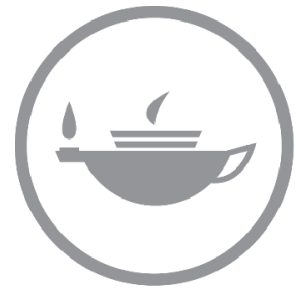

Taylor \& Francis
Taylor \& Francis Group http://taylorandfrancis.com 